\title{
A SUBSOLAGEM NO CONTROLE DA COMPACTACÃO DO SOLO NA CANA-SOCA (Saccharum spp) VARIEDADE CB 41-76 E SEUS EFEITOS NO RENDIMENTO AGRÍCOLA E NO SISTEMA RADICULAR
}

JOSÉ FERNANDES

Engenhelro Agrônomo

Tose Apresentada à Escola Superior de Agricultura "Luiz de Queiroz", da Universidade de São Paulo, para obtenção do grau de Mestre em Solos e Nutrição de Plantas.

$P|R A C| C A B A$

Estado de São Paulo - Brasil

Outubro, 1979 
A minha esposa clara, Ao meu filho Cesar Domingos, por entenderem minhas preocupações durante algum tempo, 


\section{A G R A D E C I ME N T O S}

- Ao professor Dr. Klaus Reichardt, pelo apoio e orientação na elaboração deste trabalho.

- Ao professor Or. Humberto de Campos e à Eng - Agr - Lucila olivetto Maranhão, pelas sugestões e contribuições nos as pectos da estatística.

- Aos Engos Agros Daniel Camposilvan e Victōrio Laerte Furlani Néto pela valiosa colaboração durante todo o andamento dos trabalhos de campo.

- A Direção do CENA - Centro de Energia Nuclear na Agricultu ra - Piracicaba-SP, por permitir o uso do laboratório nas análises de densidade do solo.

- A Diretoria da Usina Tamoio, em particular ao Eng? Agrọ Re nato Agujara pela contribuição sob a forma de material e mão de obra para a consecussão do trabalho.

- As bibliotecárias da Coordenadoria Regional Sul do Planalsucar. Ana Maria Zaia Gheller e Sueli Aparecida Metzker, pela ajuda e órientação na revisão bibliográfica.

- A senhorita Angela Maria Moraes pela dedicação nos serviços de datilografia.

- Ao Engo Agro Dr. Gilberto Miller Azzi, como chefe, incenti vador e amigo, com minhas homenagens. 


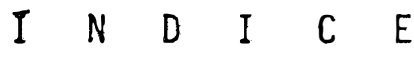

Página

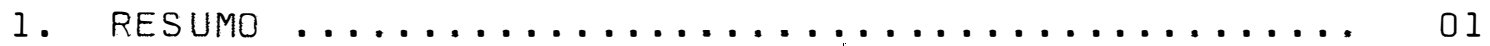

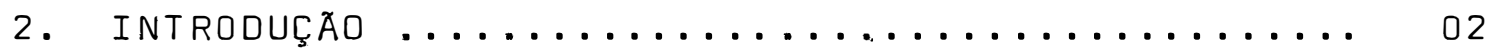

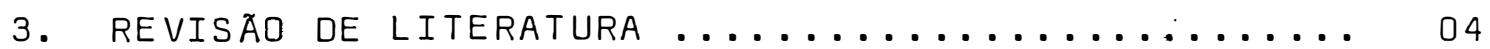

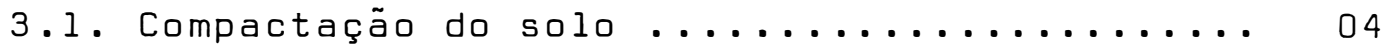

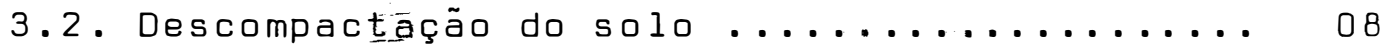

3.3. Relação sō̃o - sistema radicular ......... 09

3.4. Efeitos da compactação do solo no sistema rá dicular de algumas culturas ............. 10

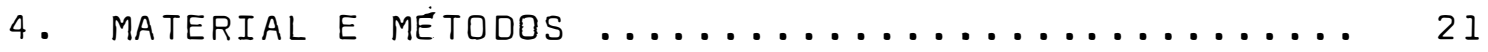

4.1. Area do Experimento .................... 21

4.1 .1 Localização ................... 21

4.1.2. Condições climáticas regionais ..... 22

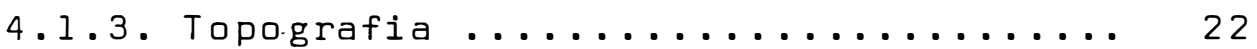

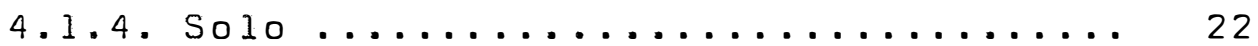

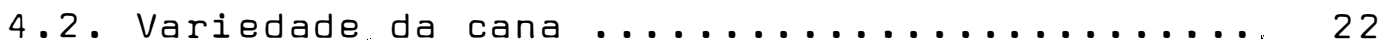

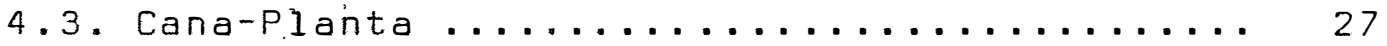

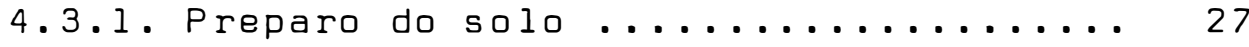

4.3.2. Plantio e tratos culturais ........ 27

4.3.3. Primeiro corte - Produção .......... 28

4.3.4. Transporte da cana-planta ......... 31

4.4. Delineamento experimental ................. 31

4.4 .1 . Tratamentos .....................31

4.4.1.1. Tratamentos de compactação. 32

4.4.1.2. Tratamentos de descompactação $\ldots \ldots \ldots \ldots \ldots \ldots \ldots \ldots \ldots \ldots \ldots \ldots \ldots$

4.4 .2 . Repetições .................... 32

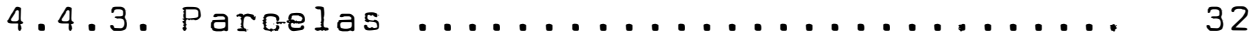

4.4 .4 . Esquema de Campo ............. 33 
Página

4.4.5. Análises estatísticas ........... 33

4.5. Veículo compactador do solo ............ 36

4.5.1. Características do veículo ........ 36

4.5 .2 . Distribuição da carga .......... 36

4.6. Implemento descompactador ............. 38

4.7. Preparo da área para o experimento ....... 38

4.8. Processos operacionais de campo ......... 38

4.8.1. Canaletas para amostragem do solo ... 38

4.8.1.1. Trincheiras ........... 41

4.8.2. Compactação do solo ............ 41

4.8.2.1. Obtenção da umidade ño solo. 41

4.8.2.2. Amostragens para as densidades de compactação ........ 43

4.8 .2 .3 . Obtenção das amostras ..... 43

4.8.3. Descompactação do solo .......... 44

4.8.3.1. Amostragens para as densidades após descompactação .... 44

4.8.3.2. Obtenção das amostras ..... 44

4.9. Análisés das densidades das amostras ...... 44

4.10. Colheita do experimento ............. 47

4.10.1. Análises tecnológicas .......... 47

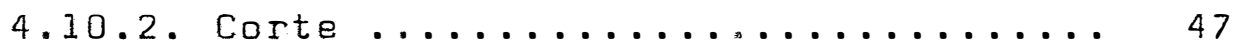

4.10 .3 . Contagem da população ........ 47

4.10 .4$. Pesagem das produções ...........4 48

4.11. Estudo do sistema radicular............ 48

4.11 .1 . Amostragem ................ 48

4.11 .2 . Dimensão e número de amostras .... 49

4.11.3. Preparo e pesagem das amostras .... 49

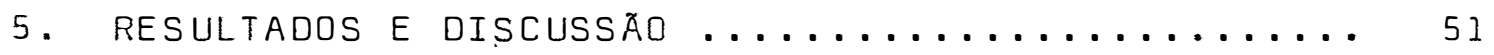

5.1. Produção da cana-planta ................ 51

5.2. Efeito da compactação do solo ........... 51 
Pägina

5.2 .1 . Umidade no solo ............... 51

5.2 .2 . Densidade após compactação ........ 52

5.3. Efeitos da subsolagem na densidade do solo. 59

5.4. Efeitos na produção de cana .............. 81

5.4.1. População de colmós .............. 81

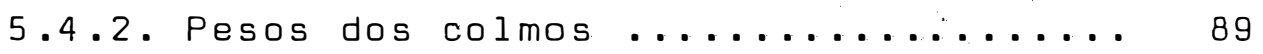

5.4 .3 . Rendimentos agrícolas ............ 93

5.5. Anälise tecnológica ................. 97

5.6. Sistema Radicular .................... 101

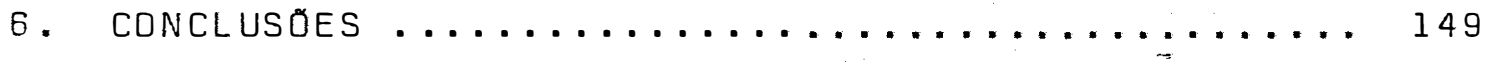

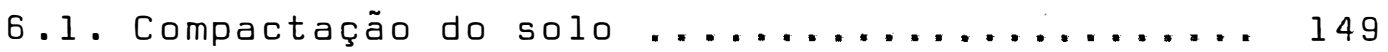

6.2. Subsolagem ....................... 150

6.3. Sistema Radicular .................. 150

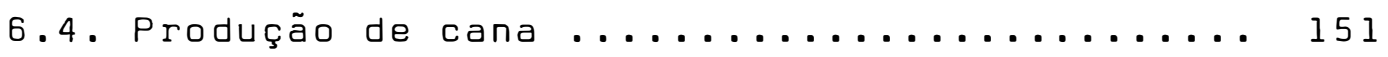

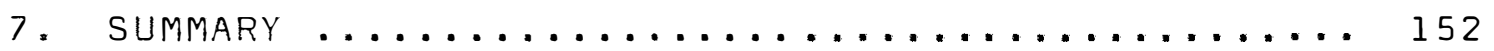

8. LITERATURA CITADA ..................... 153 


\section{RESUMO}

Em Latossol Vermelho Escuro-fase argilosa, com a Var. CB41-76 de $2^{\circ}$ corte, foram realizadas operações de compactação do solo usando veículo de transporte de cana,pas sando 1, 2 e 3 veizes na mesma faixa. Em seguida foram feitas subsolagens em ambos os. lados das linhas de cana, distan tes 30,50 e $70 \mathrm{~cm}$ em relação ao centro do sulco e a $25 \mathrm{~cm}$ de profundidade, através de implemento com asas na extremida de inferior da haste. Foram constatados efeitos comulativos de compactação nas áreas com 2 e 3 passadas do veículo. Os resultados mostraram, como mais convenientes à soqueira da cana-de-açúcar, a subsolagem feita a 30 e $50 \mathrm{~cm}$, nos tratamentos com l e 2 passadas. Nas äreas em que o veículo passou 3 vezes não houve nenhum efeito para as 3 distáncias das subsolagens.

Ambos os tratamentos de compactação e de subso lagens não mostraram efeitos significativos no peso total das ralzes. Apenas pequenas diferenças foram verificadas na dis tribuição do sistema radicular nos perfís do solo. 


\section{INTRODUÇAOO}

- Brasil ocupa a destacada poisção de maior produtor mundial de cana-de-açúcar.

Segundo informa o Relatório Anual do PLANALSUCAR (1977), a área total com cana naquele ano aproximou-se de 2,2 milhões de hectares.

Desse total, o Estado de São Paulo participou com quase um milhão de hectares plantados com a cana-de-açü car, equivalente portanto, a quase metade da área canavieira do país.

Estudo realizado por CARUALHO \& GRAÇA (1976), com base em levantamentos das áreas próprias de 72 usinas do Estado de São Paulo, compreendendo os 4 ciclos agrícolas con secutivos de $1972 / 73$ a $1975 / 76$ revelaram rendimentos médios de 94,2 t/ha de cana para o $I^{\circ}$ corte e de $67,5,54,5$ e 40,4 t/ha para as soqueiras de $2^{8}, 3^{8}$ e $4^{8}$ corte, respectivamente. Houve, portanto, uma redução média de $24,5 \%$ no rendimento agrícola de cada corte em relação à produtividade do corte 
anterior. O trabalho permite observar que a nível de sub-re giões, onde são constatadas variações nos rendimentos agríco las em relação à média geral, as quedas verificadas entre os vários cortes guardam equivalentes proporções em termos porcentuais. Os autores ressaltam a conveniéncia de melhores atenções ao comportamento das canas-socas, porquanto representam quase $60 \%$ da produção agrícola do Estado.

Tal consideração deixa evidente a maior respon sabilidade das soqueiras pelos baixos rendimentos agrícolas de nossa cultura, decorrentes de fatores influentes nesse es tágio da cultura e que não têm sido contornados através dos. tratos culturais mais adequados.

Observadas as modalidades operacionais de cor te, carregamento e transporte da cana, pode-se constatar a introdução de máquinas e veículos com capaciädades de trabalho cada vez maiores, nos últimos anos.

Sua passagem nas áreas de cultivo tem sido res ponsável pela compactação do solo e suas consequéncias sobre o mau desempenho do sistema radicular da cana-de-açúcar.

O manejo do solo como trato cultural das soqueiras tem consistido basicamente em uma operação de subsolagem realizada na entrelinha, utilizando implemento com has te lisa.

Como resultado, a cultura não encontra as mais adequadas condições físicas no solo para o melhor desenvolvi mento vegetativo.

Mais recentemente, algumas empresas têm empregado o subsolador em ambos os lados da linha de cana, mas sem os necessários parámetros experimentais.

Este trabalho foi elaborado objetivando informações em condições de campo, sobre o comportamento da cana- de-açúcar, cujo sistema radicular tenha se desenvolvido em solo submetido a diferentes intensidades de compactação por veículo de transporte, seguida da subsolagem a 3 distáncias da linha de cana com subsolador alado. 


\section{REVISAOO DE LITERATURA}

3.1. Compactação do Solo

GILL (1959) define a compactação do solo como o resultado do movimento de aproximação das partículas por força externas.

Para HARRIS (1971) uma alteração na condição de compactação de solo é o resultado de uma mudança no volume desse solo, causada por forças mecánicas. 0 autor considera que o solo deve ser descrito em termos de um esqueleto de partículas sólidas de dimerisóes variáveis, circundadas por espaços, os quais devem conter substáncias líquidas ou gasosas. Quando submetido o solo a uma carga aplicada, capaz de causar uma mudança no seu volume, quatro tipos de ocorrên cia se verificarão: a) uma compressão nas partículas sólidas; b) uma compressão dos líquidos e gases contidos nos poros; c) uma mudança nos teores de líquidos e gases nos poros e d) um rearranjamento das partículas sólidas. Em termos dimen- sionais, essa mudança de volume é função de vários fatores. 
destacando-se o tipo do solo, tamanho e distribuição das par ticulas, tipos das argilas, teores de umidade, etc.

Os pesquisadores concordam em que as medidas dos esforços causados por uma roda em movimento sobre uma su perficie como o solo, constituem tarefa bastante dificl, devido às interferéncias de vários fatores influindo nos calcu los teóricos.

Segundo COHRON (1971), algumas das primeiras medições sobre a distribuiçäo das forças provocadas pela ro da de um velculo na massa do solo foram obtidas por vander Berg et ali1, em 1956. Eles utilizaram um trator com roda de pneumático, tracionando um arado, em solo arenoso, cujos resultados são mostrados na figura abaixo.

\section{FORCES CAUSING SOIL COMPACTION}

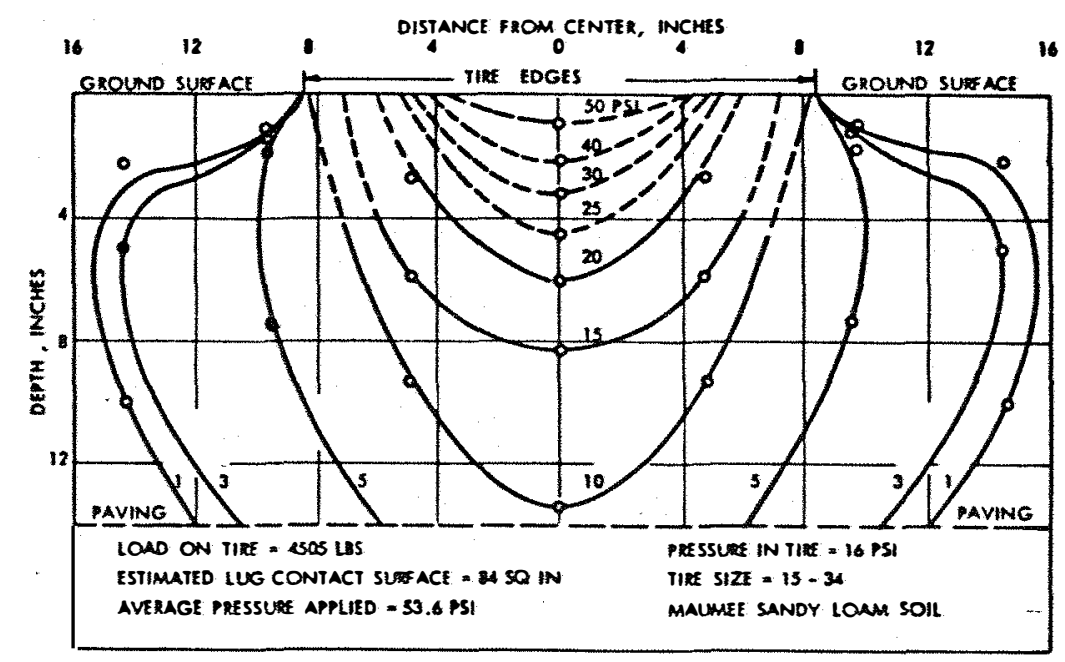

Equal vertical stress lines under the rear tractor tire in a dense soil placed on pavement. (Vanden Berg, et al., 1957)

Mas Zelenio em 1950, citado por GILL (1968). estudando a distribuição das forças de compressão sobre uma superficie formada por particulas não cimentadas, apresentou a Figura esquemática apresentada a seguir, segundo a qual. os valores máximos de compressão formam nos perfís do solo um triángulo, cujos laterais obedecem um ángulo de $45^{\circ}$; valo res em escala decrescente se expadem para fora da projeção da base que provoca a compressão. 
(A)

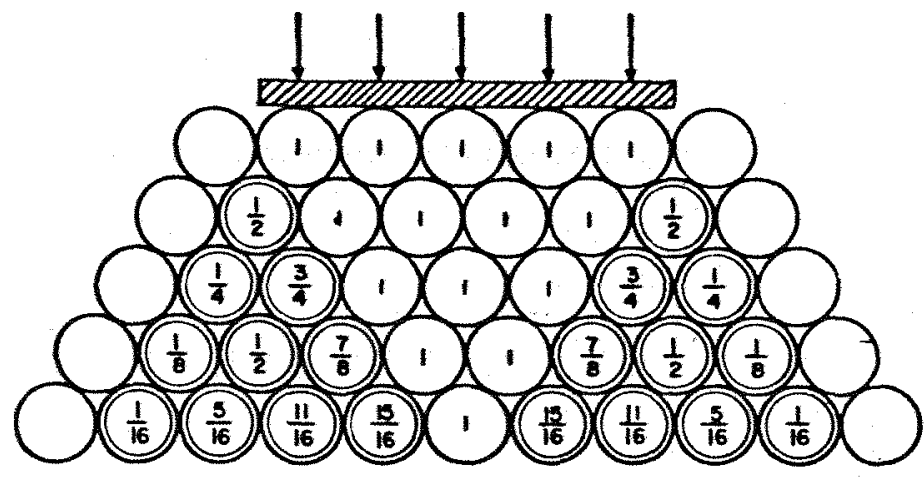

(B)

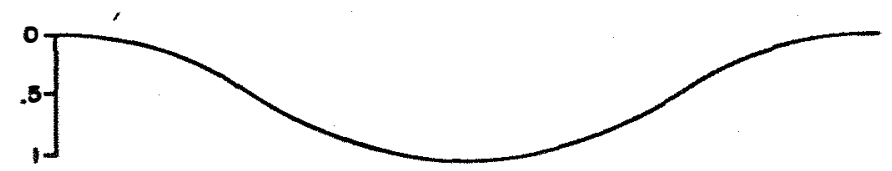

$A$, Idealized nature of arching; $B$, vertical stress distribution for an idealized granular materiai. (Zelenin ( 515$).$ )

O autor considera que, para o solo como um meio bastante desuniforme, os efeitos da compactação por forças externas são diferentes para cada condição, tanto do preparo do solo como da superfície compactante.

TAYLOR \& BURNETT (1963) submeteram 4 parcelas de solo limo-arenoso à irrigação até a capacidade de campo. Em seguida provocou a compactação de 2 parcelas por um trator de pneus passando 2 vezes na mesma faixa. Após 4 dias foi repetido o processo de compactação. Seis meses após fo ram retiradas amostras do solo e avaliadas as densidades, sen do constatado que, de 1,61 as parcelas passaram para 1,79 $\mathrm{g} / \mathrm{cm}^{3}$.

GROHMANN \& QUEIROZ NETO (1966), em condiçōes de laboratório, provocaram compactaçōes a diversos níveis. obtendo os valores apresentados no quadro a seguir. 


\begin{tabular}{|c|c|c|c|c|c|}
\hline \multirow[t]{2}{*}{ Solo } & \multirow{2}{*}{$\begin{array}{l}\text { Densidade } \\
\text { Aparente }\end{array}$} & \multirow{2}{*}{$\begin{array}{c}\text { Porosidade } \\
\text { Total }\end{array}$} & \multirow{2}{*}{\multicolumn{2}{|c|}{$\begin{array}{c}\text { Agua } \% \\
\text { em volume }\end{array}$}} & \multirow{2}{*}{$\begin{array}{l}\text { Poros } \\
\text { livres }\end{array}$} \\
\hline & & & & & \\
\hline \multirow[b]{3}{*}{ Latossol } & 1,32 & 55,7 & & 35,2 & 20,5 \\
\hline & 1,38 & 53,7 & & 36,9 & 16,8 \\
\hline & 1,50 & 49,7 & & 40,7 & 9,0 \\
\hline \multirow[t]{3}{*}{ Roxo } & 1,23 & 58,7 & & 39,4 & 19,3 \\
\hline & 1,36 & 54,4 & & 43,4 & 11,0 \\
\hline & 1,49 & 50,0 & & 46,7 & 3,3 \\
\hline \multirow[b]{3}{*}{ Pod. Verm. } & 1,25 & 52,8 & & 26,1 & 26,7 \\
\hline & 1,32 & 50,2 & & 25,4 & 24,8 \\
\hline & 1,42 & 46,5 & & 28,1 & 18,4 \\
\hline \multirow[t]{3}{*}{ Amarelo-orto } & 1,04 & 60,8 & & 30,0 & 30,8 \\
\hline & 1,28 & 51,7 & & 37,1 & 14,6 \\
\hline & 1,40 & 47,2 & & 41,1 & 6,1 \\
\hline
\end{tabular}

MOBERLy (1969), estudou também a redução dos poros livres de um solo submetido à compactação, obtendo a seguinte proporção entre as densidades aparentes e as porcen tagens de macroporos até 20 cm de profundidade:

\begin{tabular}{ccc} 
Tratamentos & $\begin{array}{c}\text { Densidade } \\
\left(\mathrm{g} / \mathrm{cm}^{3}\right)\end{array}$ & $\begin{array}{c}\text { Macro-poros } \\
(\%)\end{array}$ \\
\hline Não subsolado & 1,52 & 10,9 \\
Subsolado a $40 \mathrm{~cm}$ & 1,45 & 14,2 \\
Subsolado a $60 \mathrm{~cm}$ & 1,41 & 18,2 \\
\hline
\end{tabular}

Em 1959, também citados por GILL (1968) Soheme et alii estudaram a distribuição da porosidade de um solo submetido a -uma carga de $12,5 \mathrm{~kg} / \mathrm{cm}^{2}$, obtendo como resultado, 
uma figura cujo ponto de máxima compactação e consequente malor redução do Indice de porosidade, situou-se no encontro das 2 linhas descendo segundo um ángulo de $45^{\circ}$ a partir dos bordos da superficie compactante. Nesse ponto a porosidade fo1 reduzida de $49,9 \%$ a $33 \%$.

A mesma figura, desta vez contendo valores em termos de densidade relativa do solo, é apresentada por Chan cellor et al1i, em 1962, conforme c1tação de LARSON \& ALLMARAS (1971). As l1nhas unindo os pontos de igual valor forma ram a Figura abaixo.

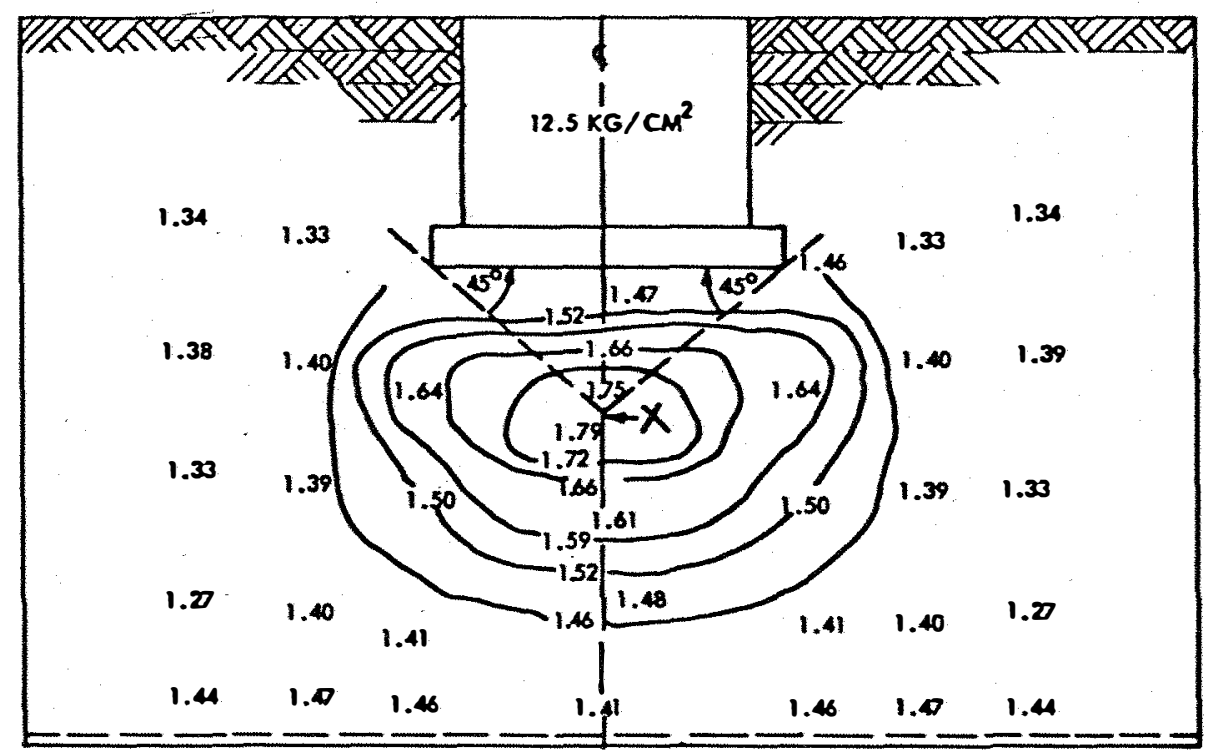
2.., 1962.)

-Lines of equal bulk density $\left(\mathrm{g} \mathrm{cm}^{-3}\right)$ caused by a rigid phenger. (Chancellor et

3.2 .

Des compactação do Solo

Como descompactação do solo entende-se, logica mente a reduçào da densidade relativa, através do aumento do volume. Fatores contrários ao da compactação deverão ocorrer, istoé, aumento da proporção dos macroporos, descompres sào da fase líquida e um rearranjamento das partículas e/ou agregados do solo.

GILL (1968), ilustra uma ferramenta com asas na extremidade inferior da haste e comenta sua atividade ope racional que a tornam um implemento adequado à descompactação 
do solo como trato cultural. Os recursos oferecidos pelo conjunto máquina-implemento, permitem a melhor posição quanto à inclinação das asas para a adequada execução do trabalho, de vez que esta é função de vários fatores, destacando-se a velocidade da máquina e o àngulo de ação das asas.

\subsection{Relação Solo - Sistema Radicular}

Segundo TROUSE (1971), as raízes de algumas plantas podem crescer até $12 \mathrm{~cm}$ por dia, em condições ideais; alongamentos de $5 \mathrm{~cm}$ por dia não são excepcionais para muitas culturas.

HUMBERT (1974), afirma que já foram registrados crescimentos das rázzes de cana-de-açūcar até 8 cm por dia. São também desse autor duas considerações de fundamental im portáncia: a) o sistema radicular se adapta às características do meio ambiente; b) o volume das raízes, seu peso e seu comprimento, não caracterizam de forma completa a capacidade do sistema radicular para absorver a umidade e os nutrientes. Cita ainda, informações de pesquisadores de Maurício, Formo sa e Barbados, segundo os quais, "não há necessariamente uma correlação entre a relação cana - raízes e o rendimento e ca pacidade das diferentes variedades" e que, "em solos férteis, uma quantidade relativamente menor de raízes é requerida pa ra a produção da parte aérea".

Sobre a distribuição do sistema radicular da cana-de-açúcar, Lee et alii, em 1926, citados por Van DILLEWIJN (1952), concluiram que mais de $85 \%$ em peso estão acima de $50 \mathrm{~cm}$ quando no estágio de cana-planta irrigada.

INFORZATO \& ALUAREZ (1957), encontraram 75,6\% das raizes da Var. Co290 nos 50 cm superficiais para cana-planta em terra roxa de Araraquara-SP.

Em Latossol Vermelho Escuro de Araras-SP, SOUSA (1976), estudou o comportamento do sistema radicular da cana-planta, -Var. CB41-76 mantido através de irrigação a 3 
níveis mínimos de água no solo, sendo $25 \%, 50 \%$ e $75 \%$ da capa cidade de campo, além do tratamento testemunha, que permaneceu sob condições naturais, sem irrigação. Os resultados na data do corte, aos 18 meses, revelaram concentrações de 63,8\%, $62,0 \%$, 64,1\% e 60,0\%, respectivamente para os 4 tratamentos, nos $40 \mathrm{~cm}$ da camada superior do solo. Esses valores somaram $83,2 \%, 82,0 \%, 83,2 \%$ e $75,2 \%$ até $60 \mathrm{~cm}$ de profundidade nos mesmos tratamentos.

Pesquisas realizadas por Evans em 1936, em Mau rício, conforme citação de HUMBERT (1974), mostraram que aproximadamente $70 \%$ dos pêlos radiculares se localizam nos primeiros 33 c̄m da superfície e que quase $90 \%$ estão distribuidos a uma "distáncia maior que $33 \mathrm{~cm}$ " do pé da planta.

Com referéncia à cana-soca, citando vários pes quisadores e o próprio autor, HUMBERT (1974), afirmou que o sistema radicular é "menos bem desenvolvido" que o da cana-planta.

Segundo Humbert, Yamasaki e Evans, citados por HUMBERT (1974), as raizes da cana cortada permanecem ativas "por um considerável período", enquanto são gradualmente substituidas pelas raízes da nova brotação.

3.4. Efejtos da compactação do solo no sistema radi cular de algumas culturas.

HUMBERT (1974), afirma que em solos compactados com aeração limitada, o sistema radicular mostra-se pra ticamente desprovido de ramificações secundárias. 0 autor menciona que nos latossolos pouco úmicos do Hawai, representando $40 \%$ dos campos com cana-de-açúcar, observaram-se raízes deformadas ou distribuição restringida quando cultivadas sob condições de densidade do solo abaixo de 1,02; sob densi dade 1,25 são observados danos nas radicelas; reduzida a quantidade das raízes e distorsão das radicelas com 1,36; se riamente comprómetida a penetração no solo com densidadel,46. 
VEIHMEYER \& HENDRICKSON (1948), submeteram a esforços de compactação, em condições de laboratório, 6 tipos de solo contendo diferentes composições granulométricas, a fim de testarem a capacidade de penetração das raízes do girassol. Os resultados mostraram que os solos argilosos são mais compactáveis que os arenosos. Em solo argiloso, conten do $25 \%$ de areia, $26 \%$ de limo e $49 \%$ de argila, compactado até densidade 1,46 não foram encontradas raízes,. enquanto que em solo arenoso, com $72 \%$ de areia total, $17 \%$ de limo e $11 \%$ de argila, sob densidade 1,56, as raízes conseguiram penetrar.

MARTINEZ \& LUGO-LOPEZ (1953) em Porto Rico, es tudaram os efeitos da subsolagem combinada com a aplicação de fertilizantes em cana-planta. O subsolador foi regulado para penetrar até $76 \mathrm{~cm}$ no solo. A área foi proveniente de pastagem como cultura anterior a plantio da cana. Como re sultado, os tratamentos subsolados ou não, que receberam os fertilizantes em superfície, inclusive a testemunha, produzi ram a média de $10.376 \mathrm{~kg} / \mathrm{ha}$ de açúcar, enquanto que, os tratamentos que receberam metade dos adubos em superfície e metade em profundidade, juntamente com a subsolagem, a produção média foi de $11.995 \mathrm{~kg} / \mathrm{ha}$ de açūcar. Quanto à influência so bre a infiltração da água no solo, os índices foram de 5,6 e 0,5 polegadas por hora, respectivamente nos tratamentos subsolados e as testemunhas sem subsolagem.

WIERSUM (1957), elaborou um experimento visando observar a capacidade das raízes de penentrarem em substra tos contendo poros de diferentes diámetros. Para tanto foi levada em conta também a rigidés dos poros, admitindo-se que, sob as condições de campo, as rázes podem deslocar as partículas. A rigidês dos poros foi conseguida através de areia com partículas de diámetros conhecidos e uniformes, deposita dos em tubos longos e de diámetros adequados para não movimentação interna do substrato. D autor constatou que o diámetro dos poros é fator limitante para a penetração das rarzes de diámetro superior. Como consequéncia, torna-se difícil julgar entre a resisténcia mecánica encontrada pelas ra zes ao seu crescimento e outras condições, como excesso de 
umidade, insuficiente aeração do solo, etc.

GILL (1959), considera que a compactação do sa lo ocorre quando este se encontra em condições suceptíveis a tal processo, destacando-se: a) quando o solo está solto e toda pequena força resultará na redução do volume; b) quando - solo está úmido e a força compressiva é baixa, pequenos es forços levarão o solo de novo à compreśsão e rachaduras; c) como aspecto importante deve ser consideradó o fato de que a profundidade de compactação aumenta na medida em que sejam maiores as forças compactantes aplicadas; d) a repetição das passagens das cargas resulta em maior compactação. Ainda na opinião do autor a compactação afeta o crescimento das plantas nos aspectos seguintes: l) reduzindo as porcentagens dos macroporos, com redução da capacidade de infiltração da água nos perfís do solo; 2) a redução no volume dos macroporos di minui as trocas gasosas na massa do solo, com prejuízo no sü primento de oxigènio às raízes; 3) certos elementos como o Fe e o Mn podem passar às formas reduzidas em meio pobre de oxigènio tornando-se tóxicas às raízes, tornando difícil sua correção.

ZIMMERMAN \& KARDOS $(1961)$, estudaram o crescimento das raízes da soja e da grama do sudão em solos argilo sos e arenosos, sob condições naturais e artificiais de com pactação. Os resultados mostraram que as raízes da gramínea penetraram mais prontamente no solo compactado. Ambas as culturas apresentaram uma correlação inversa entre os valores das densidades dos solos e os pesos das rázes que neles penetraram. Nos solos argilosos. a penetração ficou virtualmente excluída na densidade de 1,8 , enquanto que nos solos arenosos aquela condição foi encontrada nas densidades de 1,9 e 2,0 .

\section{RICHARDS et alii (1960) usaram 7 tipos de solo} contendo diferentes composições granulométricas, submetendo-os ao esforço de compactação sob 3 níveis de umidade. Os autores concluiram que, a estrutura do solo está associada com a aração e os fatores de disponibilidade de água para a 
ambientação das raízes. A resistência do solo à compactação e os índices de condutividade dos solos compactados parecem ser os fatores que merecem cuidadosas avaliações.

GILL (1961), considera erróneas as opiniões de alguns pesquisadores quando enfatizam a capacidade das raízes de penetrarem em meios compactados. Referindo-se às conclusões de Pfeffer, em 1956, segundo as quais, as raízes podem desenvolver esforços correspondentes a 26 e 6 atmosferas, res pectivamente nas direções exial e lateral, o autor comenta que tais circunstáncias provocam enrugamentos e torções nas raizes, com severas anormalidades anatómicas. Tais efeitos têm reflexos nos fenómenos fisiológicos, já prejudicados pẹ las deficiências nos níveis de oxigênio.

VOMOCIL \& FLOCKER (1961), consideram o solo c므 mo um "pacote" de tubos capilares, cujos tamanhos ficam em função dos tamanhos dos poros. Quando o solo é comprimido, a distribuição dos tamanhos do poro sofre grạdes variações bem como, a porosidade total. Portanto, essa keriável serve como um sensivel indicador da compactação. Comok movimento da água no solo depende do índice de capilaridade, obviamente a permeabilidade do solo aos fluídos é de fundamental im portáncia para o crescimento das plantas. Segundo os autores, a interação entre o solo como um complexo químico, físi co e microbiológico e as exigências vitais das plantas, não é condição simples. Em sua opinião, a demanda pelas plantas quanto ao solo como um meio físico, varia com a espécie, ida de, etc. Como exemplo os autores apresentam algumas culturas e respectivos valores mínimos de porosidade, abaixo dos quais ocorrem apreciáveis reduções nas produções. Entre elas está a cana-de-açúcar com valores entre 9 e $10 \%$.

GROHMANN \& ARRUDA (1961), realizaram durante 12 anos, um estudo com diferentes modalidades operacionais de preparo do solo e suas influências na estrutura dos agregados da terra-roxa-ligitima. Os resultados revelaram que, no tratamento com 2 arações, os agregados apresentaram um diámetro médio de 0,54 milímetros, enquanto que, nos tratamentos com 
somente uma aração com arado de aivecas e com o preparo do so lo unicamente com a enxada manual, os diámetros mediram res pectivamente 0,70 e $0,95 \mathrm{milimetros.} \mathrm{Os} \mathrm{autores} \mathrm{concluem} \mathrm{que}$ a terra-roxa-ligitima conta com características expecionais de estrutura, podendo ser prejudicadas pelo uso intensivo do arado no preparo para o plantio.

TROUSE \& HUMBERT (1961), informam que os rendi mentos de 132,6 t de cana e 11,25 t de açúcar por hectare man tidos como médias durante vários anos consecutivos, caíram respectivamente, para $90 \mathrm{t}$ e 8,85 t por hectare, após 2 anos consecutivos de colheita mecanizada no Hawai. Uma área com 3 cortes mecanizados, tiveram seus rendimentos baixados para 56 t de cana e 5,85 t de açúcar por hectare. Nas regiões chuvosas os danos causados pela compactação são mais severos que naquelas onde se torna necessária a irrigação. Aqui a irrigação é interrompida a fim de provocar o amadurecimento da cana e comisso a colheita é realizada com solo seco. Os a tores estabeleceram uma série de experimentos, visando estudar o comportamento das raízes da cana em solos com diferentes densidades. Os resultados revelaram que o sistema radicular mostrou restrições no crescimento a partir de densidades ao redor de 1,20 para o latossolo pouco húmico; até 1,25 a distribuição de raízes foi razoavelmente satisfatória, mas apresentando deformações; a densidade de 1,46 reduziu seriamente a penetração das raízes. Para os vários tipos de solo, - aumento da densidade de 1,04 para 1,55, resultou na redução de $50 \%$ do volume inicial de poros na massa do solo.

MEREDITH \& PATRICK Jr. $\mid 1961)$, estudaram também os efeitos de diferentes níveis de compactação artificial sobre a penetração das raízes e as propriedades físicas de 3. solos com texturas médias, em área de baixada de Louiziana, de forma a permanecer a umidade constante ao nível de $50 \%$ du rante 6 meses e mantido o cuidado para que a proporção de ar não caísse abaixo de $10 \%$ em todos os tratamentos. Os autores verificaram que os maiores aumentos nos valores de densi dade, ocorreram nos primeiros esforços de compactação; os ma croporos mostraram-se extremamente sensiveis à compactação ; na medida em que eram elevados os indices das densidades - 
$(1,65$ a 1,70) todos os poros não capilares eram destruídos. A permeabilidade à água tendeu a zero sob o esforço compactante de 15 lb/pol ${ }^{3}$ do solo. Quanto à capacidade de penetra ção das raízes, houve uma correlação direta com os níveis de poros não capilares para os 3 tipos de solo.

\section{TAYLOR \& BURNETT (1963), relatam 2 experimentos} instalados em 1959 e 1961, visando estudar o comportamento do sistema radicular de várias culturas em solo arenoso, com pactado artificialmente. Foram usados tratores de pneumáticos, sendo feitas 4 passadas com trator de 3.840 kg e 2 passadas com trator pesando $5.500 \mathrm{~kg}$, respectivamente nos 2 tra

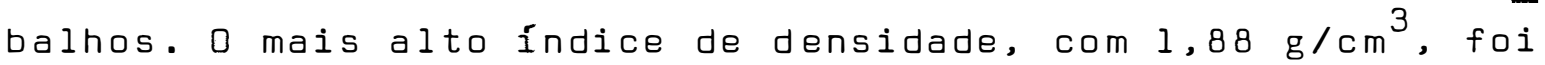
encontrado na camada do solo entre 10 e 15 cm de profundidade em ambos os experimentos. Embora tenha havido boa unifor midade na germinação, as plantas do algodoeiro, nas parčelas não descompactadas, começaram a morrer após algumas semanas. No tratamento sem operações de preparo do solo, após a compactação houve acentuada redução no peso de raízes, em relação aos tratamentos preparados para o plantio.

PASSIOURA \& LEEPER (1963), comentam os problemas da doença ocorrida na aveia, conhecida como "mancha parda", quando cultivada em solos arenosos e turfosos, de $\mathrm{pH}$ en tre 6,5 e 8,0. As razões têm sido apontadas como sendo a oxidação biológica do $M n$ a $\mathrm{MnO}_{2}$, uma forma insolúvel no solo, portanto, não disponível às plantas. Mas outros solos neutros, a despeito dos seus baixos teores não mostram as mesmas deficiências de Mn, especialmente os solos orgánicos. Como consequéncia, foi sugerida a compactação como a causa. Nesse sentido um experimento foi instalado em vaso, mantidos tratamentos dentro e fora da casa de vegetação. Dois solos arenosos foram estudados, ambos com $\mathrm{pH} 7,4$ variando as densi dades entre 0,85 e 1,50. As produções nos vaso mantidos em estufa, foram para a variedade de Algeria (sensivel), de 0,49

$g$ de grãos por vaso no solo descompactado, e de 2,3 g nos so los compactados. A variedade Palestina (tolerante à deficiência do Mn\} produziu $9,1 \mathrm{~g}$ e $1,3 \mathrm{~g}$ de grãos, respectivamente no solo compactado e não compactado. Também os pesos de 
matéria seca foram bem elevados quando as plantas foram cultivadas em solos com maiores densidades. Os autores supõem que as próprias raízes sejam capazes de agir através da "redução de contato", analoga à "troca de contato", como ocorre com os catíns em geral. Sendo maior a área de contato das raízes com as partículas do solo em condição de maior densidade, esta poderá ser a melhor explicação.

MONTEITH \& BANATH (1965), procuraram determinar entre a densidade do solo, a porosidade até $50 \mathrm{~cm}$ de ten são de água e a resisténcia medida pelo penetrómetro, a melhor avaliação da condição física do solo sob baixa tensão de umidade, para o crescimento das rázzes da cana-de-açúcar. Trés tipos de solo com diferentes densidades foram estudados, sendo um limo-arenoso com 1,16 a 1,48; um limoso com 1,15 a 1,73 e um limo-argiloso com 1,16 a 1,76, como valores mínimos e máximos, respectivamente, além de 2 densidades in termediárias cada solo. As medidas das densidades foram obtidas por pesagem e, em seguida, através do penetrómetro, obtendo a tabela com os valores correspondentes. Toletes da variedade Triton foram tratados termicamente e plantados. Os resultados em termos de pesos e de distribuição das raízes no solo, mostraram diferenças altamente significativas em fä vor das menores densidades nos 3 tipos de solo. As restrições ao crescimento das raízes foram visíveis nas densidades de 1,38 no solo limo-arenoso; l,52 no limo-argiloso e de 1,50 no solo limoso. Por outro lado, os autores concluiram pela posibilidade de ser usado o penetrómetro na obtenção da densidade do solo, desde que, mantido um valor padrão para a tensão de ägua.

GROHMANN \& QUEIROZ NETO (1966), utilizando um aparelho compactador manual, estudaram os efeitos da compac tação nas caractesrísticas físicas verificadas em amostras de latossolo roxo e de podzólico vermelho-amarelo-orto, sob diferentes índices de densidade. Foi avaliada também a capa cidade de penentração das raízes do arroz nas várias condições do solo. O latossolo roxo como densidade inicial de 0,98, recebeu compactações até 1,59, enquanto que no podzólico 
vermelho-amarelo-orto variou até 1,48 , com os mesmos esforços compactantes. Os resultados revelaram que houve impedimento físico ao desenvolvimento das raizes do arroz quando as densidades aparentes atingiram valores superiores a 1,42 no la tossolo roxo e a 1,38 no podzólico vermelho-amarelo-orto.

TROUSE Jr. \{1967\}, desenvolveu um trabalho com vários tipos de solo no Hawai, compreeñdendo 4 grandes grupos e submetendo-os a 6 estágios de campactação, visando estudar - comportamento da cana-de-açúcar em cada condição. Os resul tados mostraram,como termos médios para todos os tratamentos, que: a) a proliferação das raizes se tornou comprometida quan do a densidade ultrapassou 1,20; b) sob densitades acima de 1,40 as raízes mostraram deformações nos tecidos celulares do cortex; c) a partir da densidade 1,20, houve decréscimo no peso e no volume de raízes; d) o alongamento das raízes mos trou-se reduzido quando a densidade atingiu 1,20. Quanto à influência da porosidade do solo sobre o comportamento do sis tema radicular, o autor conclui que numa determinação empírica, a proliferação das raízes estará definitivamente reduzida, embora ainda satisfatória para o suprimento da planta, quando o volume de macroporos decresce a valores entre 15 e $25 \%$; sob condições de 5 a $15 \%$ de macroporos, as raízes terão sua multiplicação deficiente e insuficiente para a produção agrícola; abaixò de $5 \%$, poucas raízes terão condições de se desenvolverem.

OLIVEIRA et alii (1968), realizaram estudos sㅇ bre o processo de adensamento dos solos de tabuleiro do Nordeste do Brasil, concluindo ser uma consequência da migração dos coloides minerais e orgánicos para os perfís inferiores, provocada pelas práticas agrícolas superficiais. A obstrução dos macroporos resulta na redução da permeabilidade do solo. Os autores sugerem a aração de sub-superfície com a finalida de de destruir a camada densa, propiciando maior volume de solo às rafzes.

MOBERLY (1969), estudou os efeitos da subsolagem em soqueiras, instalando experimentos em 11 locais, de 
forma a abranger diferentes condições de solo e estágios da cultura da cana. Foram usados implementos subsoladores de hastes convencionais retas. As operações de subsolagem foram feitas no centro das entrelinhas, atingindo profundidades va riáveis de $30,5 \mathrm{~cm}(12 ")$ a $61,00 \mathrm{~cm}(24 ")$. Os resultados mostraram que, dos 11 locais estudados, 3 aparesentaram meno res rendimentos agrícolas, enquanto 7 , sem influência sobre a testemunha e em apenas um local, a produção foi significativamente positiva. Para os estudos das densidades e porosi dade, as amostras foram retiradas de um ponto intermediário entre a linha de cana e o centro da entrelinha, em apenas um dos campos, pelo método do ciclindro e o martelo. Os autores informam não terem encontrado nenhum eféito favorável com referència à aeração do solo e enraizamento mais profundo, mas sugerem a possibilidade de danos ao sistema radicular p lo implemento.

SHULKA \& RAVALO (1976), realizaram em Porto Rí co estudos sobre a compactação provocada no solo por velculos de transporte. Foram estudados 4 áreas de solo argiloso, com 65\% de argila em média. O peso carregado pelo veículo utilizado no experimento, era de "umas 9 toneladas". Foram medidas as resisténcias do solo à penetração com o "penetrómetro gravador", em 6 profundidades de $7,62 \mathrm{~cm}$ ( 3 ") até 45,72 cm (18"), a cada 3 polegadas. Como não foi observado variação nos teores de água nos diversos tratamentos de um mesmo tipo de solo, os resultados não permitiram avaliar qual dos fatores entre a umidade e a composição granulométrica, mais contribuiu para as diferenças de compactação. Os autores concluiram que: a) em todos os campos houve uma compactação significativa até $30,48 \mathrm{~cm}$ ( 12 "); b) uma compactação signifí cativa não implica necessariamente um grau de compactação que retarde o crescimento das raízes da cana; cl todavia, afe ta o movimento do ar e da água, e pode reduzir o rendimento agrícola.

YANG (1977) mediu a compactação provocada no solo pela colhedora mecanizada e por um veículo de transporte com 6 t de cana, passando 2,4 e 6 vezes na mésma faixa. Fo 
ram utilizados 2 tipos de solo limoso, contendo respectiva mente $22 \%, 42 \%, 36 \%$ e $20 \%, 52 \%, 28 \%$ de areia, limo e argila. o trabalho foi feito em condições de solo úmido e solo seco. As densidades iniciais dos 2 solos eram de 1,42 e 1,53, respectivamente para os solos com menor e maior teores de argi1a. Os resultados evidenciaram maior suceptibilidade do so lo menos argiloso aos efeitos da compactação, passando suas densidades de 1,42 para $1,58,1,74$ e 1,78, na condição úmida e de 1,42 para 1,55, 1,69 e 1,70 na condição eeca, medidas nos $10 \mathrm{~cm}$ superiores do solo. Em ambos os solos e nas 2 con dições de umidade, as densidades se tornaram equivalentes en tre 1,5 e 1,6, na profundidade aproximada ơe 35 cm, inclusive no tratamento testemunha não compactado. Quanto à influạ cia na porosidade, a porcentagem caiu no solo menos argiloso de $46,5 \%$ para $33 \%$ e $34 \%$, nas condições de solo úmido e solo seco; no padrão mais argiloso, as reduções foram de 43\% para $36 \%$ e $37,5 \%$ respectivamente. Os rendimentos agrícolas são mostrados no Quadro abaixo, em t/ha de cana.

\begin{tabular}{llll}
\hline \multirow{2}{*}{ Solo } & Ne de & \multicolumn{2}{c}{ Umidade } \\
\cline { 3 - 4 } & Passos & úmido & \\
\hline & 2 & 39,4 & 62,5 \\
& 4 & 34,6 & 58,9 \\
& 6 & 30,3 & 57,7 \\
$36 \%$ argila & 2 & 57,5 & 56,8 \\
& 4 & 53,0 & 54,3 \\
& 6 & 46,4 & 52,1 \\
\hline
\end{tabular}

CASAGRANDE \& GODOY (1975), trabalhando em latos sol roxo modal, estudaram 3 processos de cultivo mecanizado em cana de $2^{8}$ corte: a) usando uma grade com 24 discos de 24 polegadas; b) aplicando um cultivador de enxada que aprofundou até $10-15 \mathrm{~cm}$ e cl utilizando um subsolador com uma haste 
no centro da entrelinha, trabalhando a 40-45 cm de profundidade e mais 4 discos com a finalidade de desmanchar os torrões deixados pelo subsolador. Cada tratamento recebeu 2 ní veis de adubação, sendo 413 e $826 \mathrm{~kg} / \mathrm{ha}$ da fórmula 10-7-14 $\left(N, P_{2} \mathrm{O}_{5}\right.$ e $\mathrm{K}_{2} \mathrm{O}$ ), além do tratamento testemunha sem adubo. Os adubos foram colocados em superfície nos tratamentos a $e \underline{b} e$ a $10 \mathrm{~cm}$ de profundidade no tratamento $\underline{c}$. Os resultados mostraram diferenças significativas para as dosagens de fertili zantes mas não deferiram para as modalidades operacionais de cultivo. 


\section{MATERIAL E METODOS}

\subsection{Area do Experimento}

\subsubsection{Localização}

o trabalho experimental foi instalado em ärea de plantio da Usina Tamoio, onde o cultivo da cana-de-açúcar acha-se implantado há várias décadas, sob os processos convencionais de operações agrícolas.

A sede da Empresa, tendo por ordenadas geogrā ficas os parámetros compreendidos por $21^{\circ} 47$ LAT $S$ e $48^{\circ} 10$ LONG W, localiza-se no Município de Araraquara, Estado de São Paulo, numa $A L T$ de $750 \mathrm{~m}$.

o município faz parte de uma região canavieira com 110.000 ha de cultivo com a cana-de-açúcar, abrangendo 8 indústrias açucareiras, conforme levantamento de 1977 pelo PLANALSUCAR, não divulgado. 


\subsubsection{Condições Climāticas Regionais}

Durante o período compreendido pelo experimen to, as chuvas verificadas na sede da Usina Tamoio, próxima da área, constam das tabelas 1 e 2 .

\subsubsection{Topografia}

Situada em região alta e levemente ondulada, com declividade de $3 \%$ a área do experimentó confere ótimas condições para total mecanização das práticas agrícolas.

\subsubsection{Solo}

O experimento se localiza em área de Latossol Vermelho Escuro-fase argilosa.

Trabalho realizado por RUGAI \& ORLANDO Fo (1973), baseado em levantamento para a safra de 1972/73, informa que $71,77 \%$ da área com cana-de-açúcar no Estado de são Paulo, se assentava em solos pertencentes ao grande grupo La tossol.

A tabela 3 revela a composição granulométrica a cada $15 \mathrm{~cm}$ de profundidade, até $90 \mathrm{~cm}$ segundo a Escala U.S.D.A.

Para as análises da composição química, foram retiradas amostras representando os $45 \mathrm{~cm}$ superficiais do so 10, separadamente nas faixas com as linhas de cana e no cen tro das entrelinhas, com vistas ao conhecimento sobre os resíduos de adubação da cana-planta, cujos resultados constam da tabela 4 .

\subsection{Variedade da Cana}




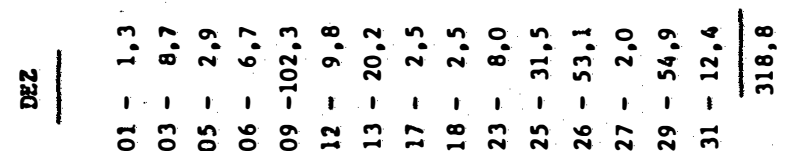

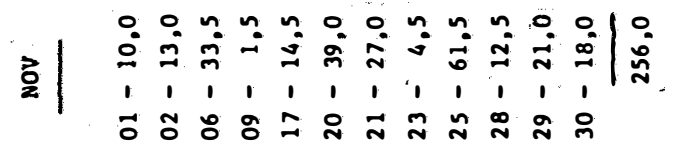

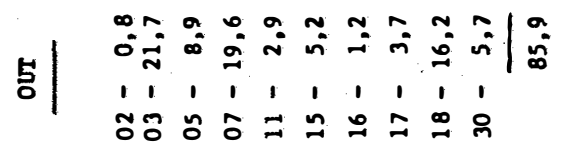

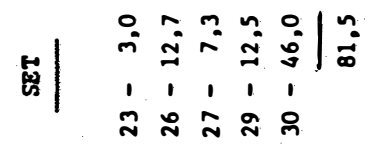

\begin{tabular}{l|l}
8 & $\vdots$ \\
$:$ & 1
\end{tabular}

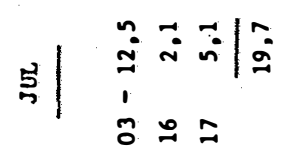

s.s.

㢳|

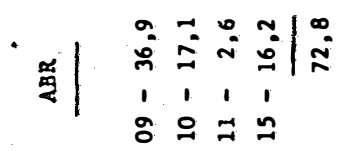

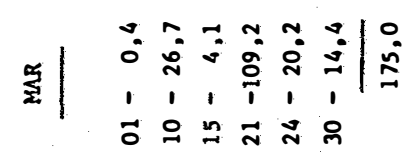

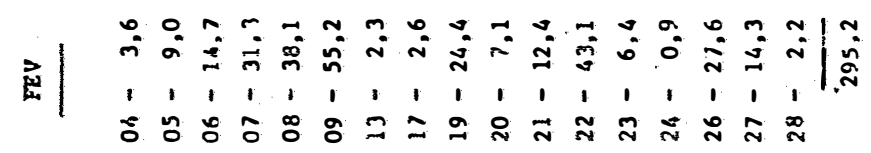

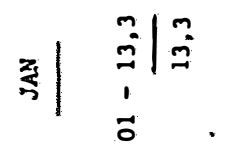




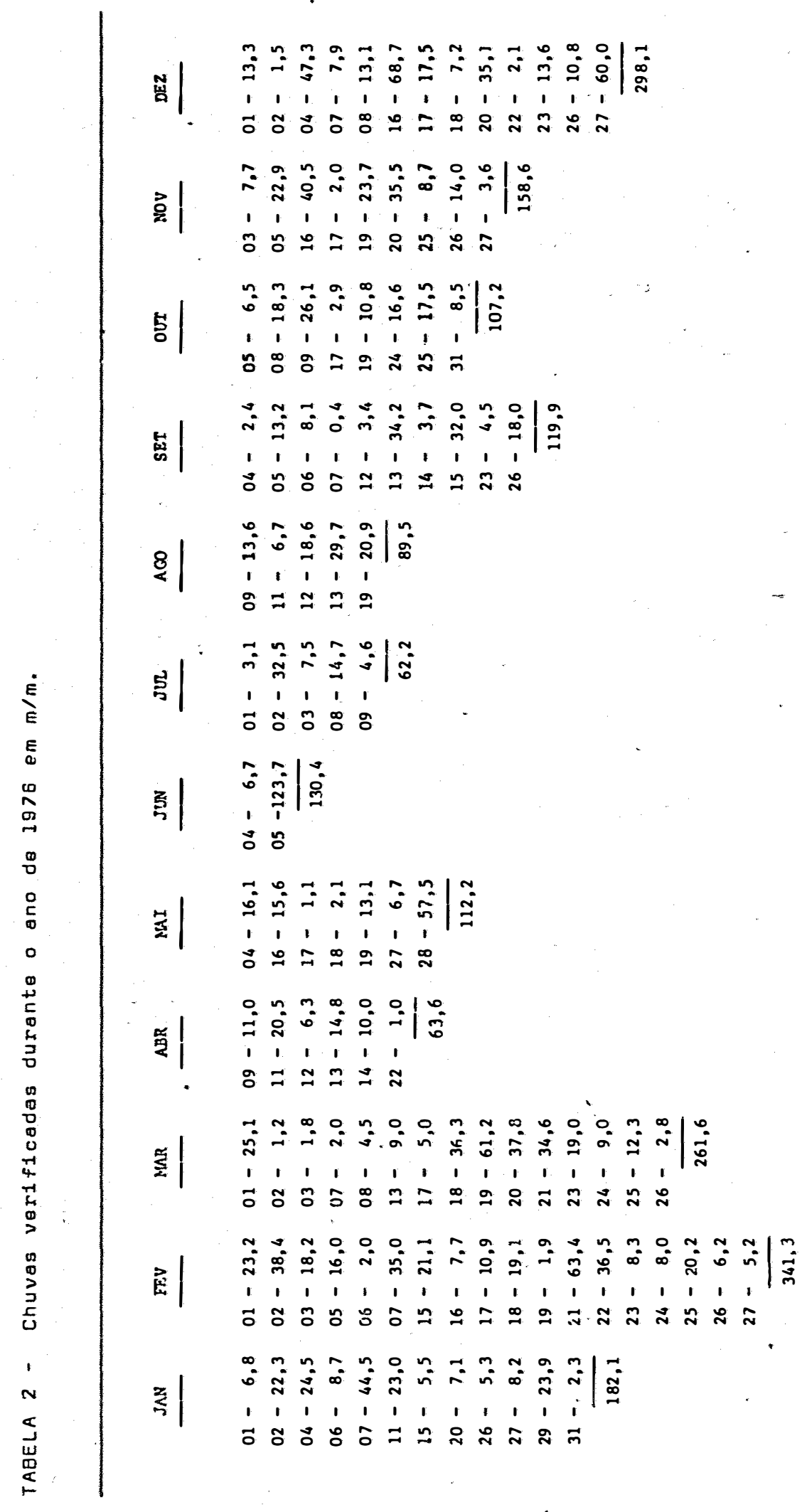




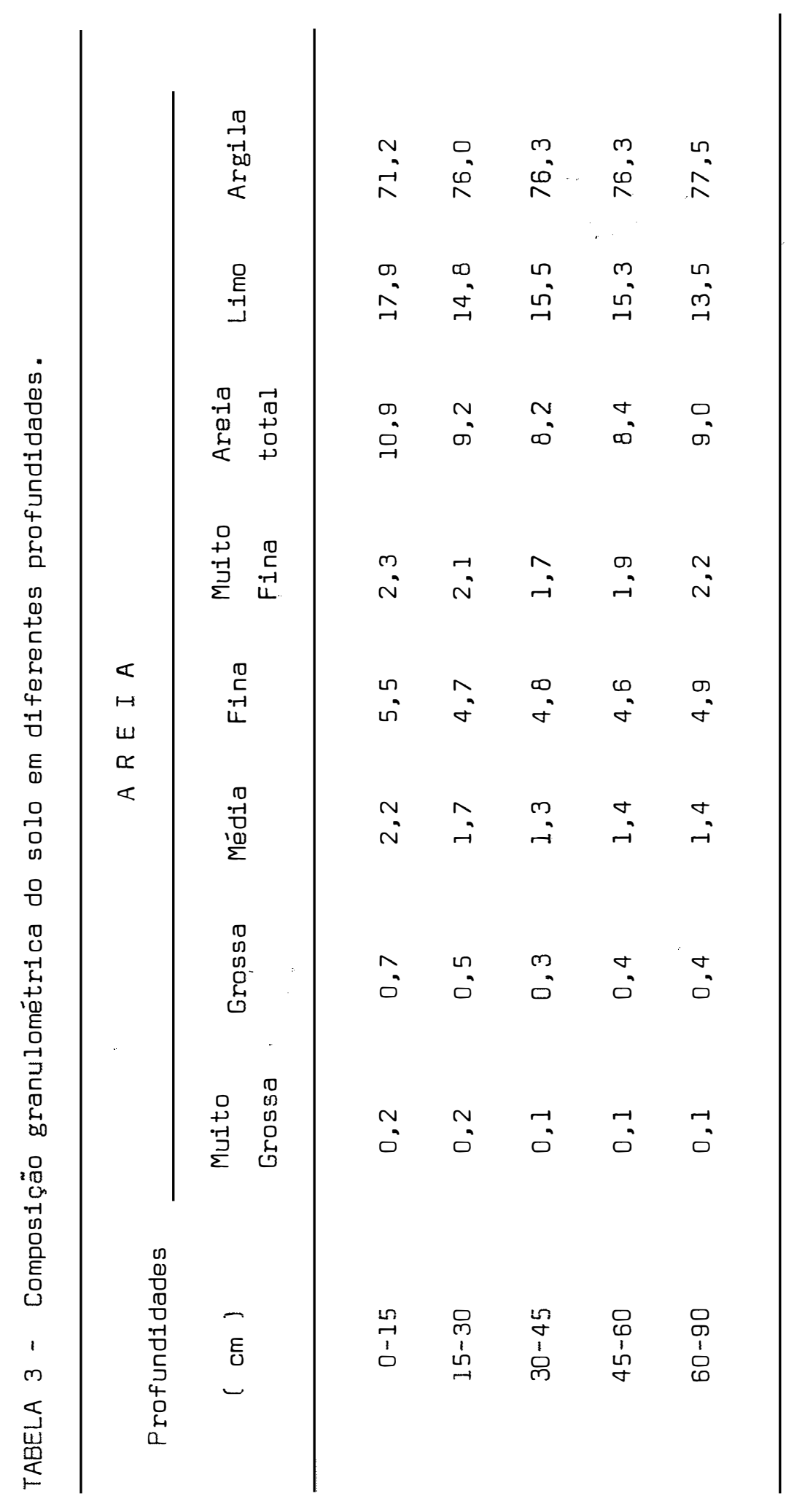




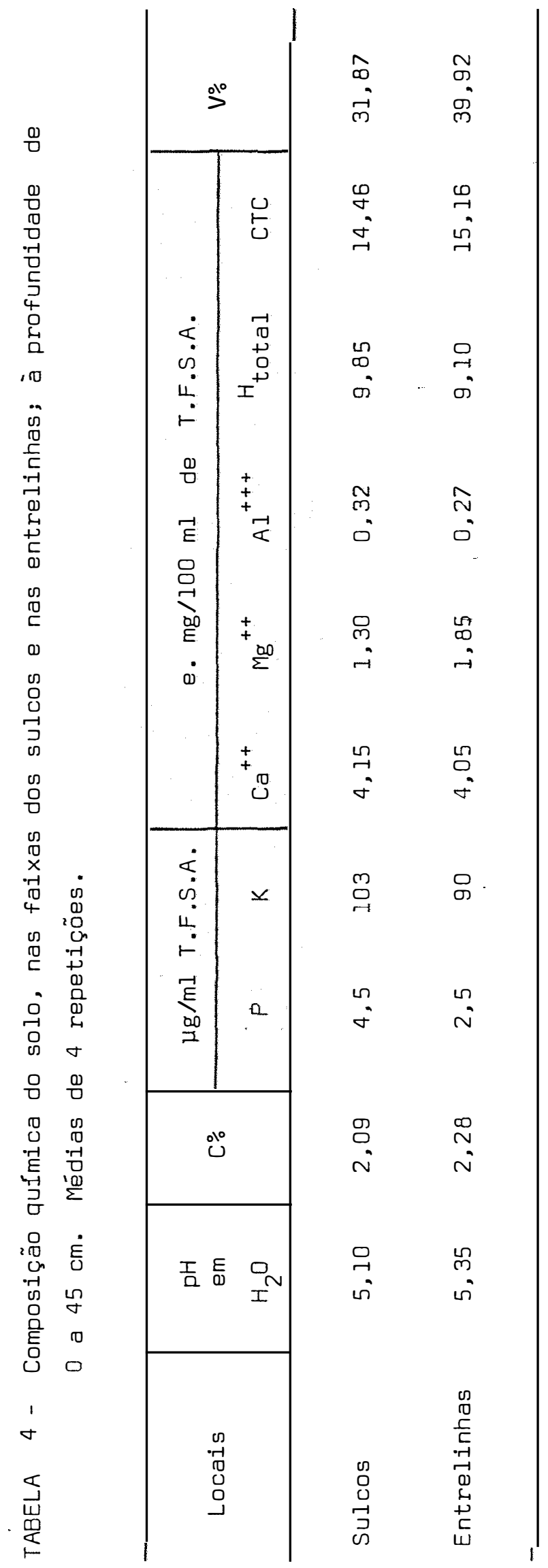


por representar cerca de $32,5 \%$ da ärea cultivada no Estado de São Paulo, segundo PLANALSUCAR (1976).

\subsection{Cana-Planta}

Os aspectos vegetativos referentes à sanidade e ao porte da cultura, mostraram-se satisfatórios para a finalidade do experimento elaborado.

Para efeito de avaliações sobre alguns parámetros previstos para a cana-soca, foram obtidos os valorestam bém da produção do primeiro corte, segundo metodologia discu tida no item 4.3 .3 .

\subsubsection{Preparo do Solo}

Após duas operações cruzadas com a chamada "gra de pesada" com 16 discos de 30 polegadas, pesando $4.100 \mathrm{~kg}$, de tração por trator de esteira, destinada à destruição do re manecente do último corte, a área permaneceu nesse condição por 30 dias.

Seguiram-se as operações propriamente ditas de preparo do solo, constantes de uma aração com arado de discos a 25-30 cm de profundidade e uma gradeação superficial de nivelamento do terreno.

Precedendo o plantio, a área recebeu nova gradeação leve, cuja finalidade principal consistiu na elimina ção das ervas daninhas germinadas.

\subsubsection{Plantio e Tratos Culturais}

0 plantio da quadra em que se localizou o expe rimento, foi feito no final de Fev/74 dentro portanto, do pe ríodo chamado de "Cana de 18 meses". 
o espaçamento de sulcação foi de $1,40 \mathrm{~m}$ e a adubação de plantio constou de 500 kg/ha da fórmula 5-25-20 aplicados diretamente nos sulcos.

Como mudas, foram distribuidas = canas, cruzadas, para divisão em toletes nos sulcos, toteìzando 7 a 8 t/ha.

Para o controle das ervas danirs gado herbicida nas dosagens e modalidades cons

Em maio, foi realizada uma oper com cultivador de discos, chegando terra à li-ha de cana.

A complementaȩão da adubação ni z=ogenada foi feita em agosto, com 250 kg/ha de Sulfato de de $N$.

\subsubsection{Primeiro Corte - Produção}

0 corte da cana-planta foi realizado manualmen te com cana queimada em 16/10/1975, tendo-se c cuidado de se rem retiradas amostras de caña antes da queim para as análi ses tecnológicas, cujos resultados constam da tabela 5 . Es sas análises foram feitas nos próprios laborazうrios da Usina Tamoio, segundo“MEADE (1967).

Para as avaliações da produção, foram casualizadas 12 cargas de veículos convencionais de zranspore, abrangendo a área com o experimento. Medidos as comprimentos das leiras com ruas que continham a carga de こ̇da veículo, foram obtidas as produções das parcelas ou rEミミミtições. As pesagens dos veículos foram feitas na balanç je recebimento de cana, no páteo da usina.

A. contagem da população de colr: s foi providen ciada durante a operação de corte manual. A que as amostragens abrangessem a área previstミ, eram casuali zados pontos de trabalho e recomendados aos č̃ cessários cuidados durante o corte na área er č̃o demarcada. Foram tomadas parcelas de 30 metros com 4 rus s, somando $168 m^{2}$ 

TABELA 5 - Análises tecnológicas obtidas em amostras de 10 colmos, na data do corte da cana-planta - com 19 meses.

\begin{tabular}{|c|c|c|c|}
\hline Repetição & Brix & Pol da & Pureza \\
\hline 1 & 18,78 & 16,79 & 89,40 \\
\hline 2 & 18,51 & 16,47 & 88,98 \\
\hline 3 & 18,45 & 16,42 & 89,00 \\
\hline 4 & 18,53 & 16,75 & 90,39 \\
\hline 5 & 17,96 & 15,98 & 88,97 \\
\hline 6 & 18,58 & 16,54 & 89,02 \\
\hline 7 & 18,12 & 15,87 & 87,58 \\
\hline 8 & 17,88 & 16,04 & 89,71 \\
\hline
\end{tabular}


TABEla 6 - Produção da cana-planta, a partir de parcelas com $168 \mathrm{~m}^{2}$.

\begin{tabular}{|c|c|c|c|c|}
\hline \multirow{2}{*}{ Repetição } & & \multirow{2}{*}{ Hectare } & \multicolumn{2}{|c|}{ Colmos } \\
\hline & & & $\begin{array}{c}N^{8} \mathrm{p} / \text { metro } \\
\text { de sulco }\end{array}$ & $\begin{array}{l}\text { Peso } \\
\text { kg }\end{array}$ \\
\hline 1 & & 111,19 & 10,7 & 1,455 \\
\hline 2 & & 119,76 & 11,3 & 1,479 \\
\hline 3 & & 115,12 & 10,9 & 1,482 \\
\hline 4 & & 112,74 & 11,1 & 1,426 \\
\hline 5 & & 112,02 & 10,9 & 1,435 \\
\hline 6 & & 124,64 & 11,5 & 1,517 \\
\hline 7 & & 120,59 & 11,7 & 1,447 \\
\hline 8 & & 110,48 & 10,7 & 1,450 \\
\hline 9 & & 110,83 & 10,8 & 1,439 \\
\hline 10 & & 112,26 & 11,0 & 1,432 \\
\hline 11 & & 121,55 & 11,8 & 1,443 \\
\hline 12 & & 116,19 & 11,6 & 1,404 \\
\hline Média & & 115,61 & 11,17 & 1,451 \\
\hline$s(\bar{m})$ & & 1,40 & 0,10 & 0,010 \\
\hline C.V. \% & & 4,21 & 3,58 & 2,069 \\
\hline
\end{tabular}


cada repetição.

A tabela 6 apresenta os parámetros referentes às pesagens obtidas da cana-planta.

\subsubsection{Transporte da Cana-Planta}

A entrada de qualqueir veículo mesmo para amostragens, só foi permitida depois de cortadas ás canas de to da a área previamente escolhida.

Após devidamente localizadas e.demarcadas as faixas que conteriam os tratamentos e as bordaduras, foi o tráfego dos veículos orientado para percorrerem somente nes tas últimas, evitando interferéncia na área do experimento por efeito de compactação.

Apenas o trator com a carregadeira entrou sobre a área útil, por ser considerada desprezível sua compactação no solo, sob o ponto de vista prático.

\subsection{Delineamento Experimental}

Ante o interesse em desenvolver o trabalho so bre a cultura em regime de campo, usando um veículo e respec tiva carga representativa do transporte convencional, optou- se pela disposição dos tratamentos de compactação em faixas.

O delineamento utilizado foi o de parcelas sub divididas, sendo as parcelas dispostas em blocos casualizados, com 4 tratamentos (compactação) e 4 sub-tratamentos(des compactaçãol, com 3 repetiçães, conforme segue:

\subsubsection{Tratamentos}

Foram 16 os tratamentos, sendo 4 de compactação e 4 de subsolagem, assim distribuidos: 
4.4.1.1. Tratamentos de Compactação

$$
\begin{aligned}
& \text { A - Testemunha (não compactada) } \\
& \text { B - uma passada do veículo } \\
& \text { C - duas passadas do veículo } \\
& \text { - trés passadas do veículo }
\end{aligned}
$$

\subsubsection{Tratamentos de Descompactação}

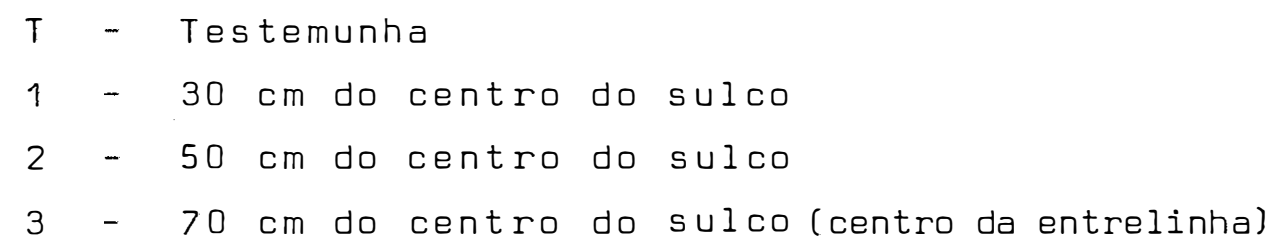

4.4.2. Repetições

Foram planejadas e realizadas 3 repetições pa ra cada tratamento, num total de 48 parcelas.

4.4.3. Parcelas

Cada parcela constou de 5 linhas de cana. As 3 ruas centrais foram consideradas üteis, ficando as 2 linhas externas de cada parcela como bordadura.

$$
\text { Com } 30 \mathrm{~m} \text { de comprimento nas linhas de cana, re }
$$
dundaram nas seguintes áreas por parcela:

$\begin{array}{llr}\text { Area util } & - & 126 \mathrm{~m}^{2} \\ \text { Bordaduras } & - & 84 \mathrm{~m}^{2} \\ \text { Area total - } & 210 \mathrm{~m}^{2}\end{array}$


A tabela 7 contém os tratamentos com as repeti ções e respectivas parcelas.

\subsubsection{Esquema de Campo}

As operações de compactação realizadas em ní vel, em obediência ao plantio, abrangeram todo o comprimento das ruas de cana, entre 2 carreadores.

Cada faixa contendo um tratamento de compactação contou com 10 linhas de cana, de forma que as 2 ruas danificadas durante o transporte da cana cortada, recairam $\bar{s}$ sobe as bordaduras externas da faixa.

Deixando as bordaduras de cabeceiras, foram de marcadas as parcelas com 30 metros de comprimento e caminhamento de 3 metros de largura, suficientes para as manobras do trator de pneumático com o implemento para os tratamentos de subsolagem.

A figura 1 mostra o mapeamento do campo.

4.4.5. Anālises Estatisticas

Os dados foram analisados segundo o esquema se guinte:

\begin{tabular}{lc} 
COEFICIENTE DE VARIAÇAO & G.L. \\
\hline BLOCOS & 2 \\
COMFACTAÇÁ & 3 \\
RESIOUD (a) & 6 \\
\hline DESCOMPACTAÇAO & 3 \\
COMPACATAÇAO $\times$ DESCOMPACTAÇAO & 9 \\
RESTOUO (O) & 24 \\
\hline TOTAL
\end{tabular}



ABELA 7 - Mapa do experimento com os tratamentos e respectivas parcelas.

\begin{tabular}{|c|c|c|c|c|c|}
\hline \multirow{2}{*}{ Passadas } & \multicolumn{2}{|c|}{ Tratamentos } & \multicolumn{3}{|c|}{ Parcelas } \\
\hline & & & Rep. I & Rep. II & Rep. III \\
\hline \multirow{4}{*}{ Test. } & $(T)$ & 0 & 9 & 25 & 33 \\
\hline & (1) & 30 & 1 & 17 & 41 \\
\hline & (2) & 50 & 2 & 18 & 34 \\
\hline & (3) & 70 & 10 & 26 & 42 \\
\hline \multirow{4}{*}{1} & $(T)$ & 0 & 7 & 23 & 39 \\
\hline & (1) & 30 & 15 & 31 & 47 \\
\hline & (2) & 50 & 8 & 32 & 40 \\
\hline & ( 3 ) & 70 & 16 & 24 & 48 \\
\hline \multirow{4}{*}{2} & $(T)$ & 0 & 13 & 21 & 37 \\
\hline & (1) & 30 & 5 & 29 & 45 \\
\hline & (2) & 50 & 6 & 22 & 38 \\
\hline & $(3)$ & 70 & 14 & 30 & 46 \\
\hline \multirow{4}{*}{3} & $(T)$ & 0 & 11 & 27 & 35 \\
\hline & (1) & 30 & 3 & 19 & 43 \\
\hline & (2) & 50 & 4 & 20 & 36 \\
\hline & ( 3 ) & 70 & 12 & 28 & 44 \\
\hline
\end{tabular}




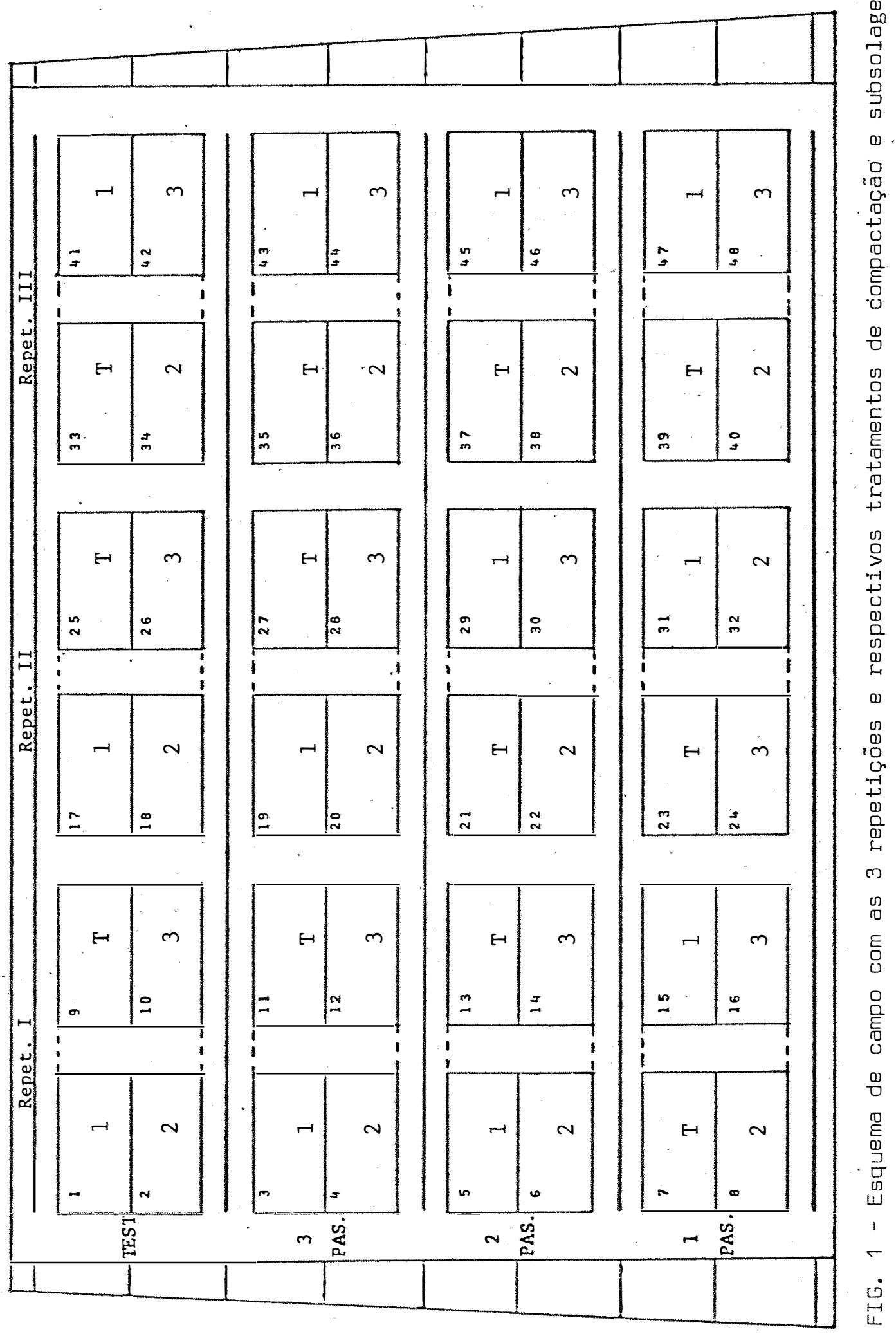




\subsection{Veĩculo compactador do solo}

Em se tratando de um trabalho a ser desenvolvi do de forma a reproduzir o que ocorre no próprio campo, o veículo utilizado na tarefa de compactação do solo deveria oferecer as mesmas características do veículo convencional de transporte de cana e desempentiar idênticas funções na área em cultivo.

Obviamente os aspectos mais importantes deve riam ser representados pelos rodados dianteiro e trazeiro, bem como sua carga em movimento.

Assim sendo, o caminhão carregado com cana com um só eixo trazeiro, foi substituido por outro caminhão, tam bém com um só eixo no rodado trazeiro, transportando areia..

\subsubsection{Características do veículo}

Caminhão marca Ford F7, diesel, modelo basculante, série 1975, com pneumáticos de dimensões originais e pressões internas adequadas a trabalho. A figura 2 mostra as medidas do rodado trazeiro do caminhão convencional utili zado .

4.5.2. Distribuição da carga

0 veículo com carga de areia apresentou peso total de $14.785 \mathrm{~kg}$, distribuidos $2.514 \mathrm{~kg}$ no rodado diantei ro e 12.271 kg sobre o eixo trazeiro.

Segundo FURLANI NETO et alie (1978), um veículo com semelhantes medidas no rodado trazeiro, sobre o qual recairam $12.335 \mathrm{~kg}$ como parte da carga total, apresentou uma pressão na superfície do solo de $5,06 \mathrm{~kg} / \mathrm{cm}^{2}$. 


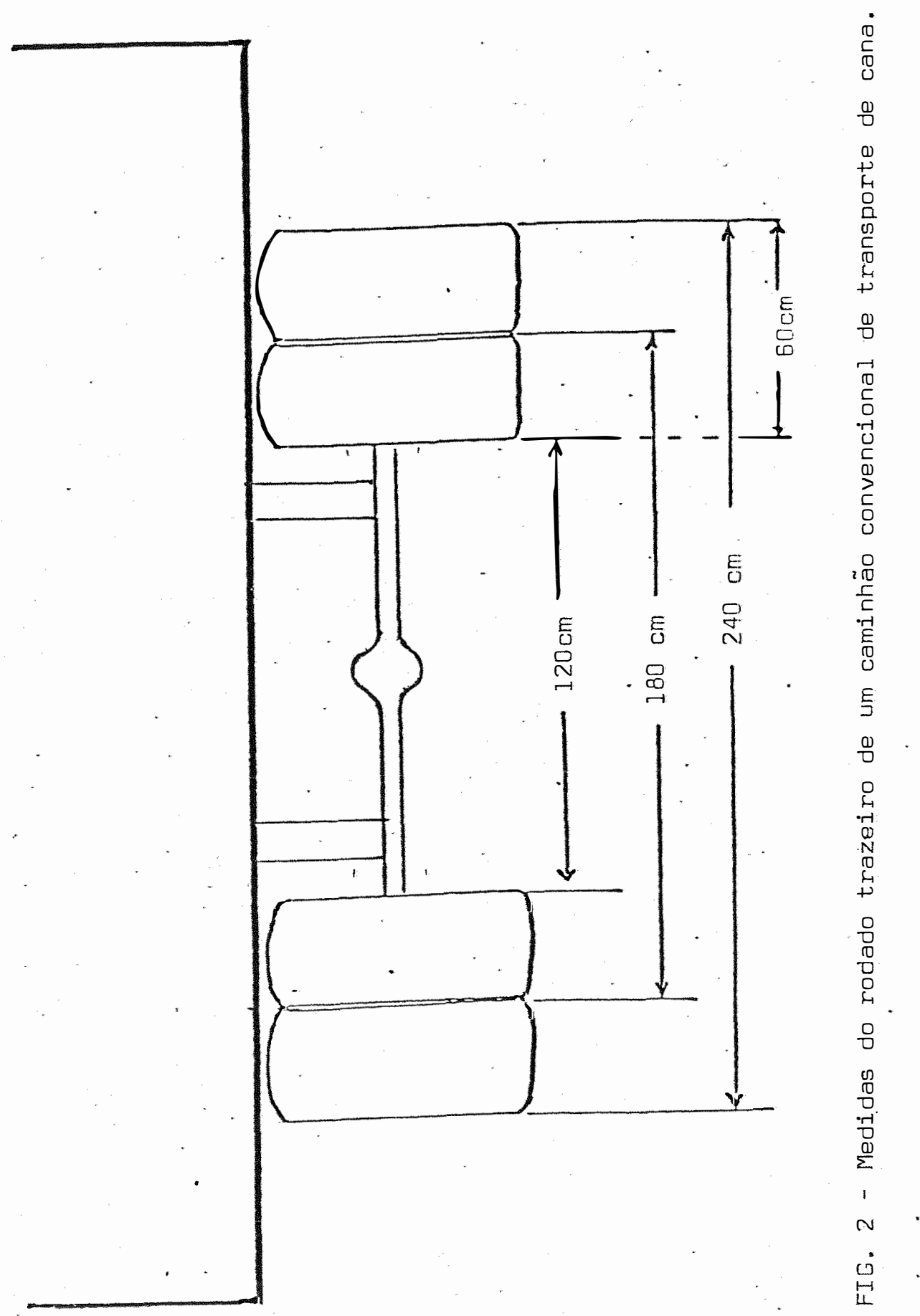




\subsection{Implemento Descompactador}

Para as operações de descompactação do solo foi preparado um implemento de hastes que se convencionou chamar de subsolador alado. Conforme mostra a figura 3 , em cada haste foram aplicados 2 pares de pequenas asas, com a finali dade de proporcionar mais adequado trabalho na área a ser ocupada pelo novo sistema radicular.

Como a subsolagem atingiria a profundidade de $25 \mathrm{~cm}$, o primeiro par de asas foi aplicado na extremidade in ferior da haste e o segundo a $12,5 \mathrm{~cm}$ de profundidade.

\subsection{Preparo da ārea para o experimento}

Uma vez retirada toda a produção, foi providen ciada a limpeza do palhiço restante. Para tanto, com o auxí lio de enxadas, o palhiço foi enleirado nas faixas reservadas para a passagem dos veículos de transporte durante a re tirada da cana colhida.

Dessa forma as faixas onde se localizaram os tratamentos permaneceram com as condições físicas do solo sob as quais se desenvolveram as plantas durante o ciclo do primeiro corte:

\subsection{Processos operacionais de campo}

4.8.1. Canaletas para amostragem do solo

De chapa de alumínio com $4 \mathrm{~mm}$ de espessura, fo ram confeccionadas canaletas com a forma e dimensões mostradas na figura 4.

Os bordos tornados cortantes facilitaram a pe netração no solo através de pressão lentá e constante, objetivando amostras indeformadas (monolitos). 


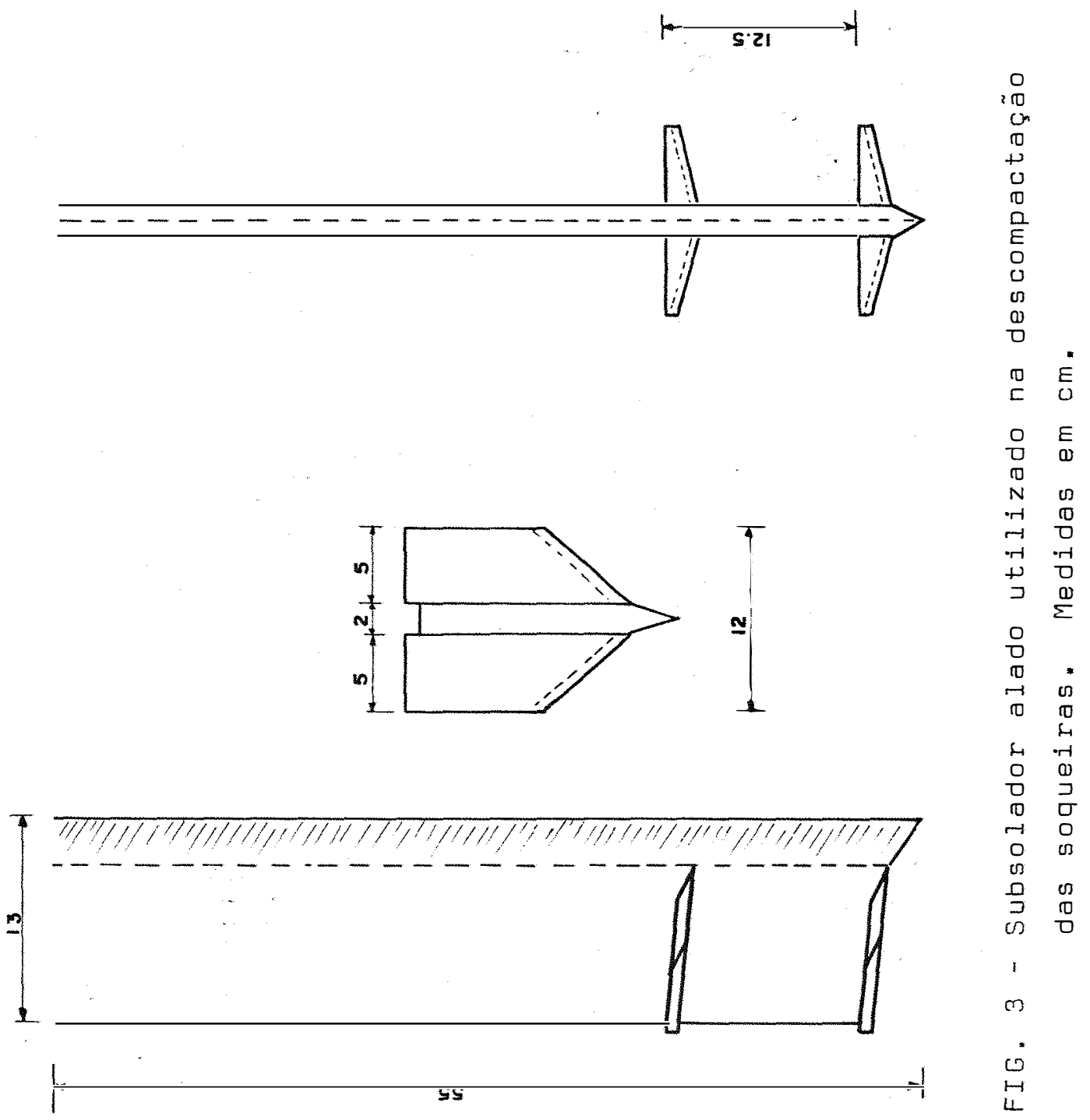




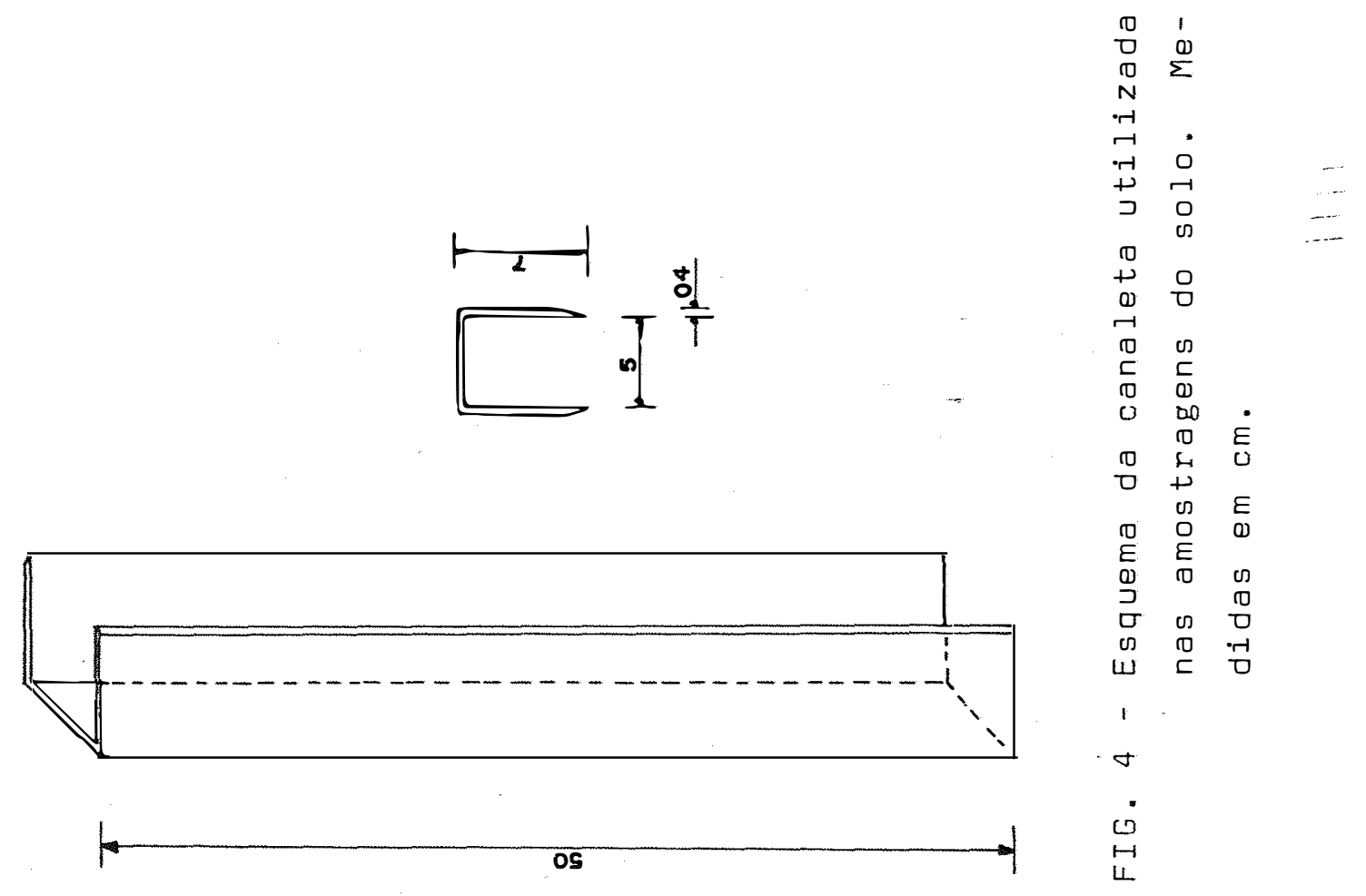


A superposição de 2 canaletas em 2,5 cm no sentido vertical permitiu as medidas sucessivas cada $5 \mathrm{~cm}$ do perfil do solo.

Cada canaleta continha na face posterior as in dicações de sua respectiva posição na trincheira.

\subsubsection{Trincheiras}

Definido que seriam analisadas as densidades aparentes nos perfís do solo até à profundidade de $90 \mathrm{~cm}$ e retiradas amostras em 3 locais equidistantes, isto é, no cen tro da linha de cana, a $35 \mathrm{~cm}$ e $70 \mathrm{~cm}$ lesta última na entreli nha), cada trincheira foi aberta com dimensões suficientes para o fácil trabalho manual dos dispositivos de amostragem.

\subsubsection{Compactação do solo}

Comoos dois pneumáticos trazeiros em cada lado do veículo contaram com a largura de 60 cm na faixa de apoio no solo e o espaço medido nos centros dos 2 pares de pneus resultou em $1,80 \mathrm{~m}$, (figura 2 ) esses valores levaram à opção pela compactação em área total, como uma forma de ser conseguida uniformidade no trabalho.

\subsubsection{Obtenção da umidade no solo}

Antes de serem executadas as operações de compactação, foram retiradas amostras do solo, em número de 8 repetições, para conhecimento dos niveis de umidade do solo. As amostras foram colhidas à profundidade de $45 \mathrm{~cm}$, sendo uniformizadas e retirada uma aliquota para a avaliação da umidade que foi realizada pelo método convencional da estufa a $110^{\circ} \mathrm{C}$ por 48 horas. A tabela 8 contém os teores encontrados. 
$\begin{aligned} \text { TABELA } 8 \text { - } & \text { Umidade no solo até } 45 \mathrm{~cm} \text { de } \\ & \text { profundidade, obtidas no ato } \\ & \text { das operações de compactação. }\end{aligned}$

\begin{tabular}{|c|c|}
\hline Amostras & Teores \\
\hline la. & 31,68 \\
\hline $2 a$. & 31,99 \\
\hline 3a. & 32,60 \\
\hline $4 a$. & 31,14 \\
\hline $5 a$. & 32,53 \\
\hline $6 a$. & 32,16 \\
\hline 7a. & 31,94 \\
\hline $8 a$. & 32,84 \\
\hline Soma & 256,88 \\
\hline Média & 32,11 \\
\hline
\end{tabular}




\subsubsection{Amostragens para as densidades de compactação}

As amostras para conhecimento da compactação causada pelo veículo de transporte foram retiradas após as subdivisões da área em parcelas.

\subsubsection{Obtenção das Amostras}

Para a penetração das canaletas no solo de for ma a não provocar deformações na condição estrutural do solo, foi utilizado um macaco hidráulico de manejo manual. Sua parte trazeira apoiou-se em uma base suficientemente resistente (vigota $16 \times 6 \mathrm{~cm}$ ), encostada verticalmente na parede posterior da trincheira.

Entre a canaleta e a parte anterior do macaco, um dispositivo de madeira (caibro) serviu ao mesmo tempo de apoio e distribuição do esforço de impulsão contra a primeira, ao longo do seu comprimento.

Movimentos lentos e compassados provocaram a penetração da canaleta no solo, cuja regularidade e precisão dependeram apenas dos cuidados operacionais.

Uma vez retirada, cada canaleta foi devidamente limpa e colocada em um saco plástico com dimensões pouco superiores à da própria amostra, de forma a ser fechado com a menor quantidäde possível de ar internamente.

As canaletas assim preparadas e etiquetadas permaneceram à sombra e protegidas por período de 20 dias, para a melhor uniformidade possível da umidade, que afeta a determinação da densidade do solo, feita neste estudo pela técnica da atenuação da radiação gama, descrita adiante.

Foram retiradas 72 canaletas de 12 trincheiras. 
4.8.3. Descompactação do solo

O subsolador alado, descrito no item 4.6. foi aplicado logo após retiradas as amostras para as análises da compactação. Um trator de pneumático com suspensão hidráuli ca de 3 pontos, tracionou o implemento agindo à profundidade de $25 \mathrm{~cm}$ e em ambos os lados da linha.

4.8.3.1. Amostragens para as densidades apos descompac$\operatorname{taçãa}$

A segunda série de amostragens para a avaliaçãó das condições físicas do solo, sob as quais se desenvolveram as raízes, foi executada logo após o corte da cana-soca.

Nesse caso, as trincheiras foram abertas dentro da respectiva parcela de forma a abranger a linha central e a entrelinha do lado direito.

Tendo sido programadas 3 repetições também para ambos os tratamentos de compactação e de subsolagem, foram retiradas. 288 canaletas de 48 trincheiras.

\subsubsection{Obtenção das Amostras}

o método de obtenção das amostras foi o mesmo seguido para a compactação.

4.9 Anāi ises das densidades das amostras

As análises de densidade do solo das amostras foram realizadas pelo método de atenuação de raios gama, em colaboração com o Centro de Energia Nuclear na Agricultura, de Piracicaba, Estado de São Paulo. 
Como fonte de raios gama foi utilizado ${ }^{137} \mathrm{Cs}$, obtendo-se a densidade do solo segundo metodologia descrita por FERRAZ (1974) e obedecendo a técnica seguinte:

\section{A - Preparo das Canaletas.}

Levadas para a sala de análise,as 2 canaletas correspondentes a cada local amostrados foram retiradas das embalagens e assinalados a cada.5 cm, os pontos a serem atravessados pelo feixe de raios gama.

B - Obtenção da leitura

Devidamente preparados os instrumentos e antes de ser iniciada a análise de cada amostra, foi

feíta uma leitura Io, utilizando uma canaleta sem solo para avaliar a absorção de raios gama pelo metal da canaleta.

Em seguida era medida a canaleta contendo o so 1o, focalizando cada ponto previamente demarcado.

A canaleta era posicionada de maneira que o feixe de radioatividade atingia o ponto intermediário da altura, isto é, $3,5 \mathrm{~cm}$.

Para cada leitura foi definido o tempo de 30 segundos .

o Anexo I mostra o modelo utilizado para as anotações dessas leituras e de outros parámetros a serm abor dados.

C - Espessura da amostra

Após essas leituras, foram obtidas as medidas correspondentes à espessura da camada do solo em cada um dos pontos analisados. Essa espessura, que cons titue fator importante no cálculo da massa sólida atravessada pelos raios gama, pode sofrer alterações durante a operação de amostragem de solo, pelo fechamento ou abertura das paredes da canaleta. 
D - Teores de ägua no solo das canaletas.

A água contida no solo também constitue fator de absorção da radiação gama utilizada nas me didas de densidade do solo. Porisso foram retiradas de cada canaleta, 2 líquotas de solo para a avaliação da umidade.

Tais avaliações foram feitas pelo método tradicional da estu fa a $110^{\circ} \mathrm{C}$ por 48 horas. Os valores eram anotados também no anexo I.

\section{Cálculos da denșidade do solo}

De posse das informações contidas no anexo I, a densidade do solo em cada ponto analisado foi obtida atra vés da expressão abaixo, considerada desprezível a absorção pelo ar contido no solo:

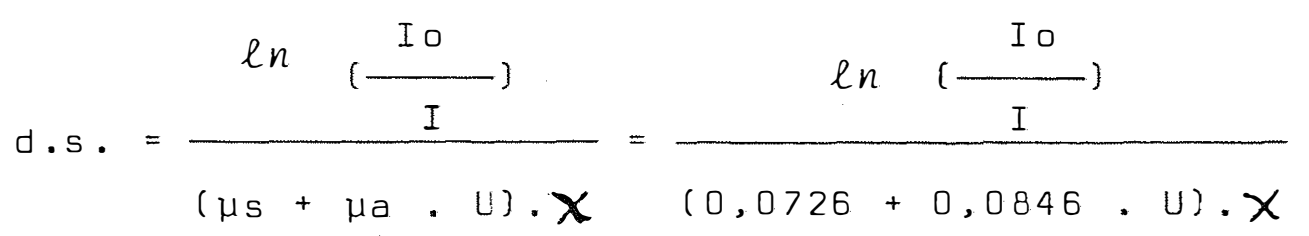

sendo:

$$
\begin{aligned}
& d s=\text { densidade do solo }\left(\mathrm{g} \cdot \mathrm{cm}^{-3}\right) \\
& \text { Io = leitura da calha sem o solo (contagens por minu- } \\
& \text { to, cpm) } \\
& \text { I = leitura da calha com o solo (contagens por minu- } \\
& \text { to, cpm) } \\
& \mu s=\text { coeficiente de absorção do solo ao }{ }^{137} \mathrm{Cs}=0,0726 \\
& \left(\mathrm{~cm}^{2} \cdot \mathrm{g}^{-1}\right) \\
& \mu a=\text { coeficiente de absorção da ägua ao }{ }^{137} \mathrm{Cs}=0,0846 \\
& \left(\mathrm{~cm}^{2} \cdot \mathrm{g}^{-1}\right) \\
& U=\text { umidade do solo em (g/g) } \\
& X \text { = espessura da amostra no ponta da leitura (cm) } \\
& \ln =\text { logaritmo neperiano }
\end{aligned}
$$

Para cada ponto analisado, levou-se em conta como teor de água, a média dos valores obtidos para as 2 
alíquotas da respectiva canaleta.

Transportados os resultados para a coluna das Densidades, no anexo I, obteve-se a compactação verificada nos vários pontos do perfil do solo para cada posicionamento de 2 canaletas correspondentes.

4.10. Colheita do experimento

4.10.1. Anālises tecnológicas

-....

Antecedendo a colheita, foram retiradas amos tras de colmos para as análises tecnológicas. De cada parce - la foram colhidas 10 canas, cortadas em linha contínua na rua central e enviadas para o laboratório da Usina, para obtenção dos valores de Brix, Polarização e Pureza.

\subsubsection{Corte}

Em 07/10/76, o experimento foi queimado na pa te da manhã para o corte manual.

Durante a operação de corte foram tomadas as providéncias com vistas aos necessários cuidados com as 3 ruas centrais das parcelas.

\subsubsection{Contagem da população}

Foram obtidas contagens dos colmos produzidos ao longo dos 30 metros das 3 linhas centrais. A esses valores foram acrescentados os 10 colmos retirados para as análi ses tecnológicas. 


\title{
4.10.4. Pesagem das produções
}

\begin{abstract}
Reunidos os colmos em montes de 100 unidades mais a fração final, foram obtidas as pesagens parciais, uti lizando-se um dinamómetro marca chatilon, com capacidade pa ra $500 \mathrm{~kg}$ e acionado pela própria carregadeira, usada conven cionalmente no carregamento dos veículos de transporte da ca na. Aos valores encontrados foram acrescentados os pesos das 10 canas enviadas ao laboratório para as análises tecnológicas.
\end{abstract}

\subsection{Estudo do sistema radicular}
objetivando estudar o comportamento do sistema radicular da cana-de-açúcar sob os diferentes tratamentos, foram feitas amostragens dos perfís do solo.

Esse trabalho foi executado em uma só repetição do experimento, tendo sido escolhidas as lo parcelas da repetição central.

\subsubsection{Amostragem}

Após retiradas as amostras dos perfís do solo para a $2 a$. série de análises sobre a descompactação, as trin cheiras foram aproveitadas para os trabalhos de amostragens destinadas aos estudos do sistema radicular.

Para isso, cada trincheira foi redimencionada de forma a permitir a retirada de amostras em uma faixa de l,40 m, abrangendo a linha de cana e a metade da entrelinha de cada lado, até à profundidade de $1,00 \mathrm{~m}$. 


\subsubsection{Dimensão e nümero de amostras}

Cada amostra constituiu-se de um cubo com 20 cm de lado. Foram portanto 35 amostras de 8 litros de ter ra para cada trincheira, somando 560 amostras retiradas, com $4,48 \mathrm{~m}^{3}$ de terra.

A figura 5 representa uma trincheira previamen te demarcada para a amostragem do solo coritendo as raízes.

\subsubsection{Preparo e pesagem das amostras}

Na medida em que eram retiradas, as amostras fㅡㅡ ram etiquetadas e transportadas para a Estação Experimental, em Araras-SP.

Dentro do período de 24 horas foram passadas uma a uma parabaldes com capacidade de 60 litros e submeti das a uma breve imersão em água para que as raizes se libertassem da terra.

Em seguida, foi transferido o material para uma peneira de malhas $0,5 \mathrm{~cm}$ com $80 \mathrm{~cm}$ de diámetros e arame $n^{\circ} 22$ em aço. Submetido à lavagem em. água sob queda natural, ficou fácil a separação da parte estranha às raizes.

Estas receberam um secamento prévio ao ar livre antes de serem embaladas em sacos de papel e levadas à estufa.

Sob a temperatura de $110^{\circ} \mathrm{C}$ por 48 horas, as em balagens foram pesadas em balanças de precisão e calculados os pesos líquidos das raízes de cada amostra. 


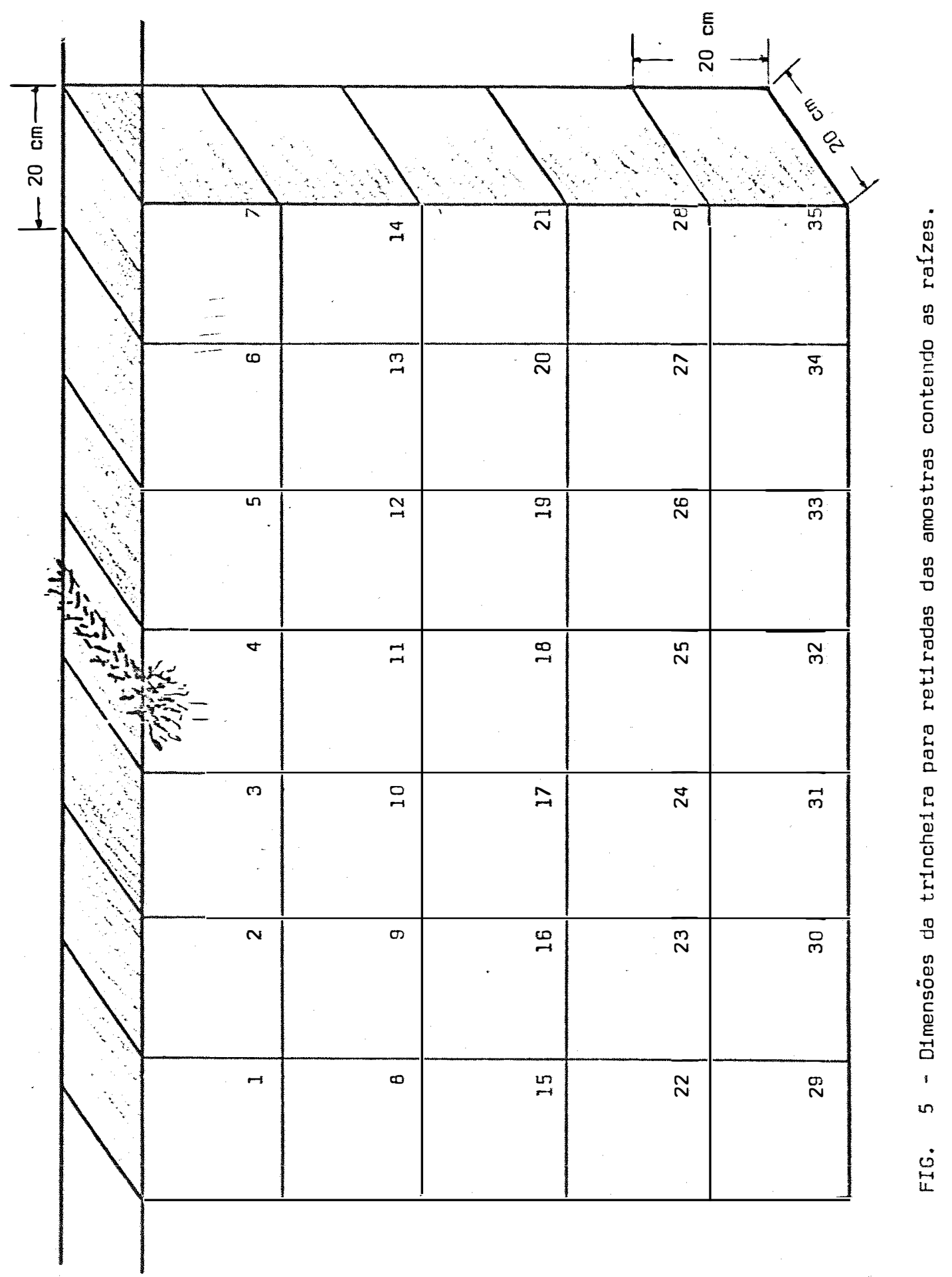




\section{RESULTADOS E DISCUSSAOO}

\subsection{Produção da cana-planta}

A produção do $1^{\circ}$ corte, anterior à instalação do experimento, consta da tabela 6, cujos resultados revelam satisfatória regularidade da área. As análises tecnológicas são mostradas na tabela 5 .

5.2. Efeito da compactação do solo

5.2.1. Umidade no solo

No ato das operações de compactação, o solo apresentava 32 , II como teor de umidade até a profundidade de $45 \mathrm{~cm}$, conforme mostra a tabela 8 . 


\subsubsection{Densidade apōs compactação}

A tabela 9 apresenta as medidas das densidades do solo após as operações de compactação, e as figuras 6, 7 , 8 e 9 mostram as representações gráficas das densidades nos 3 planos amostrados, isto é, na projeção do centro do sulco, a $35 \mathrm{~cm}$ e a $70 \mathrm{~cm}$ deste. Este último plano coincidindo com o centro da entrelinha.

Do tratamento testemunha não compactado, o sㅡ lo na projeção do sulco permaneceu com densidades próximas de 1, o de maneira uniforme, através de todo o perfil até a profundidade de $90 \mathrm{~cm}$. Esse comportamento permite admitir que as próprias raizes da cana, nos 2 ciclos agrícolas, provave 1 mente contribuiram para a manutenção dessa condição física do solo.

Pela amostragem a $35 \mathrm{~cm}$ a partir do centro do sulco, correspondendo portanto, a 20-25 cm afastados da linha da soqueira, nota-se um adensamento do solo, com ponto máximo a $25 \mathrm{~cm}$ de profundidade. Provavelmente trata-se da perco lação das menores partículas a partir das camadas superiores. Enquanto isso, no centro da entrelinha esse adensamento se mostra mais caracterizado, alcançando densidade 1,2. Na pro fundidade de 40-45 cm as densidades do solo tenderam a ser equivalentes nos 3 planos amostrados, permanecendo entre 1,0 e 1,1 .

As pesquisas realizadas por OLIVEIRA et alii

$(1968)$, levaram a essas conclusões sobre o adensamento dos so los de tabulaeiros do Nordeste, após contínuos cielos culturais.

o tratamento com 1 passada do veículo em área total, apresentou semelhantes condições de densidade ao longo dos 3 perfís amostrados até à profundidade de $90 \mathrm{~cm}$. Cum pre observar os pontos de máxima compactação, localizados en tre 30 e $35 \mathrm{~cm}$ do nível do solo, cujas densidades alcançaram indices de 1,20 no centro do sulco, ultrapassando l,26 na en trelinha. O retorno dos índices de densidades aos valores 


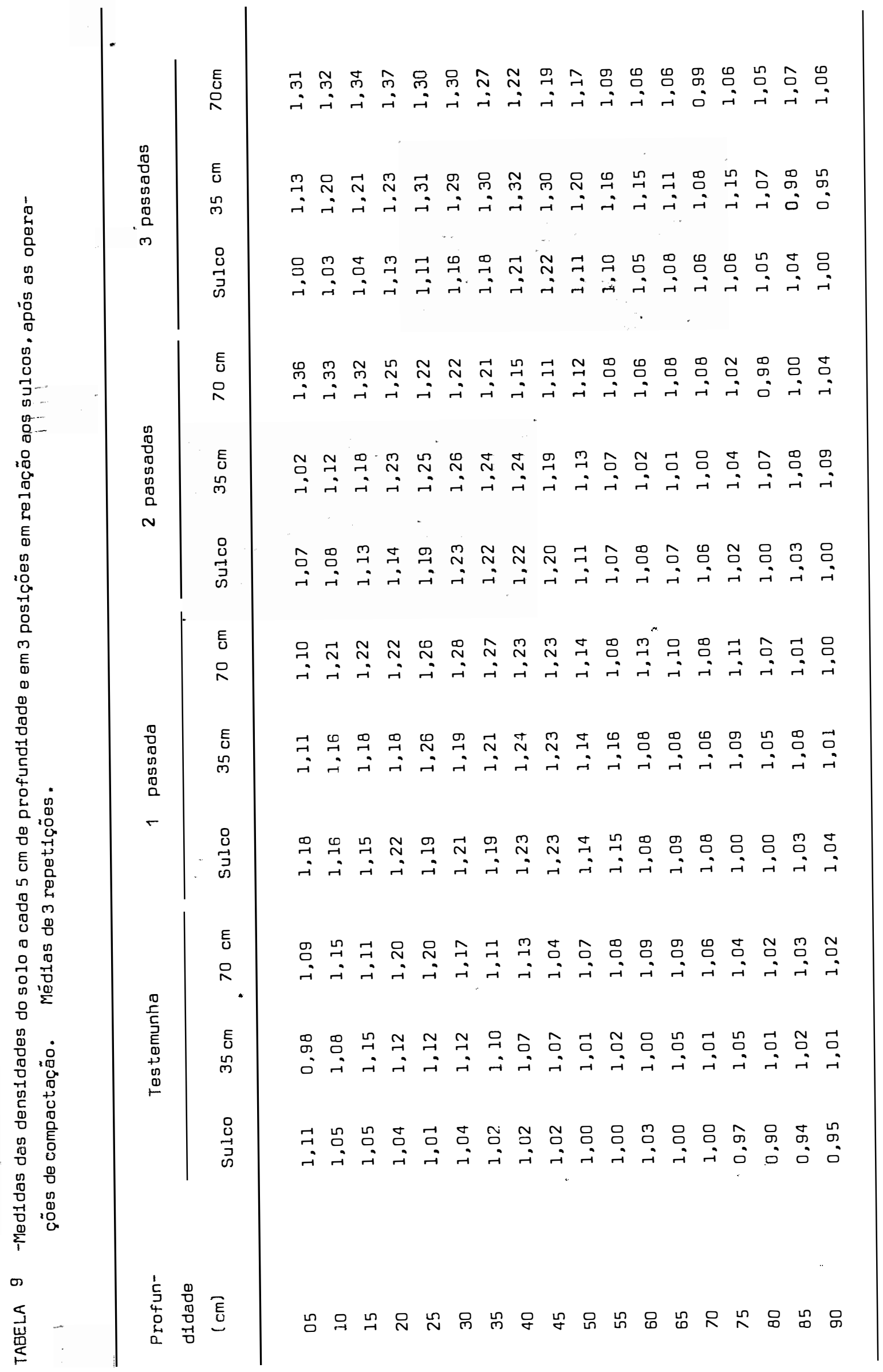




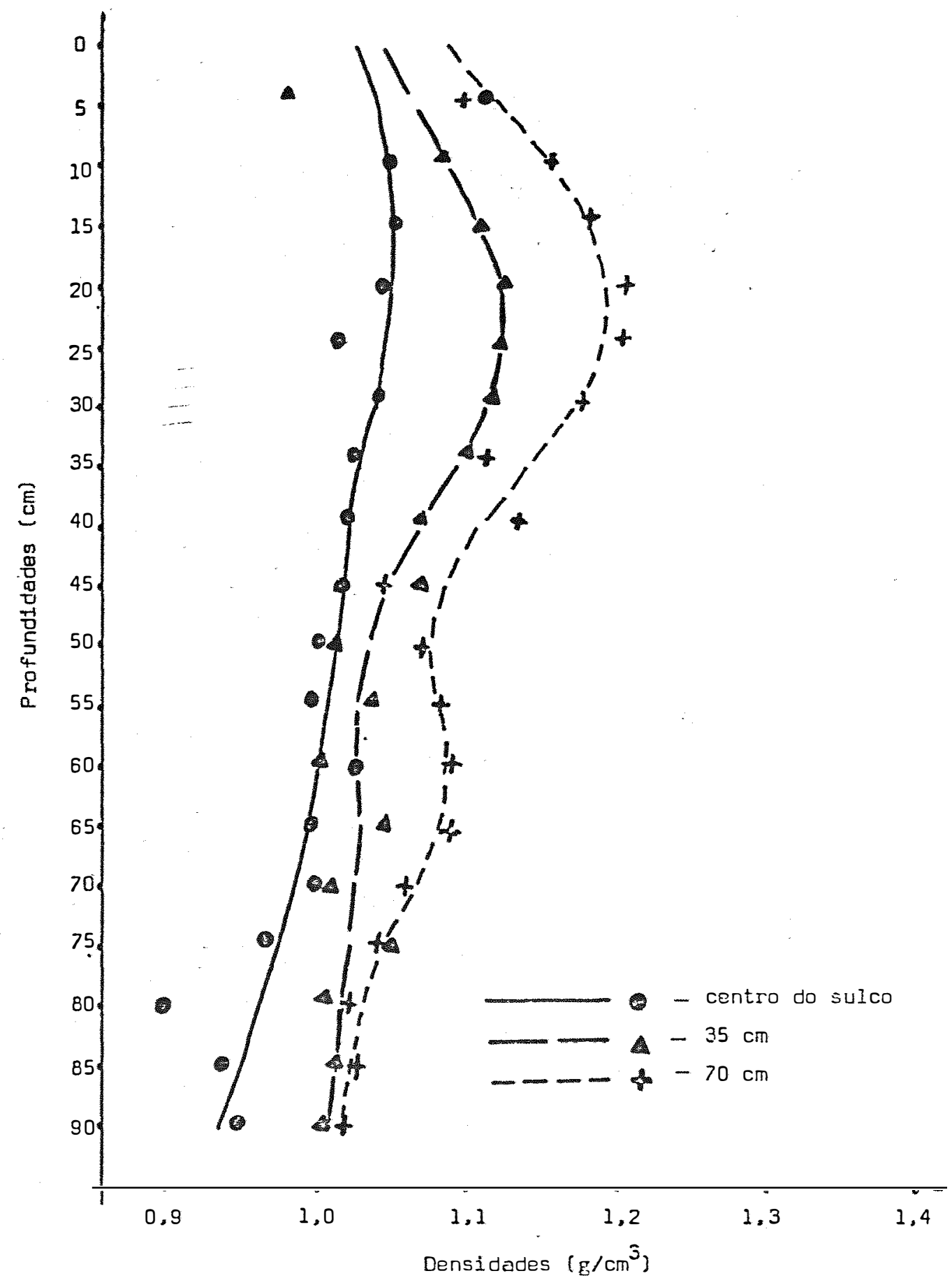

FIG. 6 - Representaçāo das densidades do solo nos 3 planos do perfíl até $90 \mathrm{cn}$ de profundidade, na ärea näo compactada. 


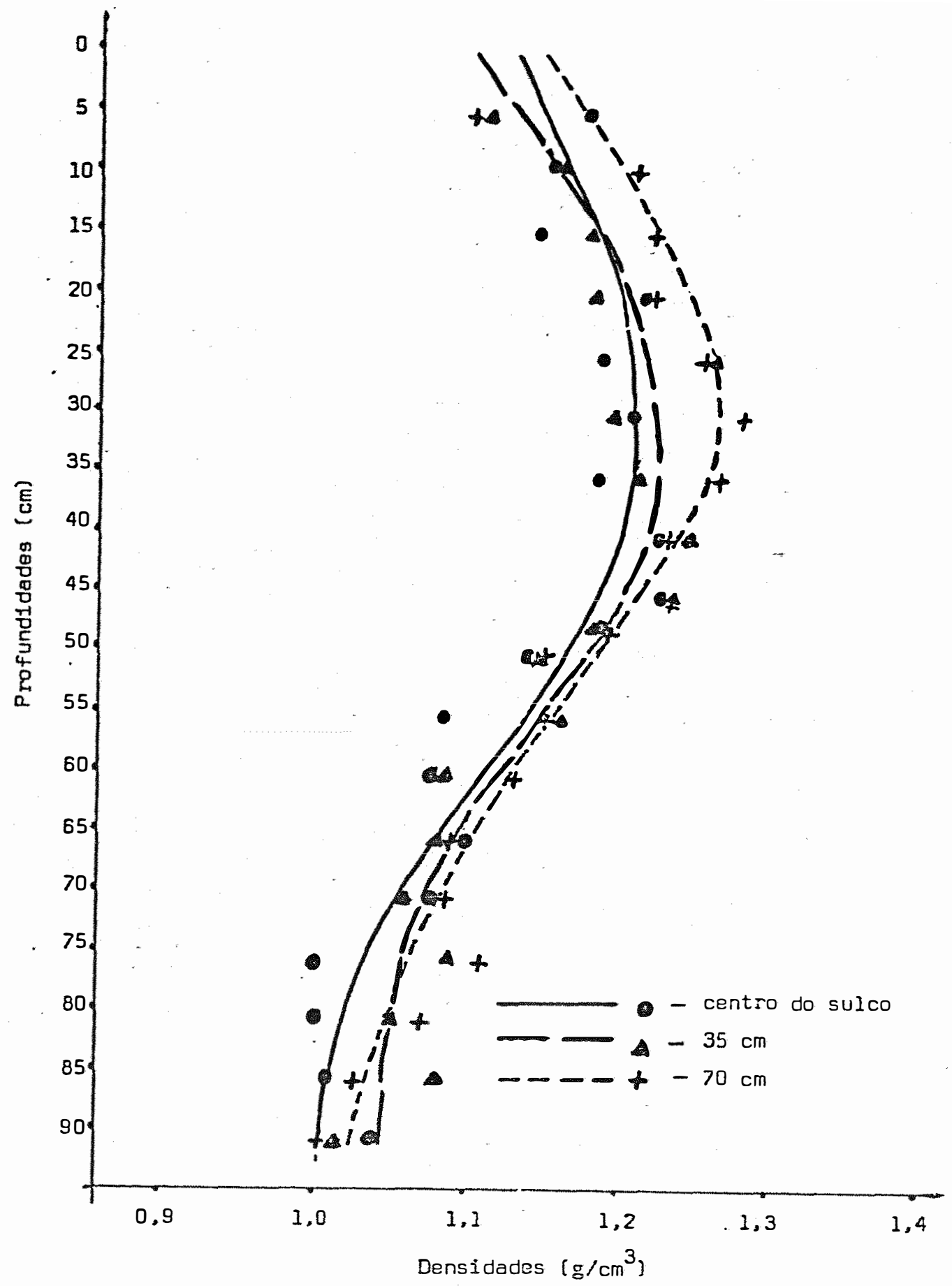

FIG. 7 - Representaçāo das densidades do solo nos 3 planos do perfíl até $90 \mathrm{~cm}$ de profundidade, apös a compactaçăo da área com 1 passada do veículo. 


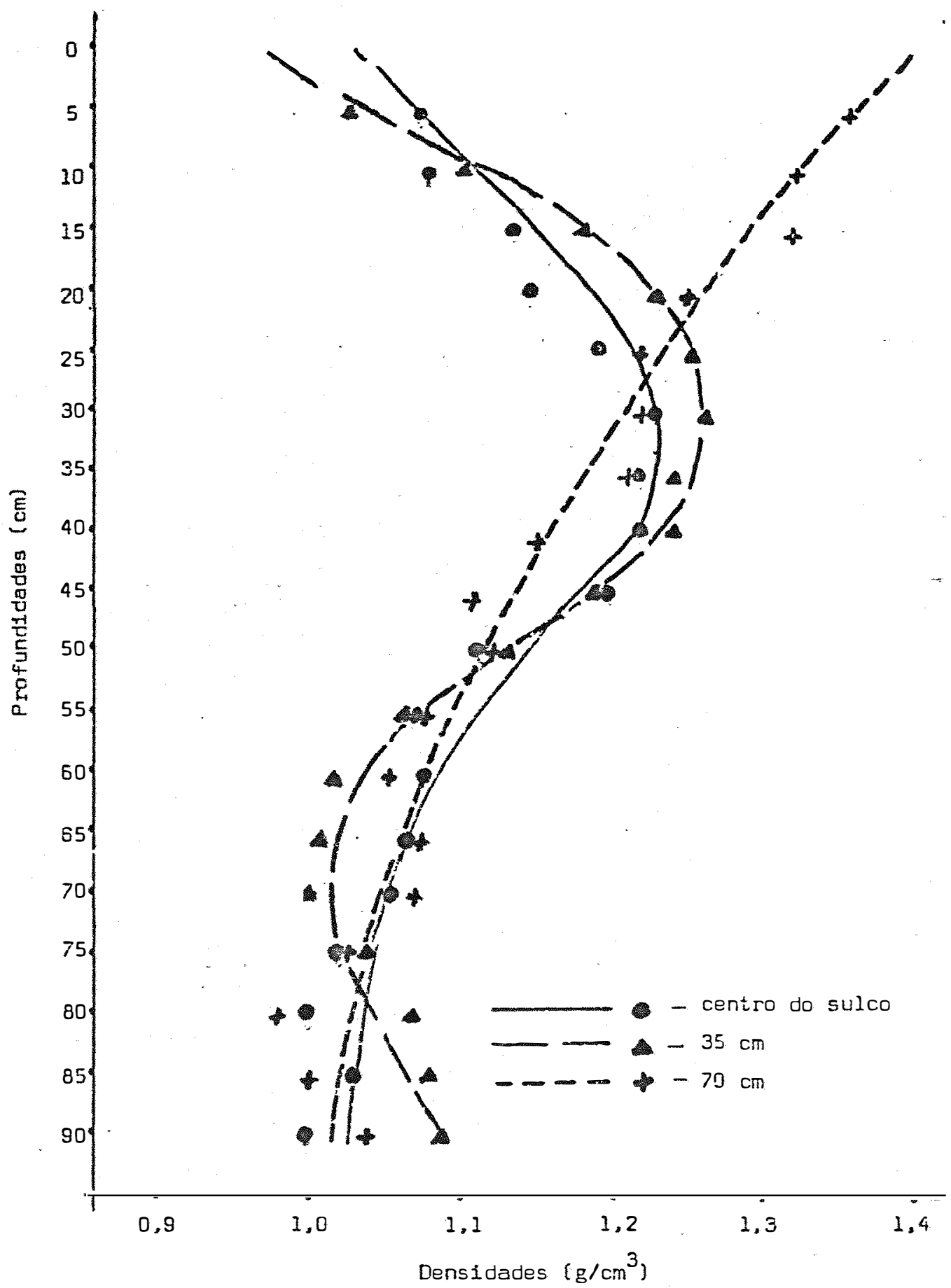

FIG. 8 - Representaçäo das densidades do solo nos 3 planos do perfíl até $90 \mathrm{~cm}$ de profundidade, apös a compactaçāo da ärea com 2 passadas do veículo. 


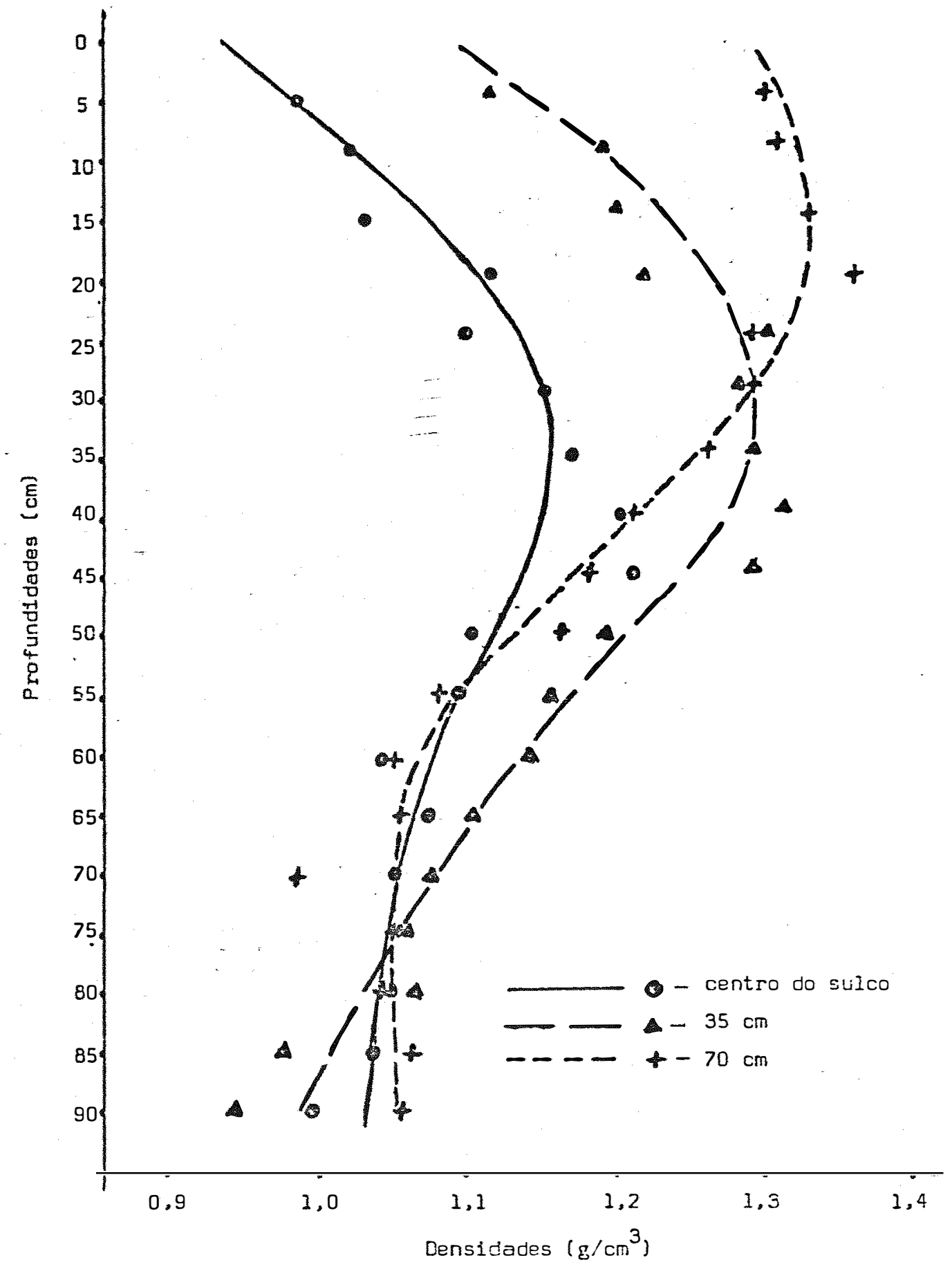

FIG. 9 - Representaçào das densidades do solo nos 3 planos do perfíl até $90 \mathrm{~cm}$ de profundidade, após a compactação da ärea com 3 passadas do veículo. 
próximos de 1,1, ocorreu aos $50-55 \mathrm{~cm}$ de profundidade.

Quanto ao tratamento com 2 passadas, apresentou características peculiares. Provavelmente, fatores devem ter influído na parte superficial do solo amostrado, já que nos 2 perfís correspondentes ao centro do sulco e a 35 cm des te, as linhas seguem a mesma trajetória através do perfil do solo, até alcançarem o ponto de máxima densidade, a 35 cm da superfície. Esse ponto é comum para os 3 planos, com índices entre 1,22 e 1,26. Também nesse tratamento o.retorno dos ín dices de densidade aos valores próximos de 1,10 ocorreu aos $50 \mathrm{~cm}$ da superfície.

0 tratamento com 3-passadas mostrou-se bastante coerente com.o comportamento esperado, em relação aos efeitos da compactação. Enquanto a faixa correspondente à projeção do sulco mostrou uma tendência a resistir aos esfor ços de compactação exercida pelo veículo, os índices de densidade foram mais acentuados na medida em que se afastou na direção da entrelinha. O ponto de maior compactação continuou ainda entre 35 e $40 \mathrm{~cm}$, como nos demais tratamentos com pactados, embora alcançando densidade 1,3, pouco mais alto que aqueles. Também o retorno às densidades próximas de 1,1 verificou-se a $55 \mathrm{~cm}$ de profundidade.

De acordo com as observações de Zelenin, citado por GILL (1968) e de Chancellor et alii, citados por LARSON \& ALLMARAS (1971), o rodado do veículo utilizado, assentando-se numa faixa de $60 \mathrm{~cm}$ de largura, deveria apresentar - ponto de máxima compactação a $30 \mathrm{~cm}$ de profundidade. As figuras 7, 8 e 9 mostram essas localizações entre 35 e 40 cm abaixo da superfície. Esses valores podem ser considerados concordantes, mormente levando-se em conta também o exposto por GILL (1959), segundo o qual, "a profundidade de compacta ção aumenta na medida em que sejam maiores as forças compactantes aplicadas". Os valores crescentes da densidade do so lo com o número de passadas, está também de acordo com a afir mação de GILL (1959) de que, "a repetição das passagens das cargas resulta em maior compactação". 


\subsection{Efeitos da subsolagem na densidade do solo}

As medidas das densidades do solo após as op $\underline{e}$ rações de compactação, constam das tabelas 10, 11, 12 e 13 , respectivamente para os tratamentos com $0,1,2$ e 3 passadas do veículo.

Essas medidas foram obtidas 12 meses após as operações de compactação, imprimindo seus efeitos sobre o com portamento do sistema radicular durante todo o ciclo agrícola. Os resultados são representados pelas figuras 10 a 25.

Confrontando as...figuras 6 e 10, isto é, ambos representando as parcelas não compactadas e também não subso ladas, observa-se que, durante o ciclo da cana houve visível adensamento das camadas superiores nos 3 planos analisados, com ligeiro destaque para a parte mais superficial do solo. Os pontos máximos de adensamento ficaram entre 15 e 20 cm de profundidade, elevando-se os índices de densidade para 1,20 na projeção do sulco e 1,25 para os planos mais próximos da entrelinha.

As operações de subsolagem a 30 e 50 cm distan tes do centro do sulco favoreceram visivelmente a faixa de solo próxima da linha de cana, conforme se observa nas figuras 11 e 12. Quanto ao tratamento subsolado a $70 \mathrm{~cm}$, mostra do na figura 13, parece não haver favorecido igualmente a fai xa contendo a soqueira, porquanto, as densidades da entrelinha permaneceram nos valores iniciais, próximos de 1,30.

Nas parcelas compactadas com uma passada doveí culo mostram como primeira característica, a elevação das densidades nas camadas superficiais do solo, alcançando valo res acima de 1,30: Por outro lado, é de se notar que nas es treitas faixas correspondentes às passagens do subsolador, os indices de densidade foram reduzidos a valores próximos de 1,00 a 1,10. Esses valores se elevaram novamente logo abaixo da área de atividade $(25 \mathrm{~cm})$ do implemento. Pode-se obser var que, na parcela não subsolada as densidades são equivalentes nos 3 planos amostrados; a parcela subsolada a $30 \mathrm{~cm}$ 


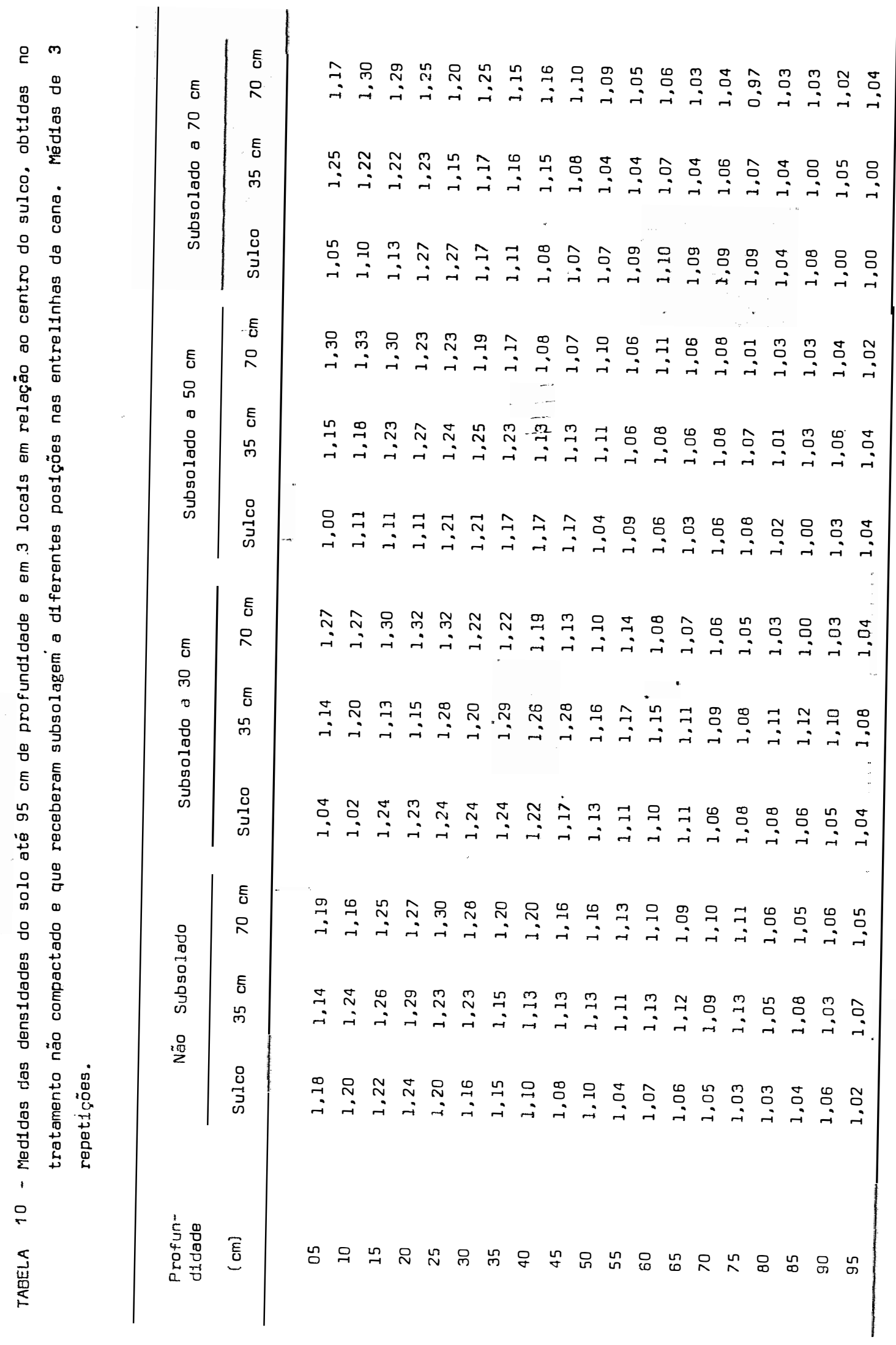




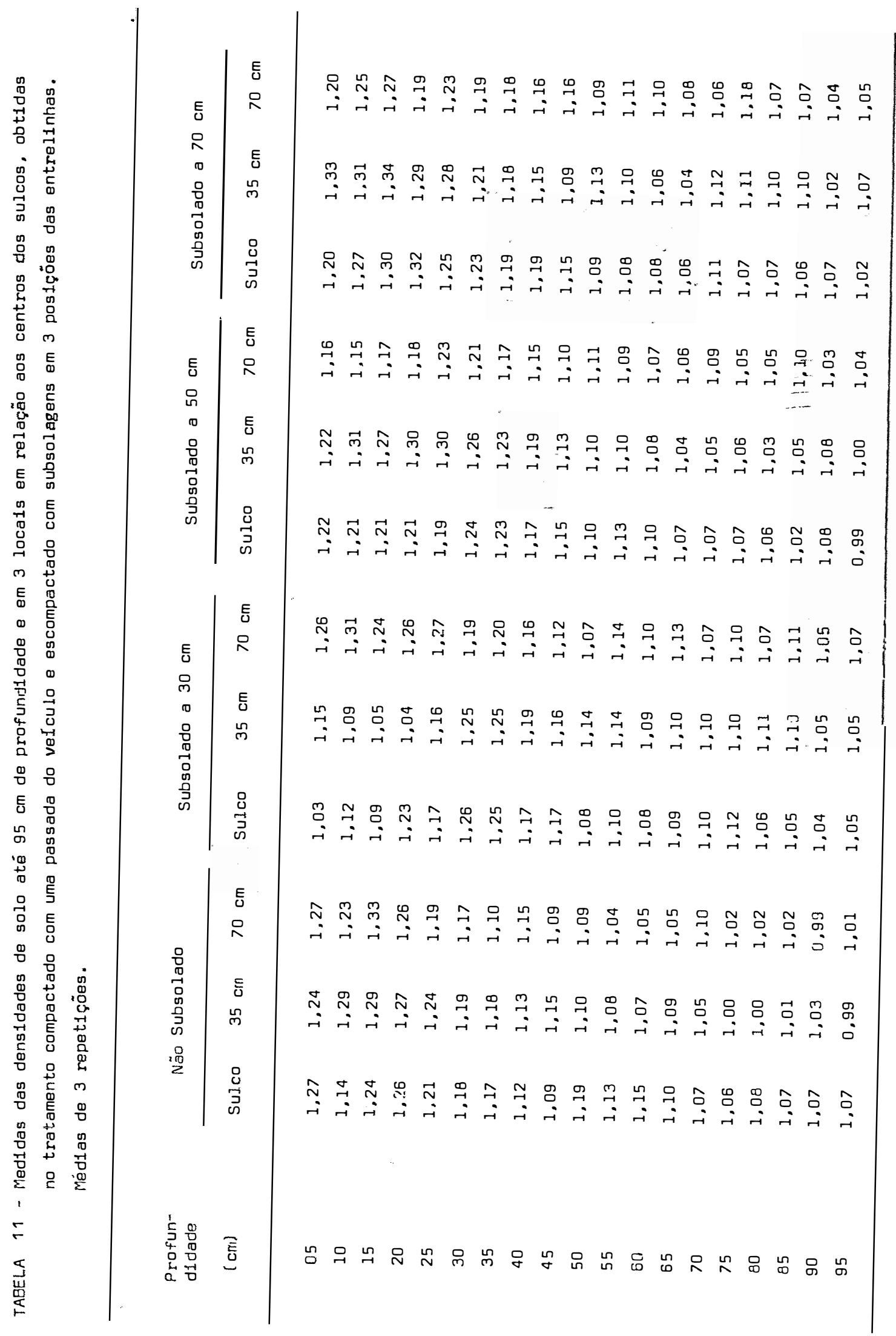




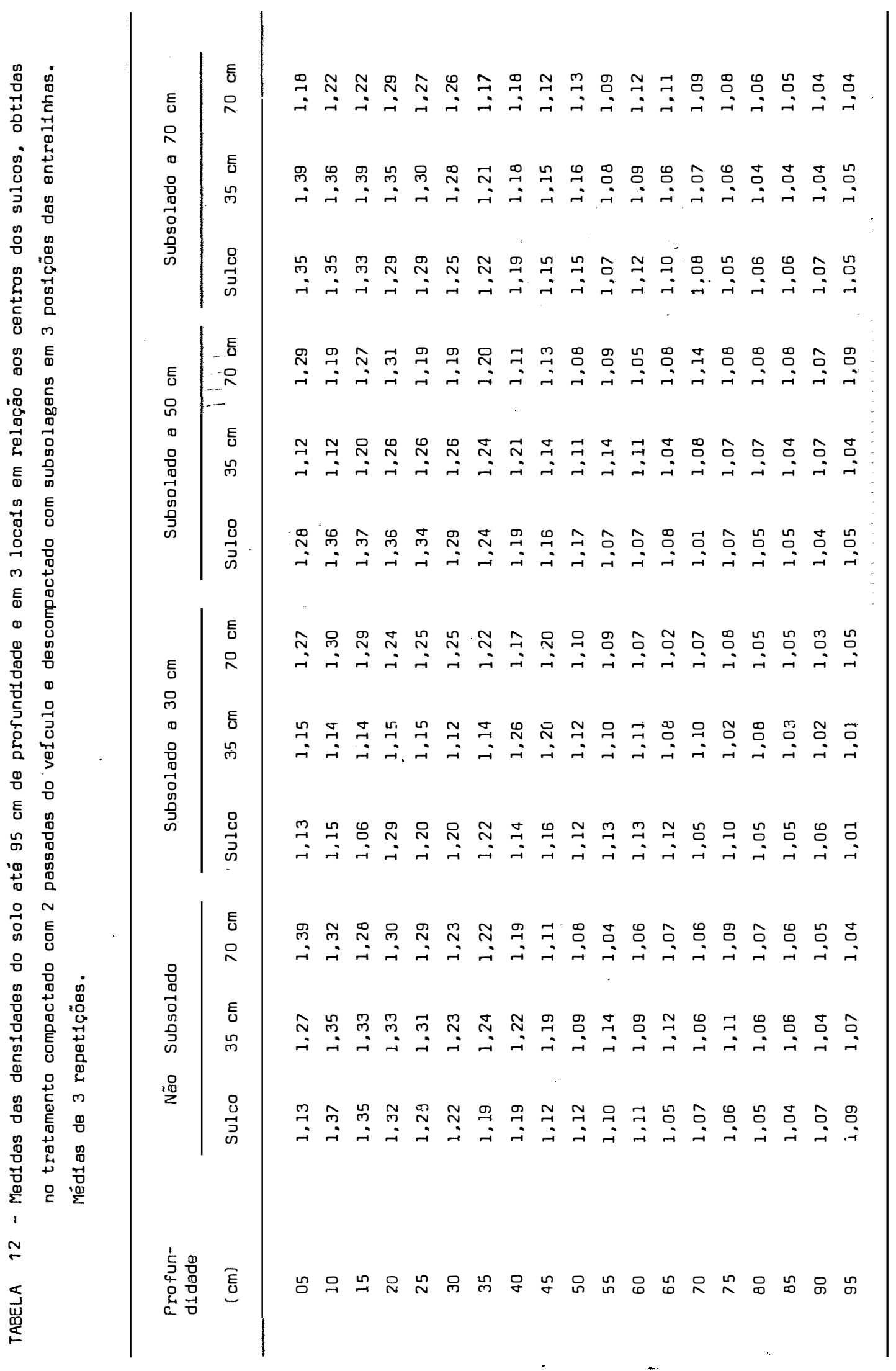




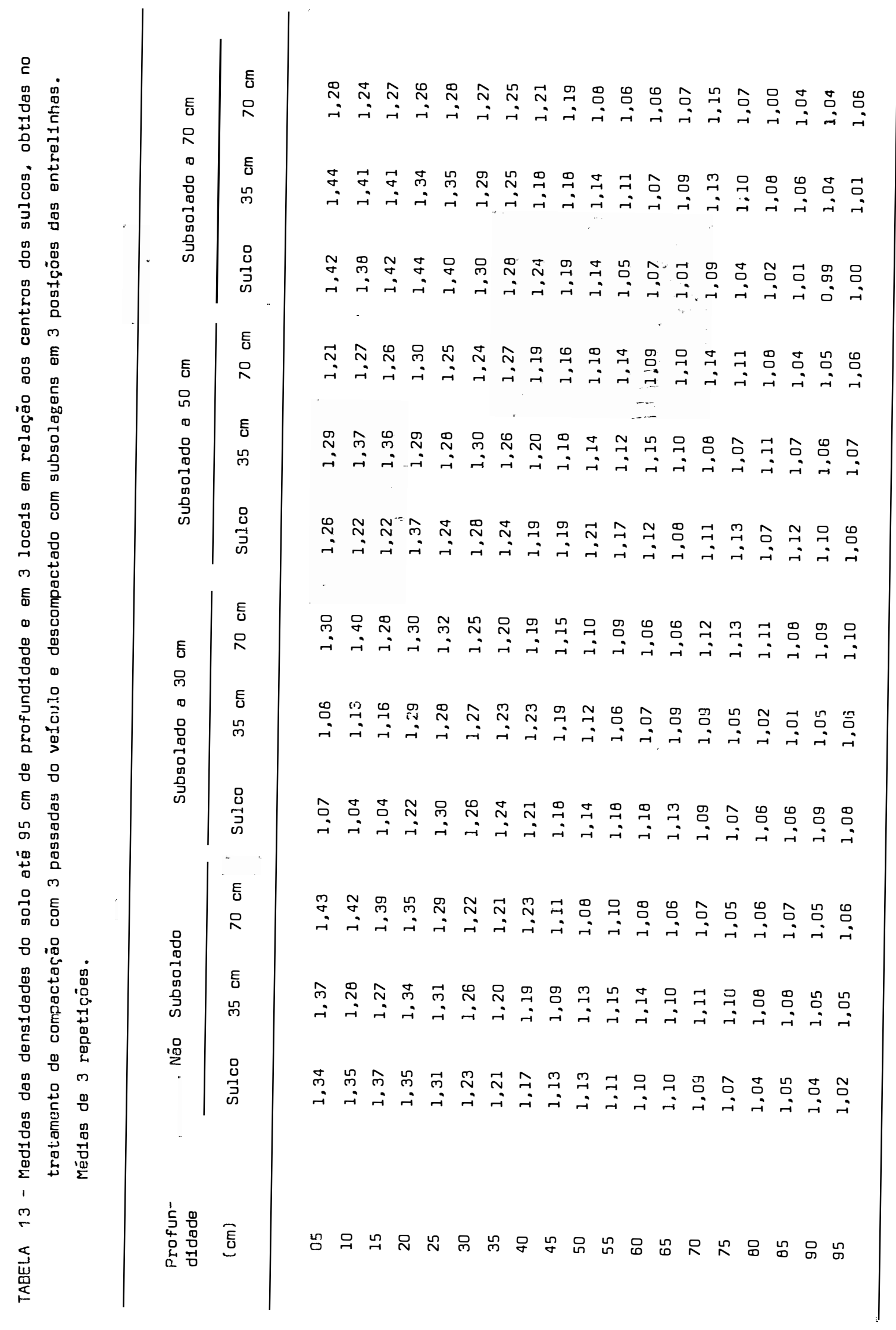




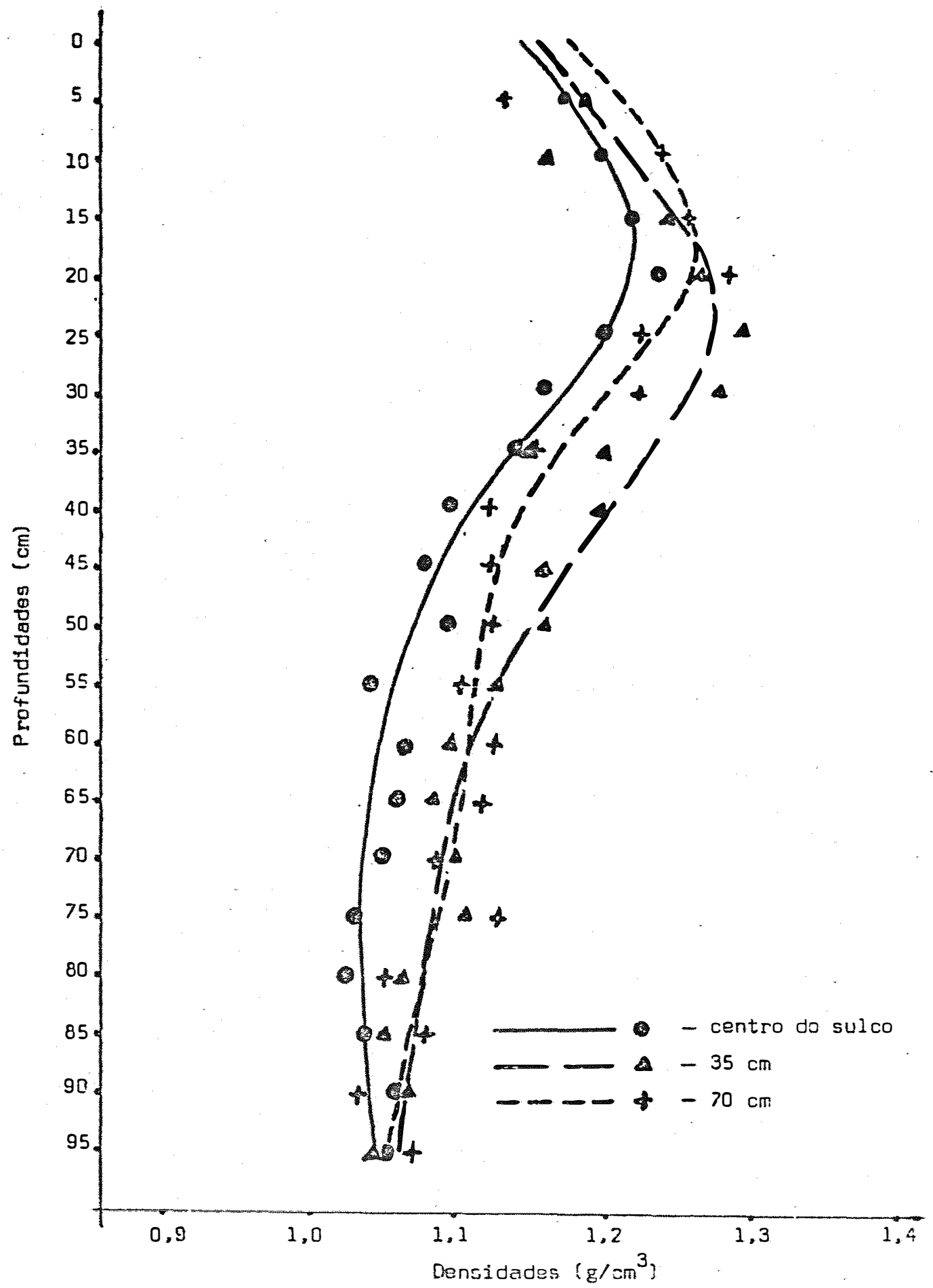

FIG. 10 - Representaçāo das densidades do solo nos 3 perfís até $95 \mathrm{~cm}$ de profundidade, na parcela $n^{8} 25$, nảo compactada e näo subsolada. 


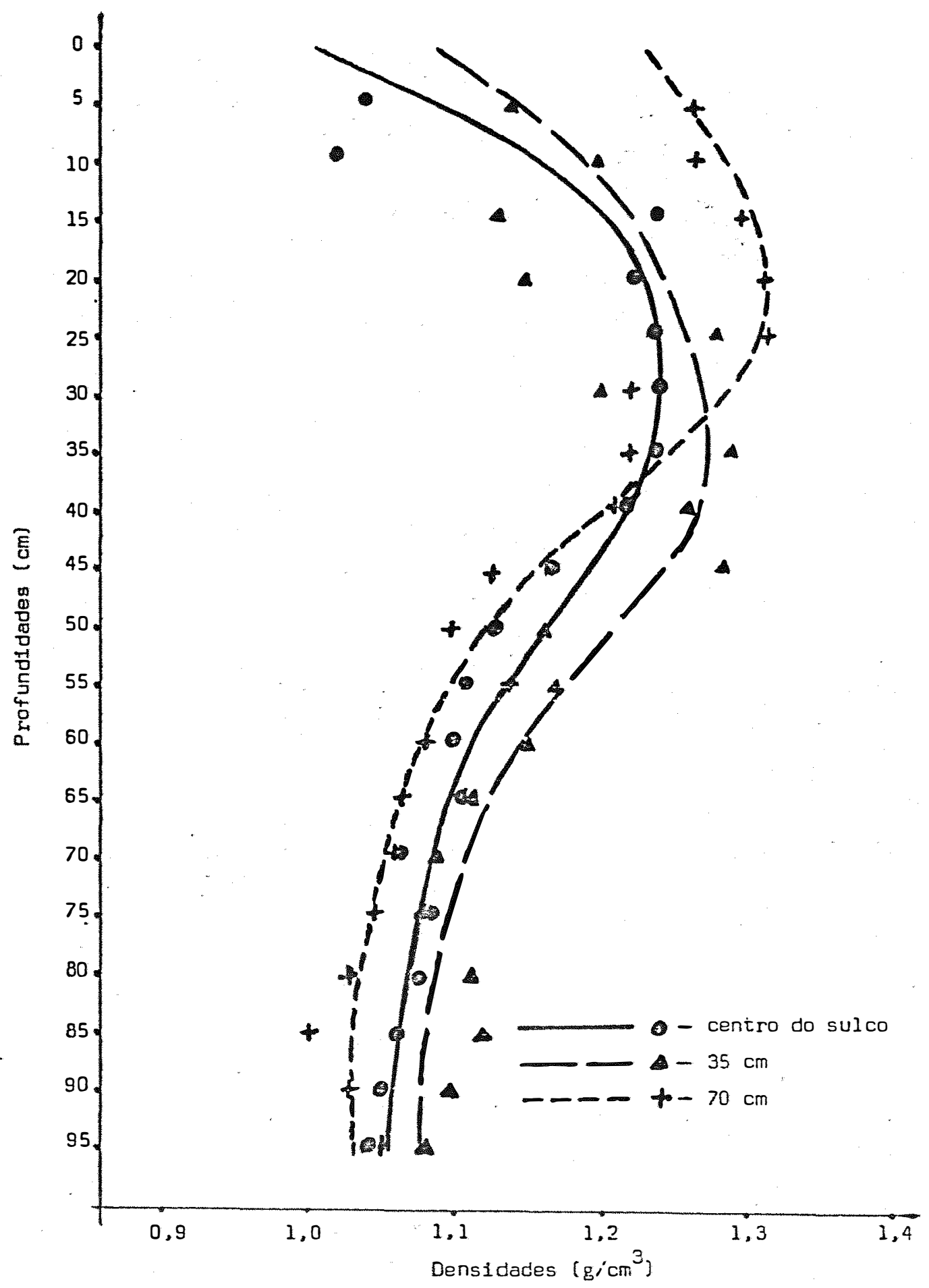

FIG. 11 - Representaçāo das densidades do solo nos 3 perfís até $95 \mathrm{~cm}$ de profundidade, na parcela $n^{8} 17$, náo compactaca e subsolada a $30 \mathrm{~cm}$. 


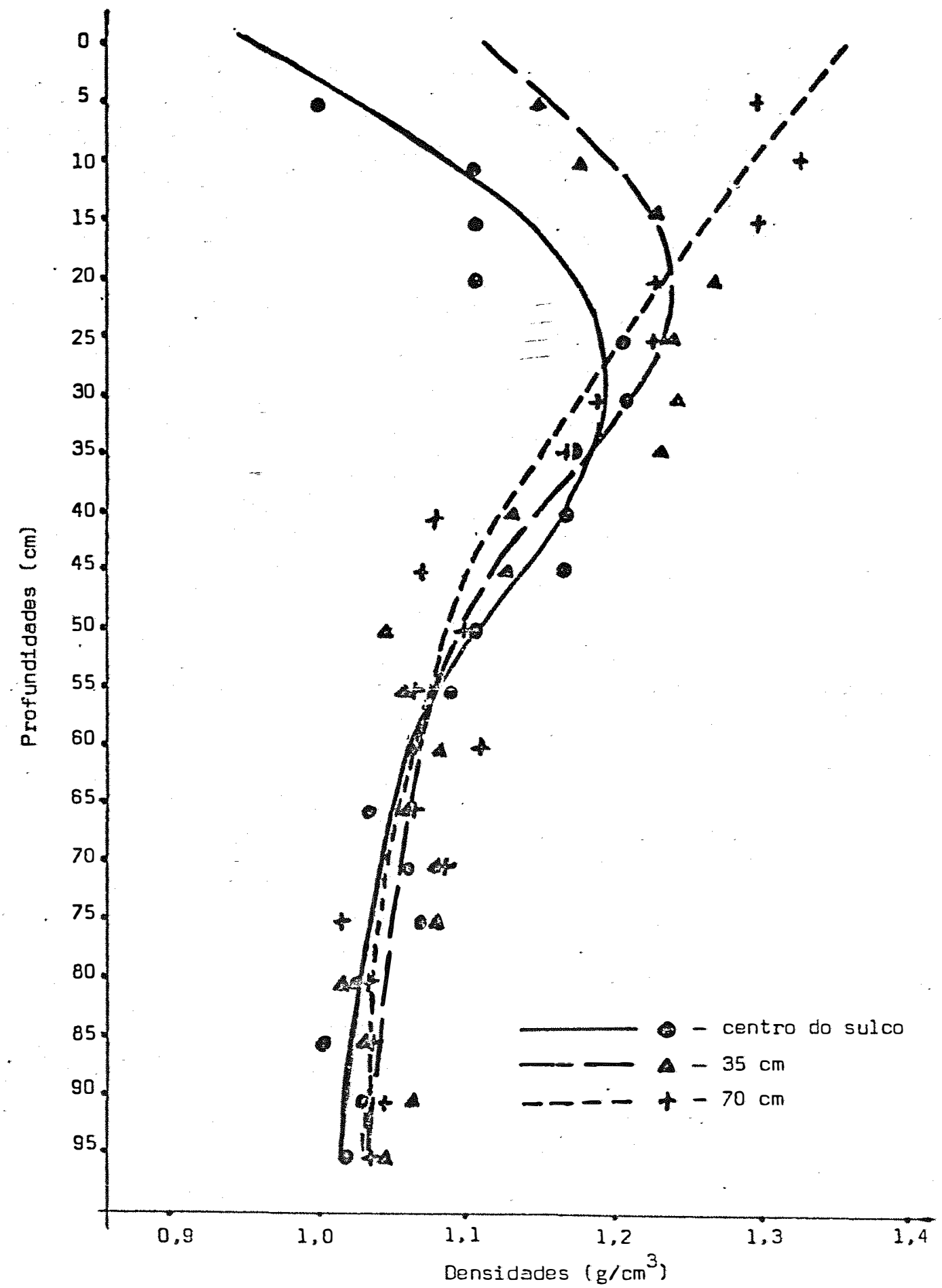

FIG. 12 - Representaçào das densidades do solo nos 3 perfís até $95 \mathrm{~cm}$ de profundidade, na parcela $n^{8} 18$, não compactaja e subsolada a $50 \mathrm{~cm}$. 


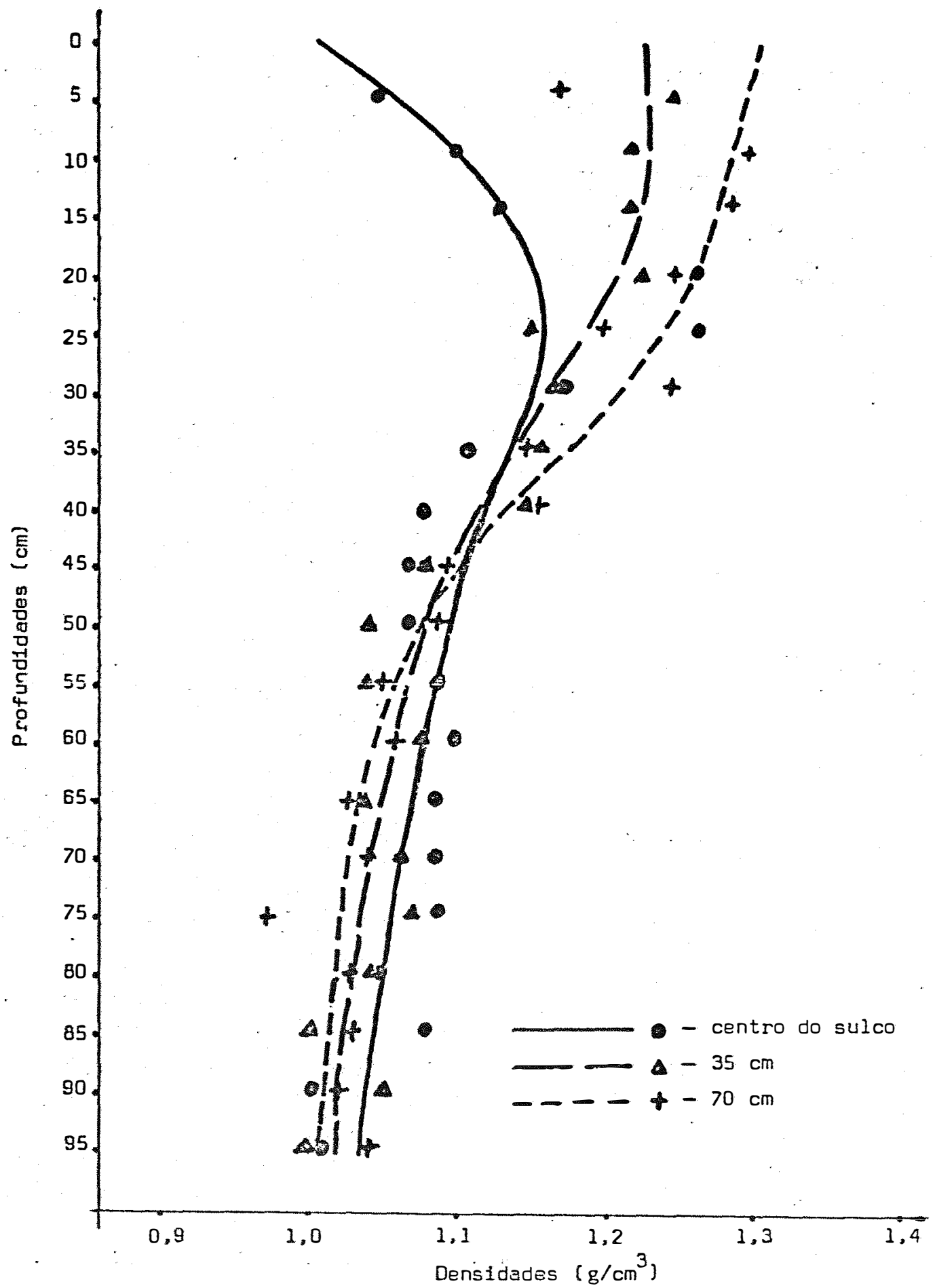

FIG. 13 - Representação das densidades do solo nos 3 perfís até $95 \mathrm{~cm}$ de profundidade, na parcela $n^{8} 26$, não compactada e subsolada a $70 \mathrm{~cm}$. 


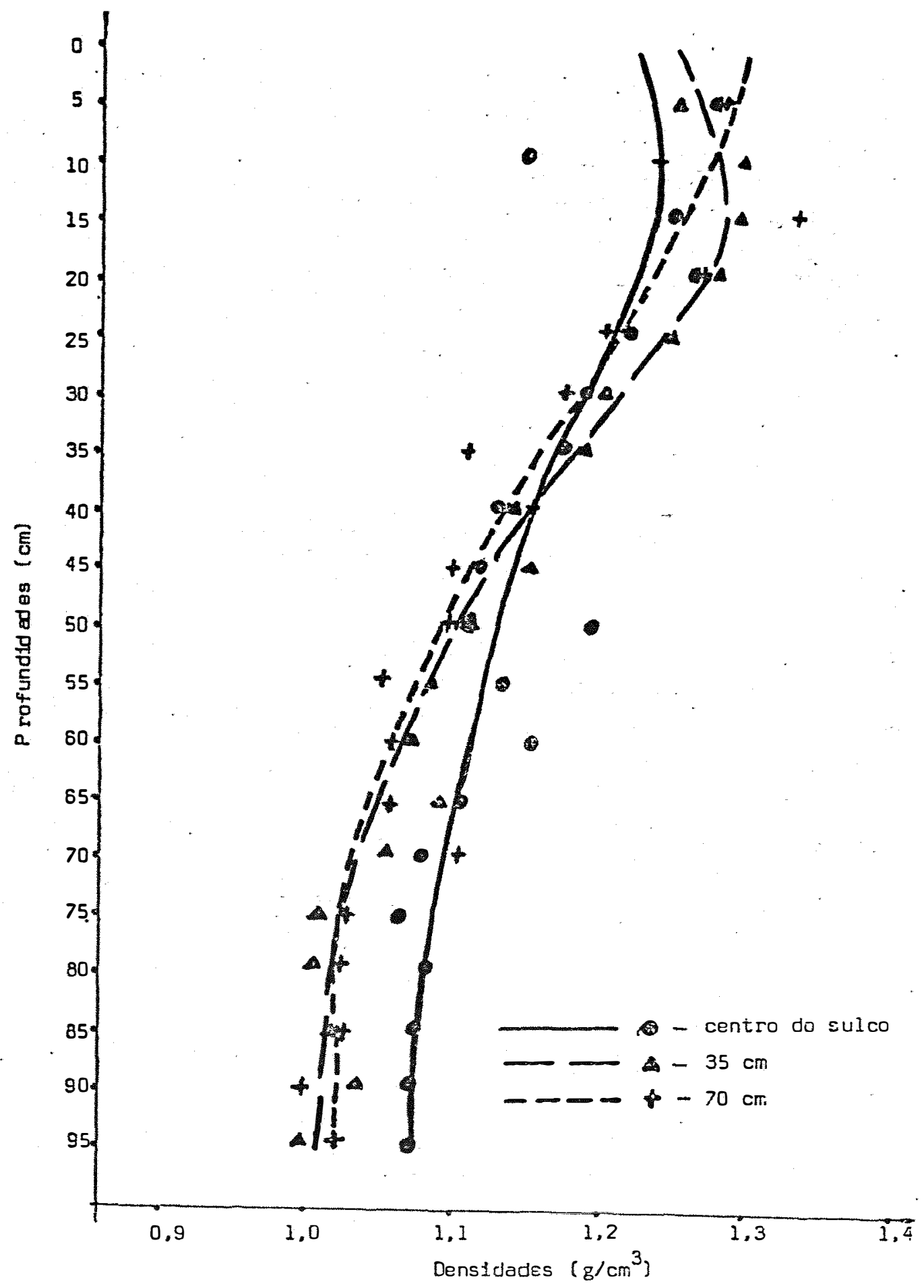

FIG. 14 - Representaçào das densidades do siolo nos 3 perfís até 95 cm de profundidade, na parcela $n^{8} 23$, compactada com 9 passada do veĺculo e nāo subsolada. 


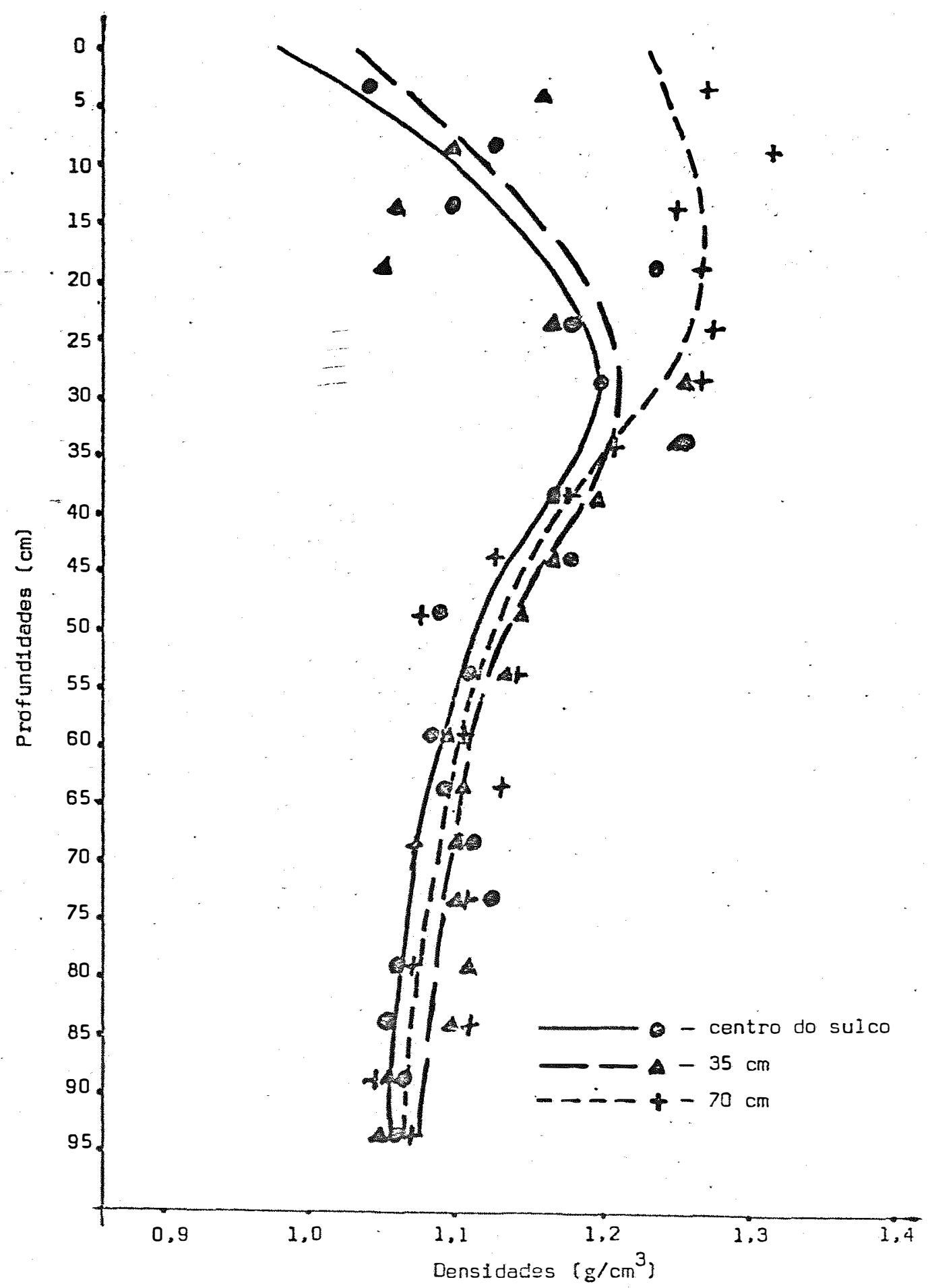

FIG. 15 - Representaçāo das densidades do solo nos 3 perfís atë $95 \mathrm{~cm}$ de profundiciade, na parcela $n^{9} 31$, compactada com 1 passada do velculo e subsolaca a $30 \mathrm{~cm}$. 


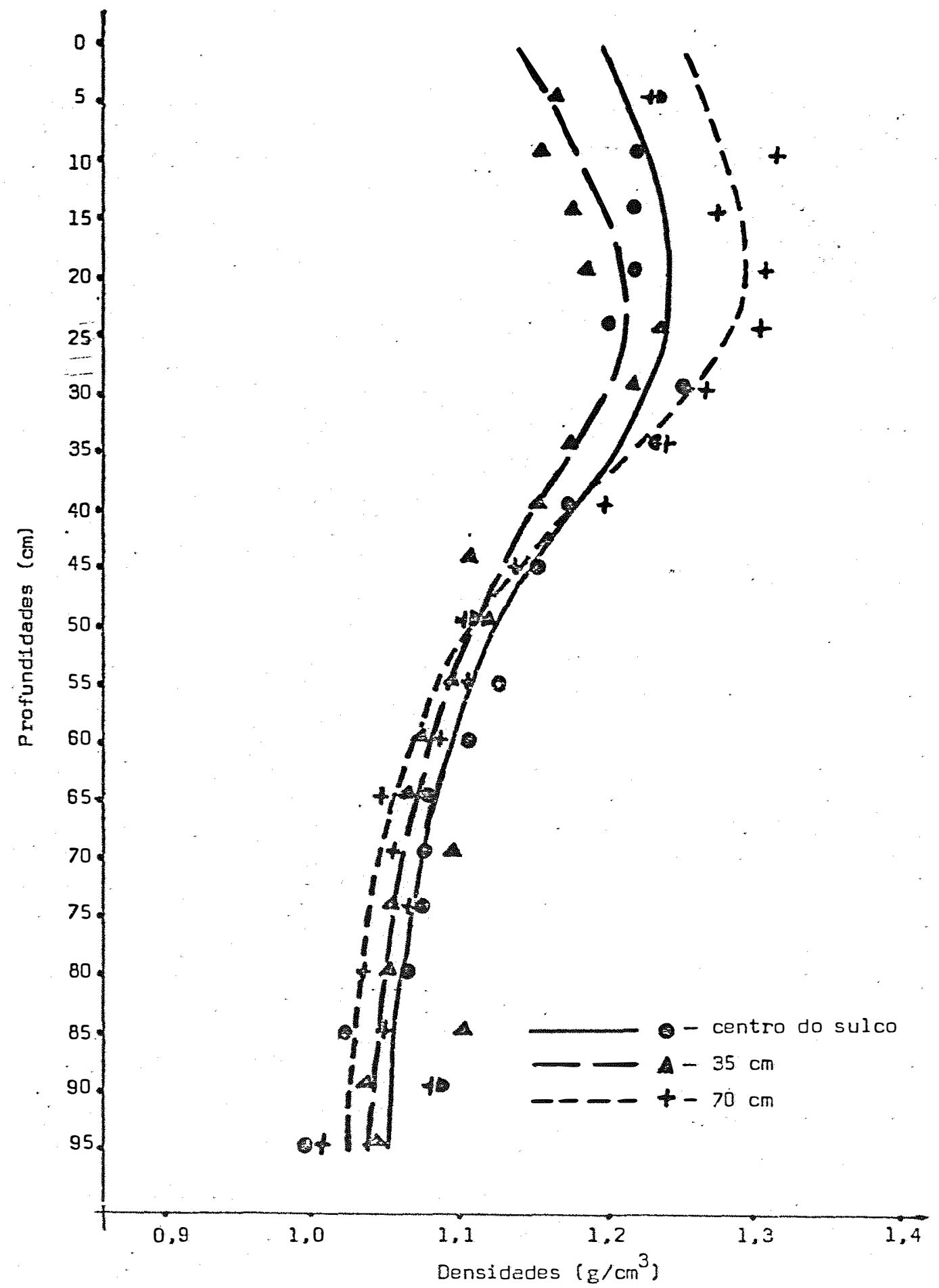

FIG. 16 - Representação das densidades do solo nos 3 perfís até $95 \mathrm{~cm}$ de profundidade, na parcela $n^{8} 32$, compactada com 1 passada do veículo e subsolada a $50 \mathrm{~cm}$. 


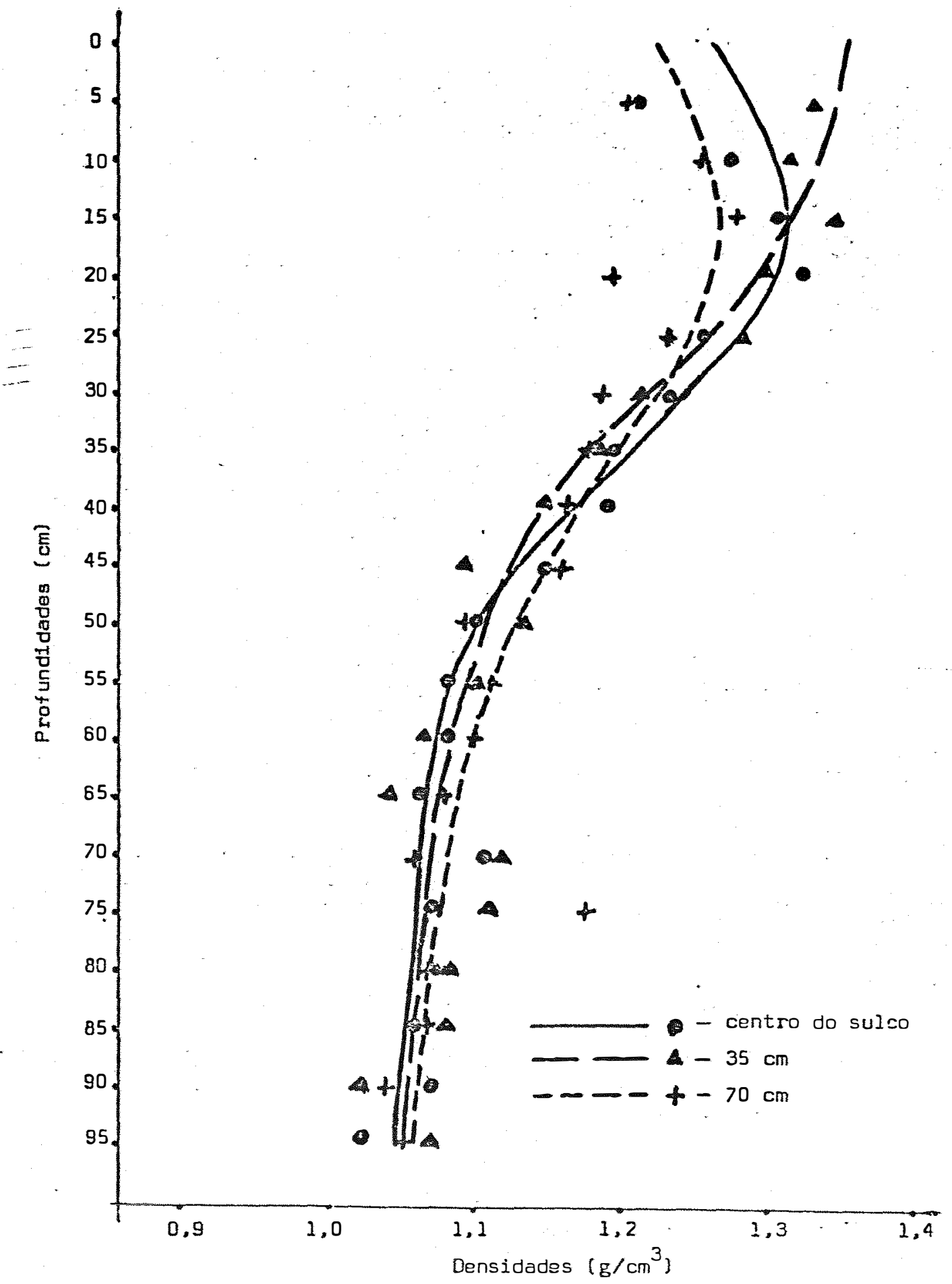

FIG. 17 - Representaçào das densidades do solo nos 3 perfís atẽ $95 \mathrm{~cm}$ de profundidade, na parcela $n^{9} 24$. compactada com 1 passada do veículo e subsolada a $70 \mathrm{~cm}$. 


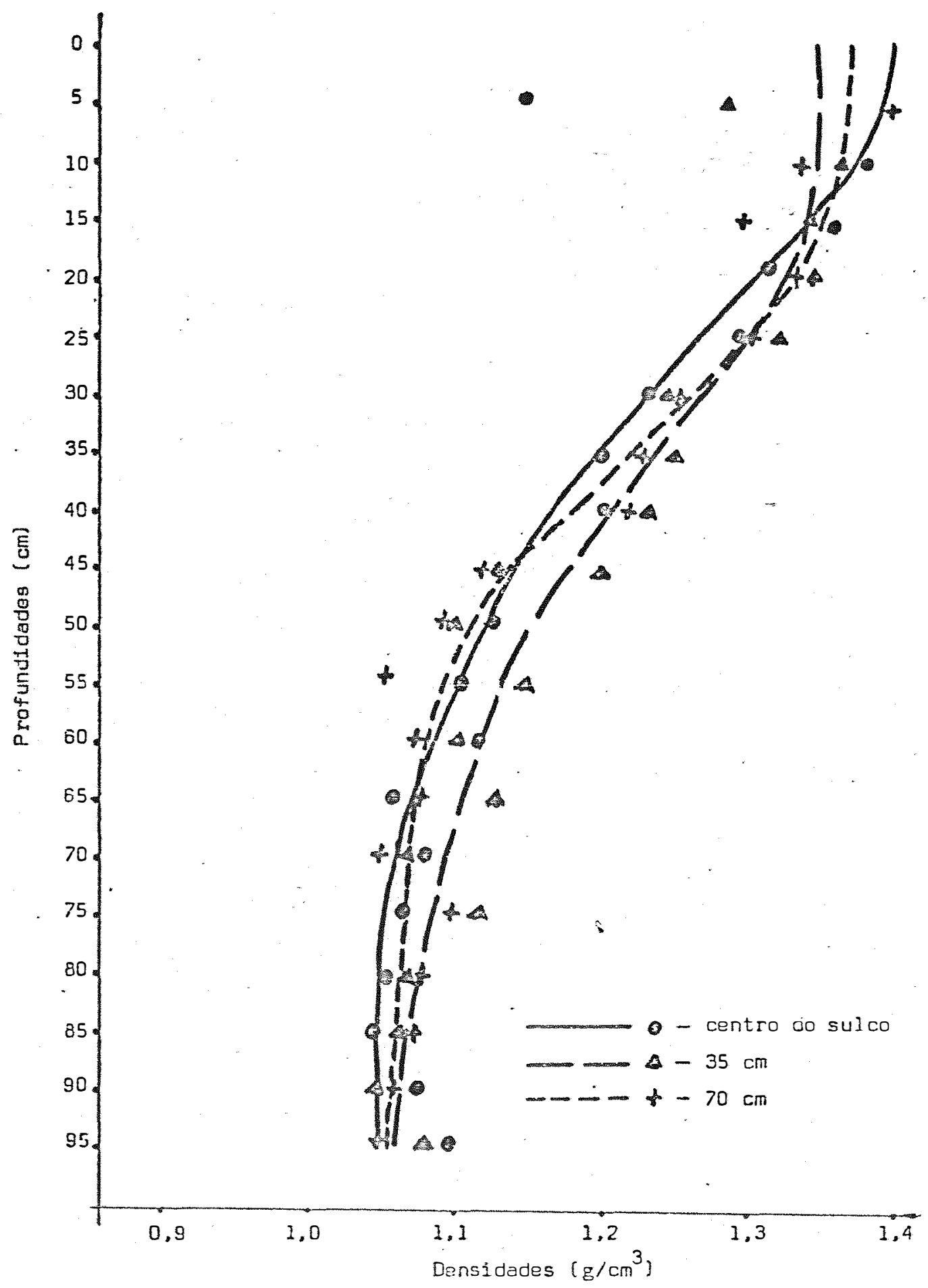

FIG. 18 - Representaçào das densidades do solo nos 3 perfís até $95 \mathrm{~cm}$ de profundidacje, na parcela $n^{8} 21$, compactada com 2 passadas do velculo e não subsolaja. 


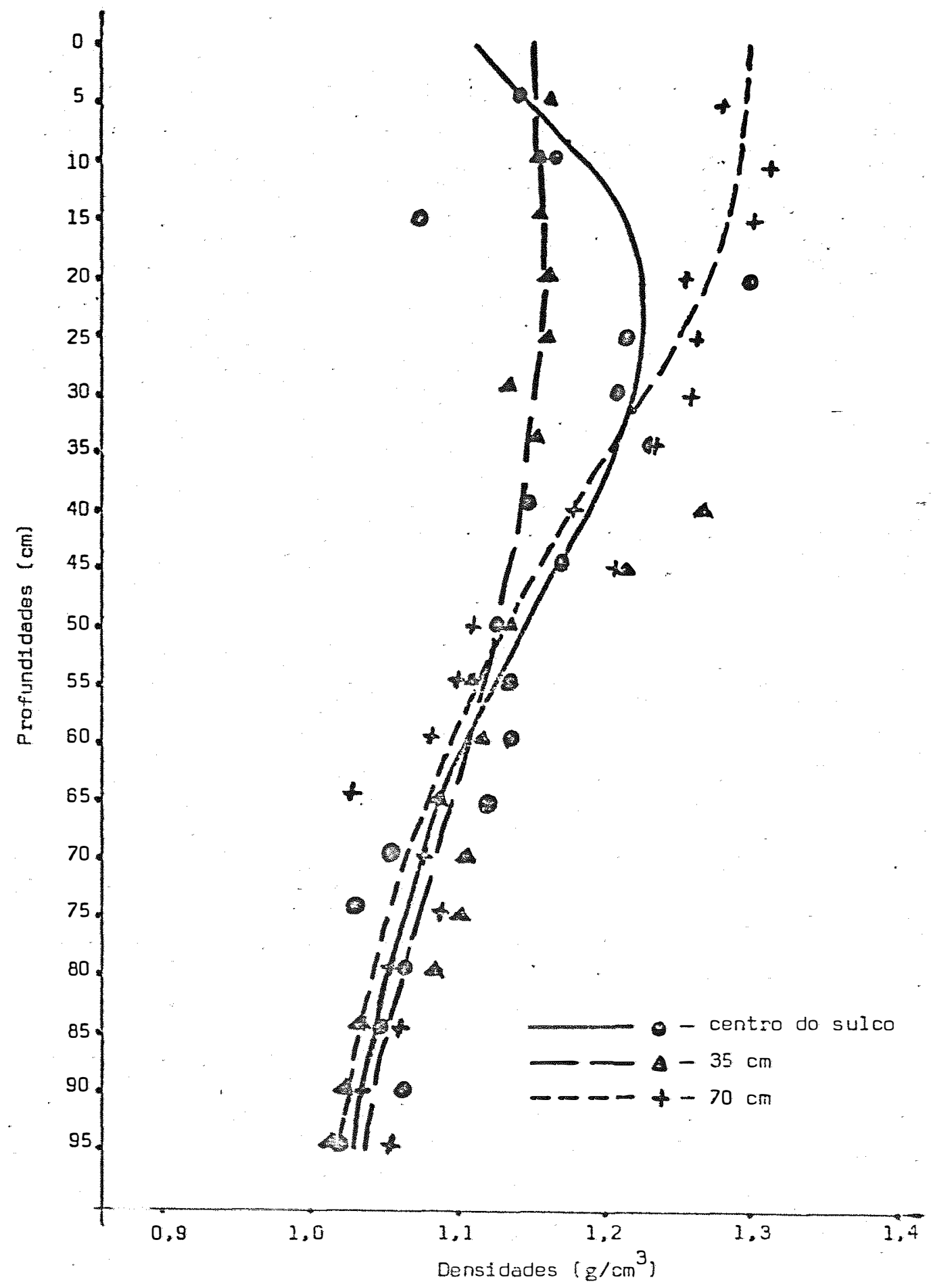

FIG. 19-Representaçāo das densidades do 5010 nos 3 perfis ate $95 \mathrm{~cm}$ de profundidade, na parcela $n^{8} 29$, compactada com 2 passadas do veículo e subsolada a $30 \mathrm{~cm}$. 


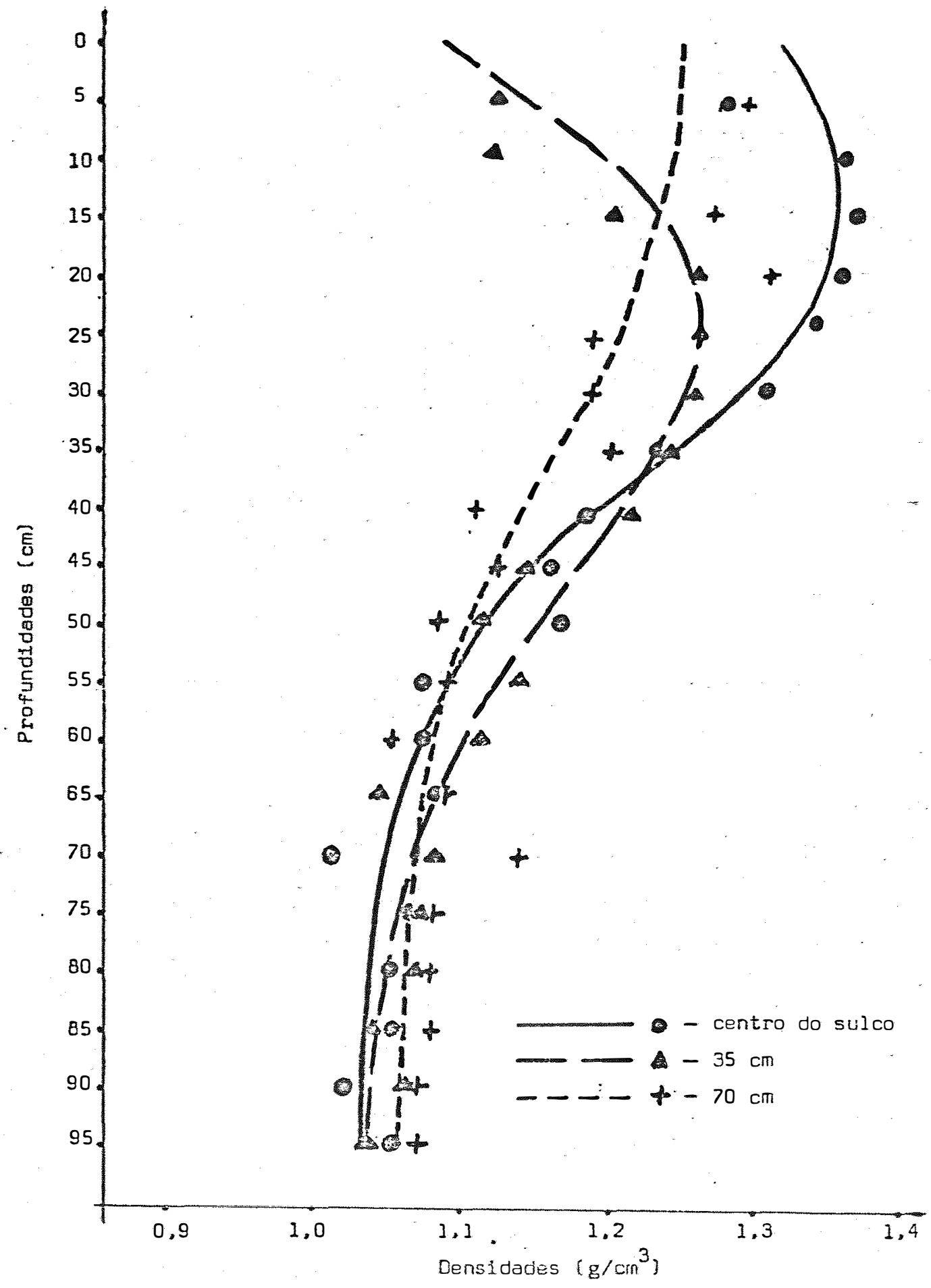

FIG. 20-Representaçāo das densidades do solo nos 3 perfís até $95 \mathrm{~cm}$ de profundidace, na parcela $n^{2} 22$, compactada com 2 passadas do veĺculo e subsolada $ə 50 \mathrm{~cm}$. 


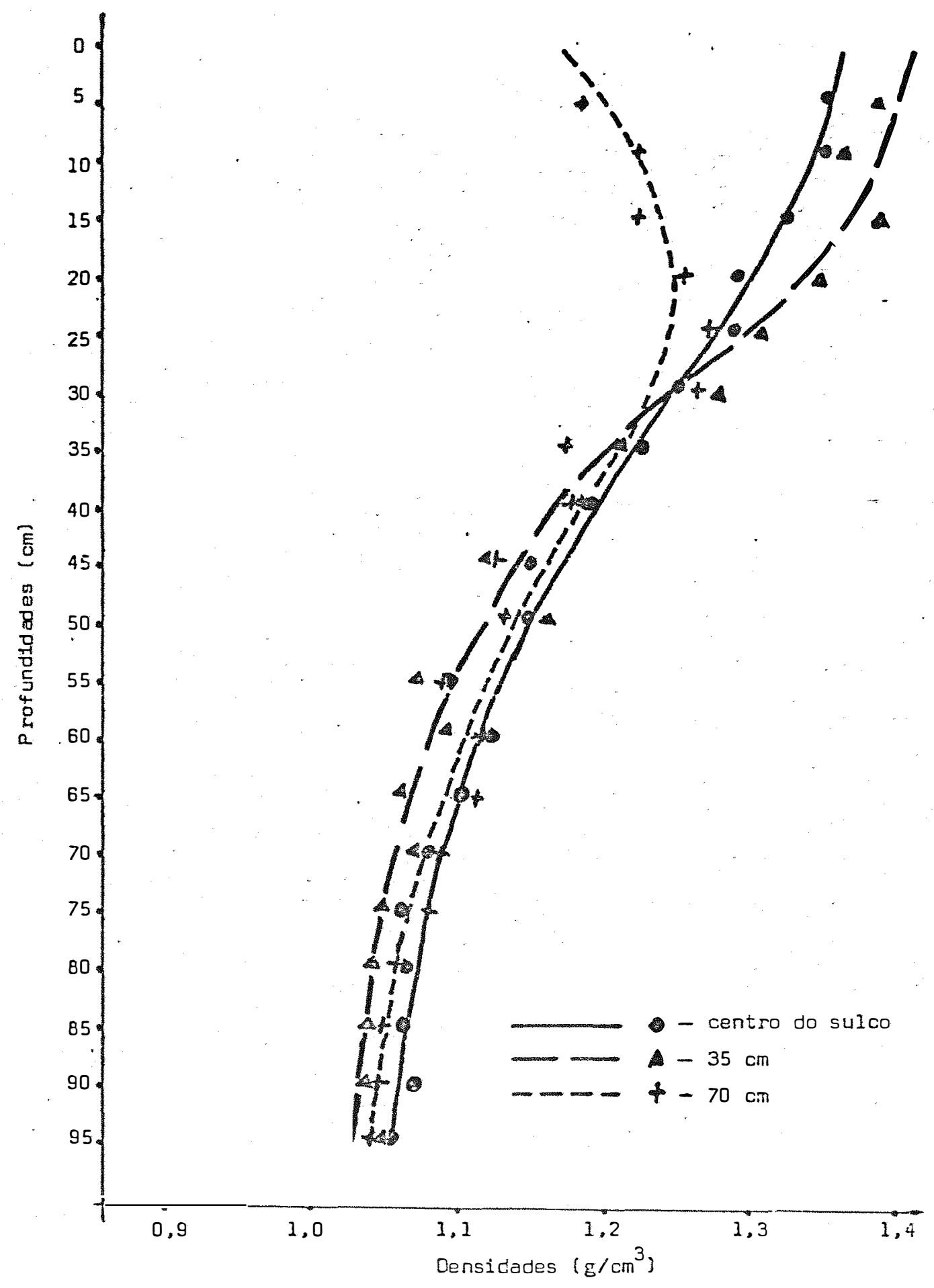

FIG. 21 - Representação des densidades do solo nos 3 perfís até $95 \mathrm{~cm}$ de profundidade, na parcela $n^{8} 30$, compectada $\operatorname{com} 2$ passadas do veículo e subsolada a $70 \mathrm{~cm}$. 


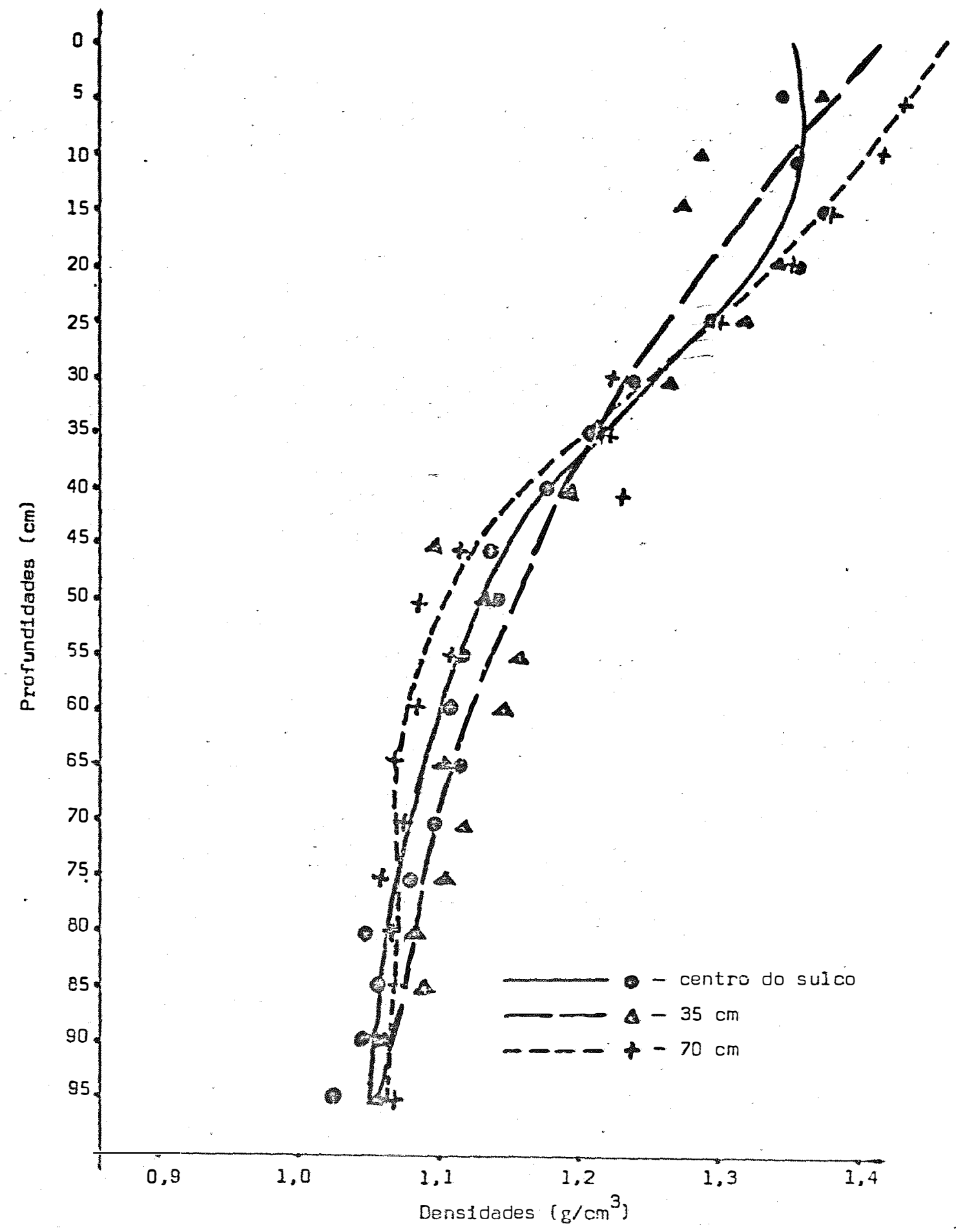

FIG. "22-Representaçäo das denisidades do solo nos 3 perfís atë $95 \mathrm{~cm}$ de profundidude, na parcela $n^{\circ} 27$, compactada com 3 passadas do veículo e nāo subsolada. 


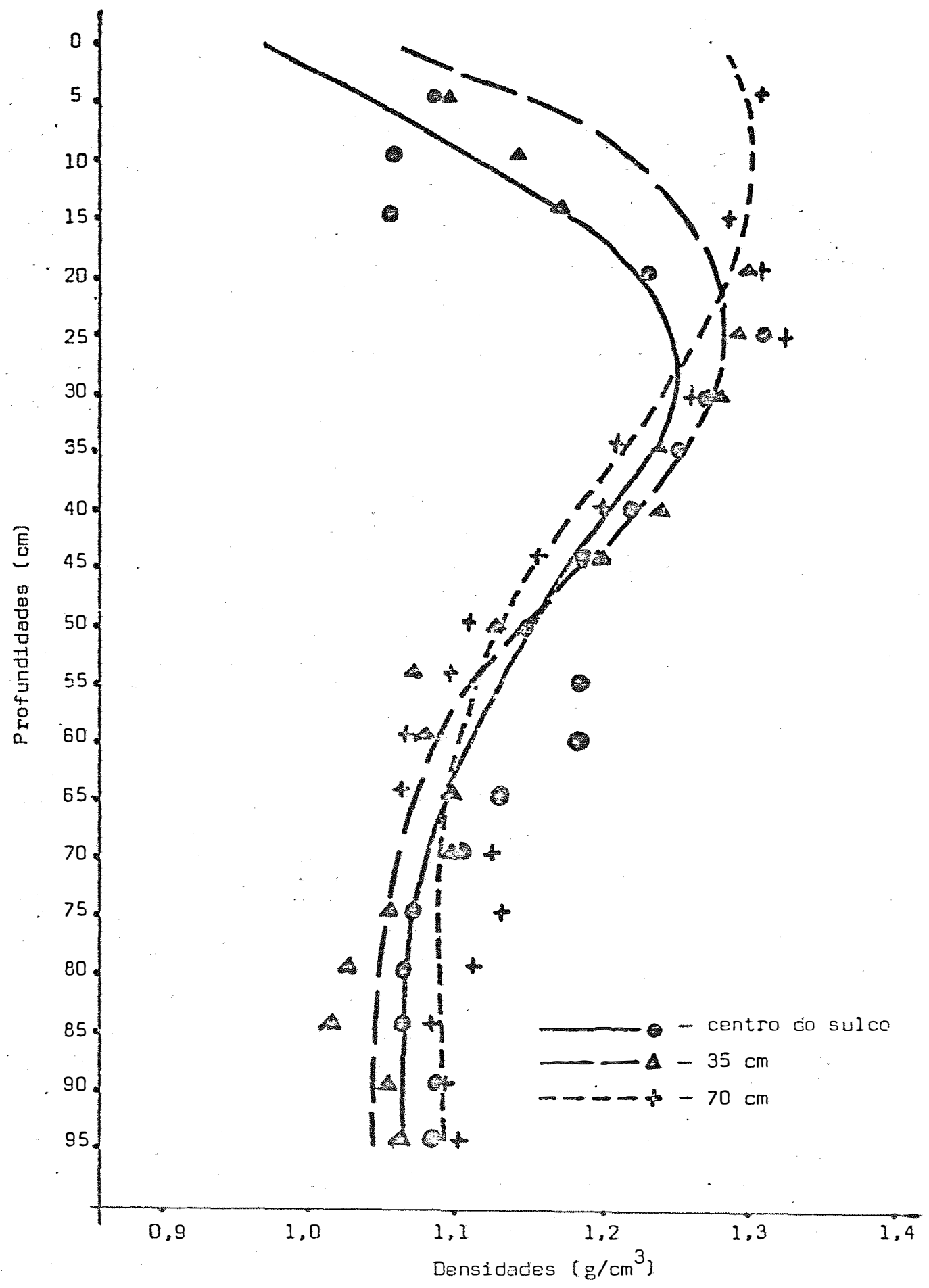

FIG. 23 - Representaçāo das densidades do solo nos 3 perfís até $95 \mathrm{~cm}$ de profundidade, na parcela $n^{8} 19$. compactada com 3 passadas cio veĺculo e subsoladia a $30 \mathrm{~cm}$. 


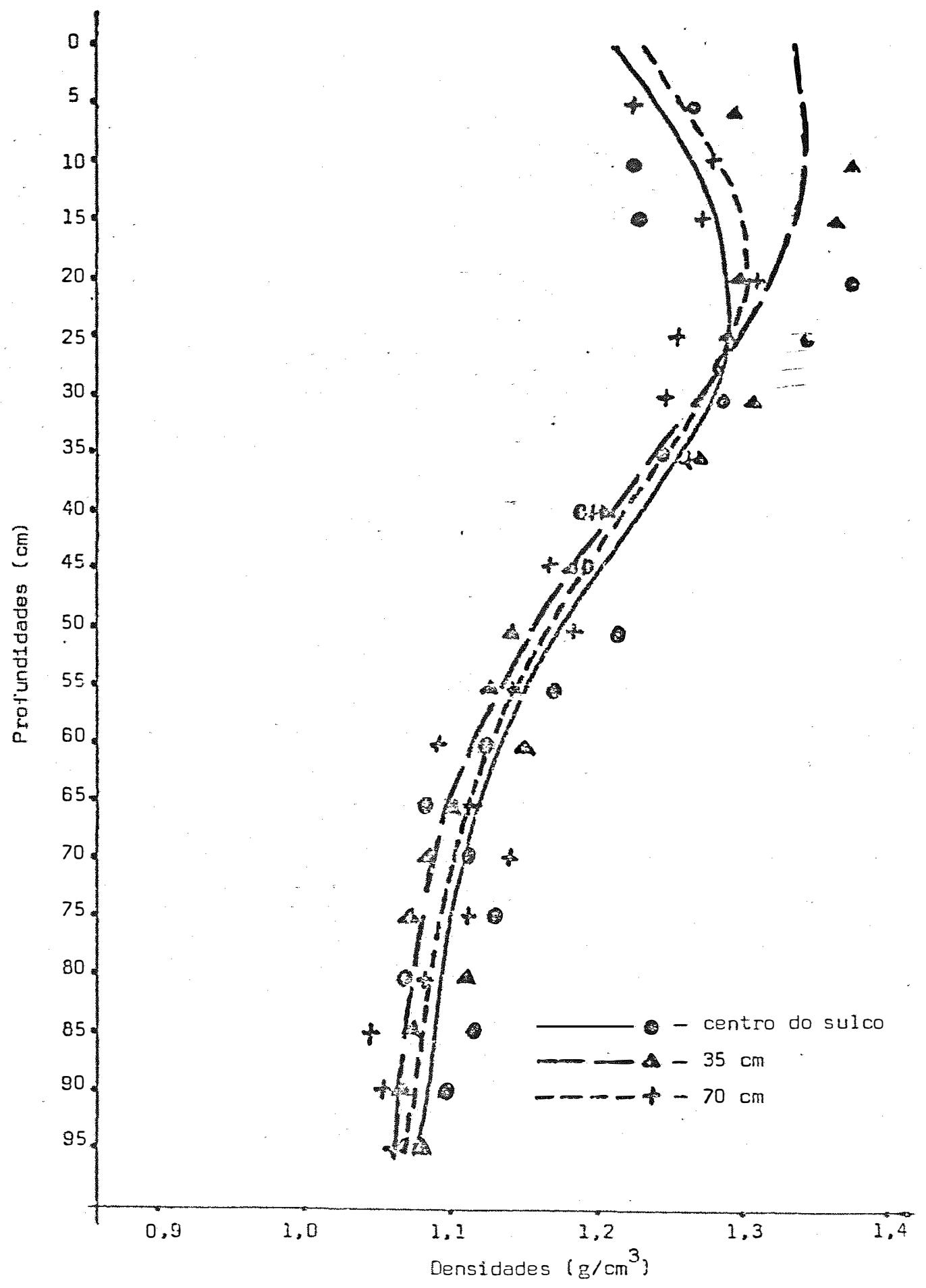

FIG. 24-Represcntaçāo das densidades do solo nos 3 perfís até $95 \mathrm{~cm}$ de profundidade, na parceìa $n^{8} 20$, compactada cum 3 passadas do vé́culo e suosolada a $50^{\circ} \mathrm{cm}$. 


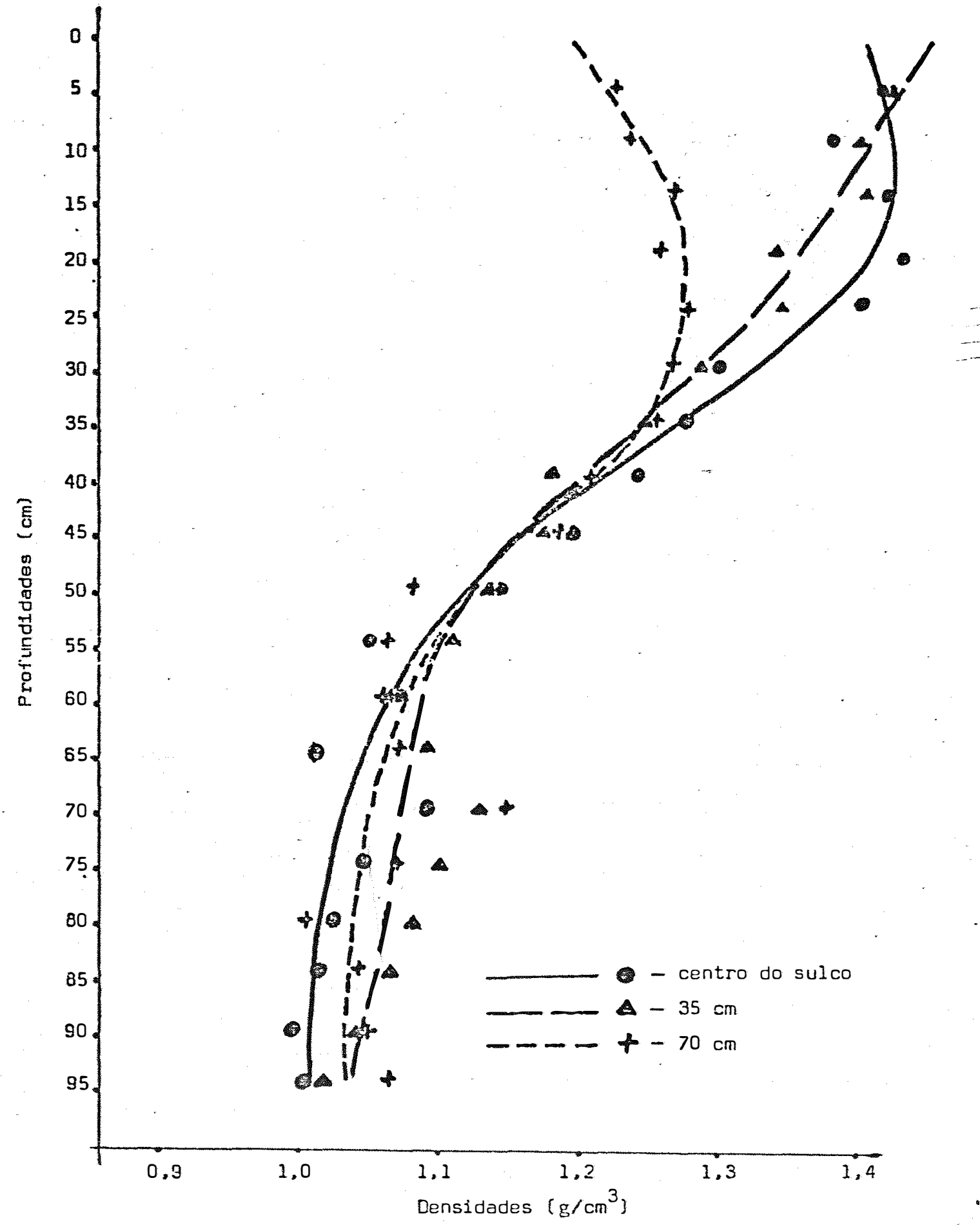

FIG. 25 - Representação das densidades do solo nos 3 perfís até $95 \mathrm{~cm}$ de profundidade, na parcela $n^{\circ} 28$, compactada com 3 passadas do veśculo e subsolada a $70 \mathrm{~cm}$. 
baixou os índices de densidade na área da projeção da linha de cana e a 35 cm do centro do sulco; quando a subsolagem foi feita a $50 \mathrm{~cm}$, a menor densidade do solo verificou-se na amos tragem a $35 \mathrm{~cm}$; enquanto que, na subsolagem realizada no cen tro da entrelinha, essa ärea mostrou-se menos compactada que a própria faixa com cana.

A partir de $25 \mathrm{~cm}$ de profundidade as linhas re presentativas das densidades seguiram paralelamente através dos perfís.

Os tratamentos com 2 passadas do veículo mostraram marcantes efeitos de compactação do soío. A parcela compactada e que não recebeu subsolagem (figuráa 18), teve seus índices de densidade elevados para valores até 1;39 na entrelinha, acompanhados de perto pelas densidades no centro do sulco e nas laterais da faixa de soqueiras. A condição de compactação acima de 1,20 permaneceu até à profundidade de $40-45 \mathrm{~cm}$.

A subsolagem a $30 \mathrm{~cm}$ do centro do sulco $(20 \mathrm{~cm}$ ao lado da linha de canal mostra ter exercido eficaz benefício à faixa ocupada pela linha contendo a cana (35 cm cada lado, a partir do centro do sulcol. Mas a subsolagem a $50 \mathrm{~cm}$ não conseguiu o mesmo efeito, mostrando sua atividade em favor da entrelinha, enquanto que a estreita faixa na projeção da linha de caria, apresentou os mais altos índices de compac tação com densidades próximas de 1,30 até a profundidade de $30 \mathrm{~cm}$.

Quanto à subsolagem a $70 \mathrm{~cm}$, conforme mostra a figura 21, revela seus efeitos somente na entrelinha, onde os índices de densidade baixaram para valores ao redor de 1,20 até a profundidade de $20 \mathrm{~cm}$, atingindo o ponto máximo de 1,26 aos $30 \mathrm{~cm}$. Enquanto isso, a faixa de solo contendo a linha de cana, permaneceu com os mais altos níveis de compactação, cujas densidades próximas de l,40 na superfície, baixaram lentamente nos perfís inferiores, para alcançarem 1,20 somen te aos $35 \mathrm{~cm}$ de profundidade.

As compactações com 3 passadas do veículo estão 
representadas nas figuras 22 a 25 .

O tratamento testemunha não subsolado da figura 22, mostra um comportamento semelhante ao mesmo tratamento com 2 passadas da figura 18. Apenas difere quanto ao efei to acumulado, elevando as densidades das camadas mais superficiais, de 1,32 a 1,38 para $1,35 \cdots$ a 1,40 como termos médios. As reduções nos valores das densidades através dos perfís do solo foram equivalentes, alcançando 1,10 a $50-55 \mathrm{~cm}$ de pro fundidade.

0 tratamento subsolado a $30 \mathrm{~cm}$ do centro do sul co, favoreceu visivelmente os 2 planos -internos amostrados (centro do sulco e $35 \mathrm{~cm}$ ) porém, somente nos 15 cm superficiais porque, a partir daí, as densidades voltaram a aproxi mar-se de $1,30 \mathrm{~m}$. O pōnto de máxima compactação permaneceu entre 25-30 cm de profundidade, reduzindo-se essesvalores pa ra 1,10 aos $50 \mathrm{~cm}$ abaixo da superfície.

Quanto ao tratamento com subsolagem a $50 \mathrm{~cm}$ do centro do sulco, mostra efeitos pouco significativos apenas nos 10-15 cm superficiais do solo. Entre 25 e 35 cm as densidades permaneceram com valores médios ao redor de 1,30.

A subsolagem no centro da entrelinha mostrou coerência quanto à descompactação nesse plano, mas em nada contribuiu como subsolagem nos planos mais próximos da linha, onde as densidades mantiveram os valores médios de 1,40 como no tratamento não subsolado.

5.4. Efeitos na produção de cana

5.4.1. População de colmos

O número de colmos por metro linear de sulco é mostrado na tabela 14 .

Foi feita a análise de variáncia cujos resulta dos estão na tabela 15 . 
TABELA 14 - Número de colmos por metro linear de sulco.

\begin{tabular}{|c|c|c|c|c|c|c|}
\hline \multirow{2}{*}{ Passos } & \multirow{2}{*}{ Trat. } & \multicolumn{3}{|c|}{ Repetições } & \multirow{2}{*}{ Soma } & \multirow{2}{*}{ Média } \\
\hline & & I & II & III & & \\
\hline \multirow{5}{*}{0} & & & & & - & \\
\hline & 0 & 10,03 & 10,01 & 10,02 & 30,06 & 10,02 \\
\hline & 30 & 10,88 & 10,13 & 10,17 & 31,18 & 10,39 \\
\hline & 50 & 9,51 & 10,07 & 9,89 & 29,47 & 9,82 \\
\hline & 70 & 10,78 & 10,27 & 10,90 & 31,95 & 10,65 \\
\hline \multirow{5}{*}{1} & & - & & & & \\
\hline & 0 & 11,61 & 10,87 & 12,09 & 34,57 & 11,52 \\
\hline & 30 & 12,34 & 13,20 & 12,40 & 37,94 & 12,65 \\
\hline & 50 & 11,09 & 11,25 & 10,99 & 33,33 & 11,11 \\
\hline & 70 & 10,78 & 11,78 & 11,96 & 34,52 & 11,51 \\
\hline \multirow{4}{*}{2} & 0 & 10,95 & 10,32 & 12,29 & 33,56 & 11,19 \\
\hline & 30 & 11,87 & 12,71 & 12,44 & 37,02 & 12,34 \\
\hline & 50 & 10,97 & 11,17 & 10,75 & 32,89 & 10,96 \\
\hline & 70 & 11,27 & 10,95 & 11,27 & 33,49 & 11,16 \\
\hline \multirow{4}{*}{3} & 0 & 12,33 & 12,59 & 13,42 & 38,34 & 12,78 \\
\hline & 30 & 12,62 & 12,05 & 12,81 & 37,48 & 12,49 \\
\hline & 50 & 13,33 & 13,12 & 11,62 & 38,07 & 12,69 \\
\hline & 70 & 11,78 & 11,40 & 11,64 & 34,82 & 11,61 \\
\hline
\end{tabular}




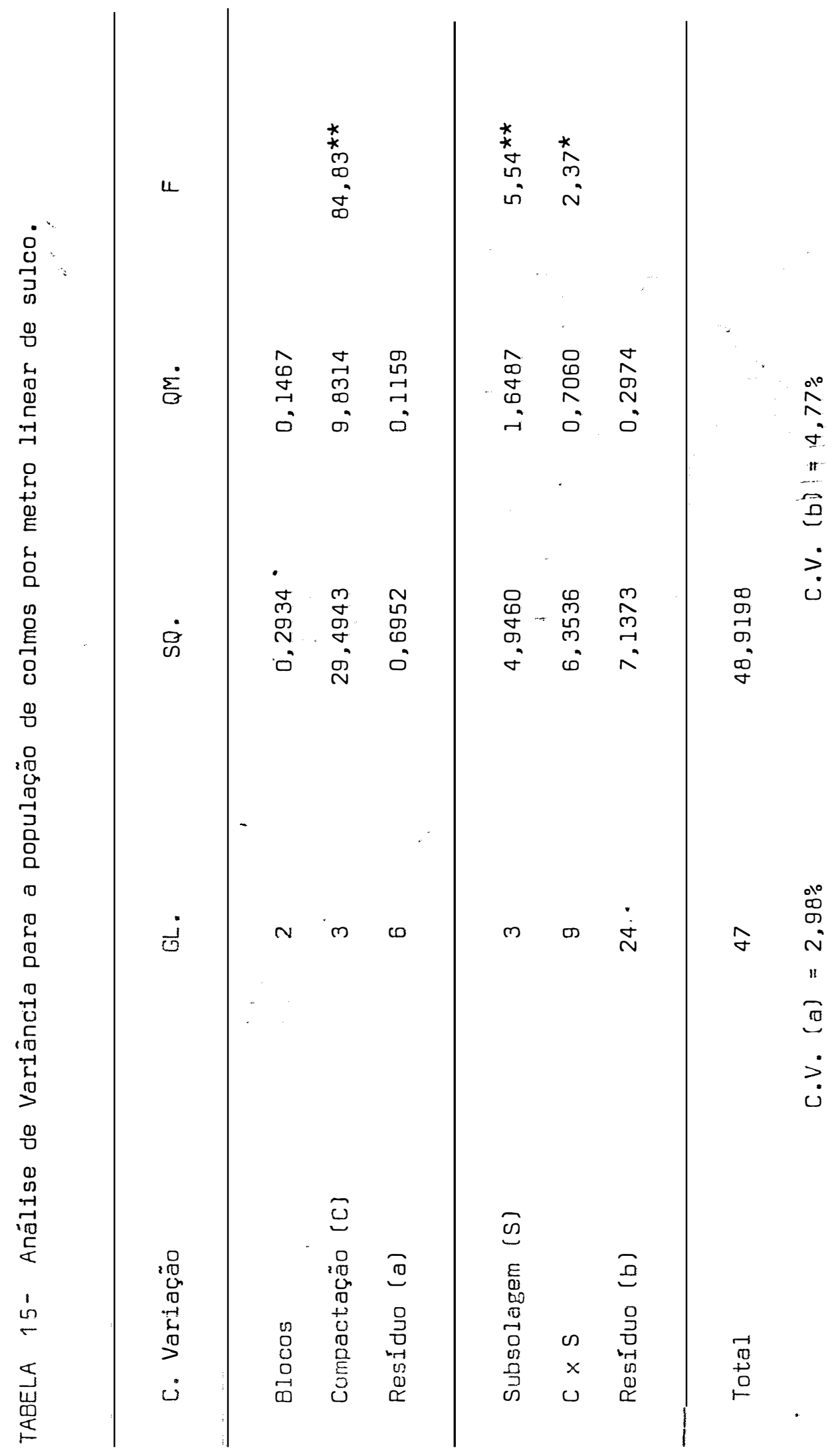


Observa-se que houve efeito significativo ao

nível de $1 \%$ de probabilidade tanto para Compactação como pa ra Subsolagem, assim como de $5 \%$ para a interação entre ambos.

Através do desdobramento da interação entre as 2 modalidades operacionais, conforme revela a tabela 16, cons tatou-se que, somente os tratamentos de compactação com 1 e 2 passadas, apresentaram efeitos significativos, ao nível de $5 \%$ de probabilidade.

Quanto às operações de subsolagem, incluidos os tratamentos de compactação, observa-se que apenas o trabalho realizado a 70 cm (centro da entrelinfa de cana) não apresentou significāncia. Entretanto, os tratamentos de sub solagem a $30 \mathrm{~cm}$ e a $50 \mathrm{~cm}$, juntamente com a testemunha não subsolada, mostraram significāncia estatística ao nível de $1 \%$.

Observando-se os quadros seguintes, com os resultados das médias para ambos os tratamentos, verifica-se que a população de colmos no sulco aumentou no sentido da testemunha, não compactada, para as compactações com 1 , 2 e 3 pas sadas do veículo. Por outro lado, os tratamentos de subsola gem não apresentaram variações expressivas.

\begin{tabular}{|c|c|c|c|c|c|}
\hline & \multicolumn{2}{|c|}{ Compactação } & \multicolumn{3}{|c|}{ Subsol agem } \\
\hline & $T$ & 10,22 & & 0 & 11,38 \\
\hline & 1 & 11,70 & & 30 & 11,97 \\
\hline & 2 & 11,41 & & 50 & 11,15 \\
\hline & 3 & 12,39 & & 70 & 11,23 \\
\hline$s(\bar{m})$ & & 0,10 & $s(\bar{m})$ & & 0,16 \\
\hline$d \cdot m \cdot s$. & & 0,48 & $d \cdot m \cdot s$. & & 0,61 \\
\hline
\end{tabular}




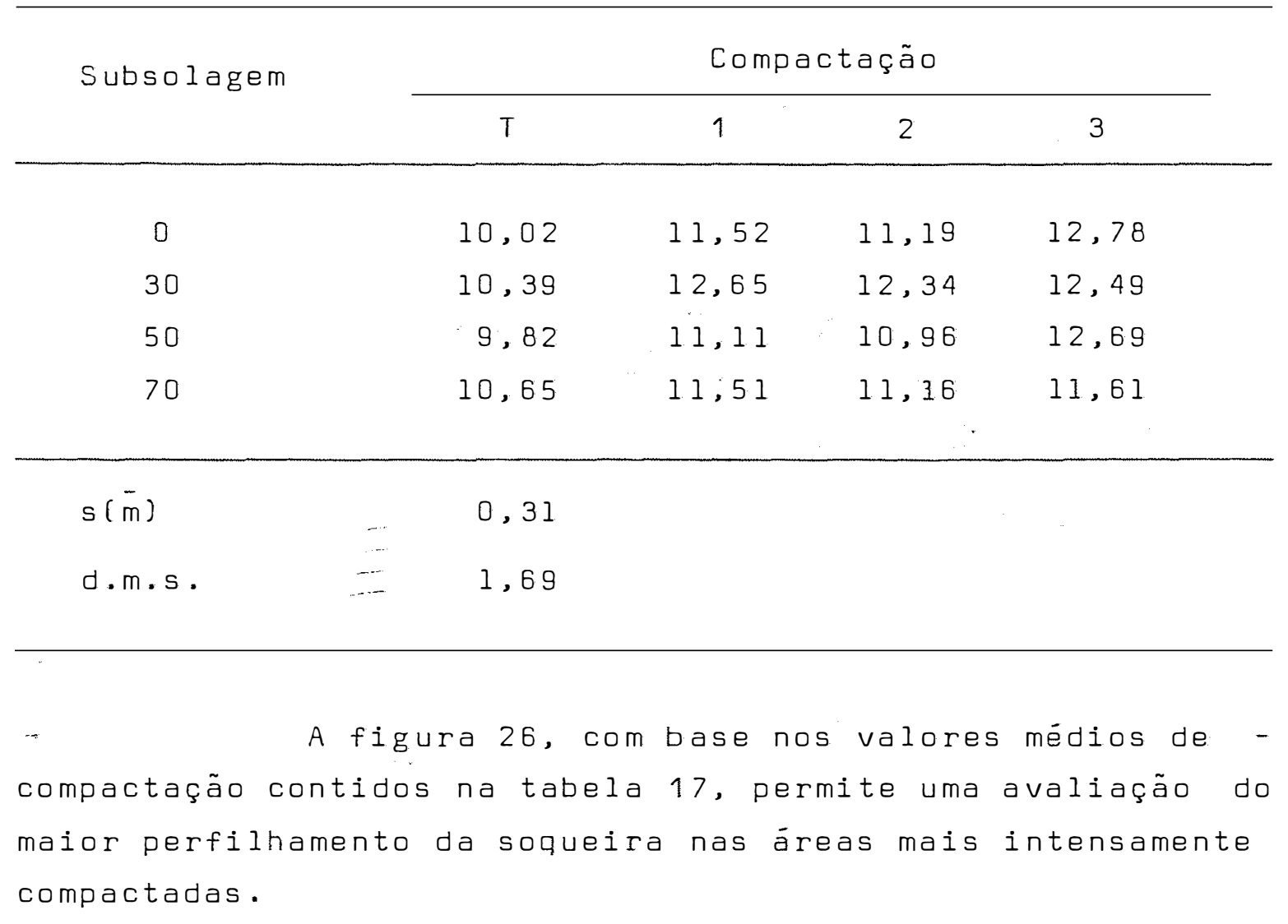




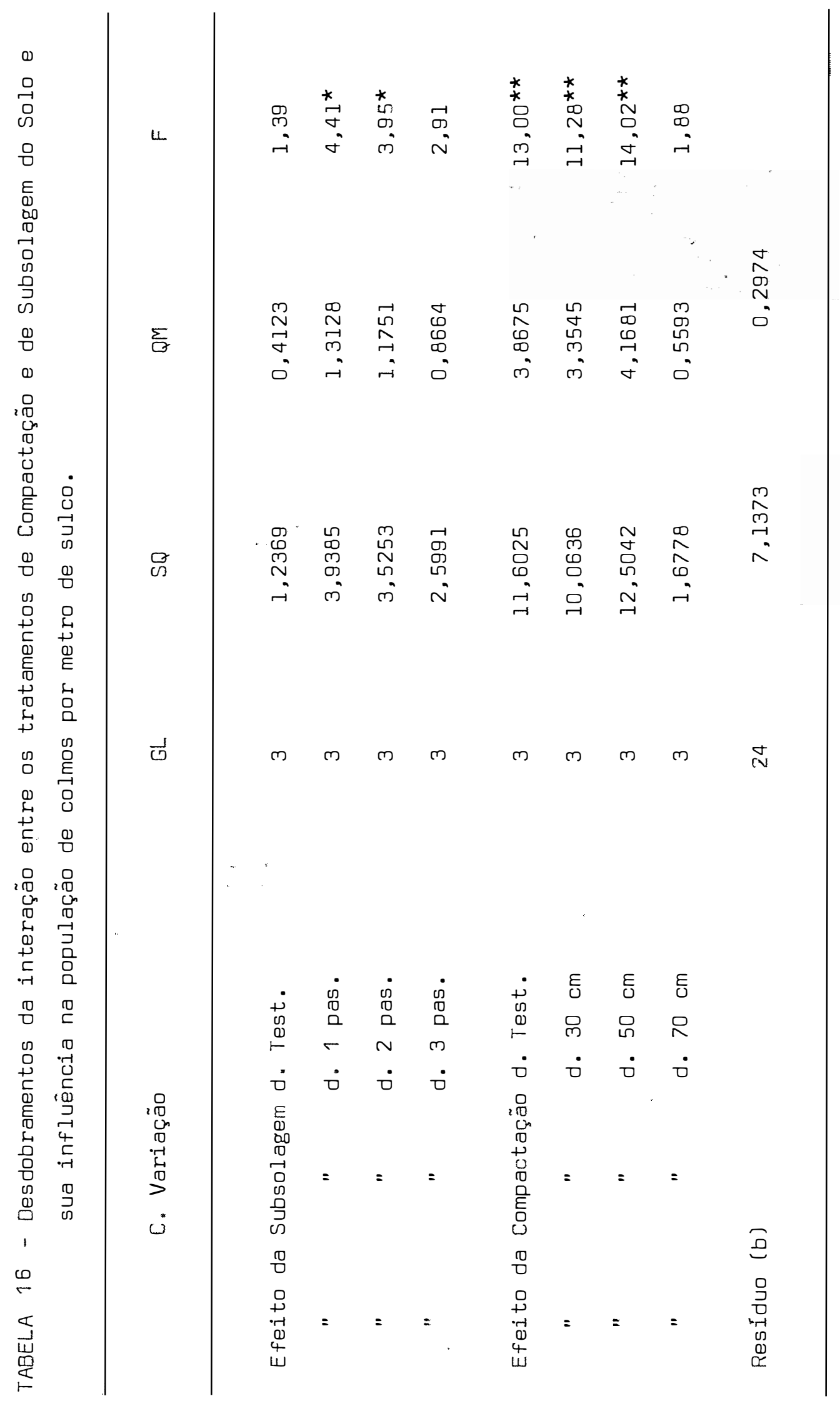


TABELA 17 - Influência da compactação do solo (incluidas as subsolagens) na população de colmos por metro de sulco. Médias das 3 repetições.

\begin{tabular}{|c|c|c|c|c|c|c|}
\hline \multirow{2}{*}{ Subsol. } & \multirow{2}{*}{ Test. } & & $N^{\circ}$ & de & Passos & \\
\hline & & 1 & & 2 & & 3 \\
\hline
\end{tabular}

$\begin{array}{lrlll}\text { Test. } & 10,02 & 11,52 & 11,19 & 12,78 \\ 30 & 10,39 & 12,65 & 12,34 & 12,49 \\ 50 & 9,82 & 11,11 & 10,96 & 12,69 \\ 70 & 10,65 & 11,51 & 11,16 & 11,61\end{array}$

$\begin{array}{llccc}\text { Soma } & 40,88 & 46,79 & 45,65 & 49,57 \\ \text { Média } & 10,22 & 11,70 & 11,41 & 12,39\end{array}$




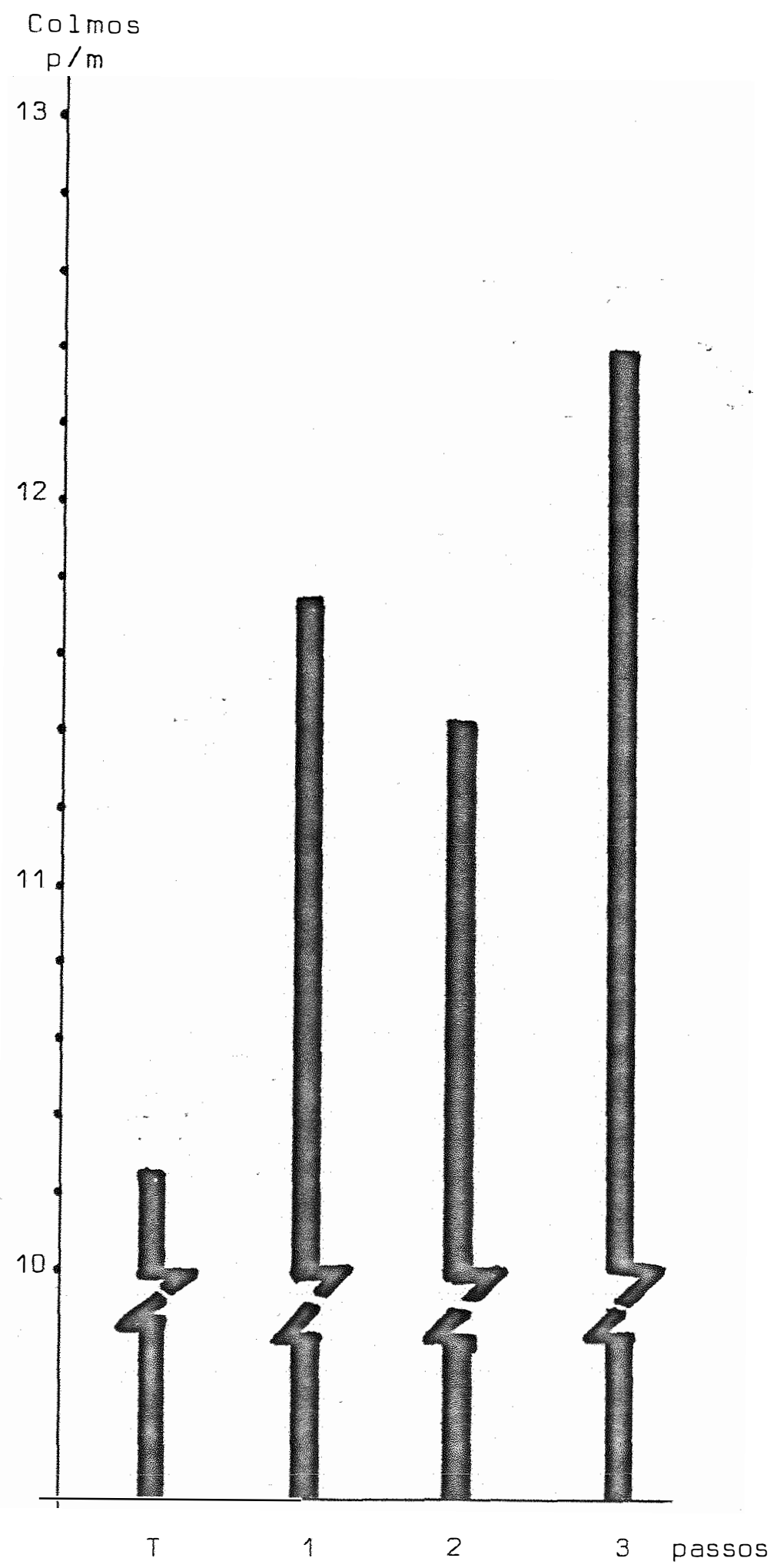

FIG. 26 - Influência da compactação do solo na população de colmos por metro de sul co. 


\subsubsection{Pesos dos cormos}

Os valores em termos de pesos por colmo são apre sentados na tabela 18 .

Os resultados da análise de variāncia constam da tabela 19, através dos quais se observa que houve signifi cáncia estatística ao nível de $1 \%$ tanto para os tratamentos de compactação quanto de subsolagém e também para a interação entre ambos.

No quadro seguinte verifica-se que não houve efeito significativo para as operações de subsolagem dentro da testemunha não compactada. Todavia, os efeitos sobre os pesos do colmo se mostraram bastante acentuados no tratamento compactada com 1 passada do veículo, embora menos evidente nos tratamentos com 2 e 3 passadas.

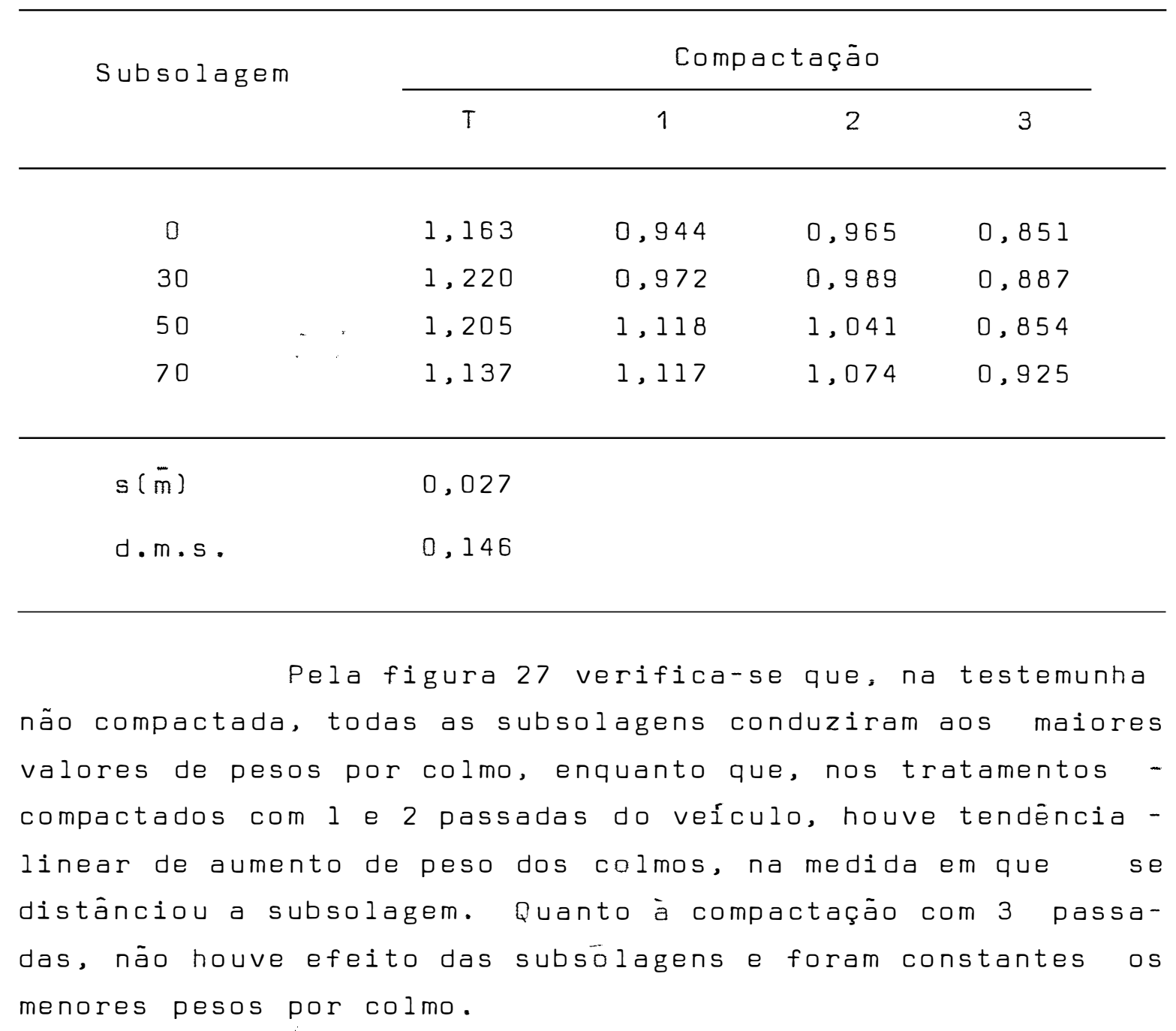


TABELA 18 - Pesos por colmo nos diferentes tratamentos.

\begin{tabular}{|c|c|c|c|c|c|c|}
\hline \multirow{2}{*}{ Passos } & \multirow{2}{*}{ Trat. } & \multicolumn{3}{|c|}{ Repetições } & \multirow{2}{*}{ Soma } & \multirow{2}{*}{ Média } \\
\hline & & I & I I & III & & \\
\hline \multirow{5}{*}{ Test. } & & & & & 。 & \\
\hline & & 1,103 & 1,128 & 1,258 & 3,489 & 1,163 \\
\hline & & 1,178 & 1,197 & 1,285 & 3,660 & 1,220 \\
\hline & & 1,294 & 1,151 & 1,169 & 3,614 & 1,205 \\
\hline & & 1,203 & 1,121 & 1,088 & 3,412 & 1,137 \\
\hline \multirow{4}{*}{1} & & 0,950 & 0,980 & 0,903 & 2,833 & 0,944 \\
\hline & & 1,031 & 0,985 & 0,900 & 2,916 & 0,972 \\
\hline & & 1,163 & 1,136 & 1,055 & 3,354 & 1,118 \\
\hline & & 1,180 & 1,090 & 1,082 & 3,352 & 1,117 \\
\hline \multirow{4}{*}{2} & & 0,962 & 0,935 & 0,997 & 2,894 & 0,965 \\
\hline & $-\quad$ : & 1,017 & 0,954 & 0,995 & 2,967 & 0,989 \\
\hline & & 1,049 & 1,020 & 1,054 & 3.123 & 1,041 \\
\hline & & 1,040 & 1,076 & 1,105 & 3,221 & 1,074 \\
\hline \multirow{4}{*}{3} & & 0,877 & 0,863 & 0,814 & 2,554 & 0,851 \\
\hline & & 0,884 & 0,916 & 0,860 & 2,660 & 0,887 \\
\hline & & 0,826 & 0,863 & 0,872 & 2,561 & 0,854 \\
\hline & & 0,838 & 0,979 & 0,958 & 2,775 & 0,925 \\
\hline
\end{tabular}




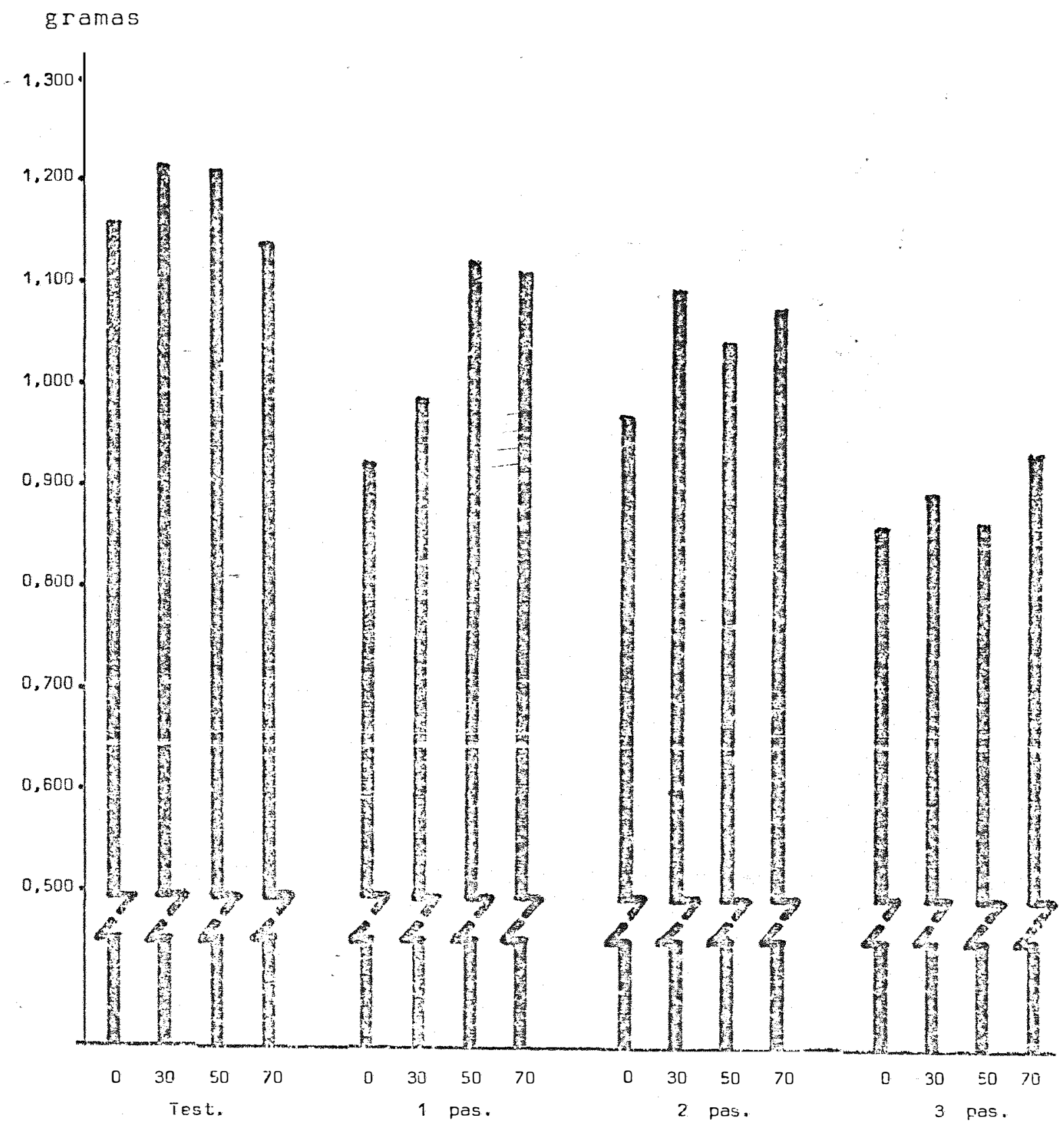

FIG. 27 - Efeitos da condiçāo de compactaęào de solo nos pesos dos colmos. 


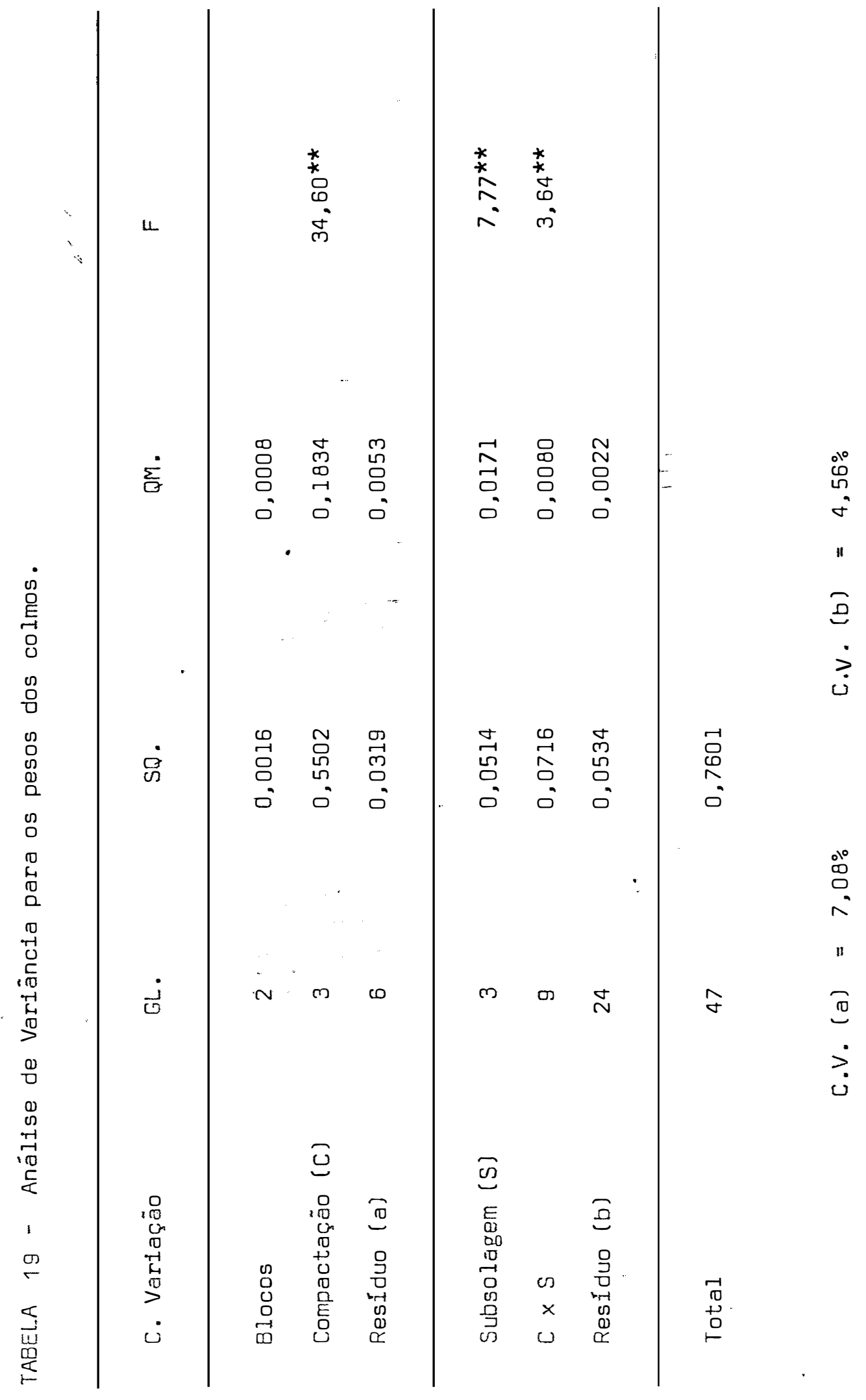




\subsubsection{Rendimentos agrícolas}

As produções de cana em toneladas por hectare são apresentadas na tabela 20. As análises de variáncia cons tam da tabela 21.

Pela análise de variáncia pode-se observar os efeitos aos níveis de $5 \%$ nos tratamentos de compactação e de $1 \%$ para as subsolagens. Esses efeitos são independentes por que não se constataram efeitos na interação de ambos os tra tamentos.

o quadro que se segue, põe em evidéncia os efei tos da subsolagem no tratamento compactado com 1 passada do veículo. A despeito dá baixa produção obtida na parcela não subsolada, o rendimento médio final desse tratamento equipa rou-se com o do tratamento testemunha, não compactado. Esses resultados são ilustrados pela figura 28 , elaborada a partir dos valores da tabela 20.

\begin{tabular}{cccc}
\hline Compactação & \multicolumn{2}{c}{ Subsolagem } \\
\hline$T$ & 86,17 & 0 & 78,94 \\
1 & 86,48 & 30 & 86,17 \\
2 & 82,87 & 50 & 83,00 \\
3 & 77,67 & 70 & 85,11 \\
\hline $\mathrm{s}(\overline{\mathrm{m}})$ & 1,71 & & \\
$\mathrm{~d} \cdot \mathrm{m} . \mathrm{s}$. & 8,38 & & 1,18 \\
\hline
\end{tabular}


TABELA 20 - Produçōes em toneladas de cana por hectare.

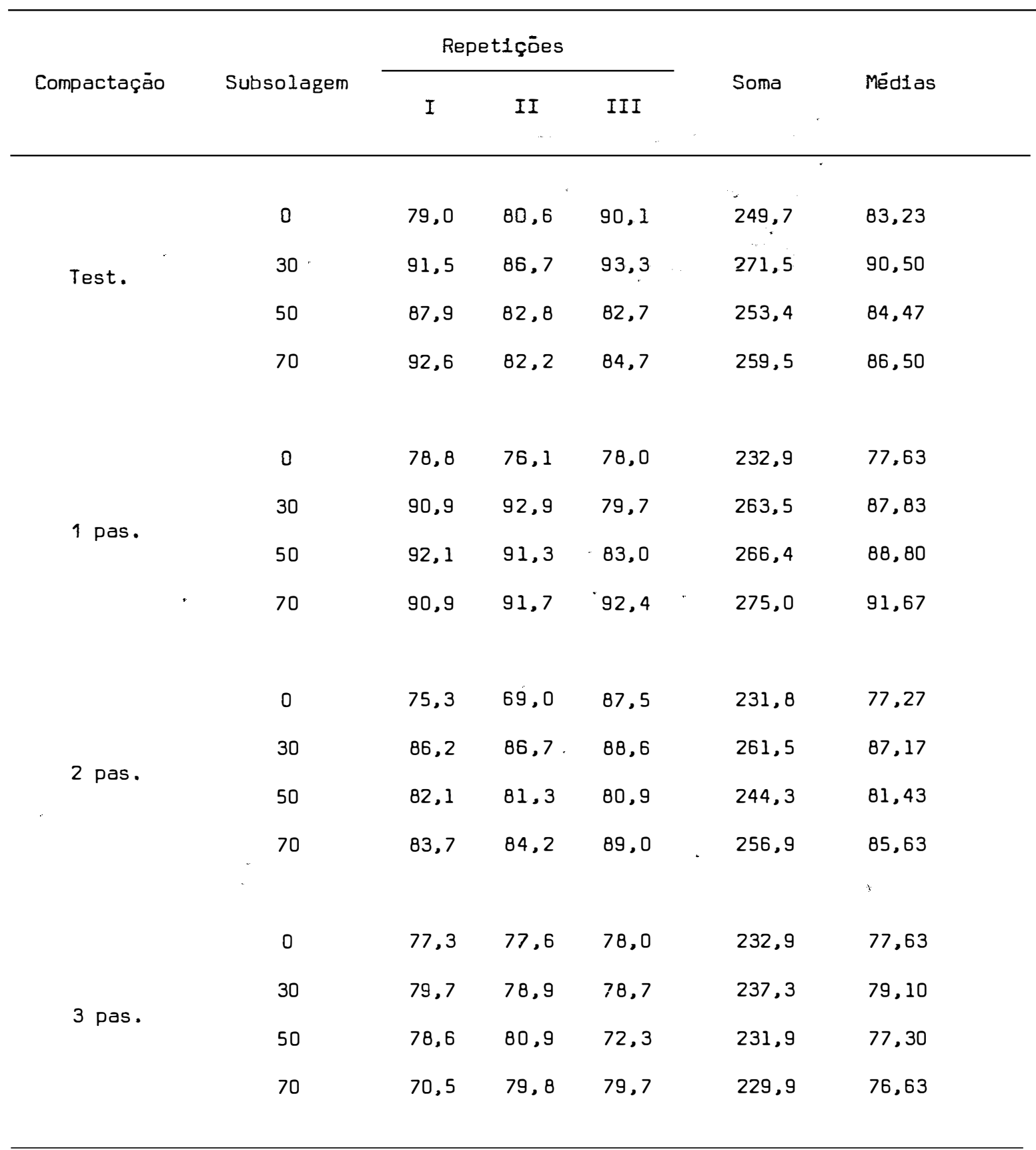




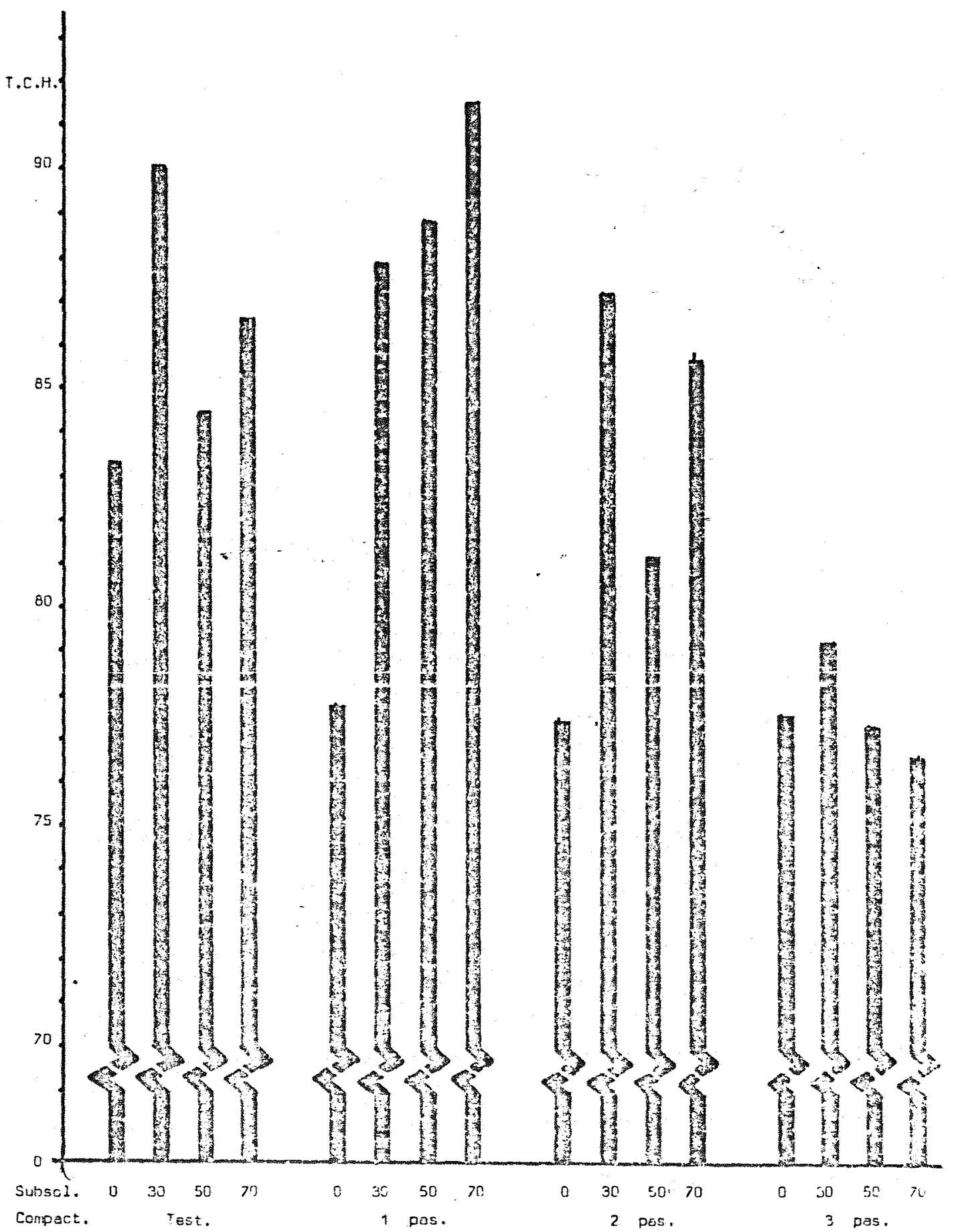

FIG. 28-Representação das produçōes em tonedadas de cano por hiectars nos diferentes tratamürios,

Médias das 3 refietiçóes. 


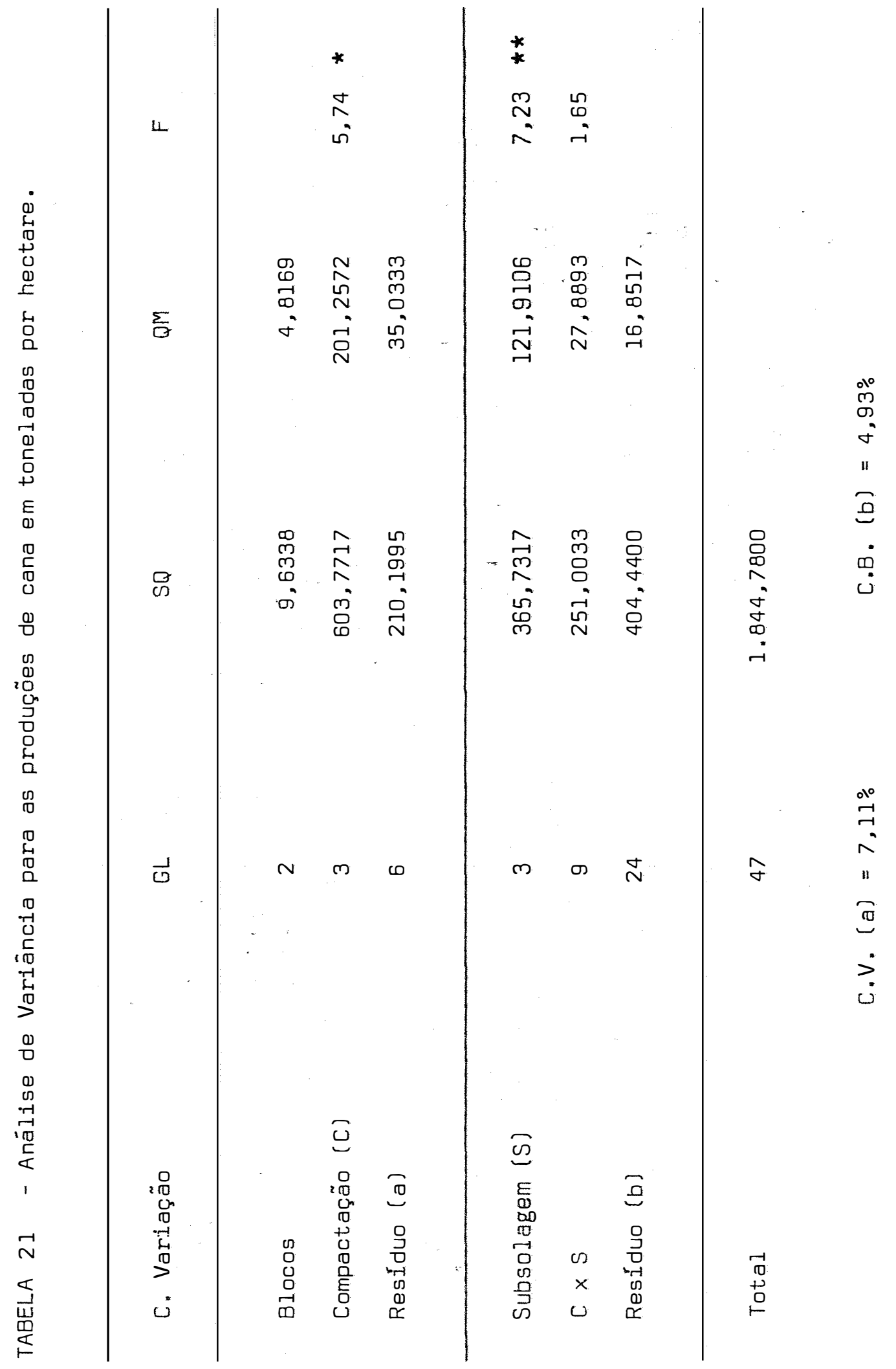


Entretanto, os efeitos das subsolagens decresceram nos tratamentos mais compactados, chegando a não mostrar nenhum efeito significativo em relação à testemunha não subsolada quando o veículo passou 3 vezes na ärea, conforme se pode observar no quadro que se segue:

\begin{tabular}{|c|c|c|c|c|}
\hline \multirow{2}{*}{ Subsolagem } & \multicolumn{4}{|c|}{ Compactação } \\
\hline & $T$ & 1 & 2 & 3 \\
\hline 0 & 83,23 & 77,63 & 77,27 & 77,63 \\
\hline 30 & 90,50 & 87,83 & 87,16 & 79,10 \\
\hline 50 & 84,47 & 88,80 & 81,43 & 77,30 \\
\hline 70 & 86,50 & 91,67 & 85,63 & 76,63 \\
\hline$s(\bar{m})$ & 2,37 & & & \\
\hline$d \cdot m \cdot s$. & 12,75 & & & \\
\hline
\end{tabular}

A tabela 22, ilustrada pela figura 29, deixam evidentes as diferenças verificadas nos rendimentos agrícolas nos diferentes tratamentos de compactação, quando realizadas ou não as operações de subsolagem.

\subsection{Anāilise tecnolōgica}

Os resultados das análíses de Brix, Polarização na Cana e Pureza, são apresentados na tabela 23.

Não parece ter havido influência dos diferentes tratamentos de solo sobre a qualidade do caldo da cana. 
TABELA 22 - Produções de cana em toneladas por hectare nos Tratamentos de Compactaçāo Com e Sem subsolagem posterior.

\begin{tabular}{|c|c|c|c|c|c|c|}
\hline \multirow{2}{*}{ Compactaçāo } & \multirow{2}{*}{$\begin{array}{l}\text { Trat. sem } \\
\text { Subsolagem }\end{array}$} & \multicolumn{2}{|c|}{ Tratamentos } & \multicolumn{2}{|c|}{ com Subsolagem } & \multirow[b]{2}{*}{ Médias } \\
\hline & & $30 \mathrm{~cm}$ & $50 \mathrm{~cm}$ & $70 \mathrm{~cm}^{-}$ & Soma & \\
\hline Test. & 83,23 & 90,50 & 84,47 & 86,50 & 261,47 & 87,15 \\
\hline 1 pas. & 77,63 & 87,83 & 88,80 & 91,67 & 268,30 & 89,43 \\
\hline 2 pas. & 77,27 & 87,17 & 81,43 & 85,63 & 254,23 & 84,74 \\
\hline 3 pas. & 77,63 & 79,10 & 77,30 & 76,63 & 233,03 & 77,67 \\
\hline
\end{tabular}


T.C.H.

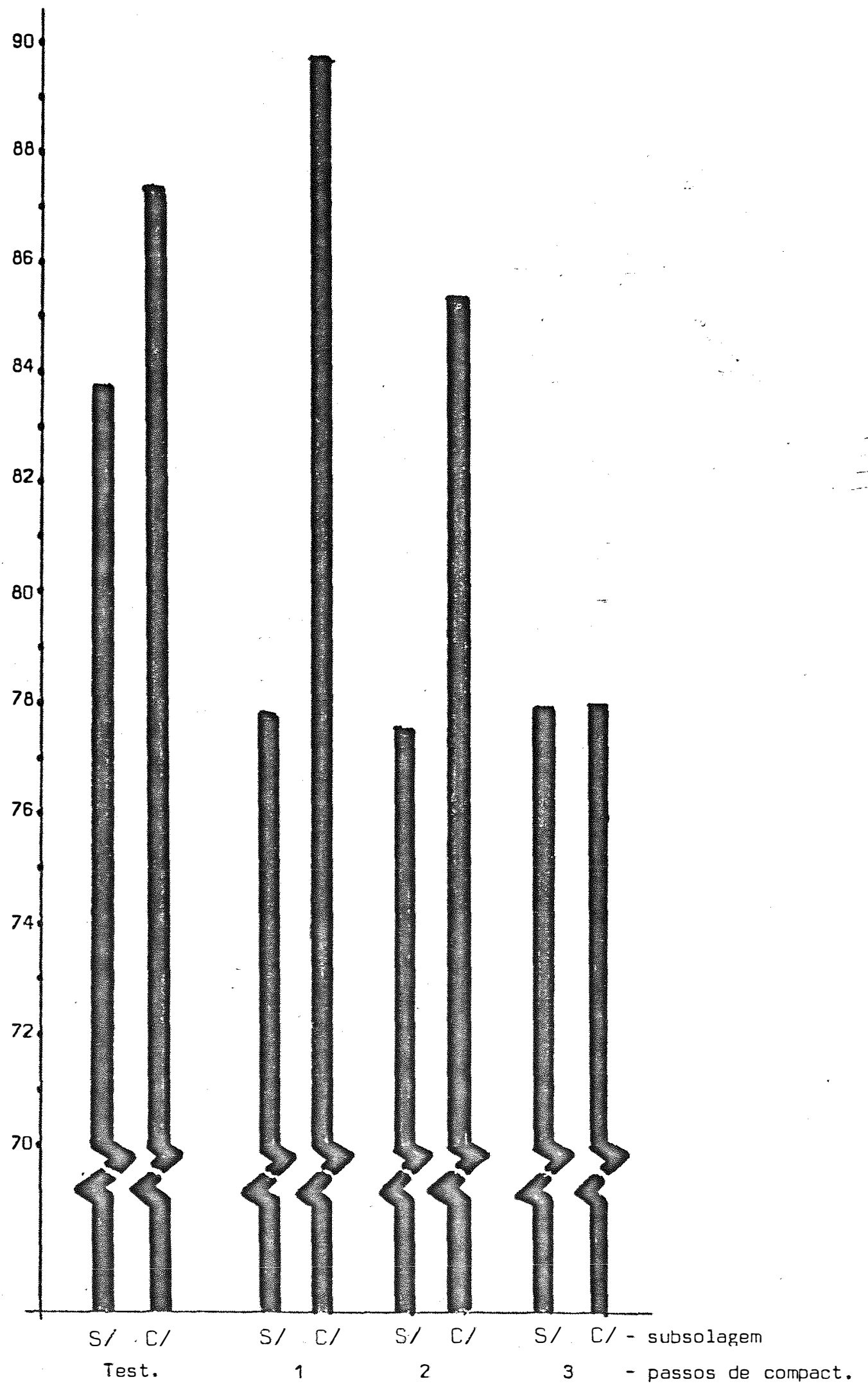

FIG. 29 - Produçào de cana nos tratamentos com (C) e sem (S) subsolagem, na ärea testemunha (não compactada) e nos tratamentos compactados. 
TABELA 23 - Análises tecnológicas obtidas com amostras de 10 colmos. Resultados médios das 3 repetições.

\begin{tabular}{|c|c|c|c|c|}
\hline Compactação & Subsolagem & Brix & $\begin{array}{l}\text { Pol na } \\
\text { Cana }\end{array}$ & Pureza \\
\hline \multirow{4}{*}{ Test. } & 0 & 16,75 & 14,69 & 87,70 \\
\hline & 30 & 16,62 & 14,61 & 87,91 \\
\hline & 50 & 16,71 & 15,01 & 89,82 \\
\hline & 70 & 16,69 & 14,49 & 89,51 \\
\hline \multirow{5}{*}{1 pas. } & & & & \\
\hline & 0 & 16,78 & 15,22 & 90,70 \\
\hline & 30 & 16,59 & 14,88 & 89,69 \\
\hline & 50 & 16,69 & 15,12 & 90,59 \\
\hline & 70 & 16,80 & 15,20 & 90,48 \\
\hline \multirow{4}{*}{2 pas. } & 0 & 16,81 & 15,18 & 90,30 \\
\hline & 30 & 16,68 & 14,87 & 89,15 \\
\hline & 50 & 16,74 & 14,92 & 89,13 \\
\hline & 70 & 16,85 & 15,21 & 90,27 \\
\hline \multirow{4}{*}{3 pas. } & 0 & 16,92 & 15,28 & 90,31 \\
\hline & 30 & 16,28 & 14,96 & 91,89 \\
\hline & 50 & 15,96 & 14,55 & 91,16 \\
\hline & 70 & 16,37 & 14,42 & 88,09 \\
\hline
\end{tabular}




\subsection{Sistema Radicular}

A tabela 24 mostra o quadro geral das pesagens das raízes em gramas de matéria seca. Cada pesagem represen ta as raízes contidas em uma amostra formada por um cubo de terra medindo $20 \times 20 \times 20 \mathrm{~cm}(8$ litros). Foram 35 amostras retiradas de cada trincheira, totalizando 560 amostras.

Nas tabelas 25 a 40 são representadas as trin cheiras dos 16 tratamentos com as localizações das 35 amostras retiradas em ambos os lados da linha de soqueira e cor respondentes às 2 repetiêöes. Os valores em pesos das raizes referem-se à médias obtidas.

A tabela 41 mostra esses valores, permitindo uma avaliação em conjunto.

As figuras 30 a 45 representam esquematicamente as distribuições percentuais das raízes no sentido horizontal (a partir do centro do sulco até a entrelinha) e no sentido vertical (através dos perfís do solo) cada 20 cm até $100 \mathrm{~cm}$ de profundidade.

Pode-se notar que não se verificaram acentuadas diferenças em função dos vários tratamentos de compctação e de subsolagem.

As figuras 46 a 49 e 50 a 53 mostram esses mes mos comportamentos das raizes, com os efeitos acumulados nos vários pontos de referéncia em ambos os sentidos.

Essa forma de representação confirma a interpretação anterior, apenas podendo-se destacar que, nos tratamentos com 2 e 3 passadas do veículo, houve ligeira redü ção na proliferação das raízes nas primeiras camadas de 0 a $20 \mathrm{~cm}$ e de 20 a $40 \mathrm{~cm}$.

A distribuição das raízes através do perfil do solo a cada $20 \mathrm{~cm}$ de profundidade é mostrada na tabela 42. Na última coluna é apresentada a concentração em porcentagem das raizes na camada superior até $40 \mathrm{~cm}$ de profundidade, cu jos valores são transferidos para a figura 54. 
Com base também nas informações contidas na tabela 25 a 40 foi preparada a tabela 43 , contendo a distribuição do sistema radicular no sentido horizontal, a partir do centro do sulco até o centro da entrelinha $(70 \mathrm{~cm})$. Os valores da última coluna compõem a figura 55.

Ambas as representações gräficas permitem con firmar as conclusões anteriores quanto à pequena influéncia provocada pelas condições de densidade do solo na proliferação e distribuição das raízes, observadas nas circunstâncias do experimento.

Correlacionando esse aspecto referente ao volu me das raízes cōm as produções obtidas nos diferentes tratamentos, vamos encontrar coeréncias com as observações encon tradas em HUMBERT (1974). $-$

Ainda sobre a atividade das raizes, HUMBERT (1974), TROUSE \& HUMBERT (1961), MONTEITH \& BANATH (1965) $e$ TROUSE Jr. (1967), fazem referencias a restrições quanto ao desempenho do sistema radicular da cana-de-açücar em solos cujas densidades aparentes ultrapassem 1,2 a 1,25. Segundo esses pesquisadores, ainda que o sistema radicular mostre um volume aparente satisfatório, as raizes podem apresentar de formações durante o crescimento, além da deficiente proliferação das radicellas. 


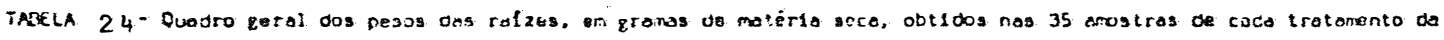
2n. repaticjo.

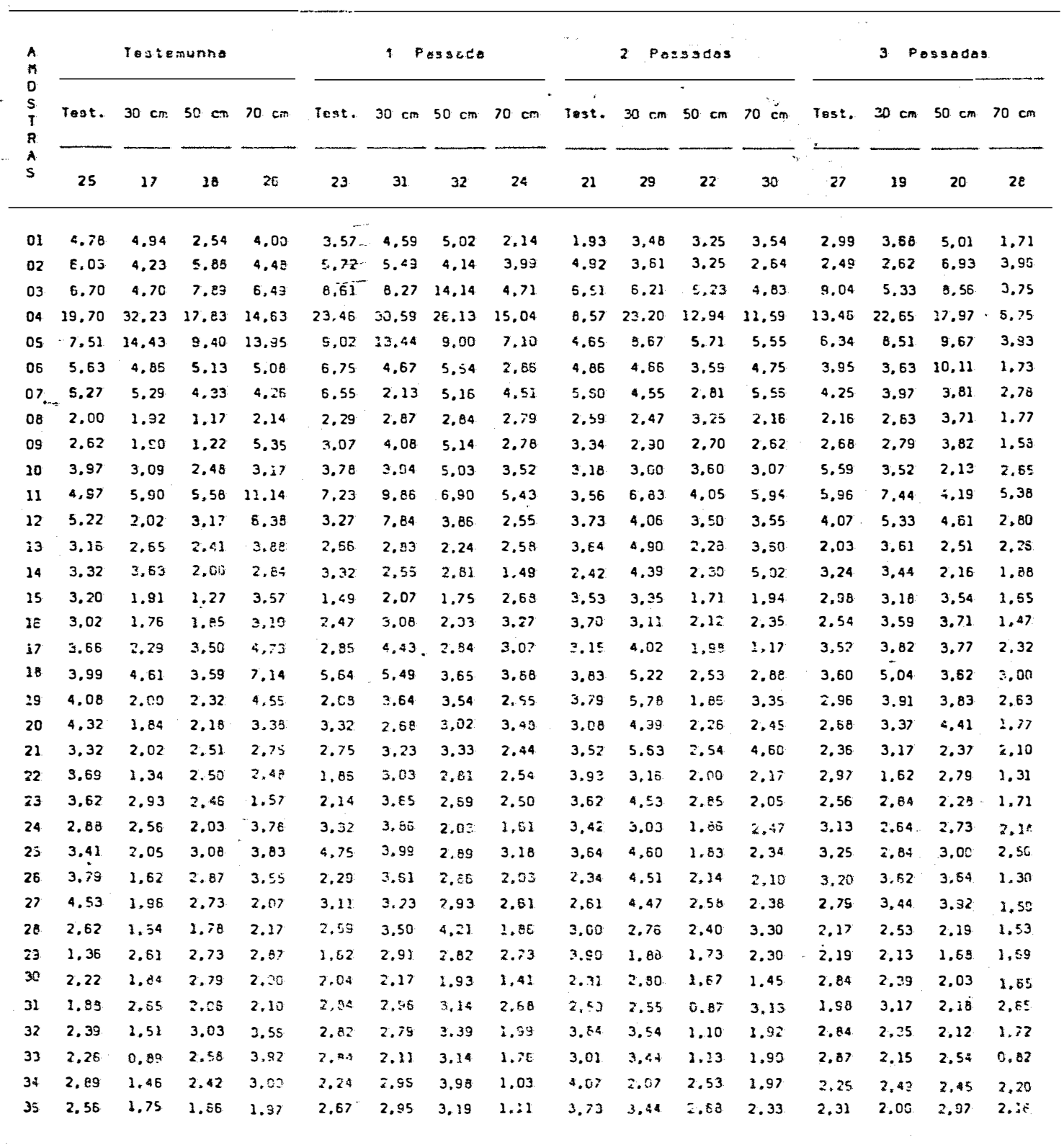




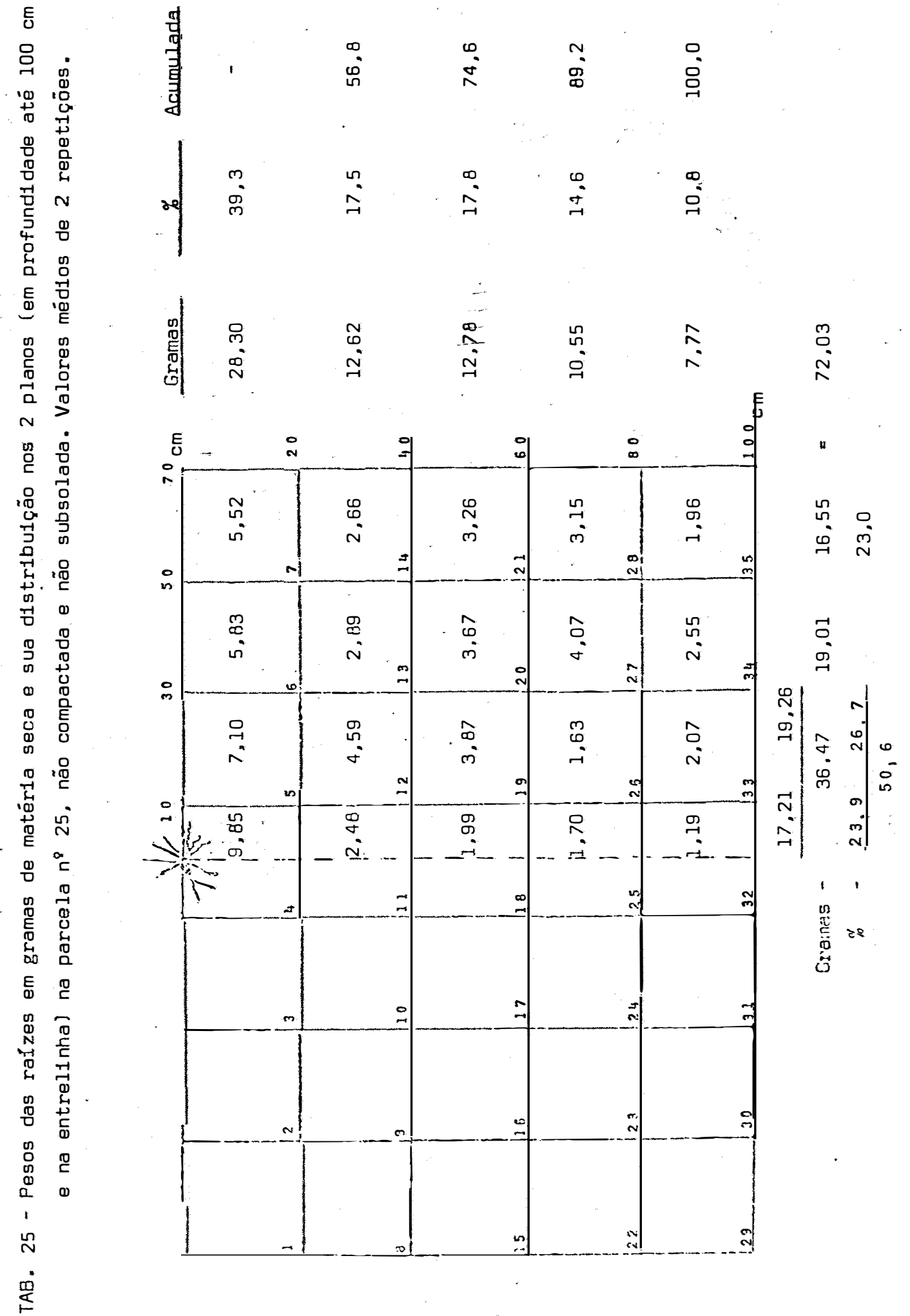




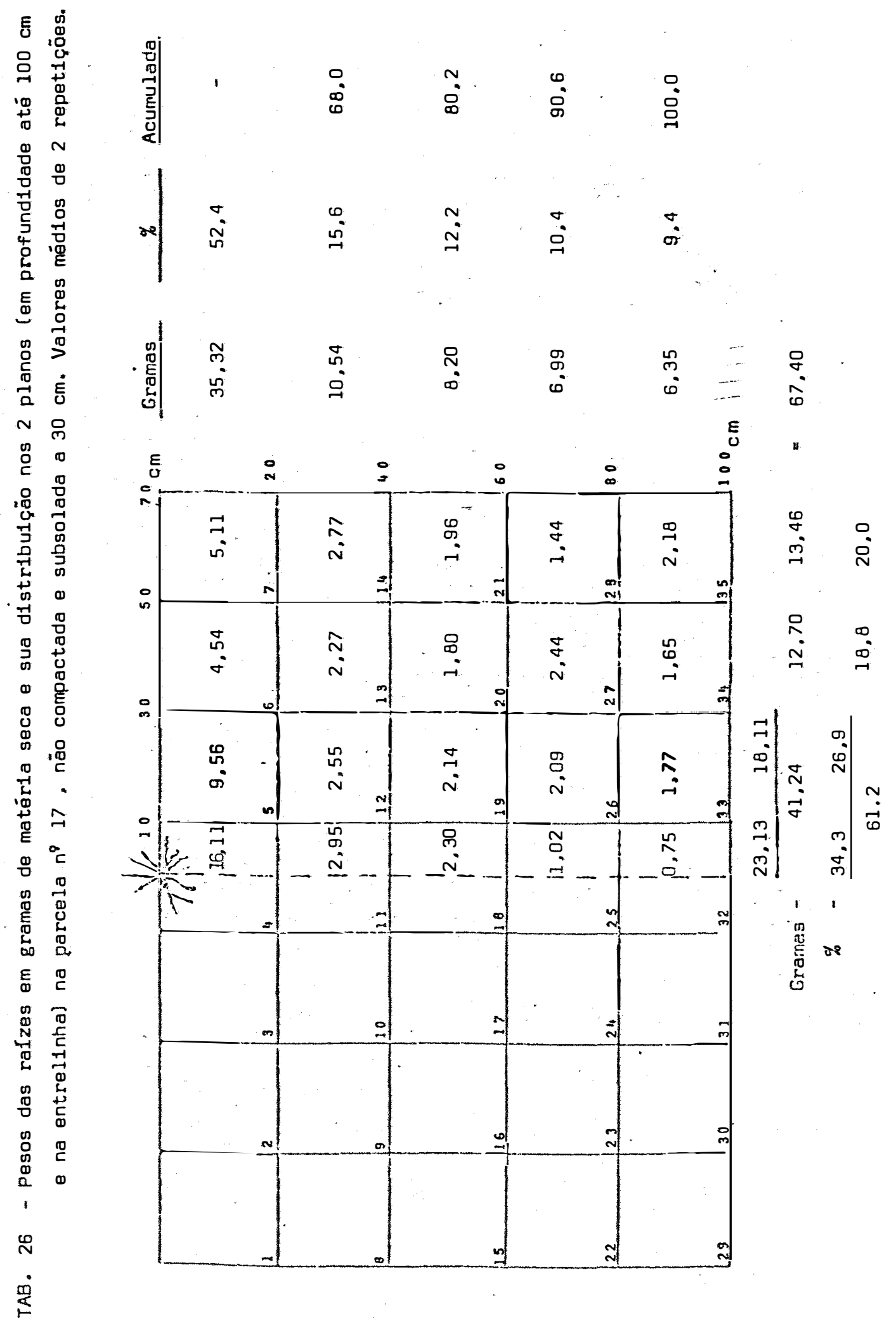




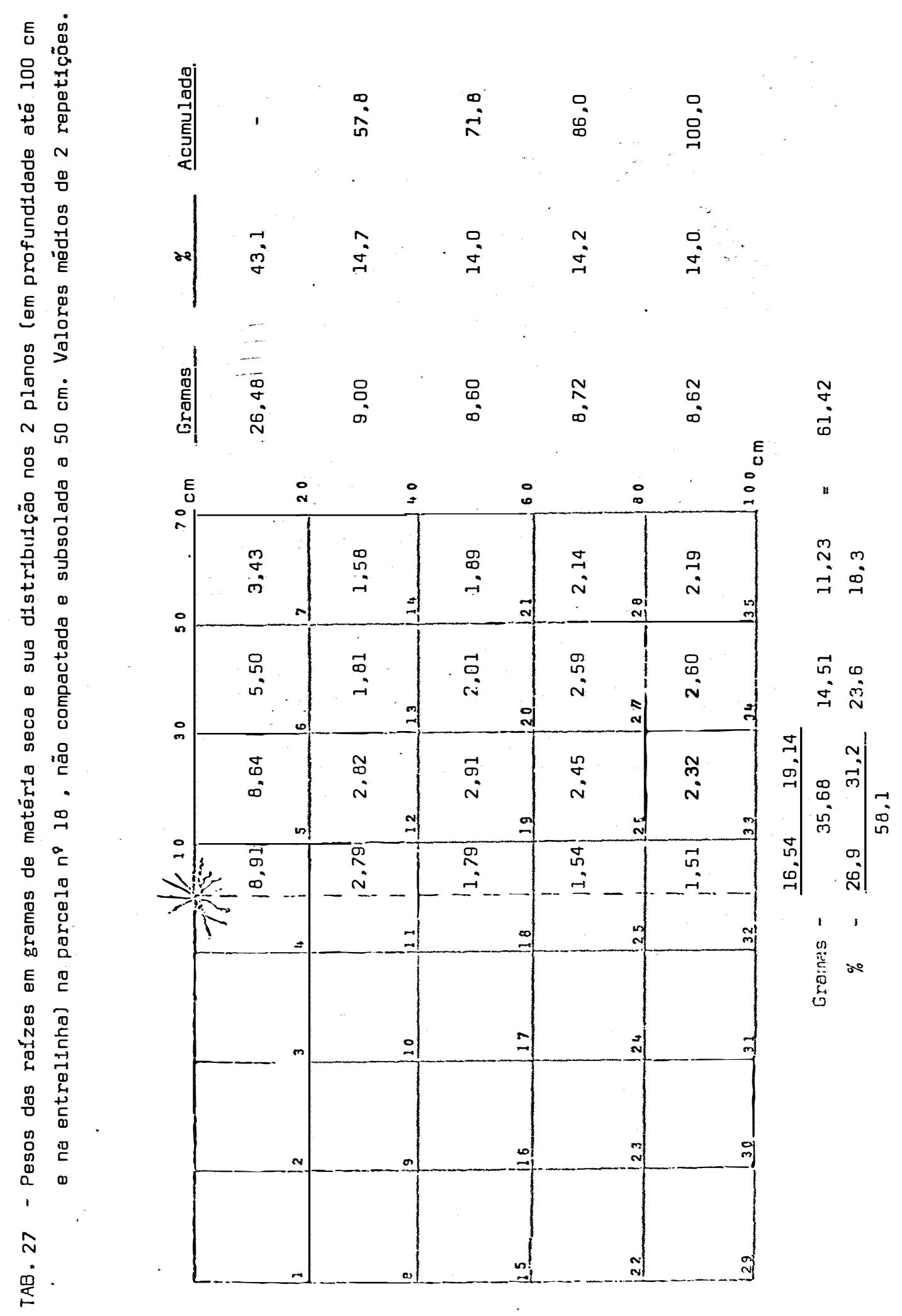




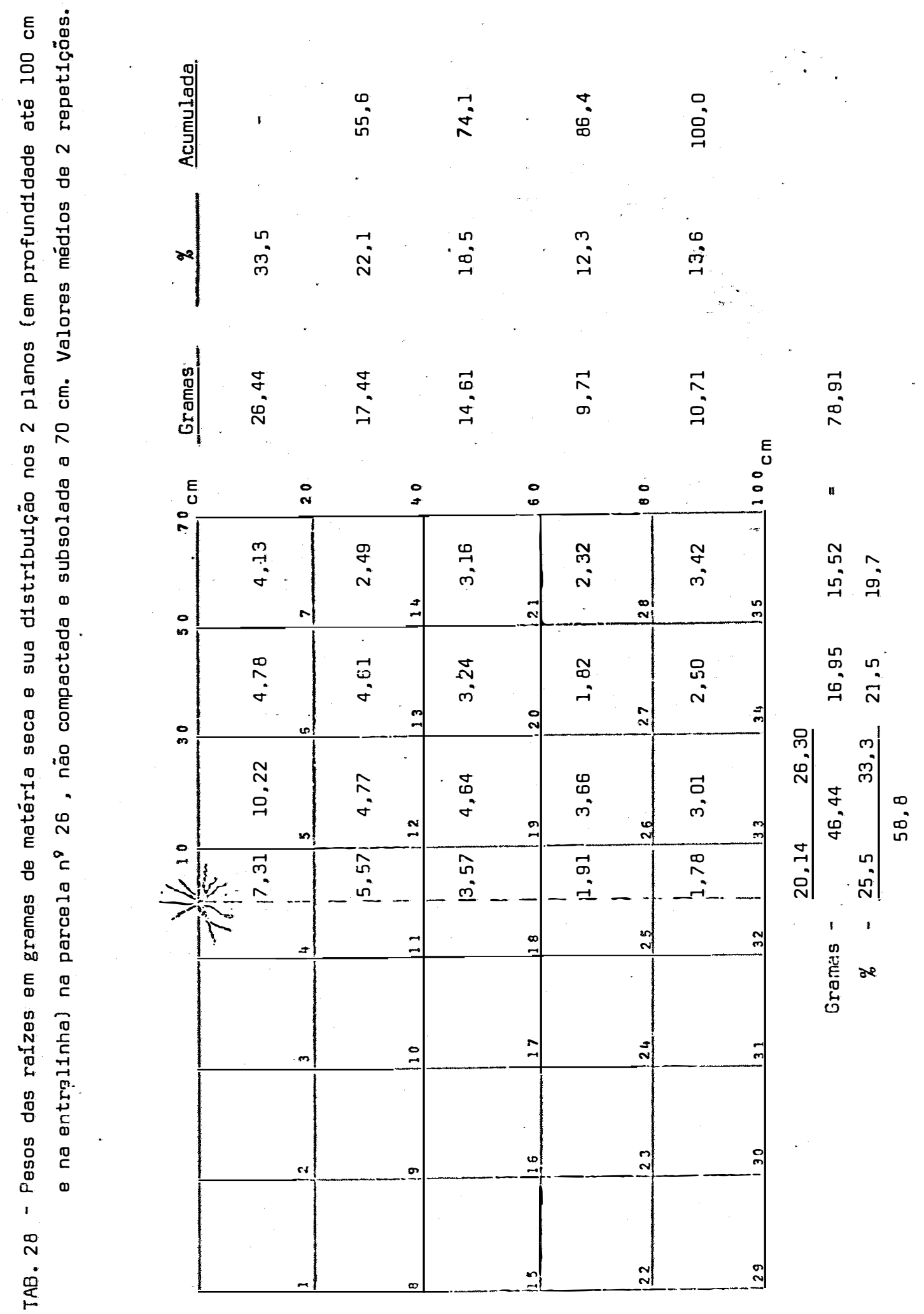




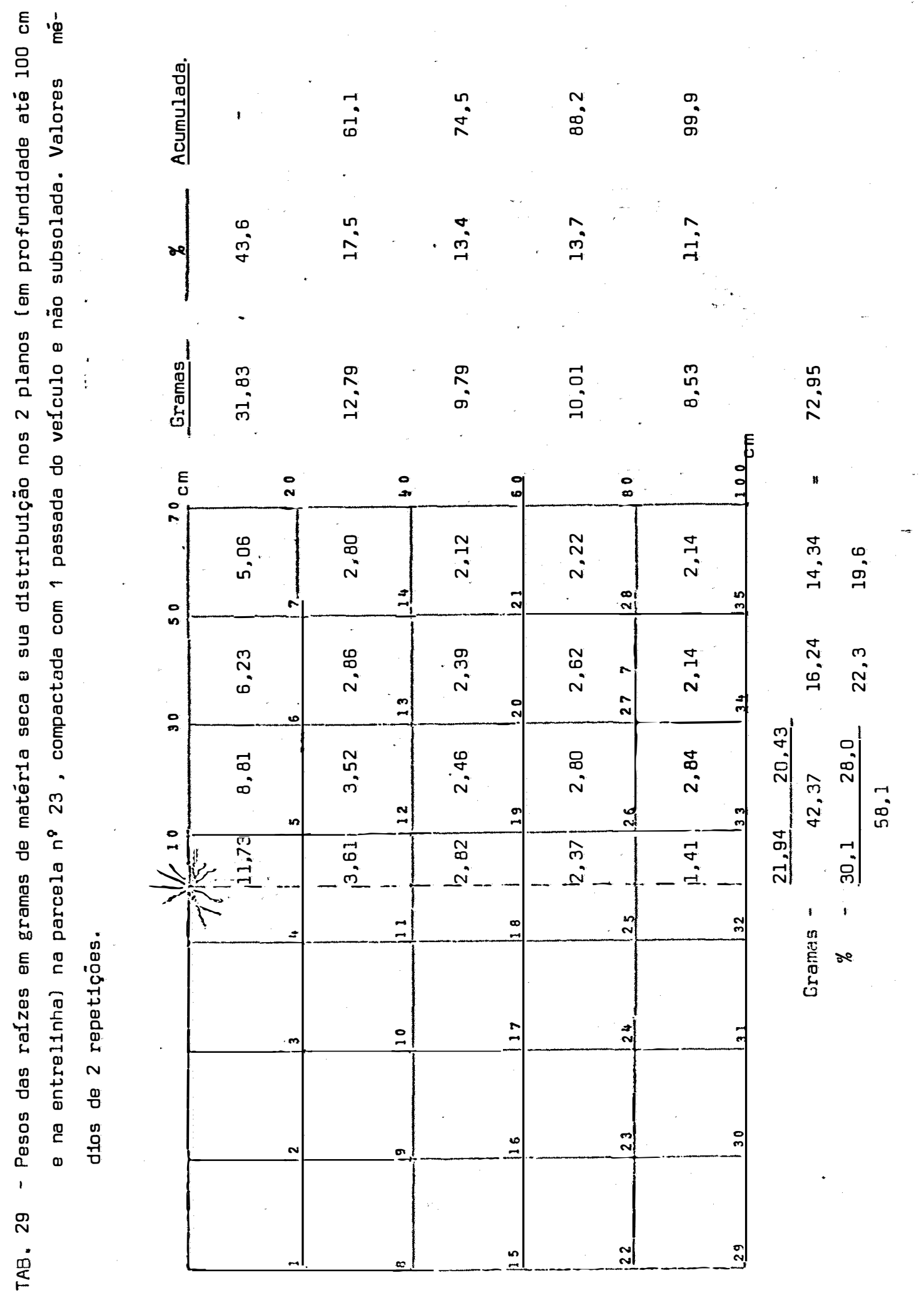




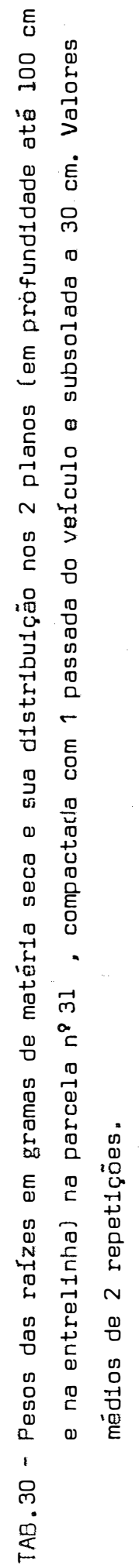

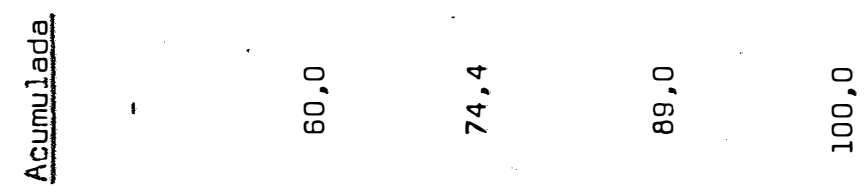

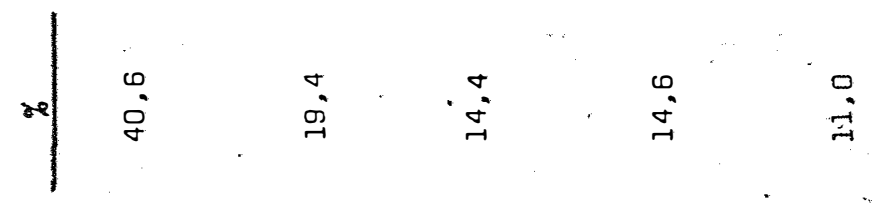

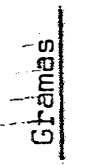

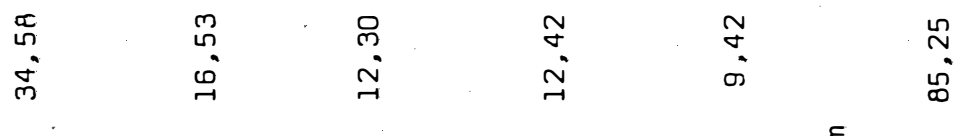
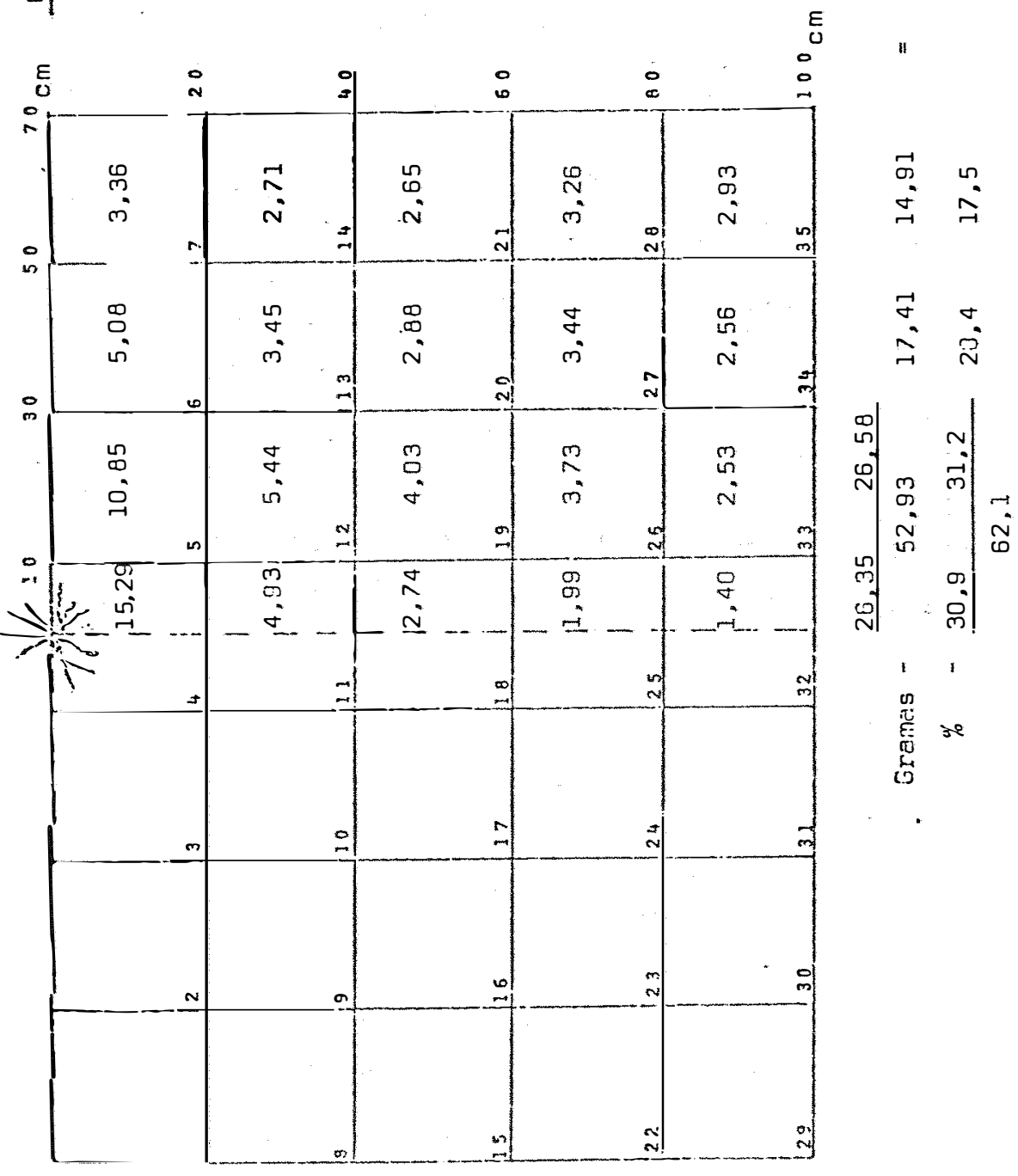


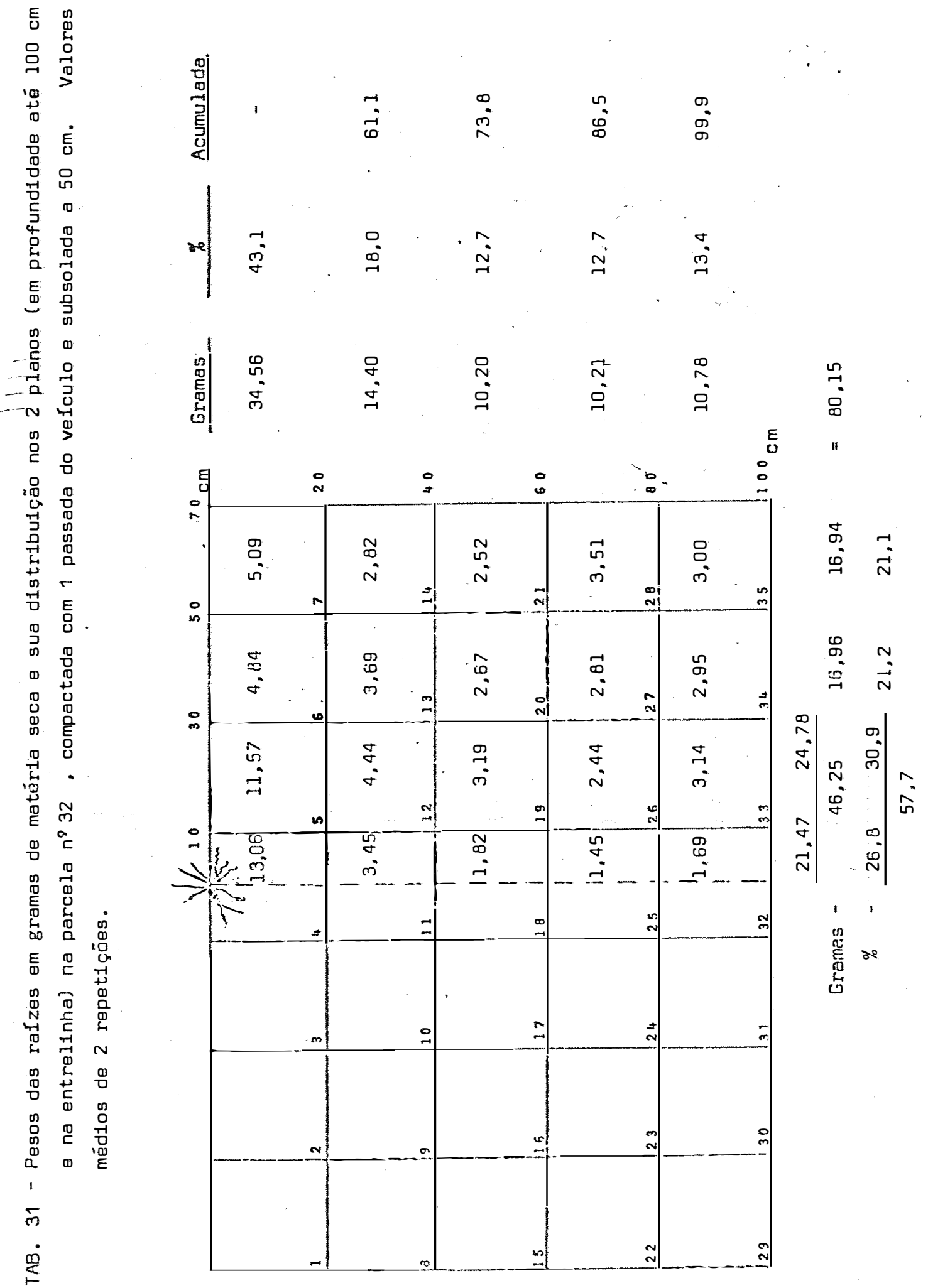




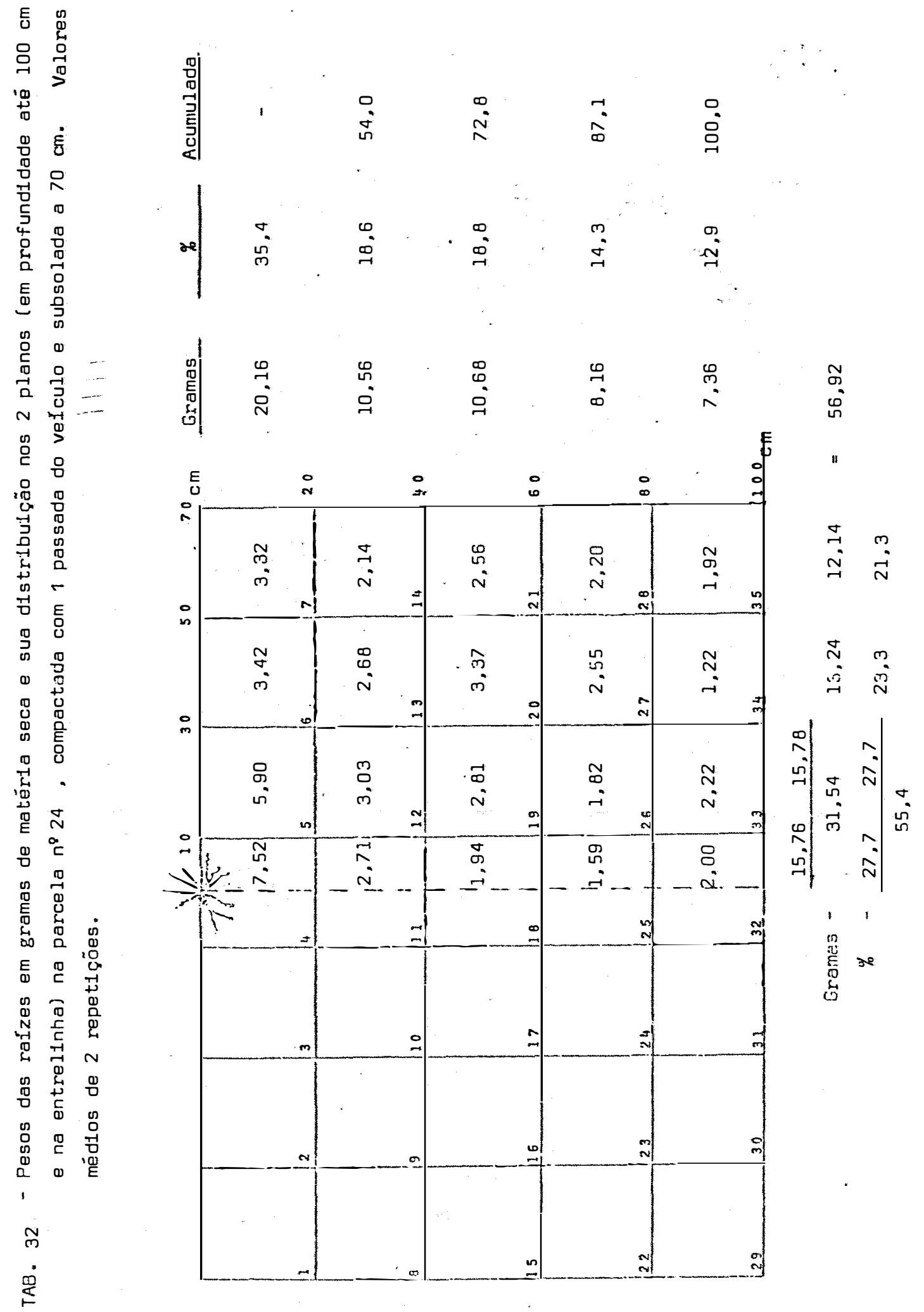




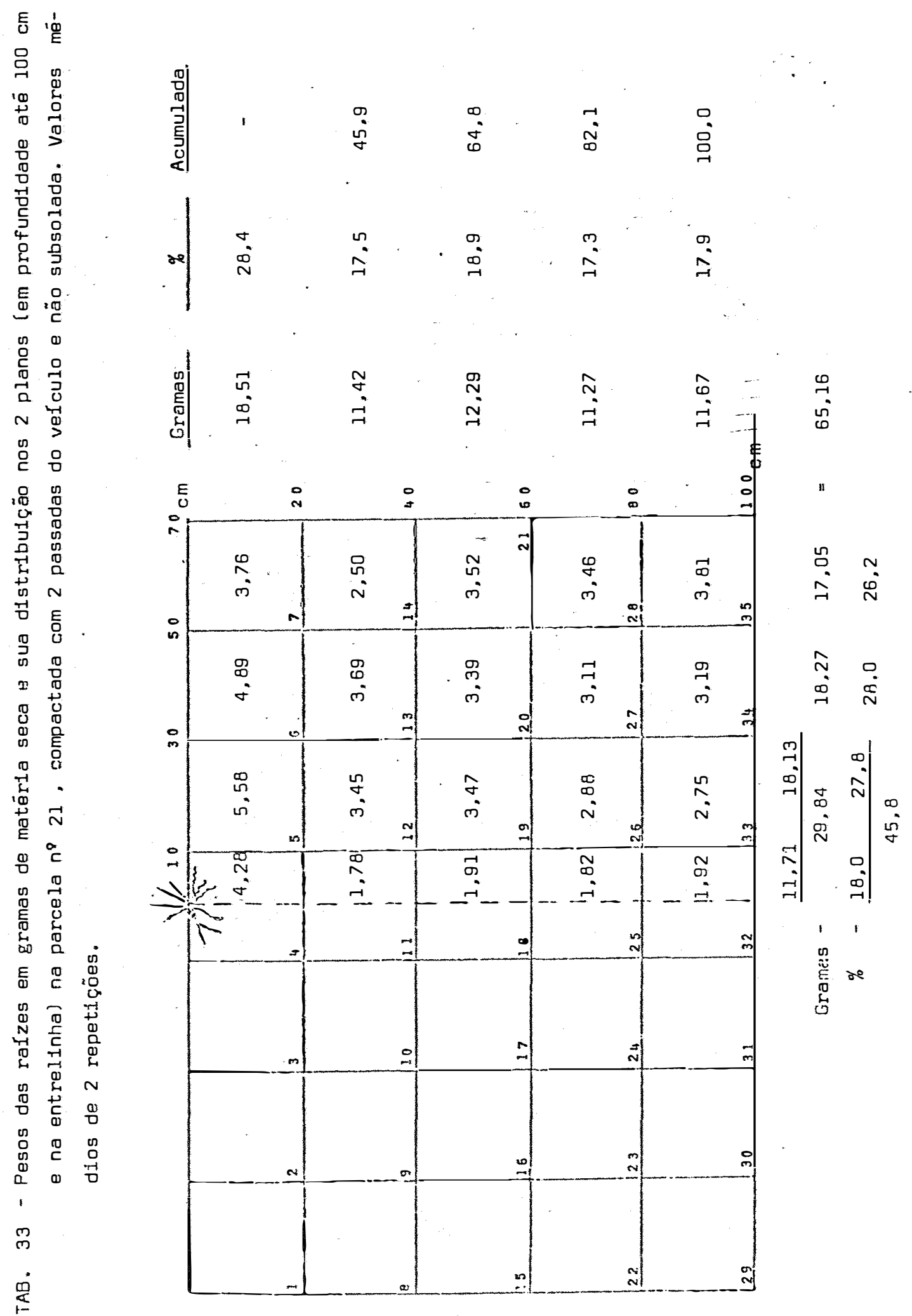




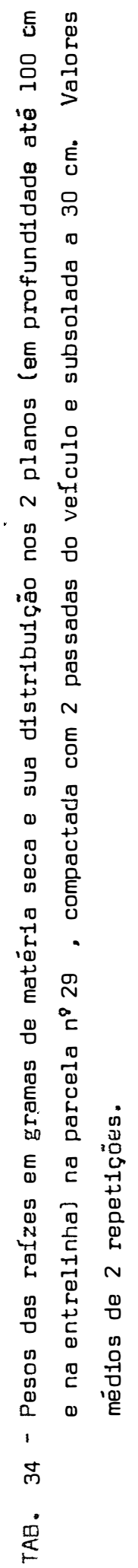

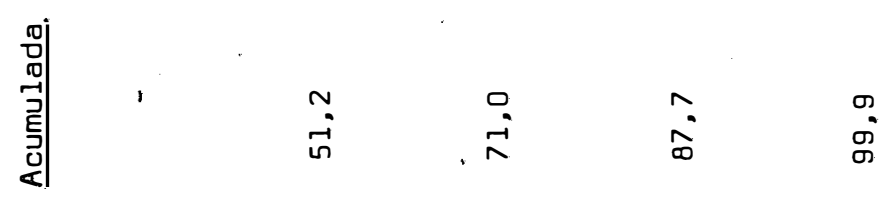
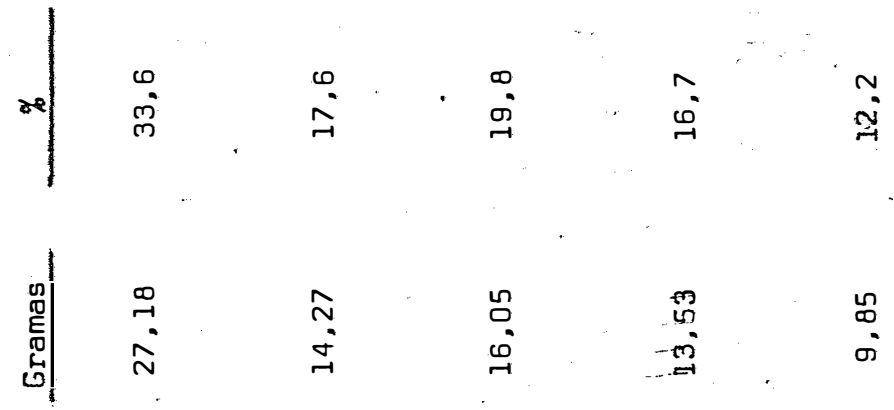

$\begin{array}{ll}\infty & \infty \\ \infty & \infty\end{array}$

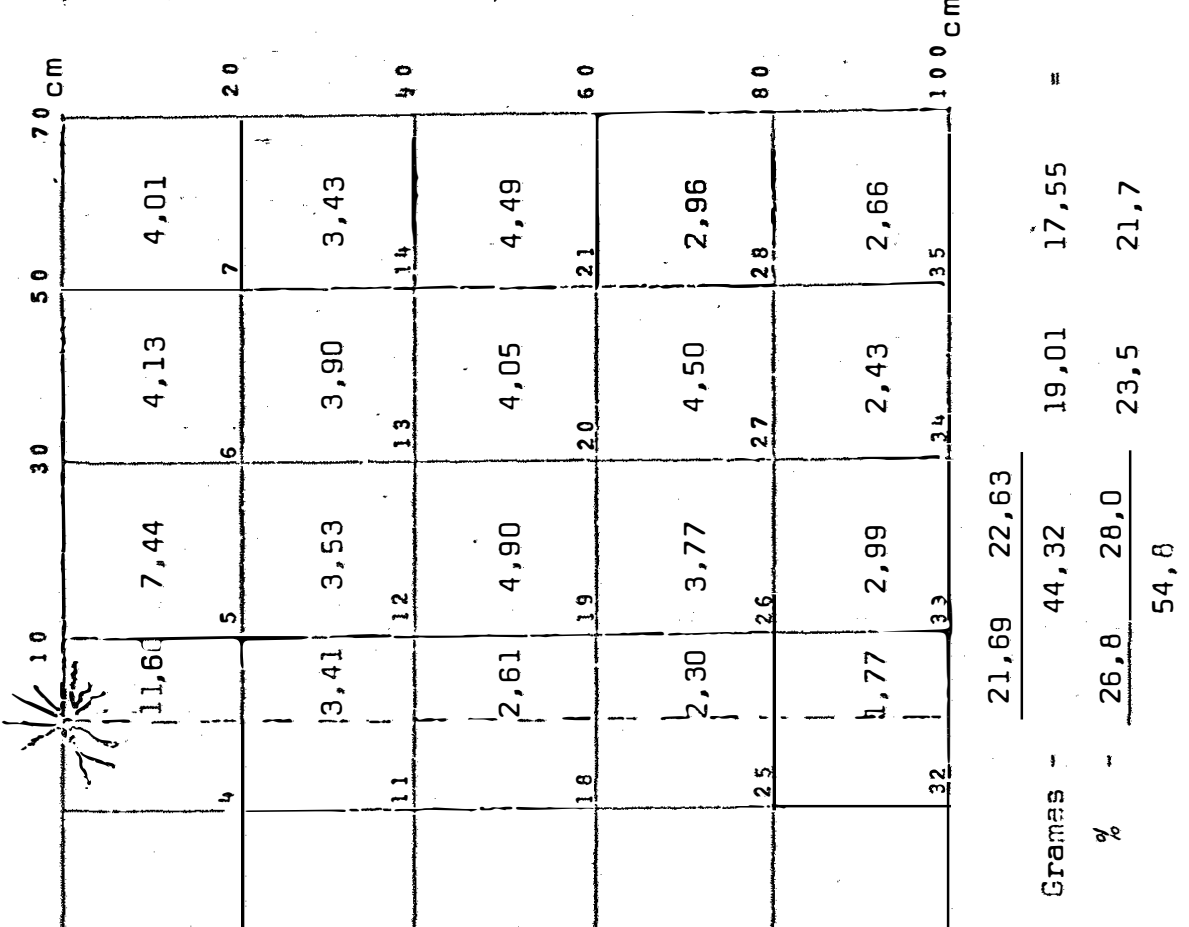




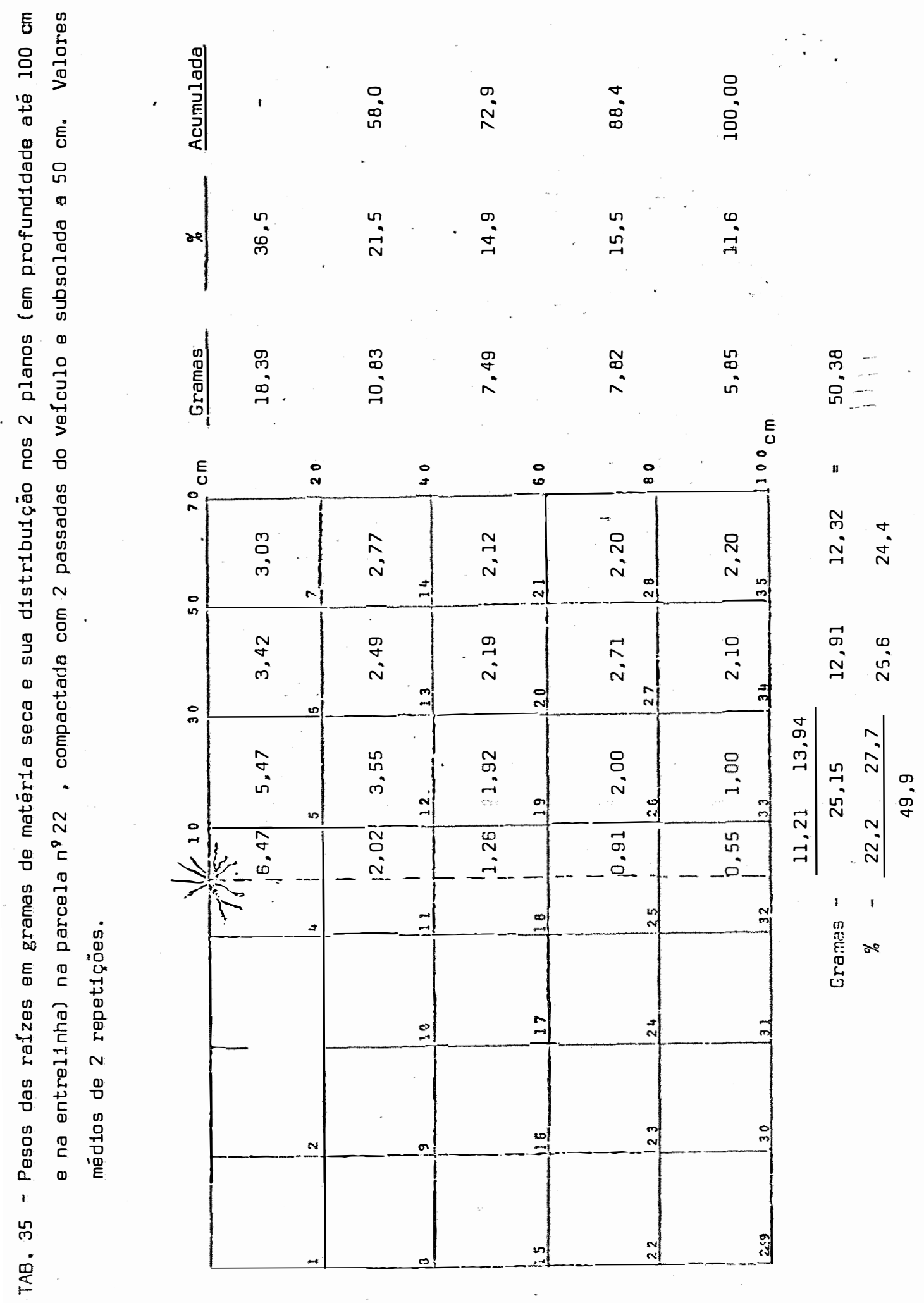




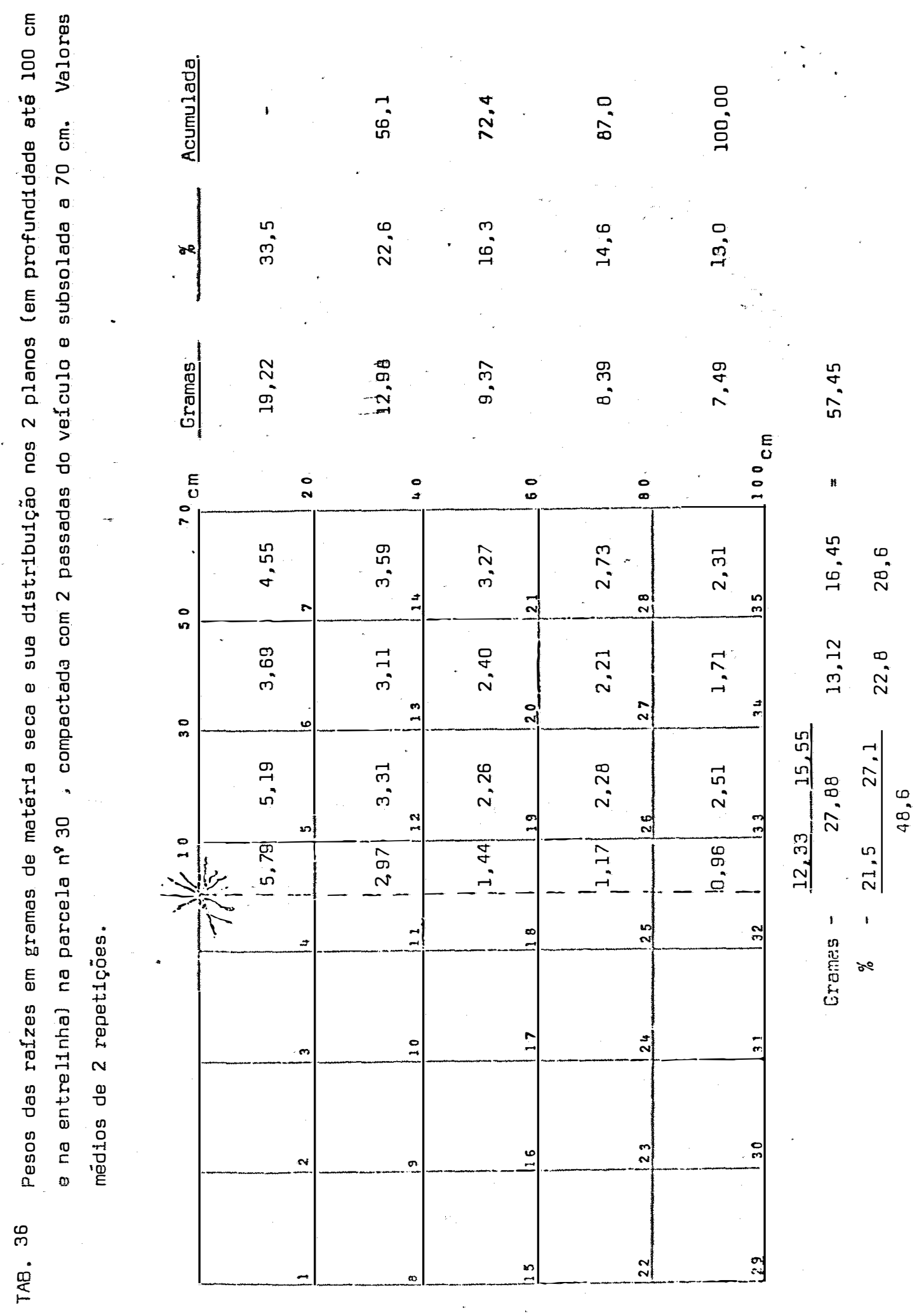




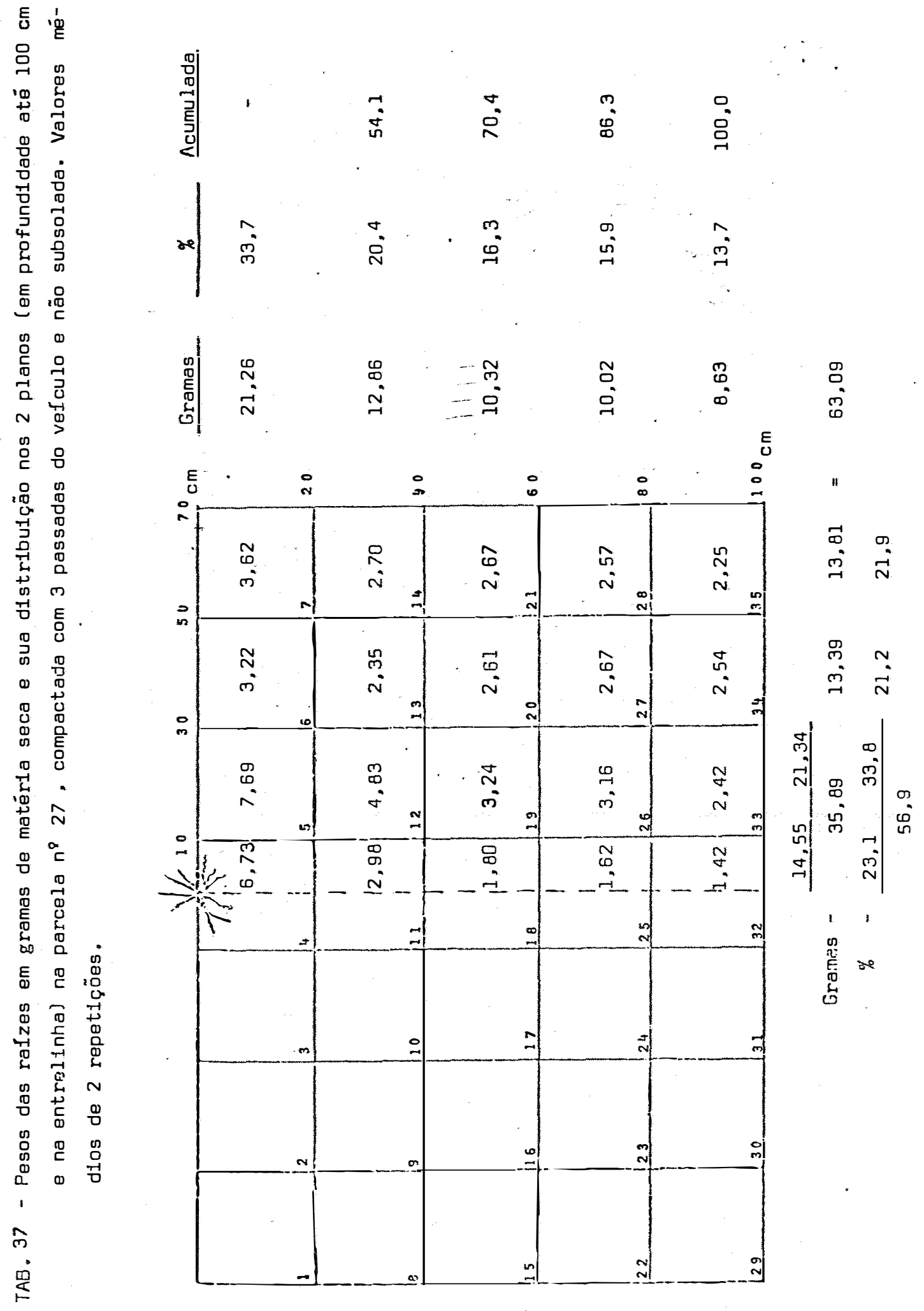




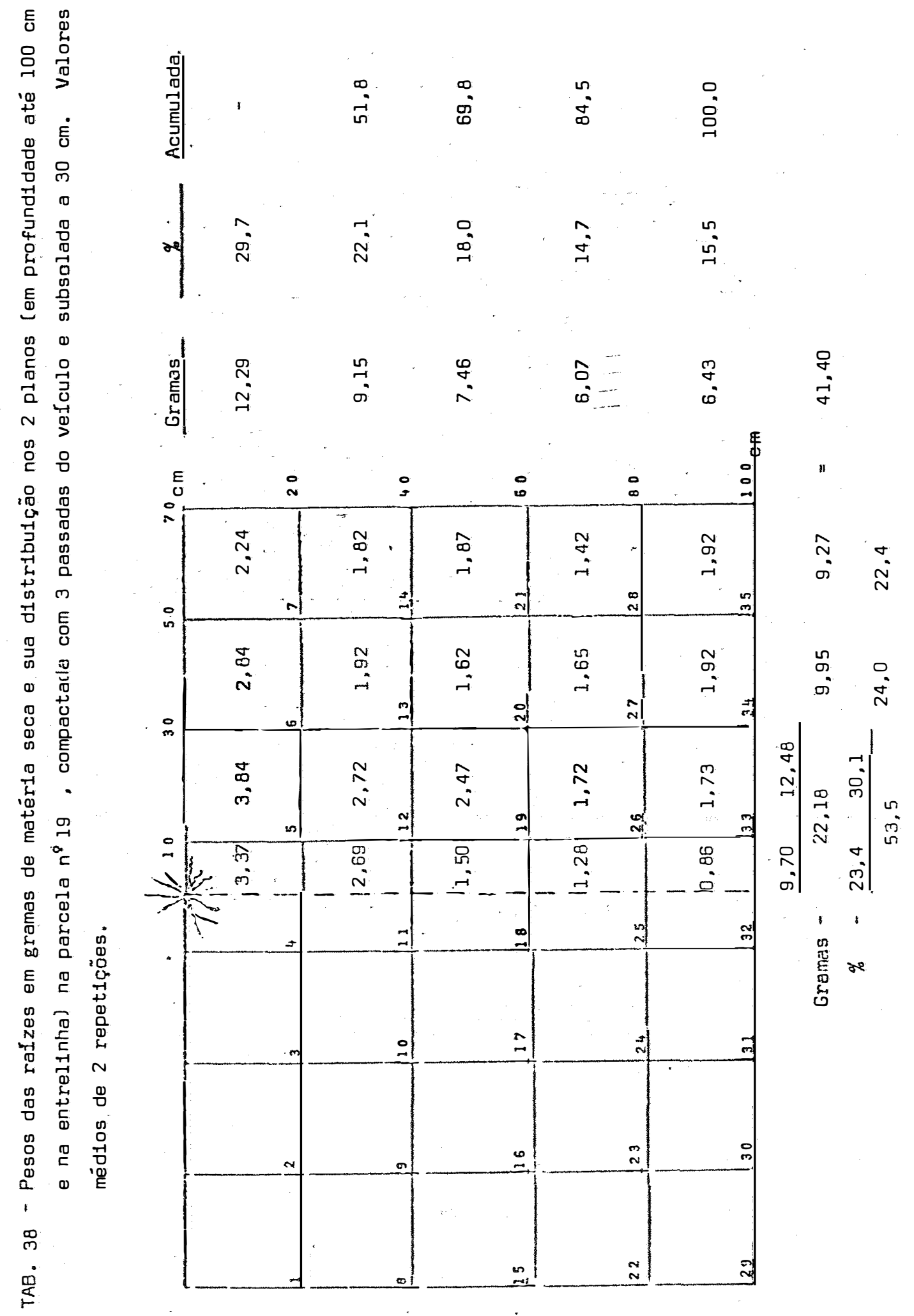




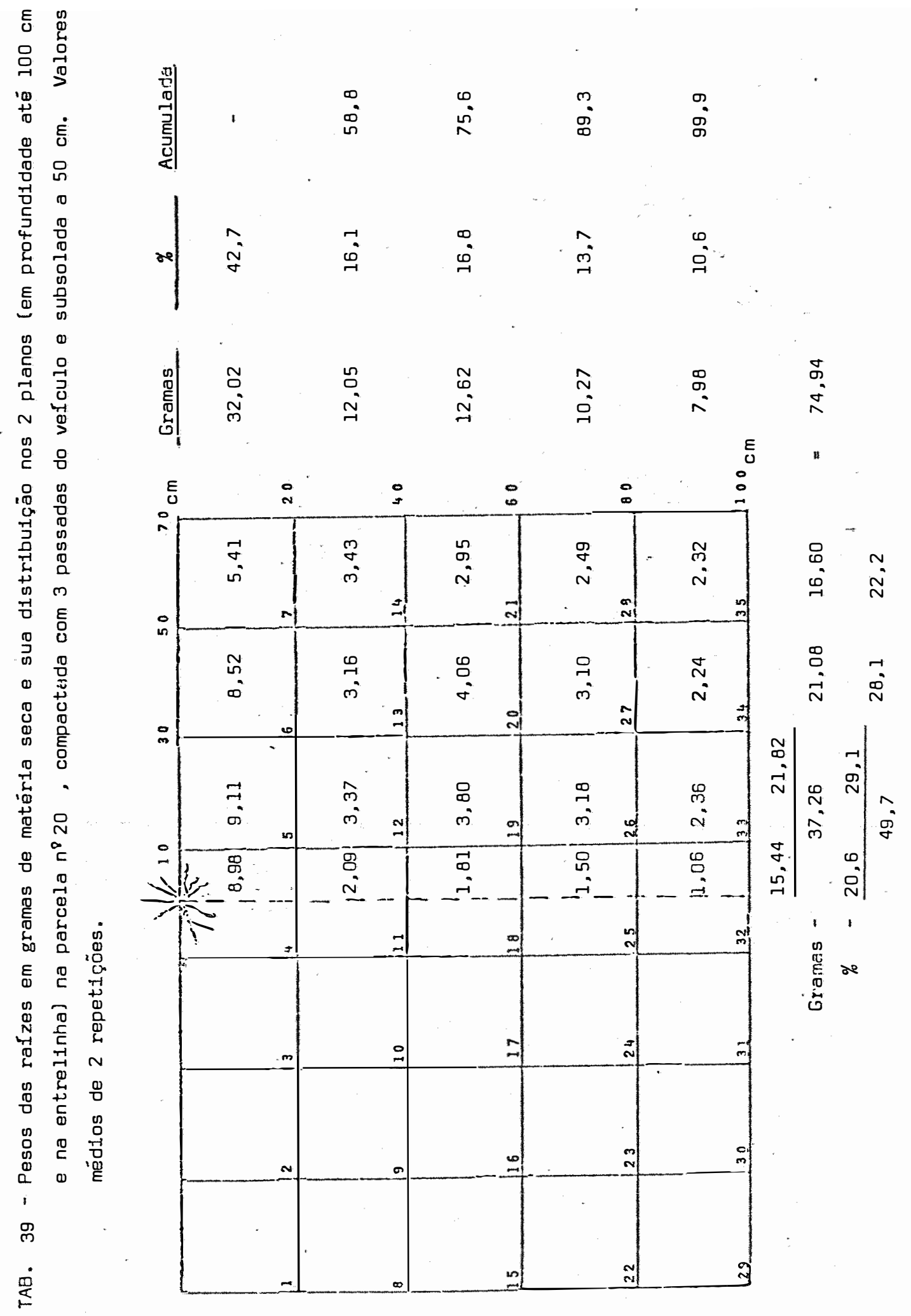




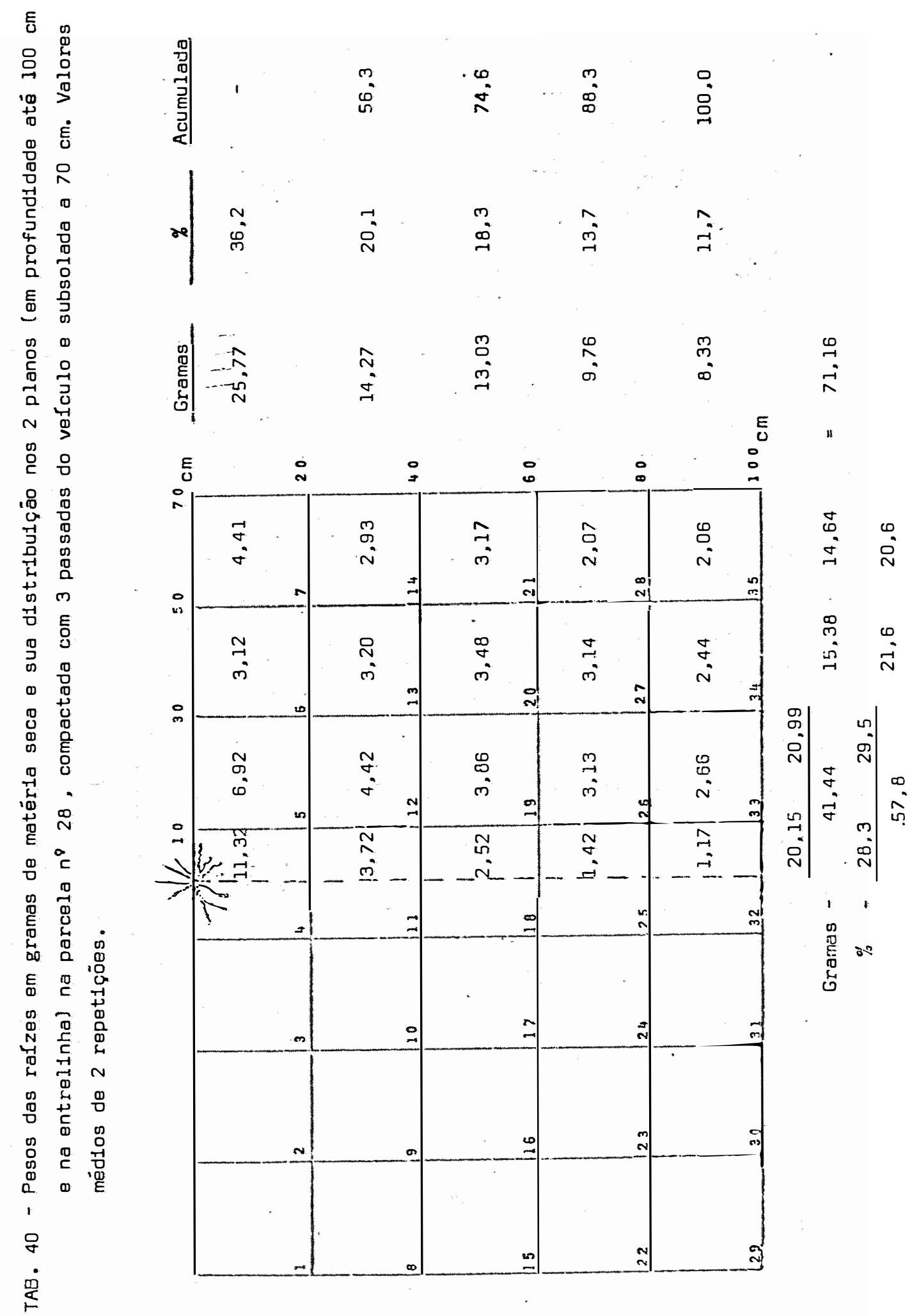


TABELA 41 - Quantidade de raiz, em peso de matéria seca, contida na amostra.

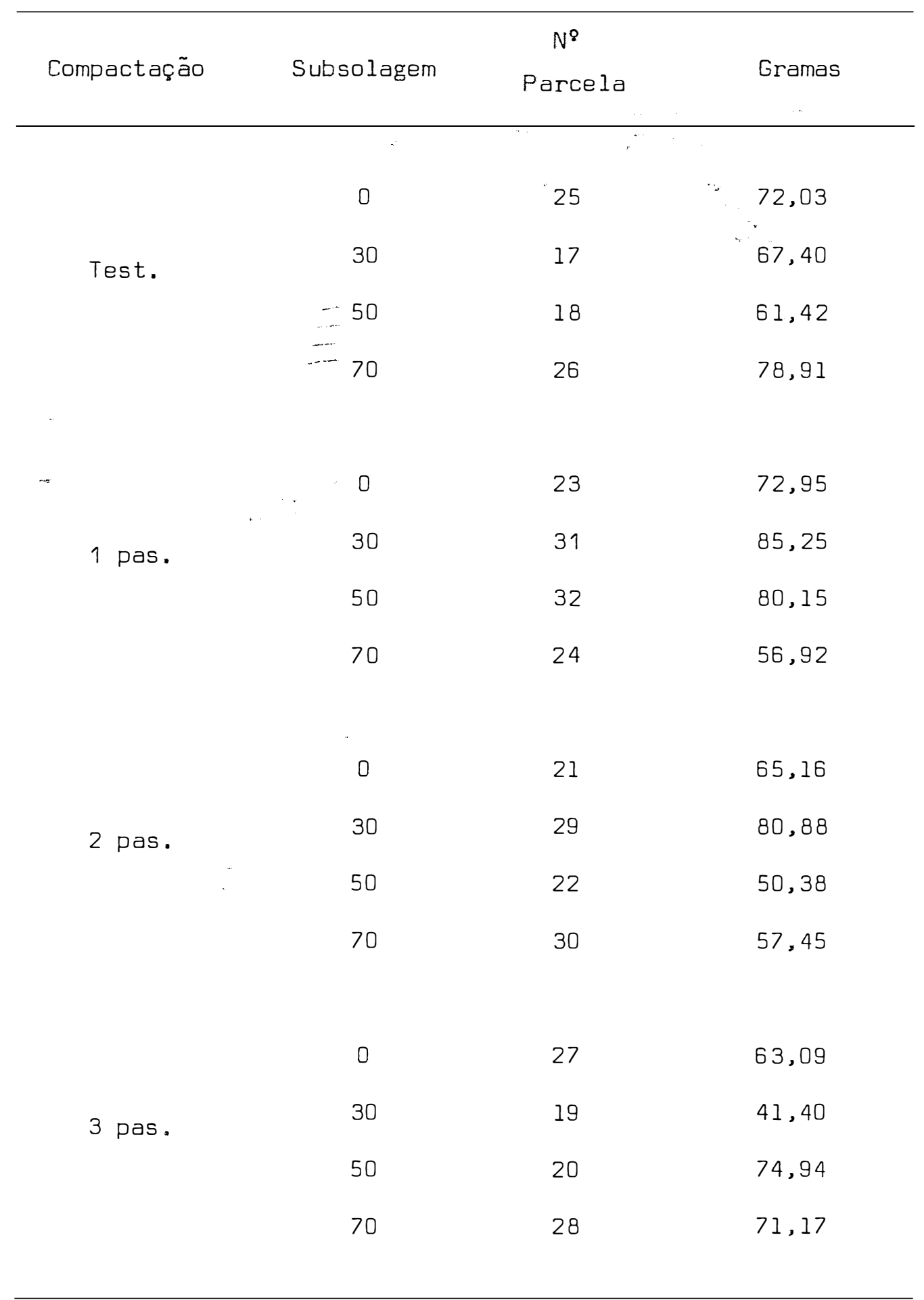



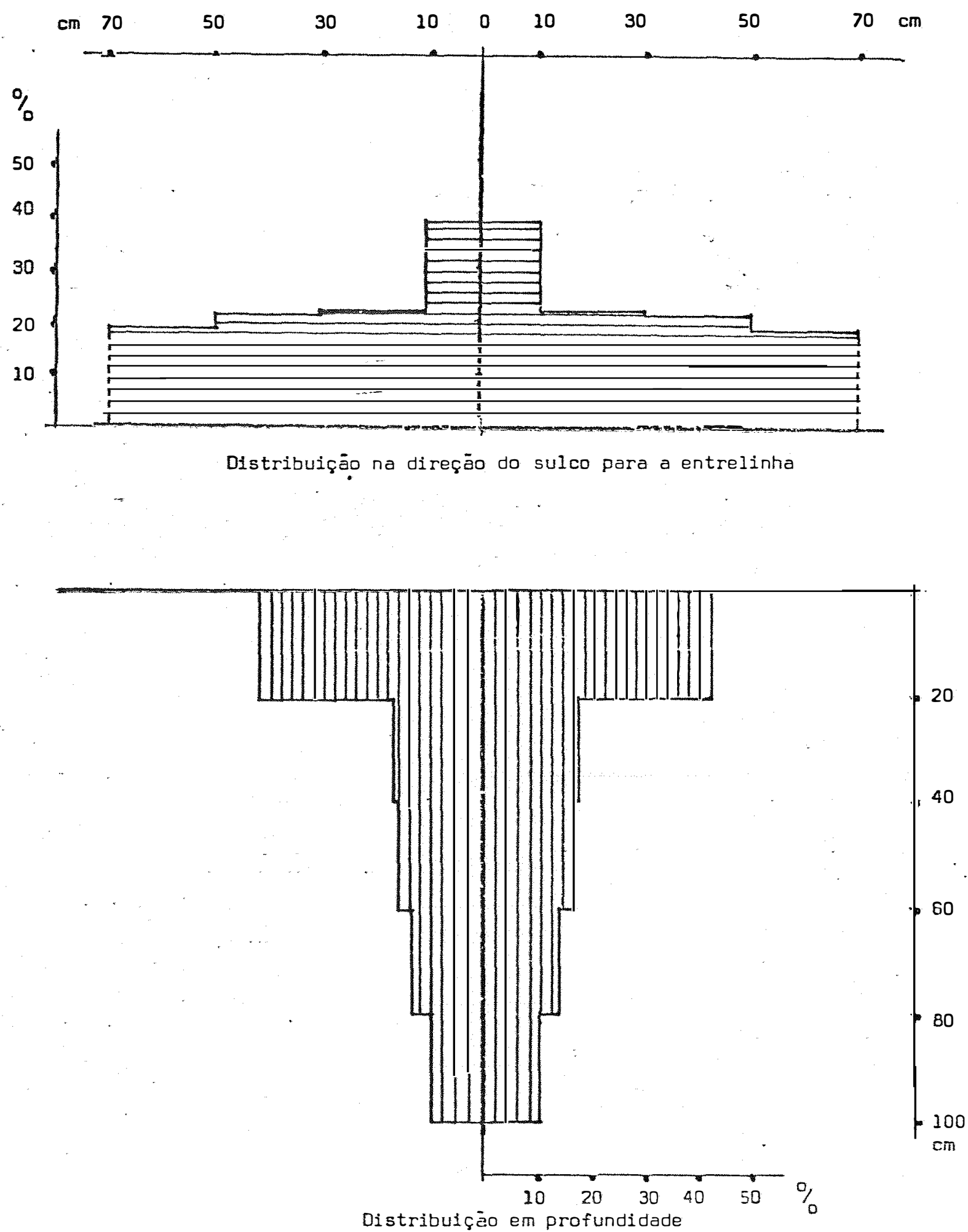

FIG. 30 - Distribuição porcentual do sistẹa radicular da cana-de-açúcar nos 2 sen tidos (em profundidade e na direção do sulco para a entrelinha), na parcela $n^{2} 25$, nāo compactada e não subsolada. 

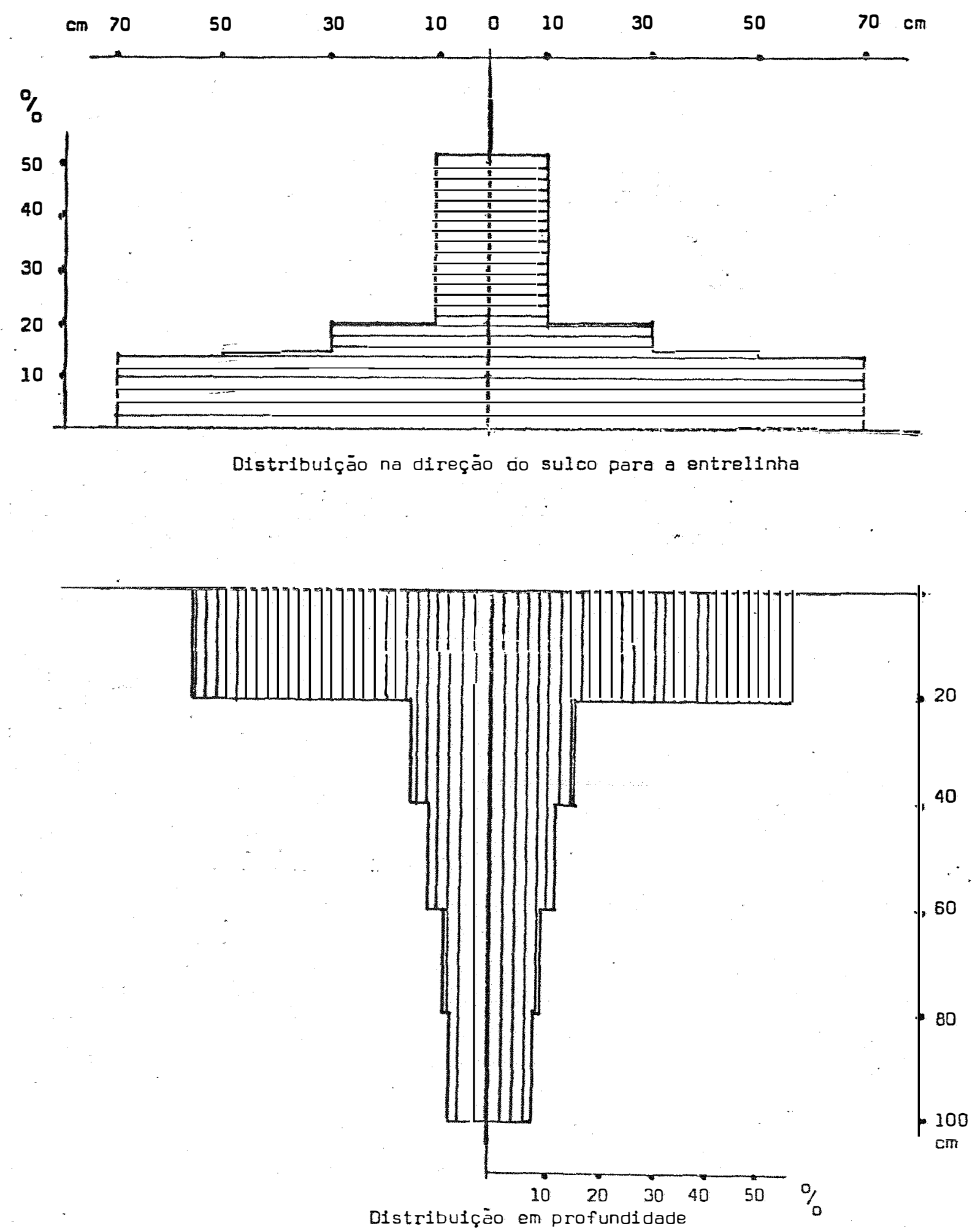

FIG. 31 - Distribuição porcentual do sistema radicular da cana-de-açücar nos 2 sen tidos (em profundidade e na direçào do sulco para a entrelinha), na parcela $n^{8} \mathbf{1 7}$, nào compactada e subsolada a $30 \mathrm{~cm}$. 

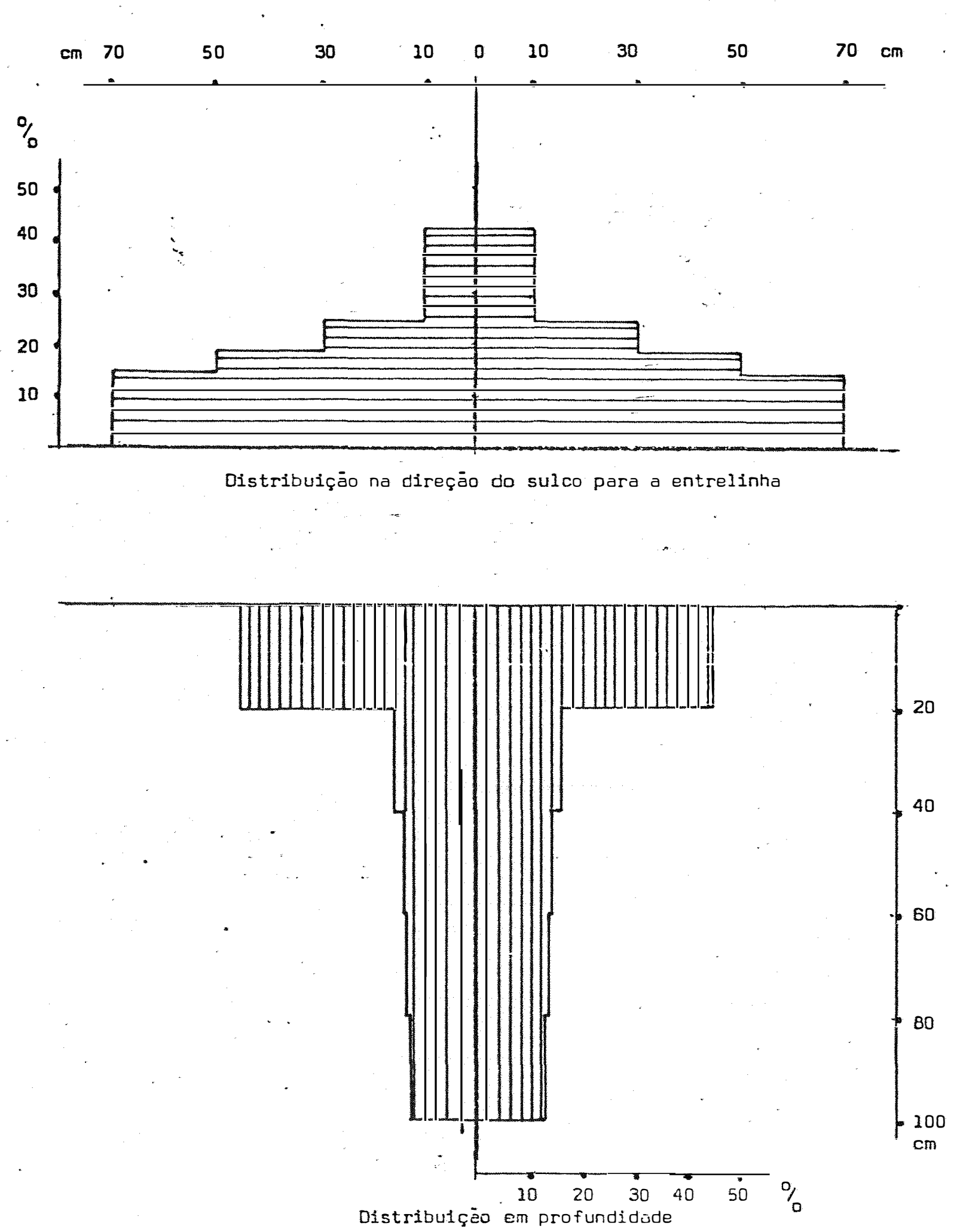

FIG. 32 - Distribuição porcentual do sistema radicular da cana-de-açūcar nos 2 sen tidos (em profundidade e na direçāo do sulco para a entrelinha), na parcela $n^{8} 18$, nào compactada e subsolada a $50 \mathrm{~cm}$. 

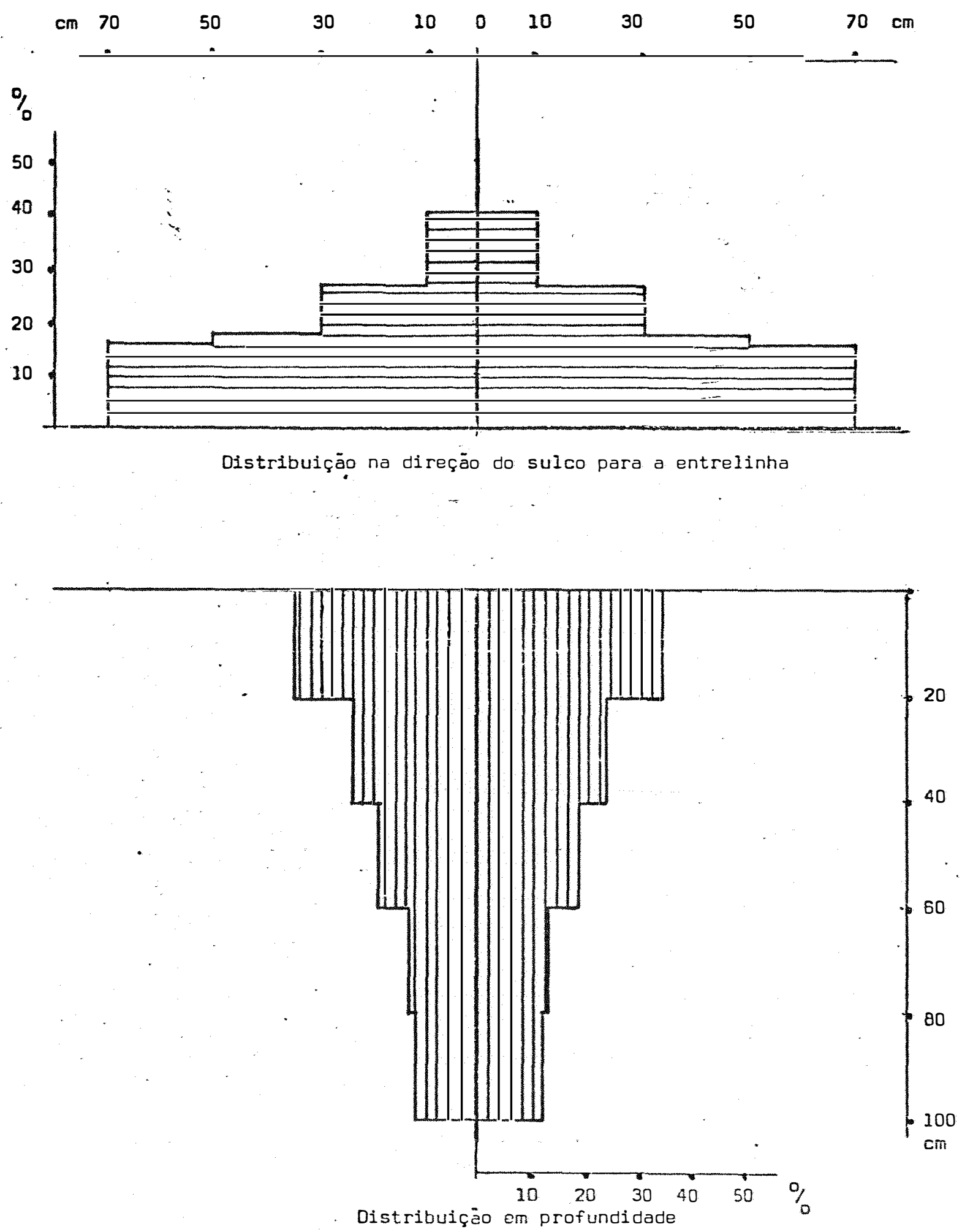

FIG. 33 - Distribuição porcentual do sistema radicular da cana-de-açúcar nos 2 sen tidos (em profundidade e na direçào do sulco para a entrelinha), na parcela $n^{2} 26$, não compactada e subsolada a $70 \mathrm{~cm}$. 


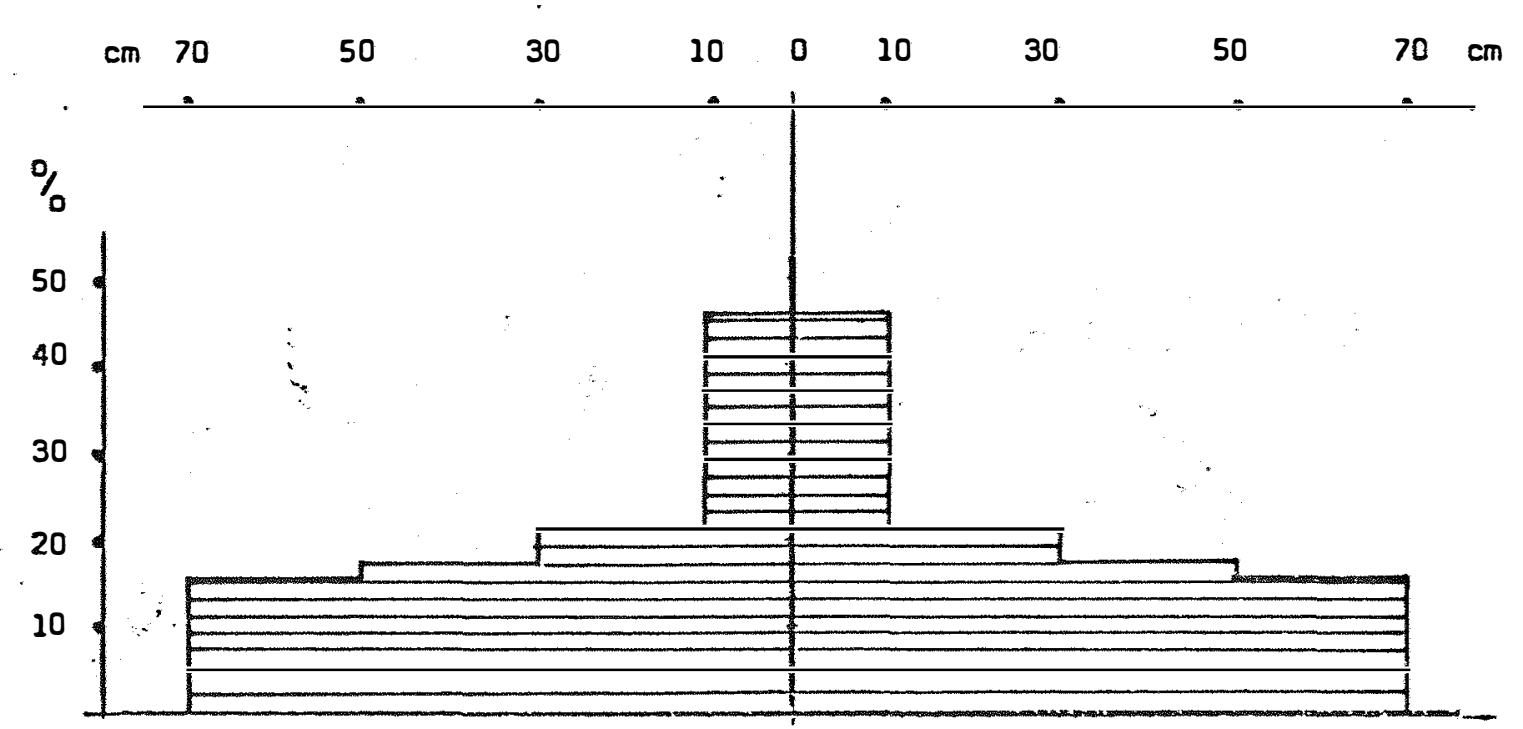

Distribuiçāo na direção do sulco para a entrelinha

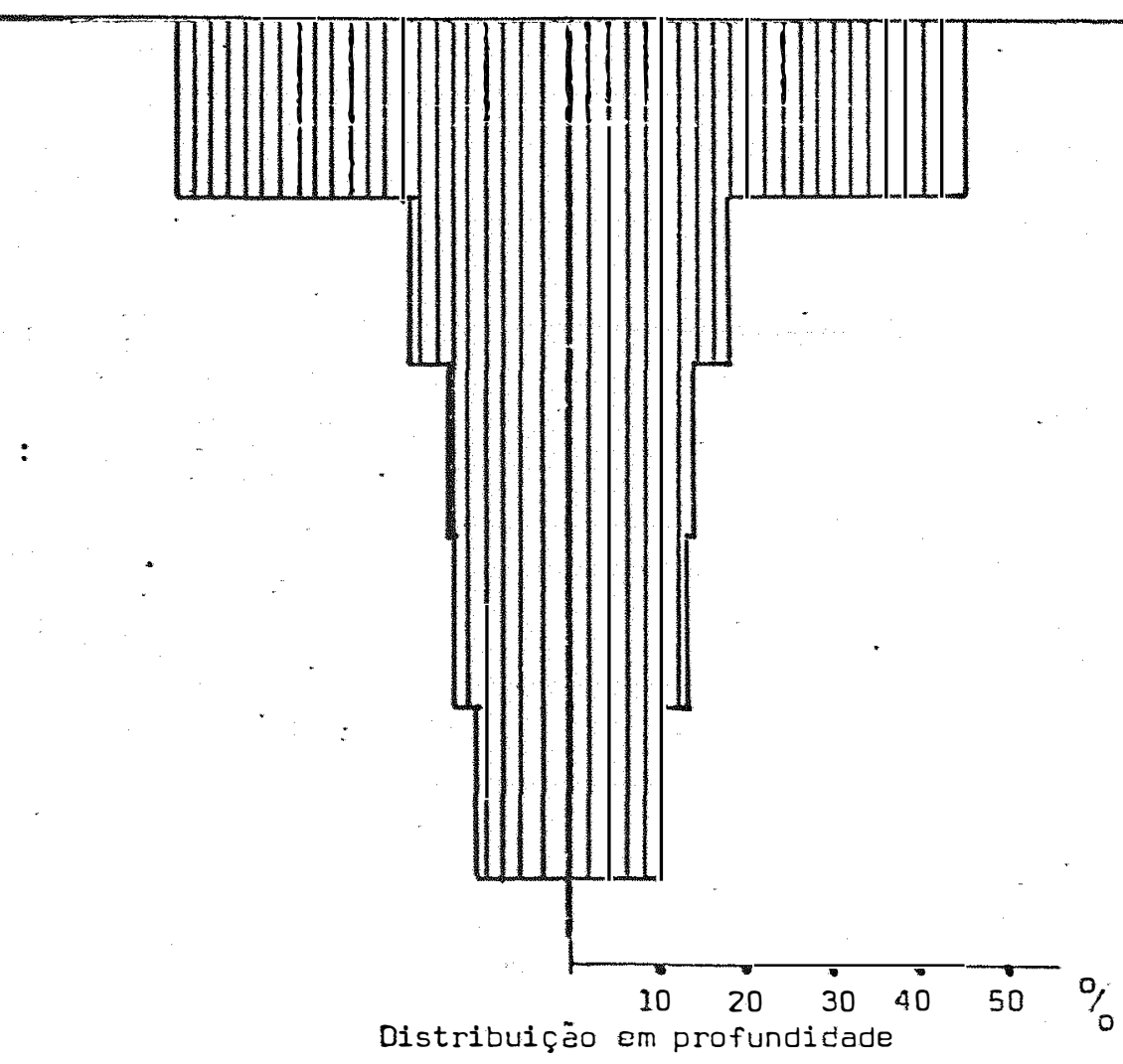

FIG. 34 - Distribuiçäo porcentual do sistema radicular da cana-de-açücar nos 2 sen tidos (em profundidade e na direçäo do sulco para a entrelinha), na parcela $n^{8}$ 23, compactada com 1 passada e não subsolada. 

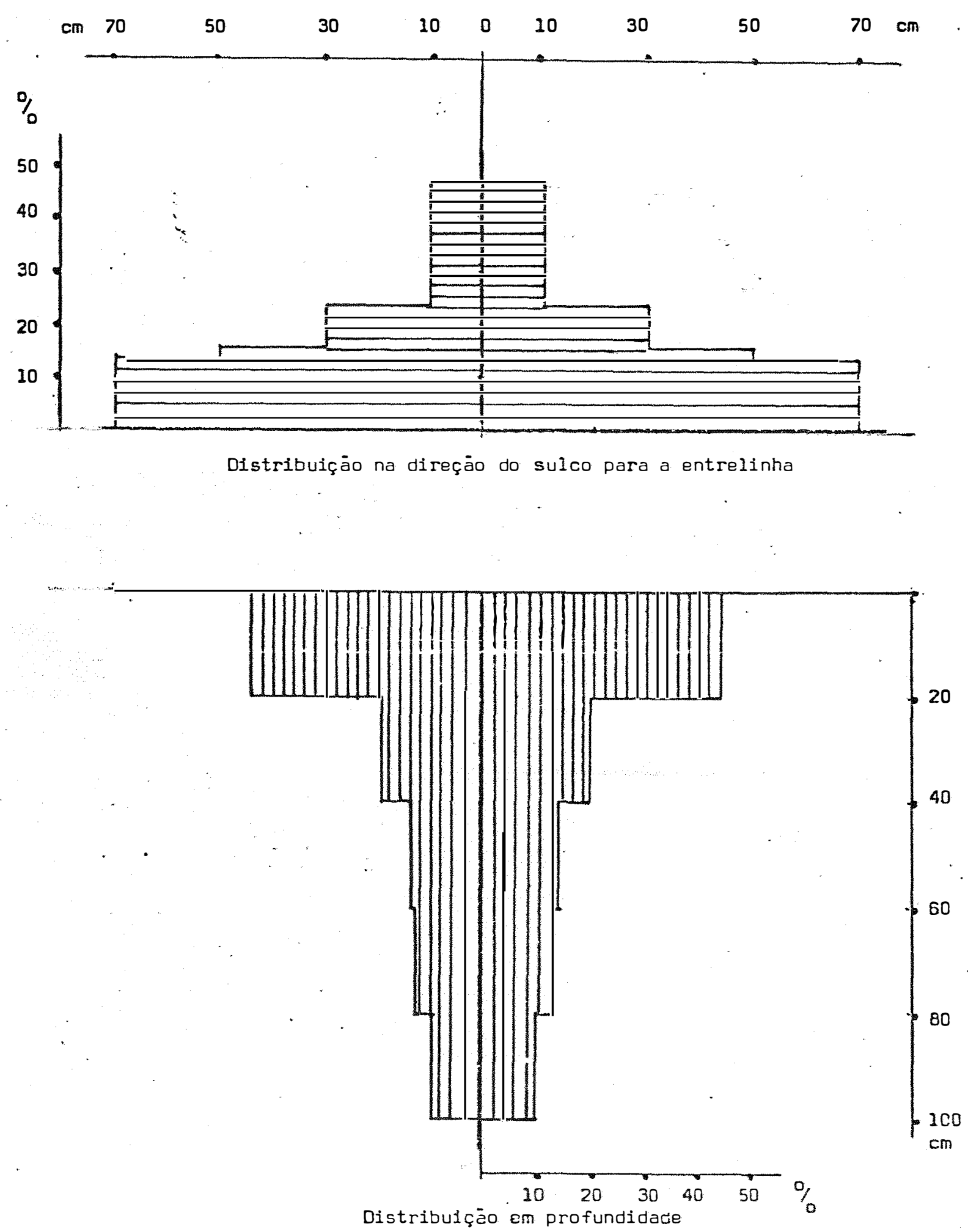

FIG. 35 - Distribuiçāo porcentual do sistema radicular da cana-de-açücar nos 2 sen tidos (emprofundidade e na direçào do sulco para a entrelinha), na parcela $n^{2} 31$. compactada com 1 passada e subsolada a $30 \mathrm{~cm}$. 

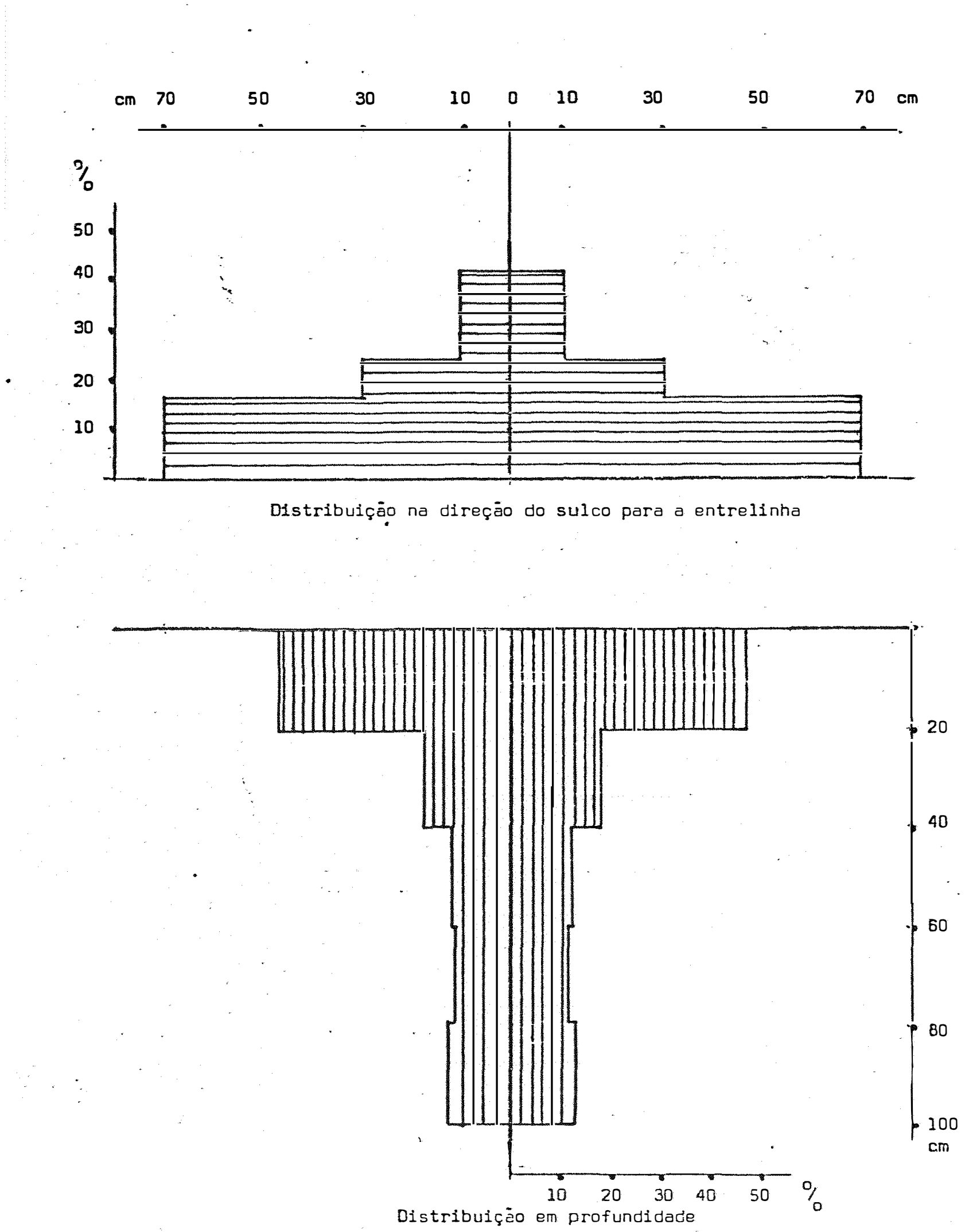

FIG. 36 - Distribuiçāo porcentual do sistema radicular da cana-de-açúcar nos 2 sen tidos (em profundidade e na direção do sulco para a entrelinha), na parcela $n^{8} 32$. compactada com 1 passada e subsolada a $50 \mathrm{~cm}$. 

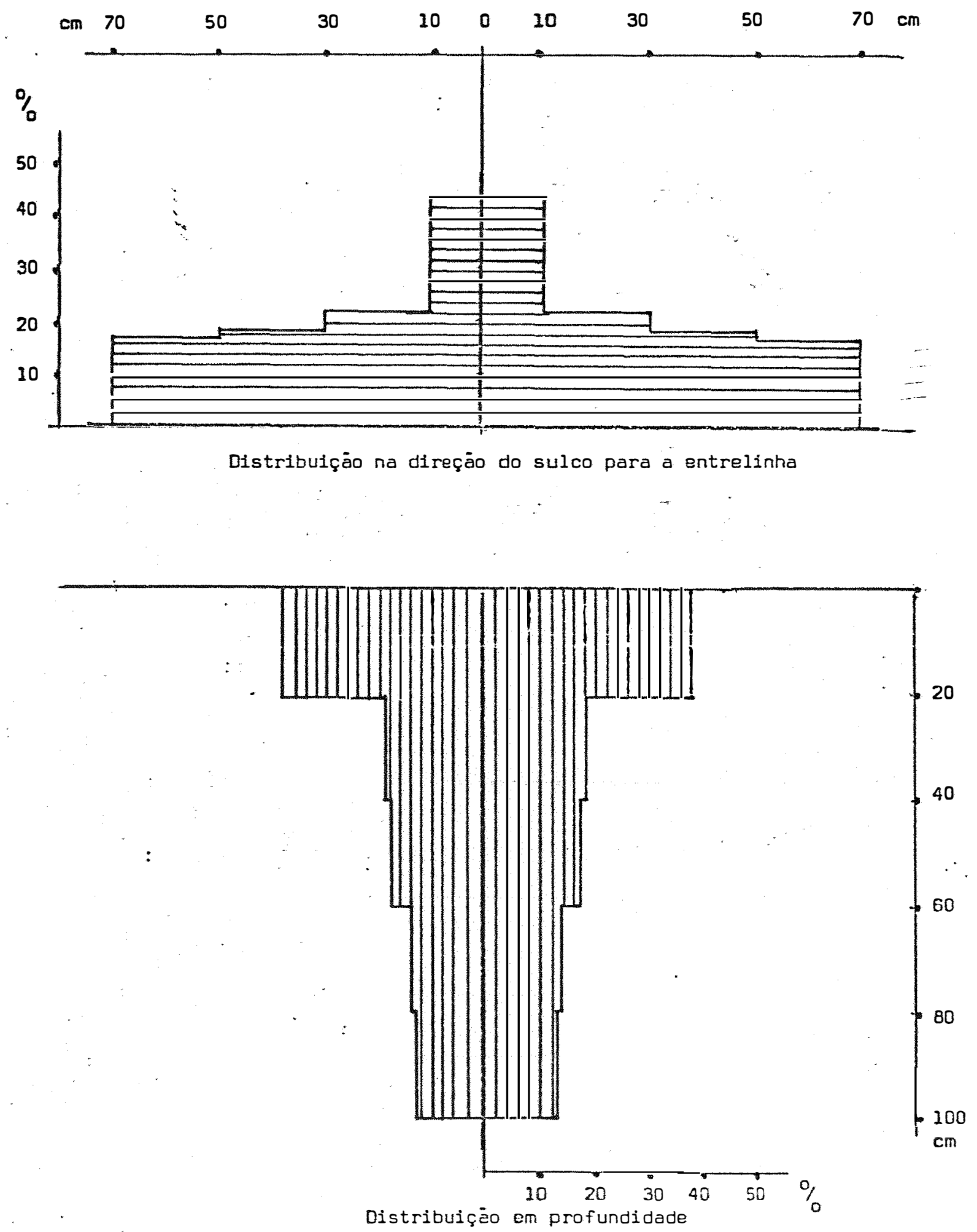

FIG. 37 - Distribuição porcentual do sistema radicular da cana-de-açúcar nos 2 sen t1dos (em profundidade e na direção do sulco para a entrelinha), na parcela $n^{8} 24$, compactada com 1 passada e subsolada a $70 \mathrm{~cm}$. 

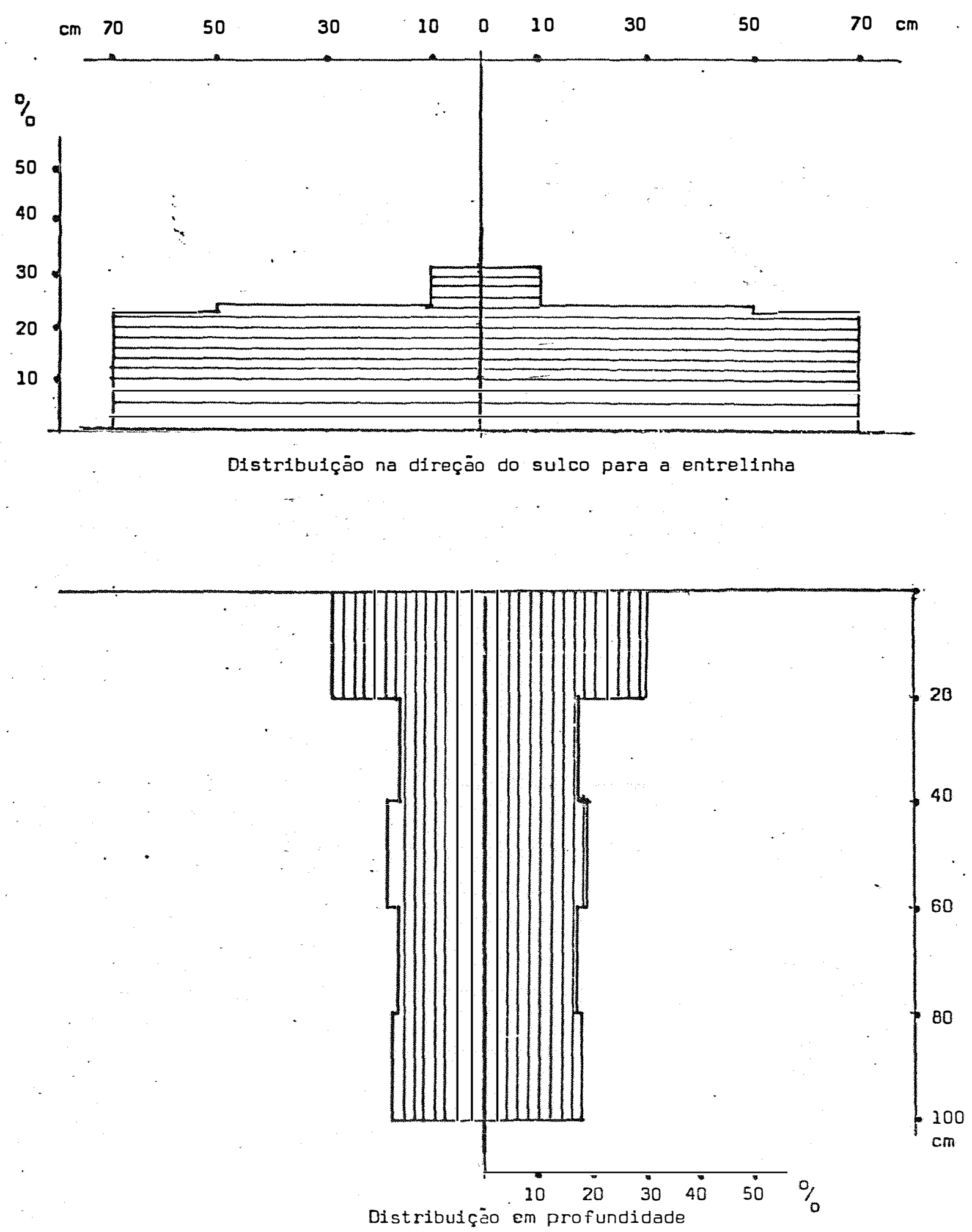

FIG. 38- Distribuiçào porcentual do sisteną radicular da cana-de-açücar nos 2 sen tidos (em profundidade e na direçào do sulco para a entrelinha), na parcela $n^{\circ} 21$. compactada com 2 passadas-e nào subsolada. 


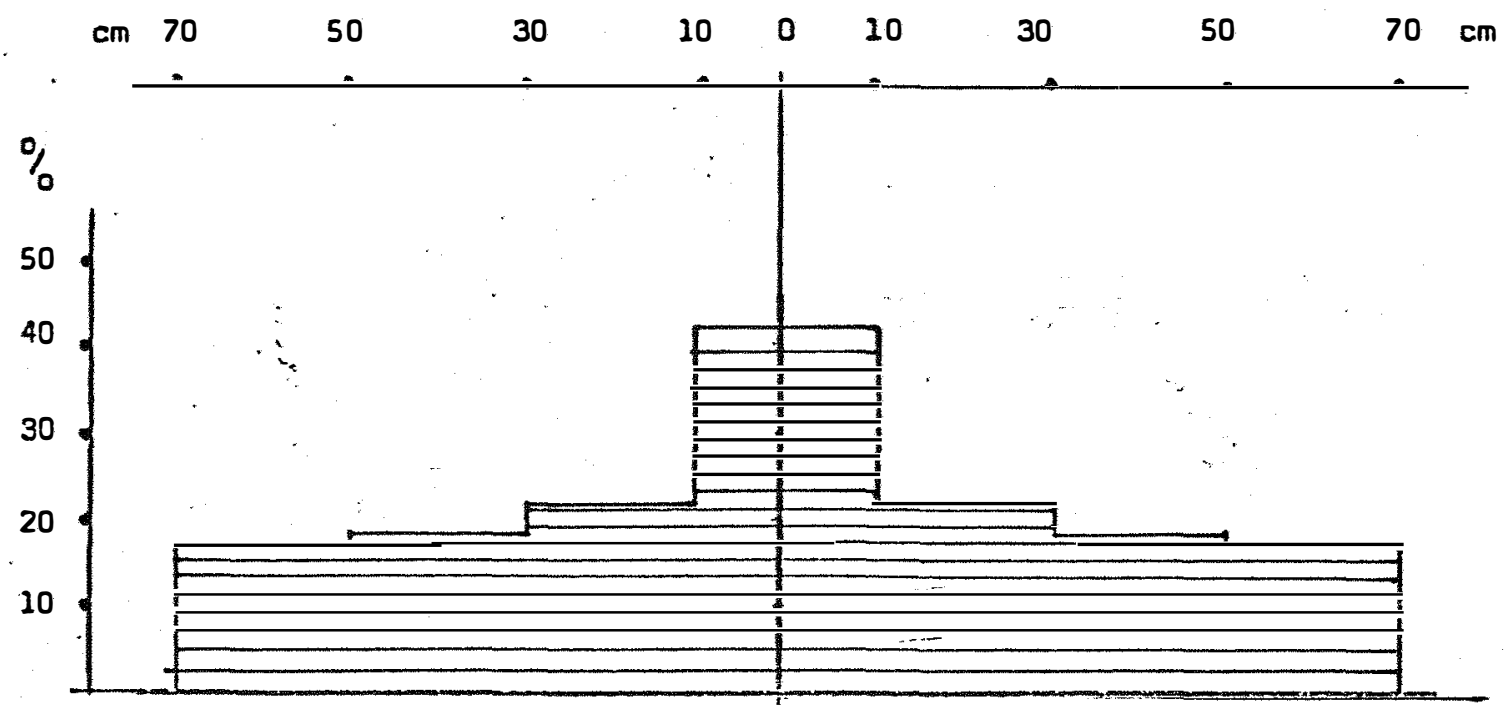

Distribuiçāo na direçāo do sulco para a entrelinha $\because$

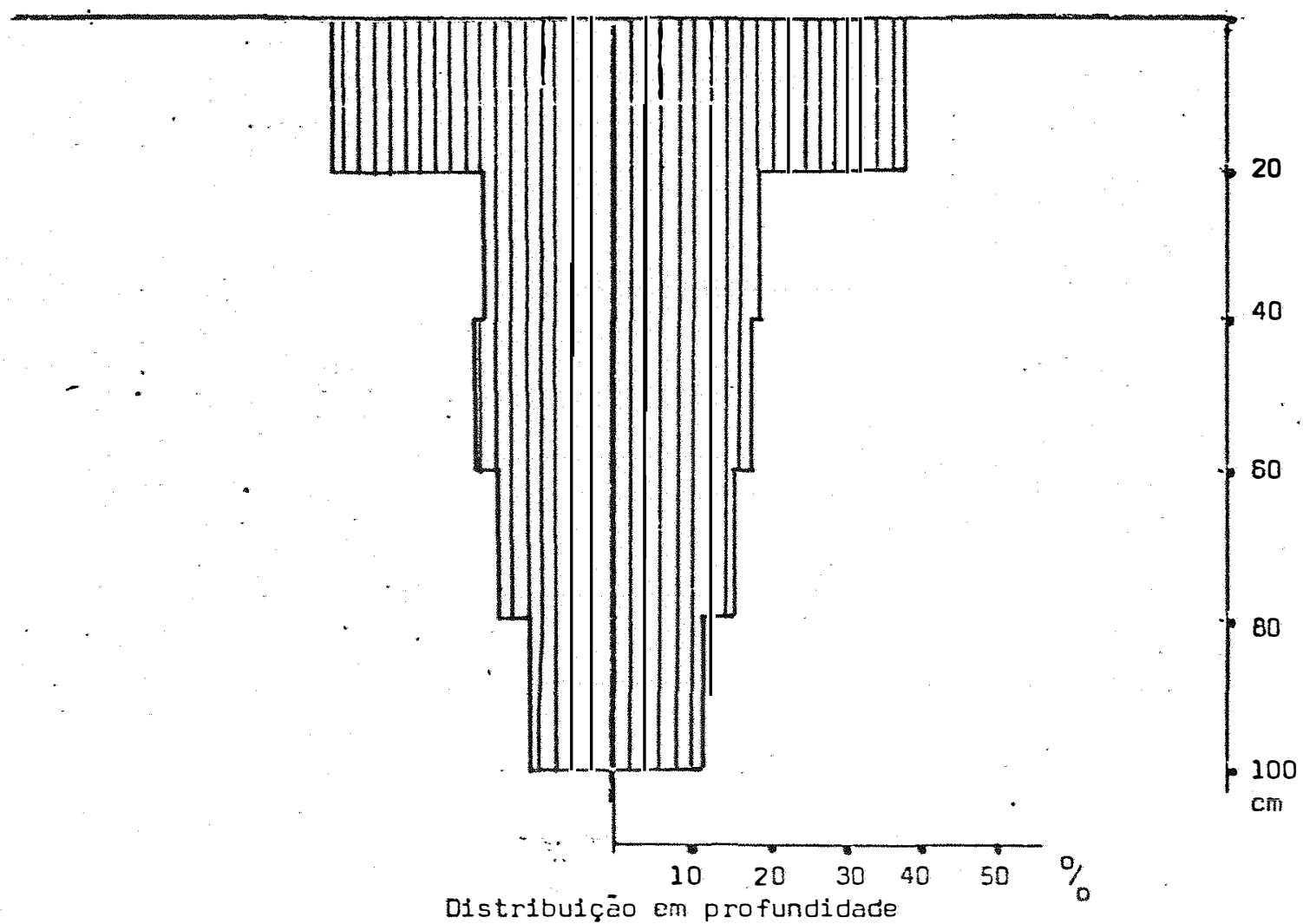

FIG. 39 - Distribuição porcentual do sistema radicular da cana-de-açücar nos 2 sen tidos (em profundidade e na direção do sulco para a entrelinha), na parcela $n^{8} 29$, compactada com 2 passadas e subsolada a $30 \mathrm{~cm}$. 


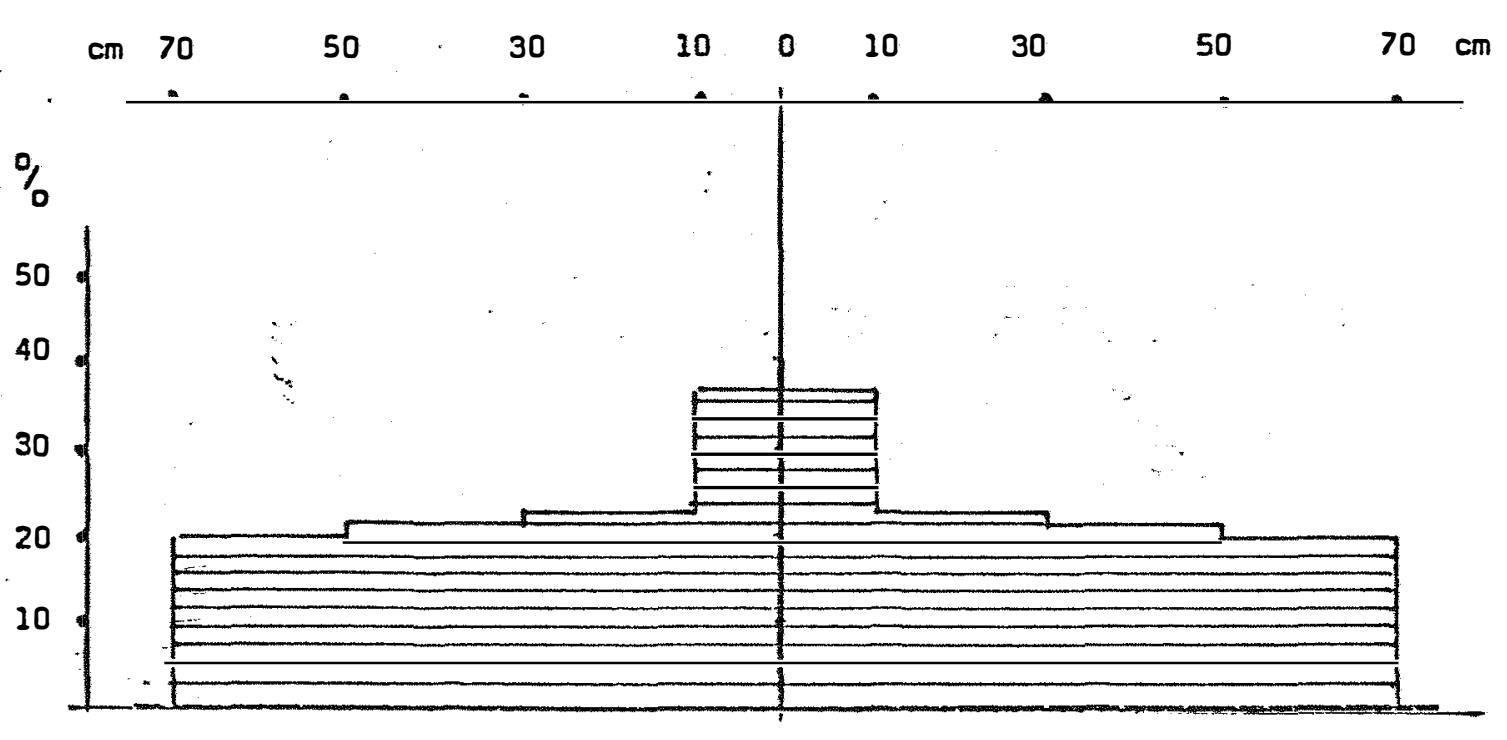

Distribuiçāo na direçāo do sulco para a entrelinha

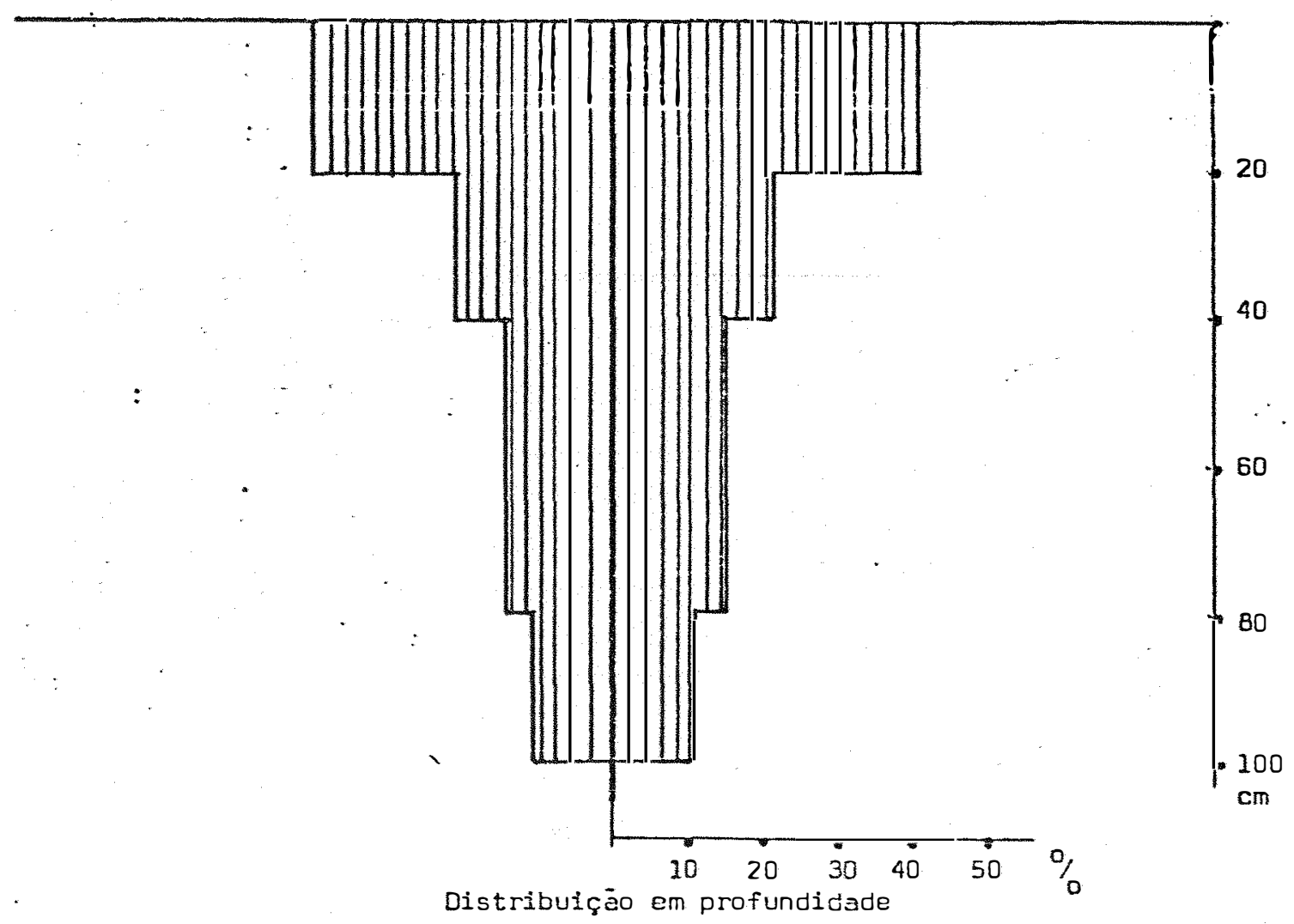

FIG. 40 - Distribuição porcentual do sistema radicular da cana-de-açūcar nos 2 sen tidos (em profundidade e na direçāo do sulco para a entrelinha), na parcela $n^{2} 22$. compactada com 2 passadas e subsolada a $50 \mathrm{~cm}$. 


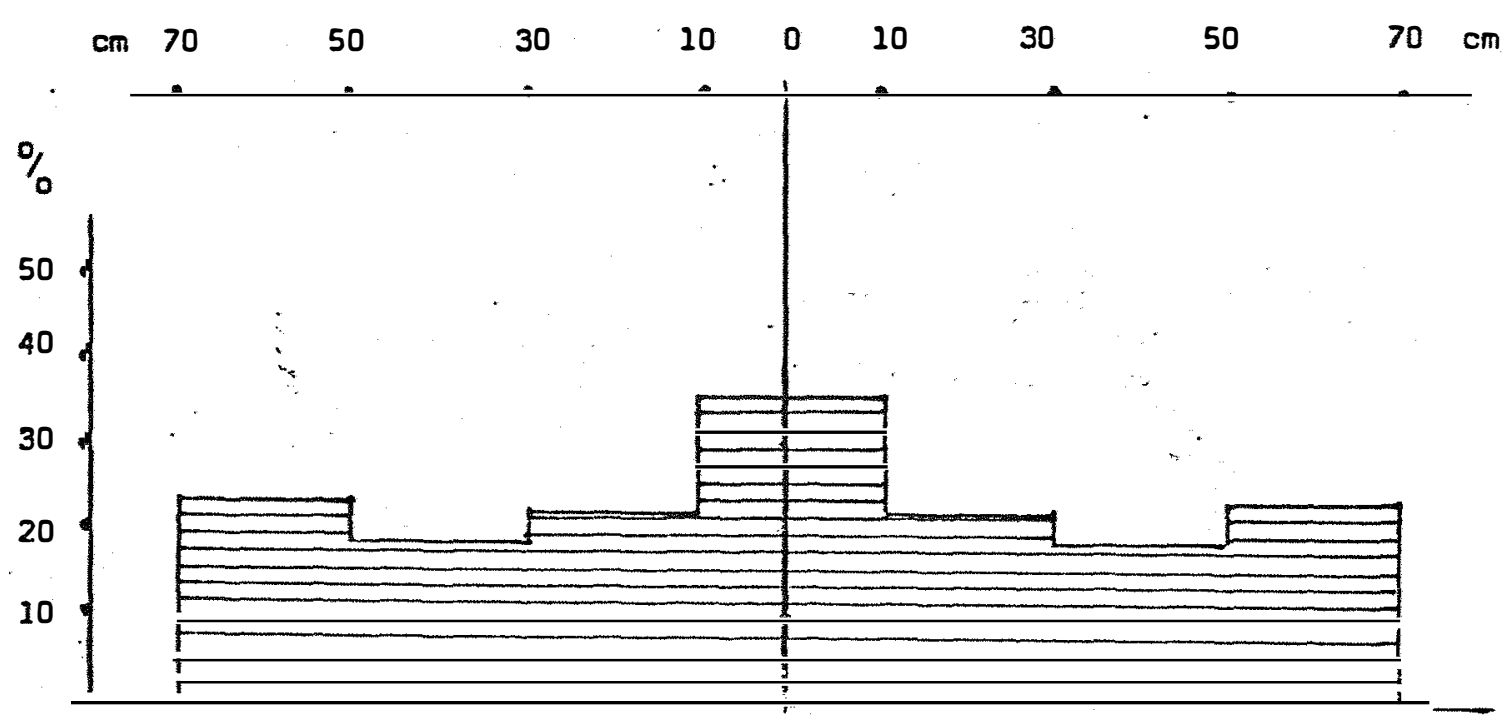

Distribuição na direção do sulco para a entrelinha

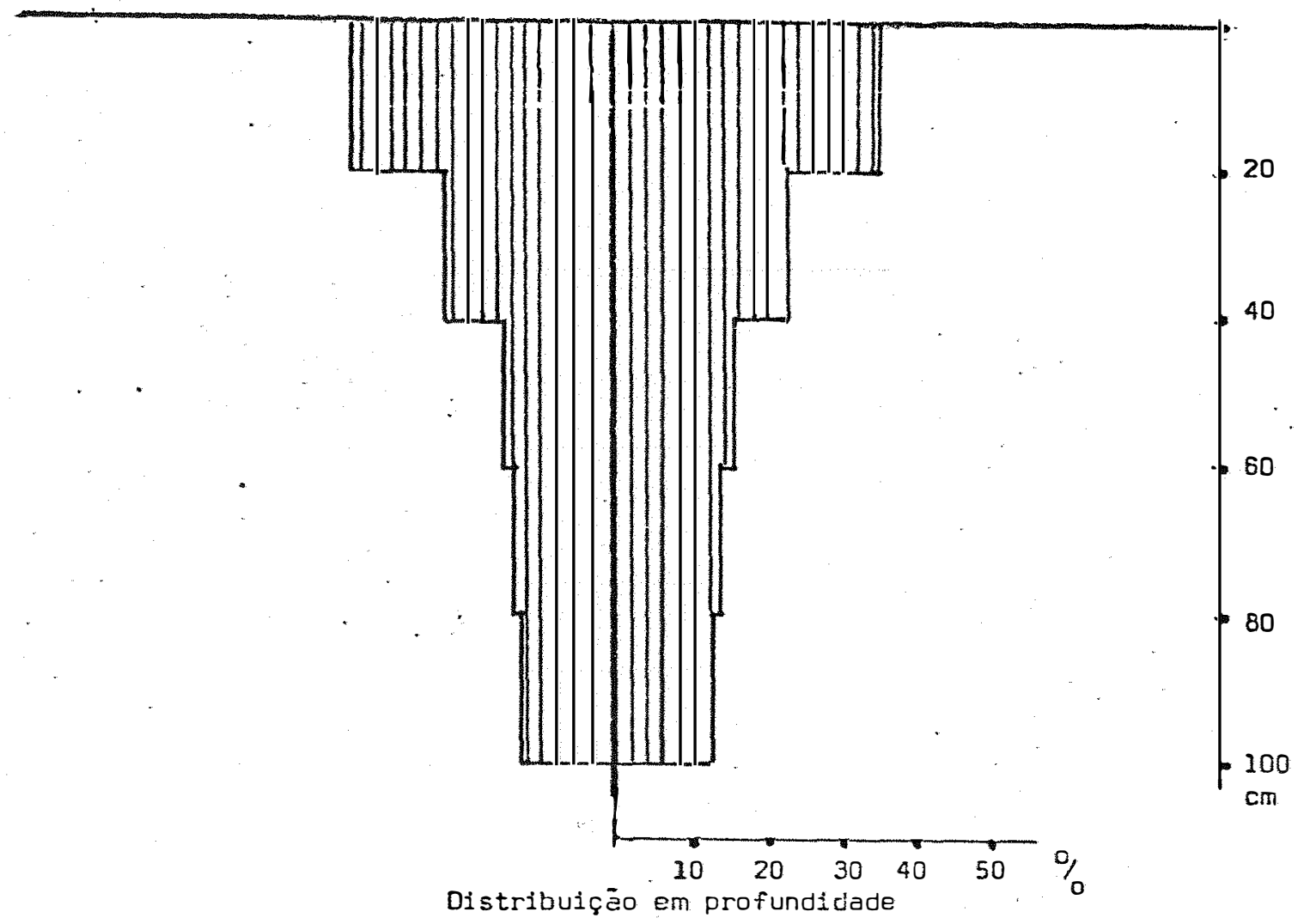

FIG. 41 - Distribuição porcentual do sistema radicular da cana-de-açúcar nos 2 sen tidos (em profundidade e na direçāo do sulco para a entrelinha), na parcela $n^{8} 30$, compactada com 2 passadas e subsolada a $70 \mathrm{~cm}$. 

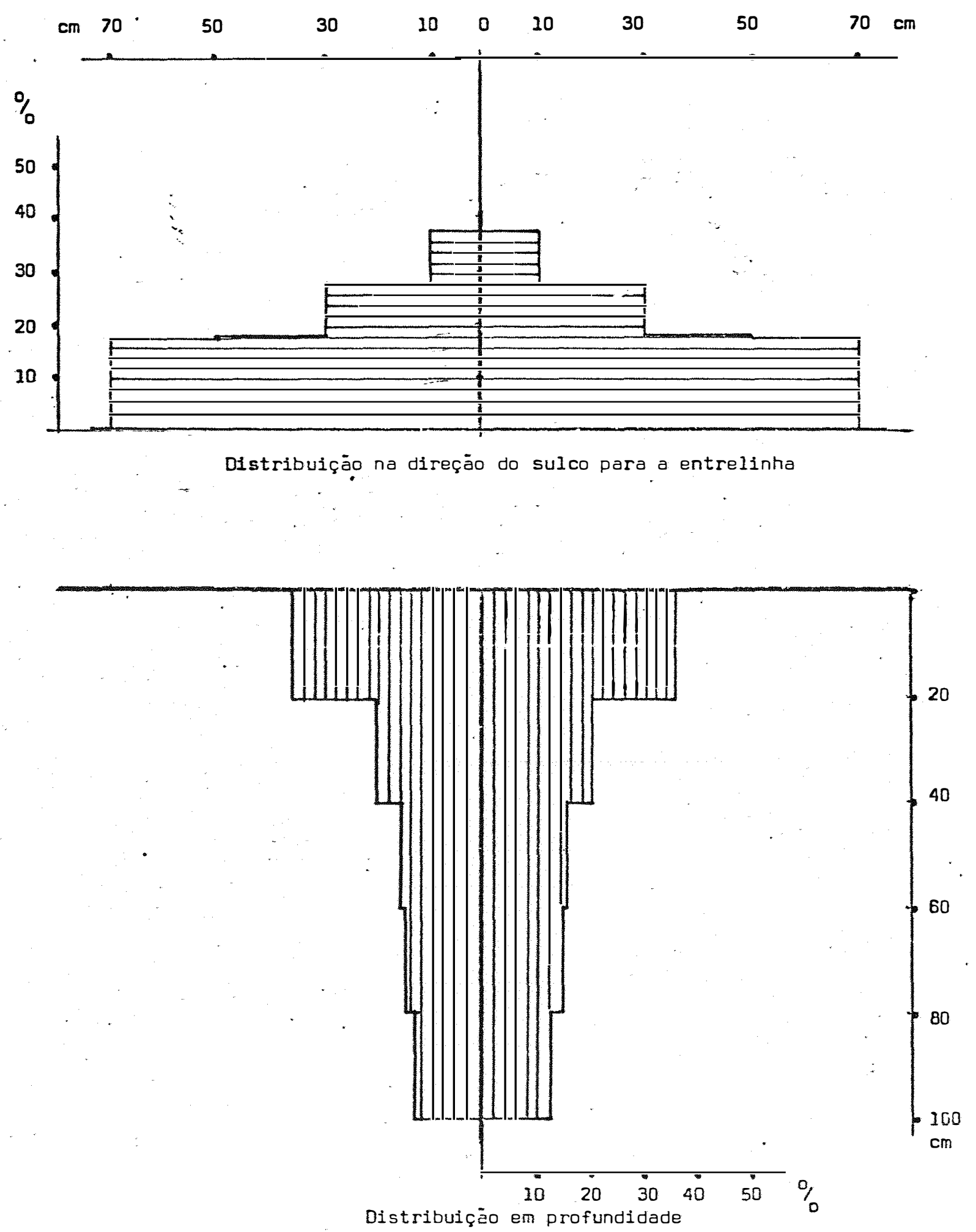

FIG. 42 - Distribuiçäo porcentual do sistema radicular da cana-de-açúcar nos 2 sen tidos (em profundidade e na direção do sulco para a entrelinha), na parcela $n^{9} 27$, compactada com 3 passadas a nào subsolada. 


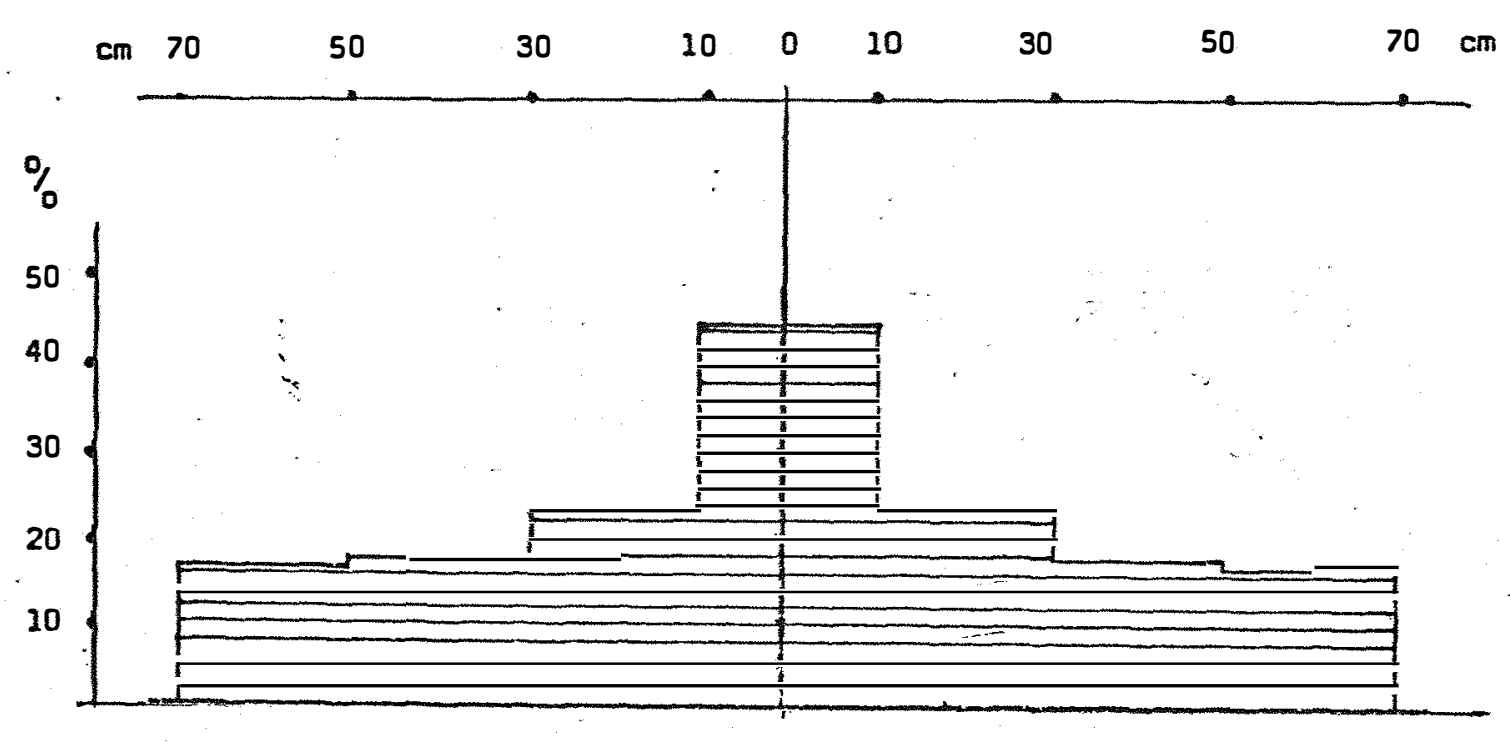

Distribuiçāo na direçāo do sulco para a entrelinha

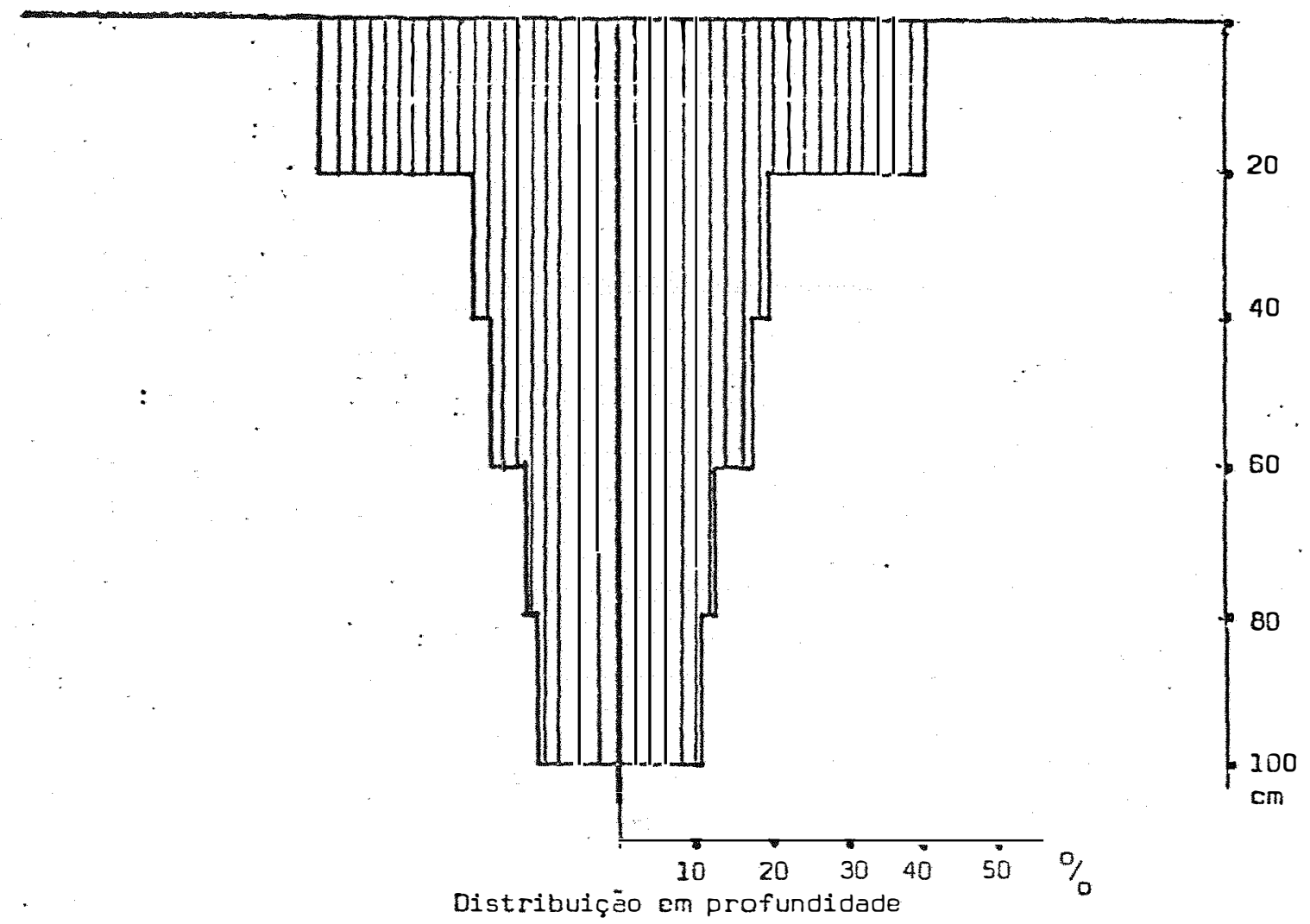

FIG. 43 - Distribuiçäo porcentual do sistema radicular da cana-de-açücar nos 2 sen tidos(em profundidade $\varepsilon$ na direçào do sulco para a entrelinhal, na parcela $n^{8} 19$, compactada com 3 passadas e subsólada a $30 \mathrm{~cm}$. 

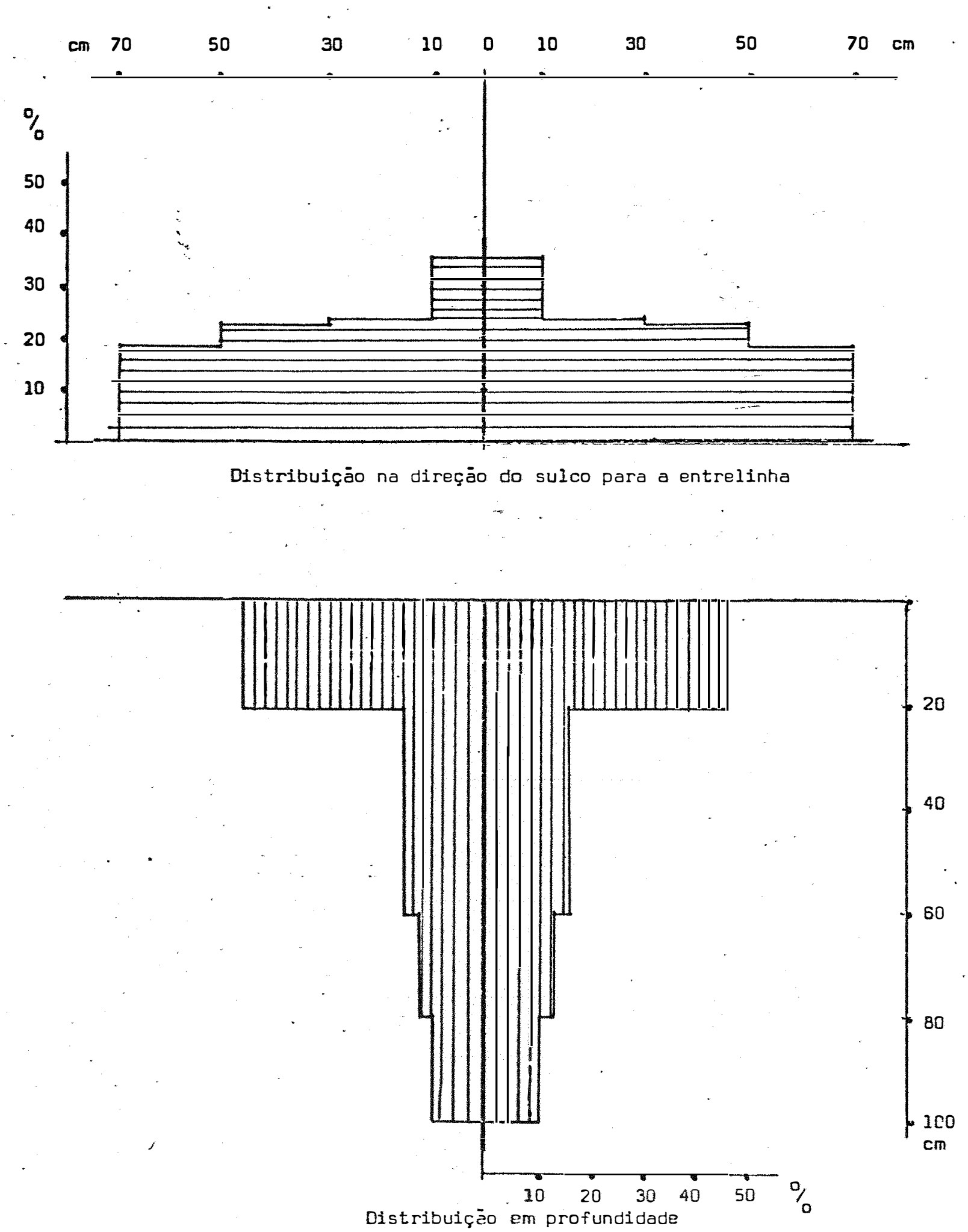

FIG. 44 - Distribuiçào porcentual do sistema radicular da cana-de-açúcar nos 2 sen tidos (em profundidade e na direçào do sulco para a entrelinha), na parcela $n^{8} 20$, compactada com 3 passadas e subsolada a $50 \mathrm{~cm}$. 

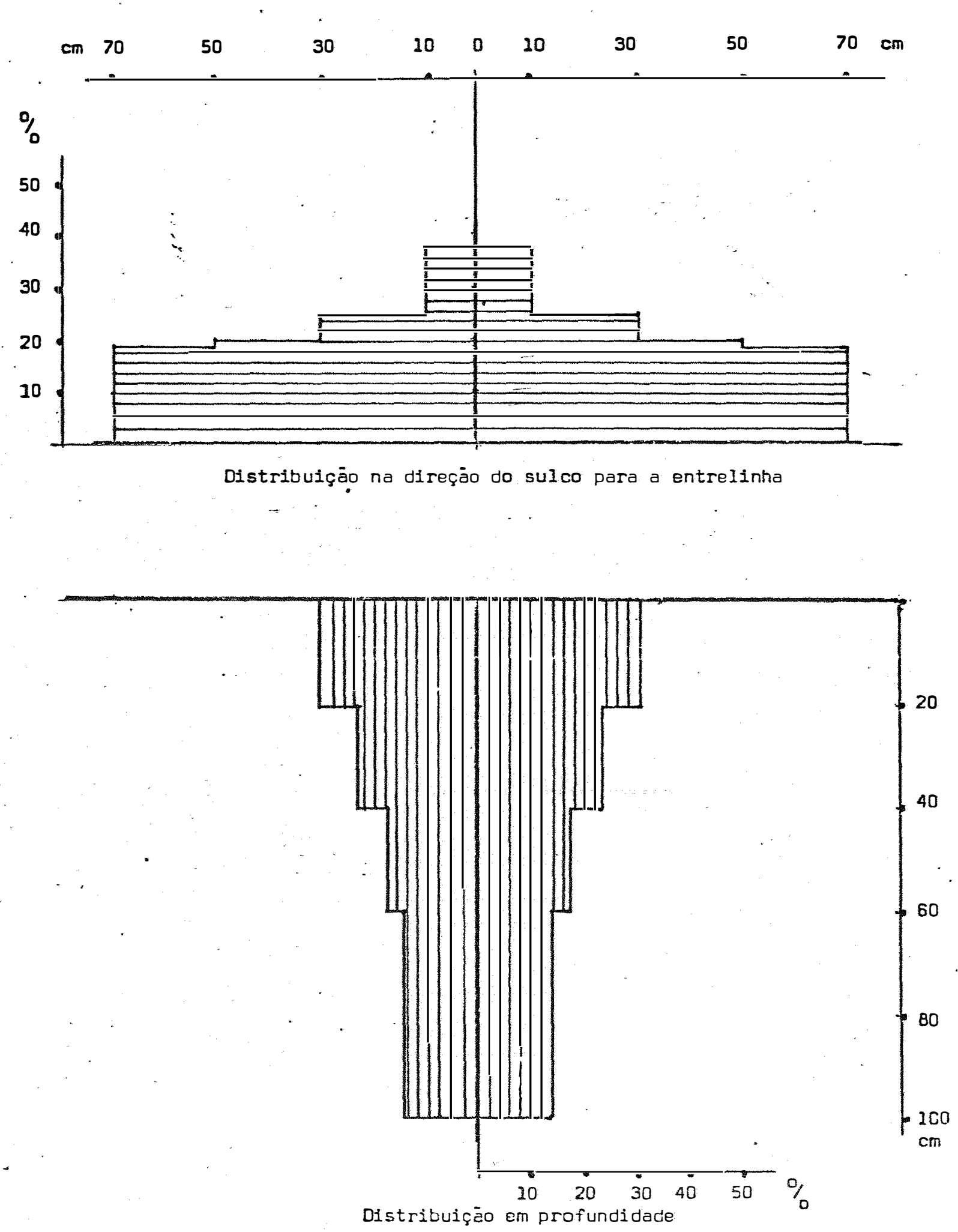

FIG. 45- Distribuiçào porcentual do sistema radicular da cana-de-açücar nos 2 sen tidos (em profundidade e na direção do sulco para a entrelinha), na pascela $n^{8} 28$, compactada com 3 passadas e subsolada a $70 \mathrm{~cm}$. 

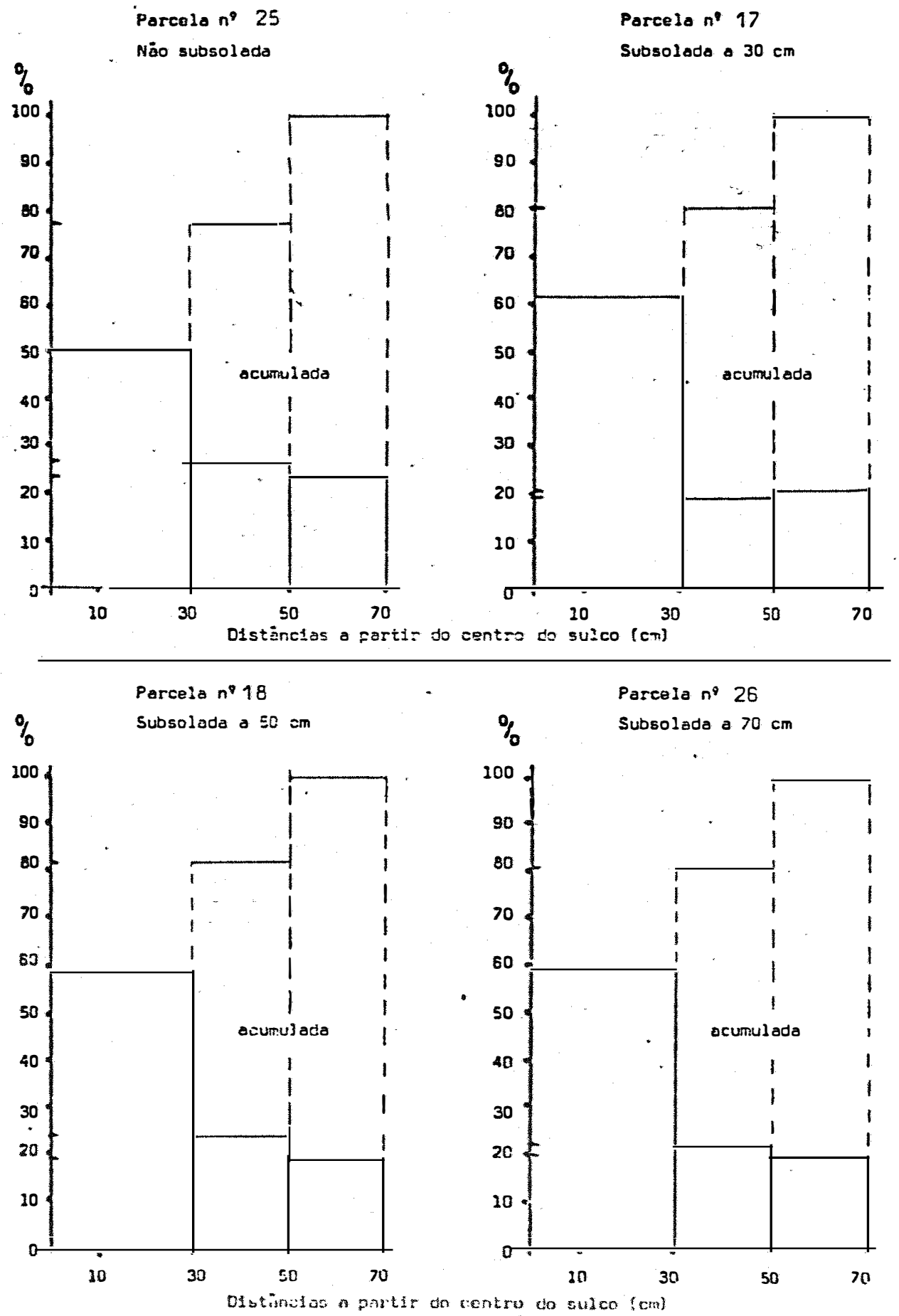

FIG. 46 - Distribuiçào porcentual acumulada das raizes no plano horizon tal dos perfls do solo, na testemunha najo súbsolada e nas par celas subsoladas, do tratamento sem compactaçào. 

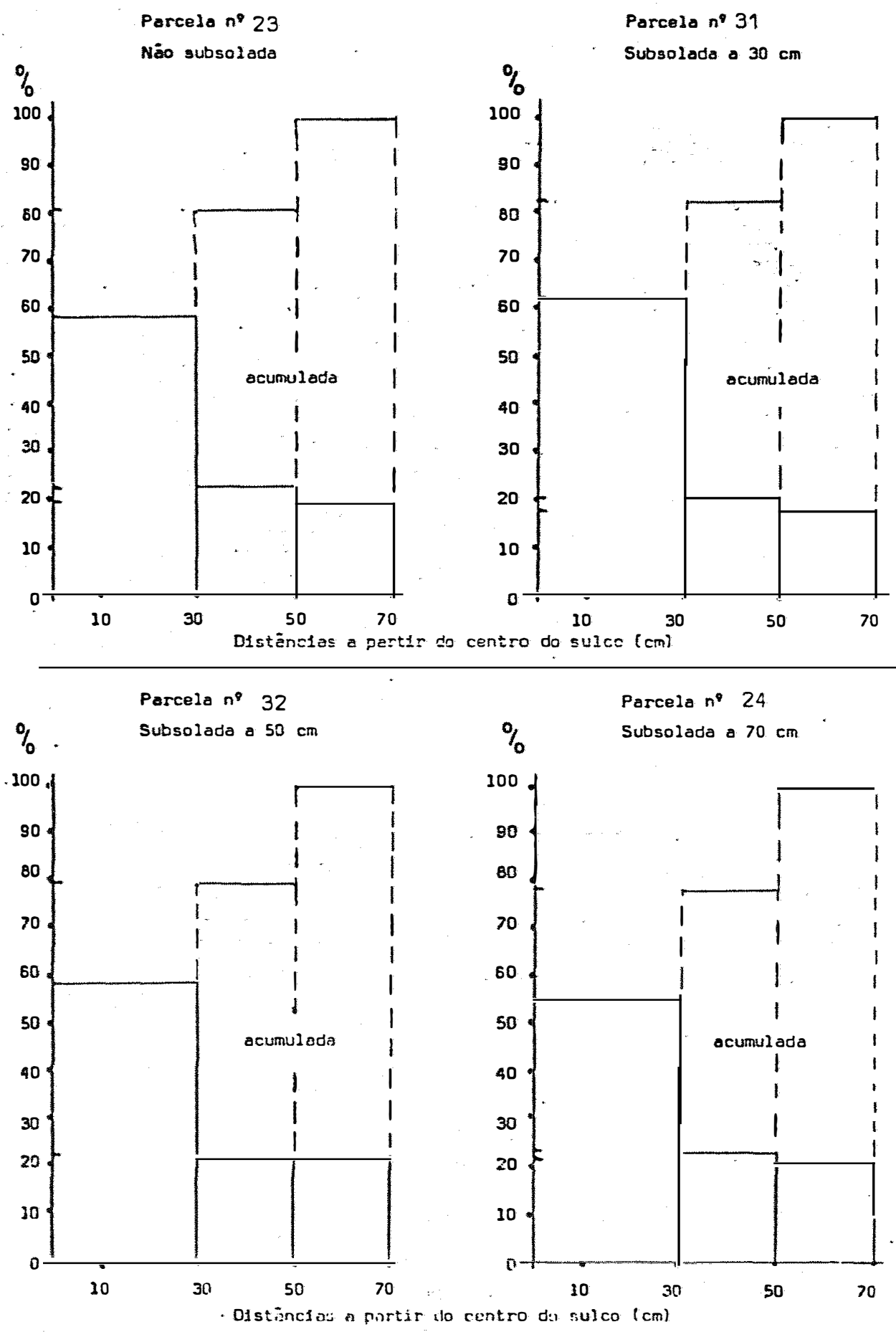

FIG. 47 - O1stribulçào porcer:tual acumulada das raízes no plano horizon tal dos perfís do solo. na testemunha nào subsolada e nas par celas subsoladas. do tratamento compactado com 1 passada do velculo. 
Parcelo ne 21

Nä́ subsol ada

$\%$

100

100

5

.

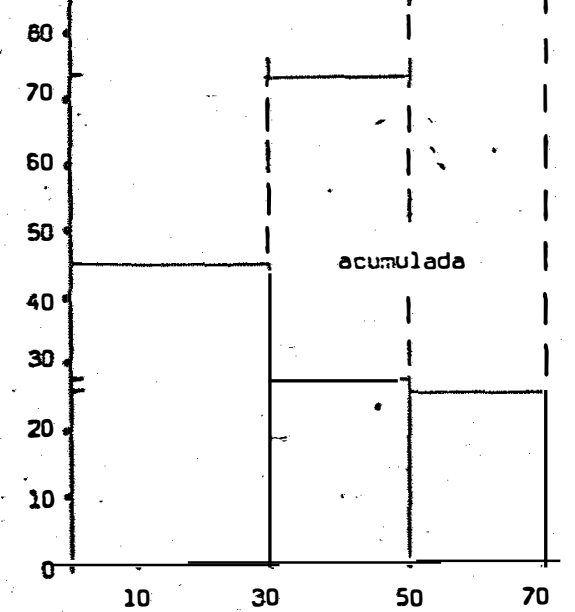

Distänclas a partir do centro do sulco $(\mathrm{cm})$

Parcela $n^{\circ} 29$

Subsolada $30 \mathrm{~cm}$

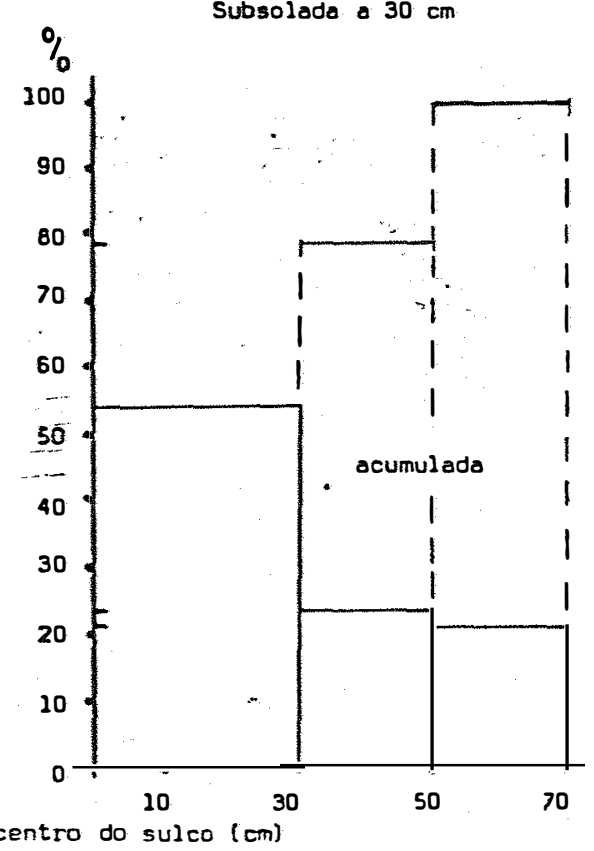

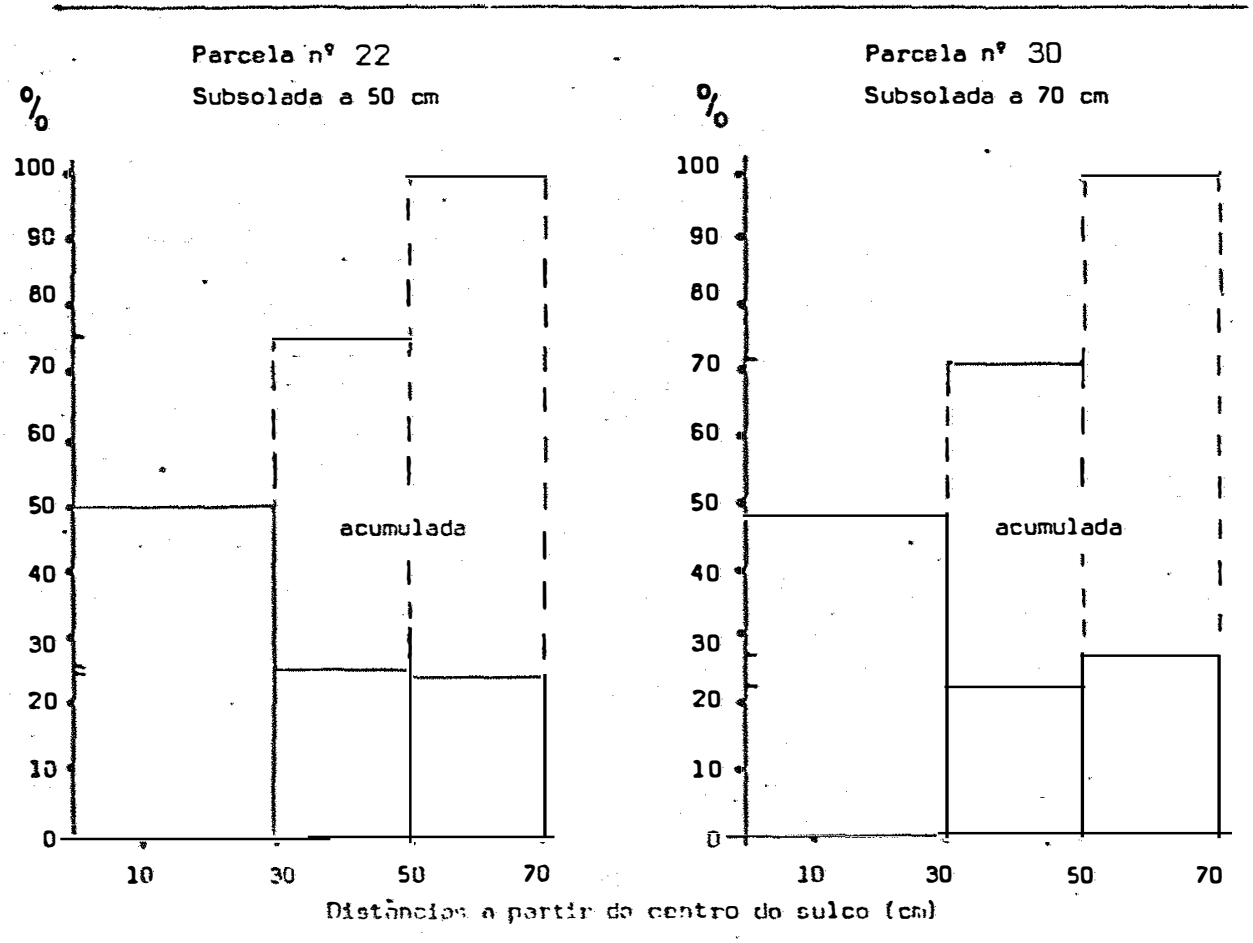

FIG. 48 - Distribulçào porcentual acumulada das raízes no plano horizon tal dos perfís do solo, na testemunha náo subsolada e nas par celas subsoladas, do tratamento compactado com 2 passadas do velculo. 


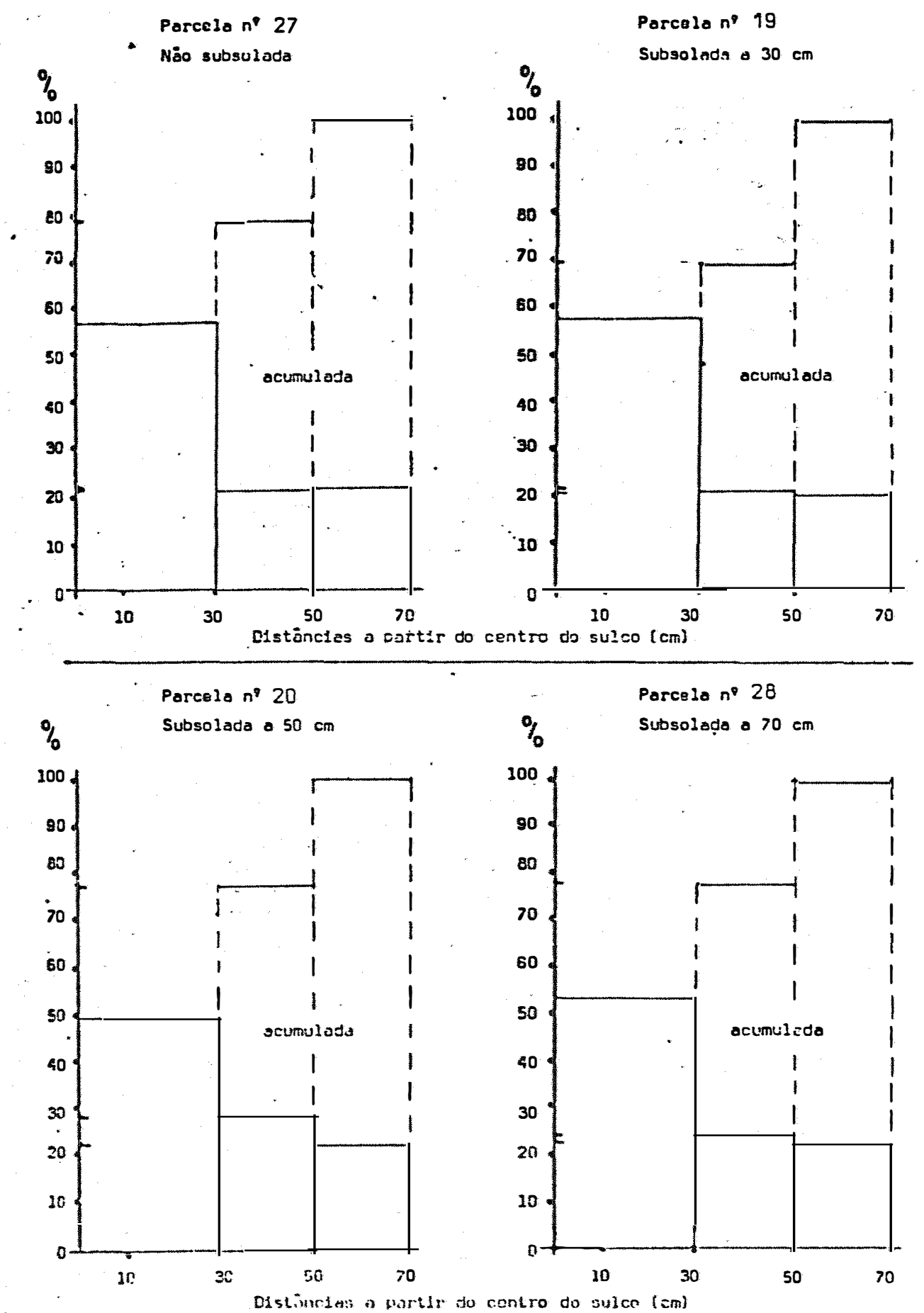

FIG. 49 - Distribulçäo porcentual acumulada das raízes no plano horizon tal dos perfís do solo, na testemuntia nào subsolada e nos par celas subsoladas, do tratamento compactado com 3 passadas do veĺculo. 

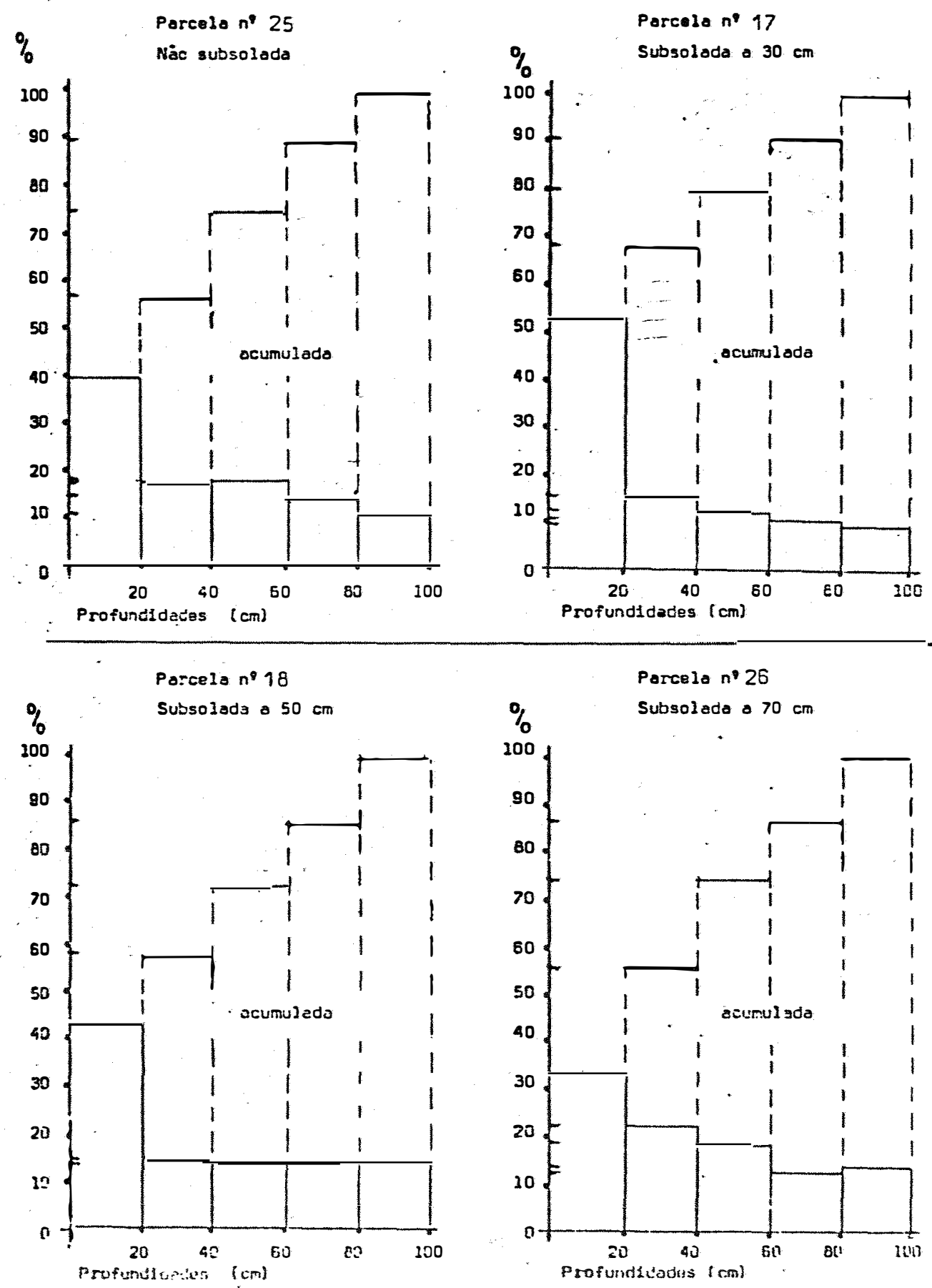

FIG. 50 - Distribulçāo porcentual acumulada das rafzes até $100 \mathrm{~cm}$ de profundidade, na testenunha nāo compactada e nas parcelas sub solades, do tratamento sem compactaçào. 

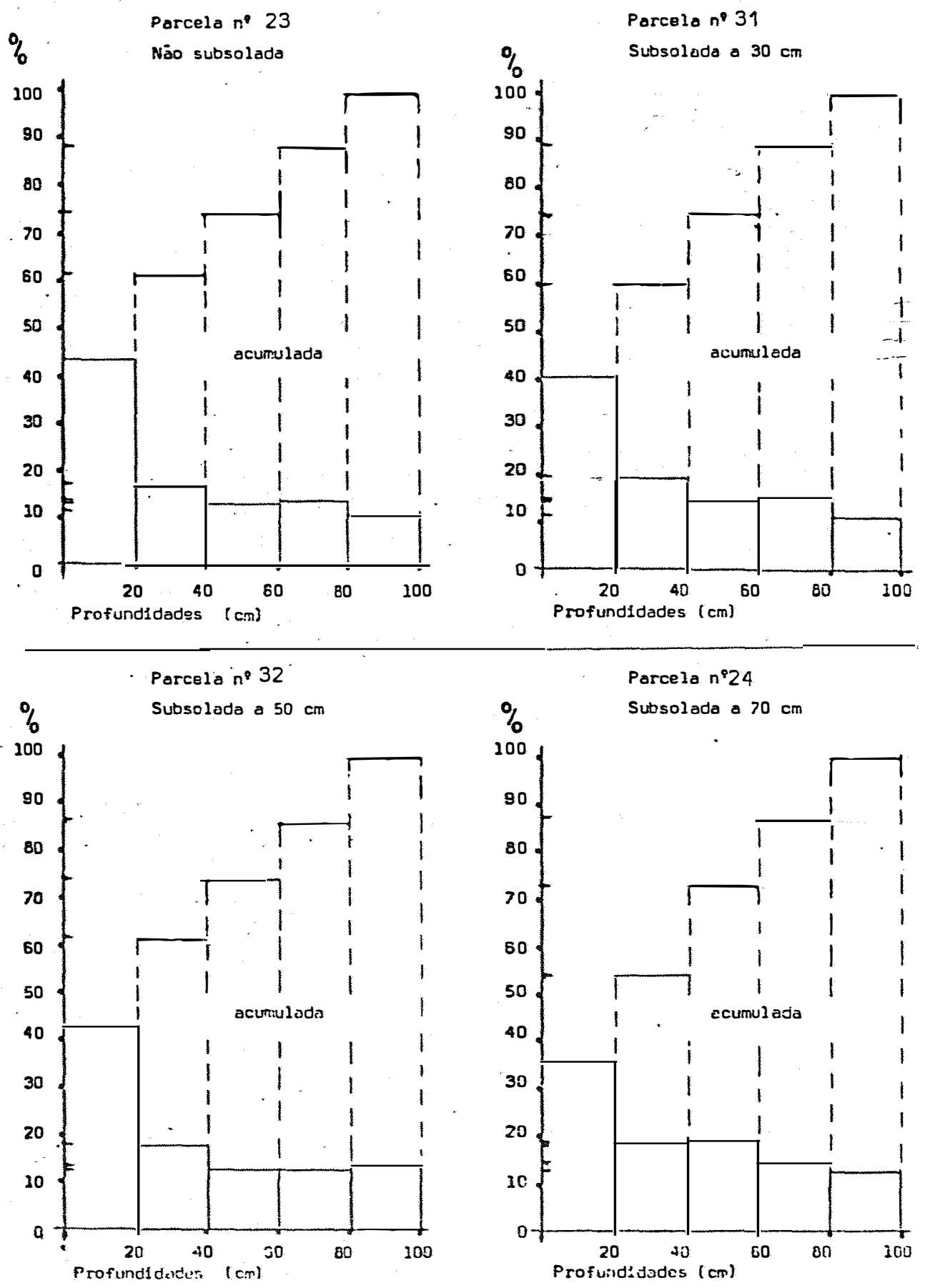

FIG. 51 - Distribulçào porcentual acumulada das rafzes até $100 \mathrm{~cm}$ de profundidade, na testemunha nào compactada e nas parcelas sub soladas, do tratamento compactado com 1 passada do velculo. 

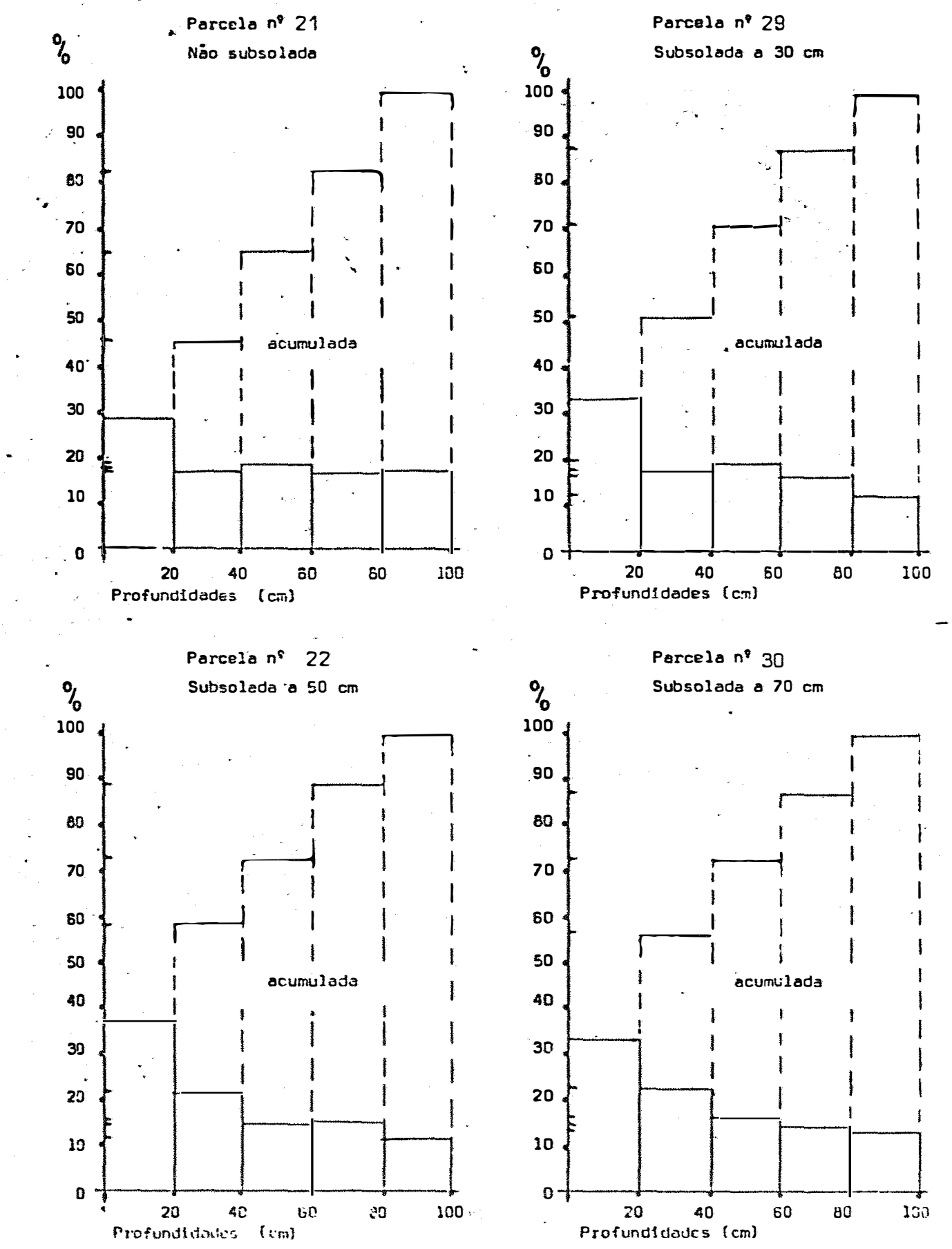

FIG. 52 - Distribulçào porcentual acumulada das raízes atè $100 \mathrm{~cm}$ de profundidade, na testemunta najo compactada e nas parcelas sub soladas, do tratamento compactado com 2 passadas do veículo." 

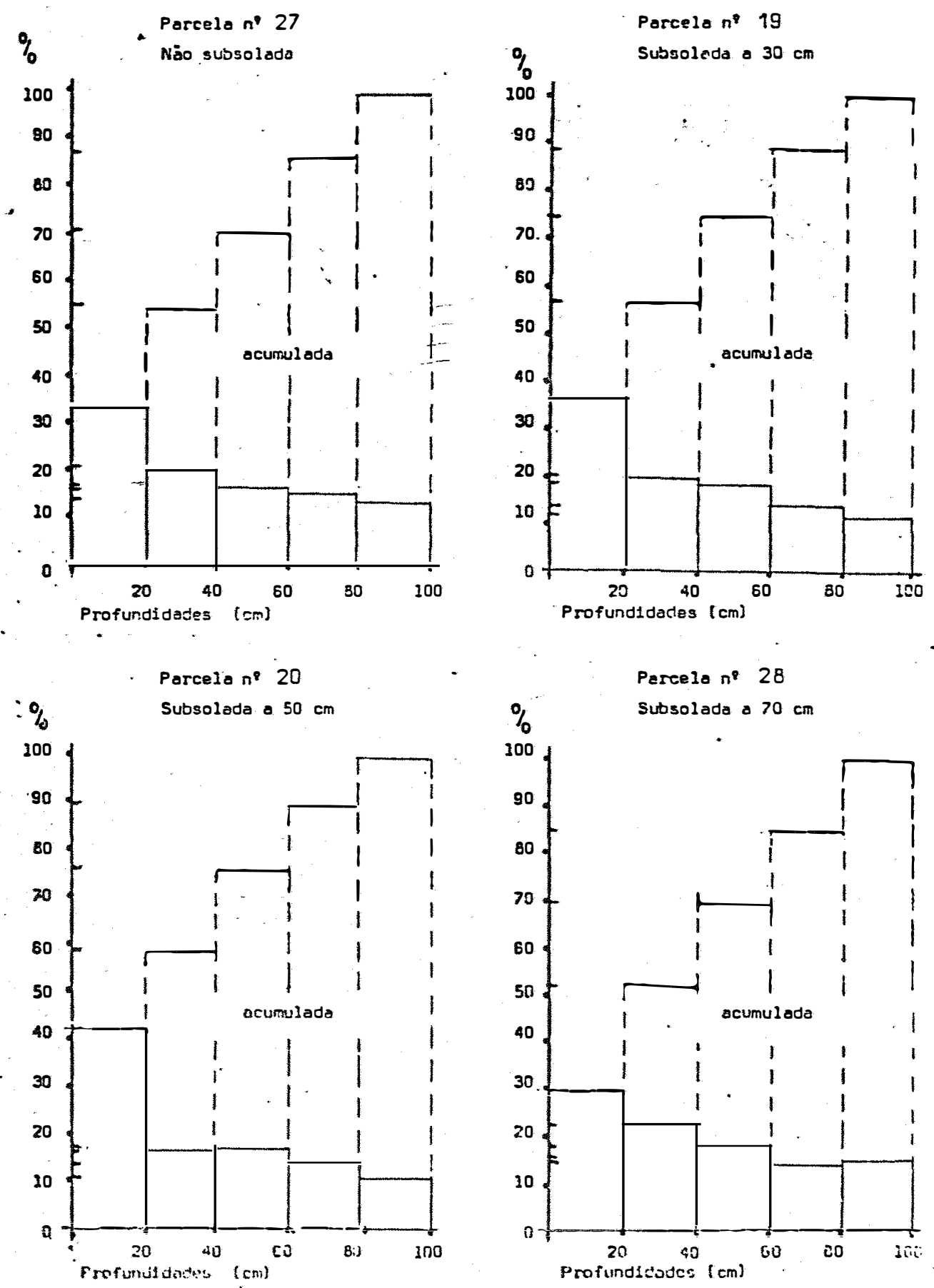

FIG. 53 - Distribulção porcentual acumulada das rafzes até $100 \mathrm{~cm}$ de profundidade. na testemunha nāo compactada e nas parcelas subsoladas, do tratamento compactado $\operatorname{com} 3$ passadas do veículo. 
TABela 42 - D1stribulçäo porcentual das ralzes no perfil do solo, cado $20 \mathrm{~cm}$ de profundidade.

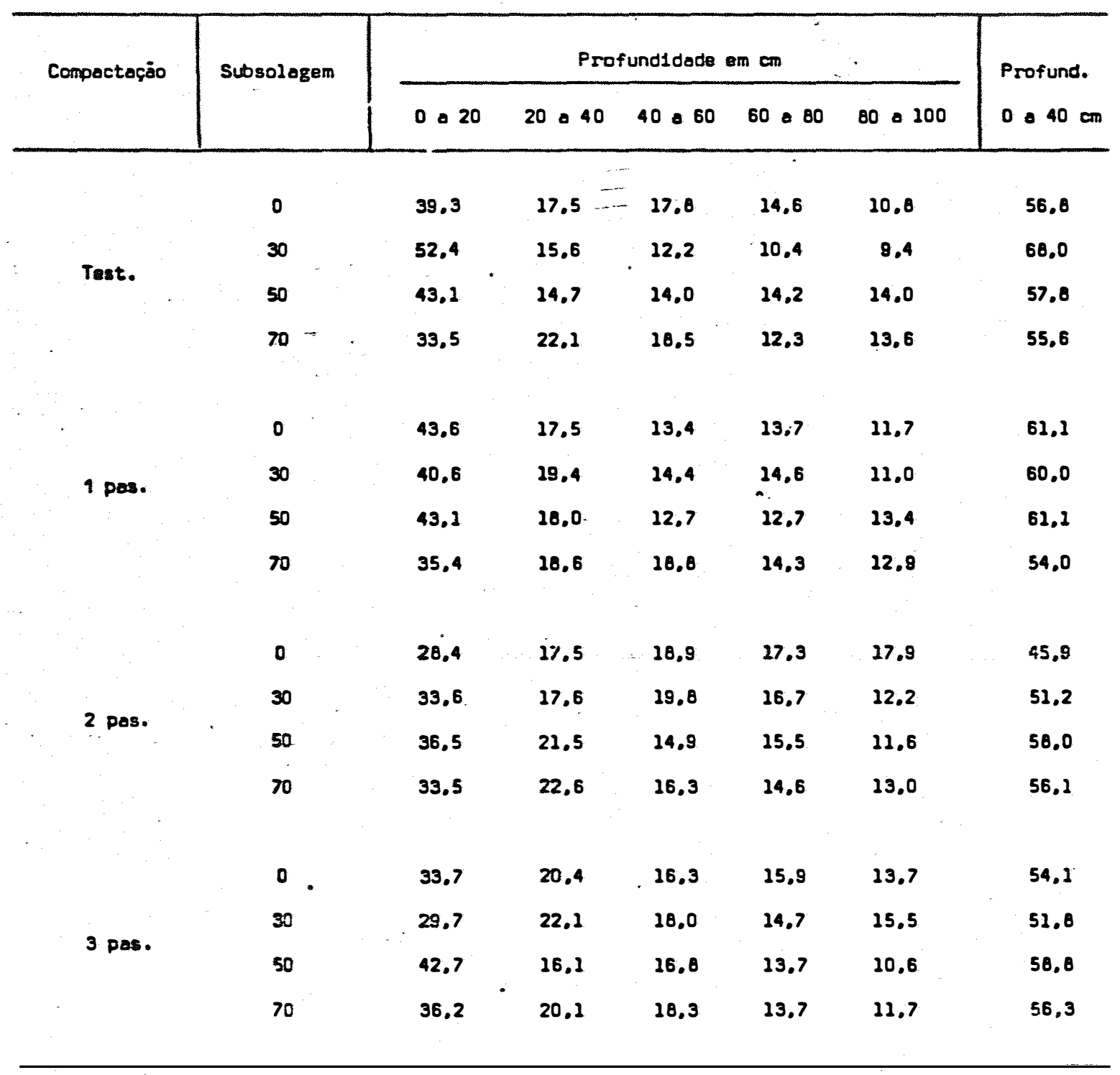




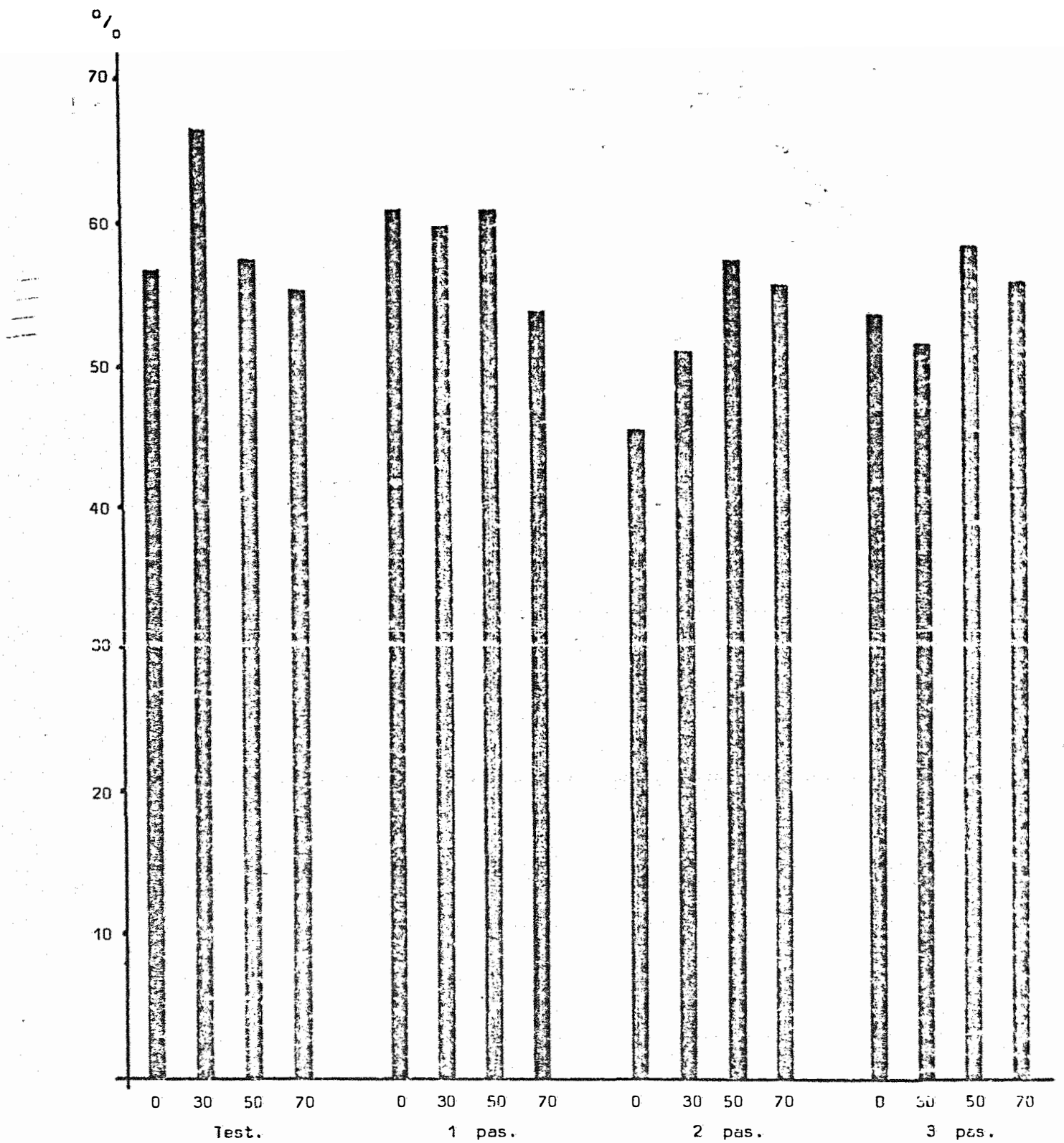

FIG. 54 - Distribuiçäo porcentual das ralzes nos $40 \mathrm{~cm}$ superficlais do solo. 
TABELA 43 - Distribulção percentual das rałzes em gramas de matéría seca a part1r dos centros dos sulcos para as entrelinhas.

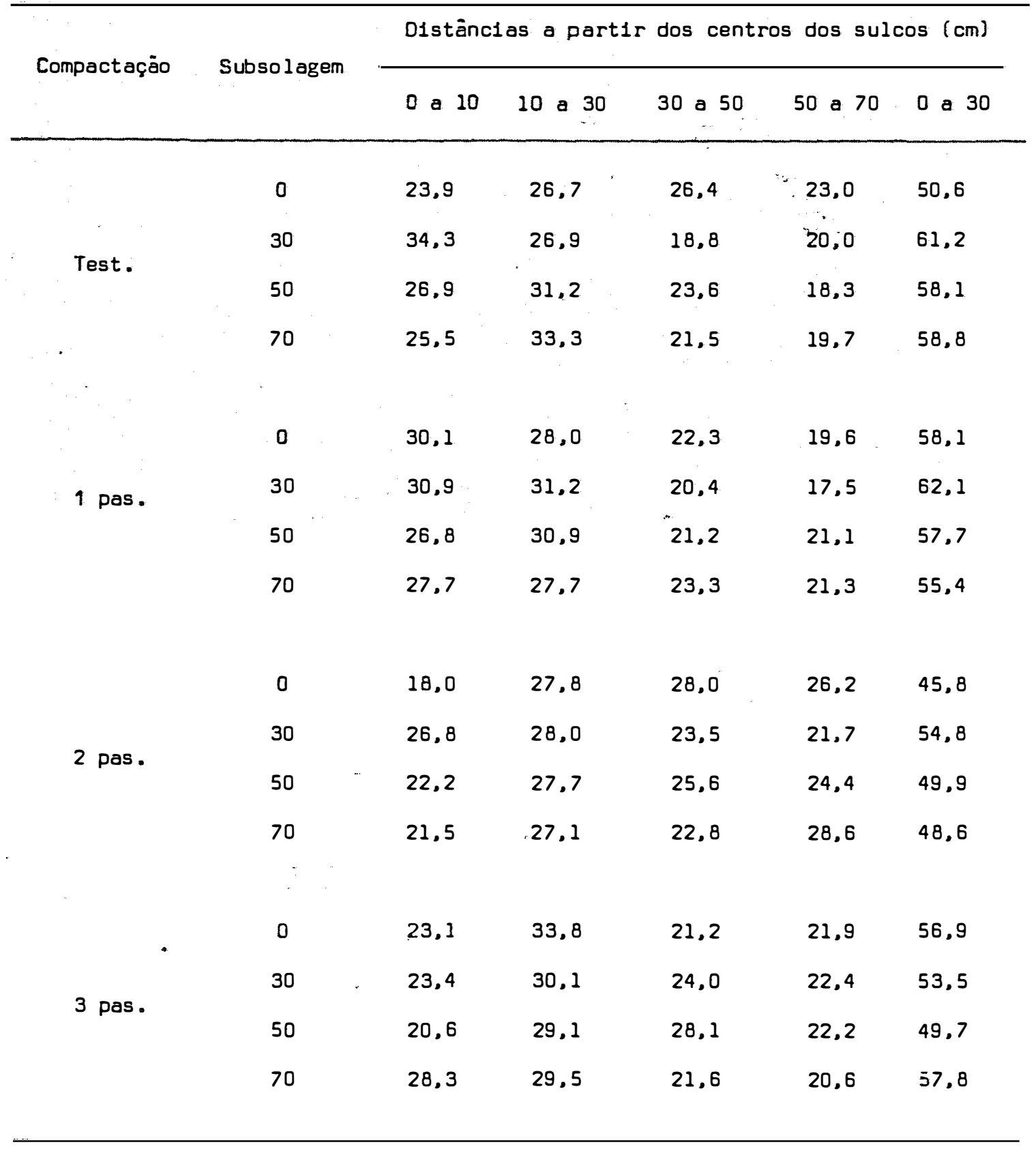




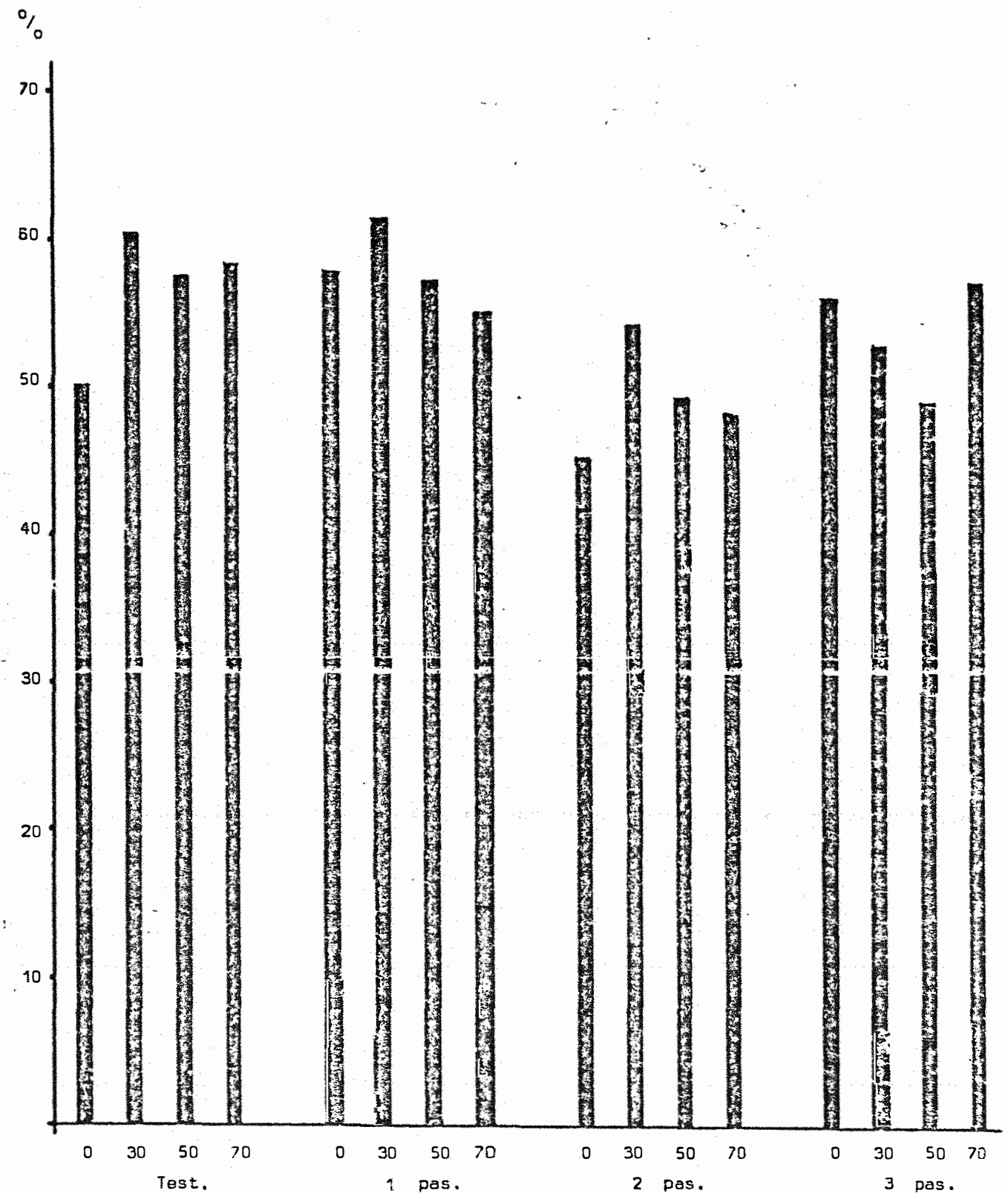

FIG. 55 - Concentração porcentlual de ralzes na falxa até $30 \mathrm{~cm}$ do centro do sulco pera a entrelinha e $100 \mathrm{~cm}$ de profundidade. 


\section{CONCLUSOES}

Para as condições sob as quais se desenvolveu - experimento, considerados os diversos fatores influentes co mo decorrência de um trabalho em regime de campo, os resulta dos obtidos permitem algumas conclusões e subsidios para no vos trabalhos nos aspectos seguintes:

\subsection{Compactação do solo}

A - Verificou-se efeito cumulativo de compactação do solo quando passado o veículo 2 e 3 vezes na mesma faixa.

B - As profundidades de máximos índices de densidade do solo variaram de $20 \mathrm{~cm}$ na testemunha não compactada para 30 $\mathrm{cm}, 30 \mathrm{~cm}$ e $35 \mathrm{~cm}$, como termos médios, quando passado o veículo 1,2 e 3 vezes, respectivamente.

C - Ds maiores índices de compactação foram observados nas entrelinhas, permitindo supor que a presença das raízes 
contribuiram para as menores densidades do solo nas faixas ocupadas pela cana.

D - Na data do corte da cana, 12 meses após as operações de compactação e subsolagem, os índices de densidade do so lo se mostraram bem mais acentuados nas parcelas não sub soladas, constatando-se os valores médios de 1,25; 1,25; 1,35 e 1,40, respectivamente, na testemunha nao compacta da e nas parcelas com 1,2 e 3 passadas

\subsection{Subsolagem}

A - O subsolador mostrou ter exercido sua influéncia descompactante em função da largura da faixa de atividade do implemento.

B - A atividade de descompactação foi constatada também nas parcelas não compactadas pelo veículo.

C - Os efeitos da subsolagem mativeram-se evidentes na for ma de mais baixos índices de densidade nas faixas de ati vidade, até a data do corte da cana.

D - Correlacionando-se as profundidades de $30-35 \mathrm{~cm}$ atingidas como pontos máximos de compactação pelo veículo, e os efeitos observados após as operações de descompactação, é de se concluir que o implemento subsolador deveria ter sido preparado para agir a uma profundidade não infe rior a $35-40 \mathrm{~cm}$.

\subsection{Sistema Radicurar}

A - As diferenças em peso das raizes não podem ser caracterizadas como sendo influenciadas pelos diferentes tratamen tos de compactação do solo.

B - Quanto à distribuição nos perfís do solo também não. fọ ram observadas acentuadas diferenças entre as distâncias das operações de subsolagem, destacando-se apenas maior 
dispersão das raízes em profundidade, na projeção das li nhas de cana das subparcelas.

C - Em termos médios as concentrações das raízes até $30 \mathrm{~cm}$ de profundidade variaram de 60 a $70 \%$ nas parcelas subso ladas, reduzindo-se para 54 a $65 \%$ nas parcelas testemunhas não subsolada.

D - Na camada até $10 \mathrm{~cm}$ de profundidadé as concentrações de raizes foram respectivamente, de 40 a $52 \%$ e de $30 \%$ a $45 \%$ nas áreas subsoladas e não subsoladas.

\subsection{Produção de Cana}

1 - As parcelas mais compactadas apresentaram maior popula ção de colmos por metro de sulco. Esse fato foi observa do logo após iniciada a brotação das soqueiras.

2 - Na data do corte porëm, os pesos por colmo verificaram-se na ordem inversa do número de passadas do veículo.

3 - Esse comportamento resultou em maiores produções finais nos tratamentos com os mais baixos índices de compactação. 


\section{SUMMARY}

Soil compaction operations were conducted in Dark Red Latossol clay phase soil, with CB41-76 variety ratooning, using sugar cane transport vehicle, traveling 1 , 2 and 3 times over the same area. Next, subsoiling was made on both sides of the sugarcane rows, at distances of 30,50 and $70 \mathrm{~cm}$ from the center of furrows, and $25 \mathrm{~cm}$ deep, using implement with wings in the lower part of the rod. Compaction cumulative effects were observed in the areas with 2 and 3 passings of vehicles. The results showed that in treatments with 1 and 2 passings of the vehicle, subsoiling at distances of 30 and $50 \mathrm{~cm}$ from furrow center was the most beneficial for the sugar cane ratoon. When the vehicle passed 3 times, there was no effect for the 3 subsoiling distances.

$$
\text { Both treatments of compaction and subsoiling - }
$$

did not show significant effects on total. root weight. Only small differences were noted in the distribution of the root system in the soil profiles. 


\section{LITERATURA CITADA}

BAVER, L.D., 1956. Physies soil. 3 rd. ed. New York, John Wiley.

CARVALHO. L.C.C. e L.R. GRAÇA, 1976. Produtividade agrícola da cana-de-açúcar no Estado de São Paulo. Brasil Açucareiro. Rio de Janeiro, 88(4):35-59.

CASAGRANDE, A.A. e O.P. GODOY, 1975. Cultivo mecánico e adu bação na soqueira da cana-de-açúcar; efeito na planta. Cientifica. Jaboticabal, 3(1):95-106.

COHRON, G.T., 1971. Forces causing soil compactions. In: BARNES, K.K., CARLETON, W.M., TAYLOR, H.M., THRDCKMDRTON, R.I. e VANDEN BERG, G.E. Org. Compaction of agricultural. soil. Michigan, ASAE, p. 106-122. 
FERRAZ, E.S. de B., 1974. Determinação simultánea de densidade e umidade de solos por atenuação de raios gama do ${ }^{137} \mathrm{Cs} \mathrm{e}^{241} \mathrm{Am}$. Piracicaba, ESALq/US'P, $120 \mathrm{p}$. (These d 'Livre-Docência).

FURLANI NETO, V.L., J. FERNANDES e L.G. MIALHE, 1978. Carac terísticas de veículos para o"transporte da cana-de-açúcar. (Trabalho apresentado no.8. Congresso Brasileiro de Engenharia Agrícola, Botucatu, SP.).

GILL, W.R., 1959. Soil compaction by traffic. Agric. Engng, $40: 392-394,400,402$. =

GILL, W.R., 1961. Mechanical impedance of plants by compact soils. Transactions of the ASAE, 4:238-242.

GILL, W.R. e G.E. VANDEN BERG, 1968. Soil dinamics in tillage and traction. Washington, USDA. $511 \mathrm{p}$.

GROHMANN, F. e H.V. de ARRUDA, 1961. Influência do preparo do solo sobre a estrutura da terra-roxa-ligitima. Bragantia. Campinas, 20(49):1203-1209.

GROHMANN, F. e J.P. QUEIROZ NETO, 1966. Efeito da compactação artificial de 2 solos limo-argilosos sobre a penetração das raízes do arroz. Bragantia. Campinas, 25(38): $421-431$.

HARRIS, W.L., 1971. The soil compaction process. In: BARNES, K.K., CARLETON, W.M., TAYLOR, H.M., THROCKMORTON, R. I. e VANDEN BERG, G.E., Org. Compaction of agricultural. soils. Michigan, ASAE, P. 9-44.

HUMBERT, R.P., 1974. El cultivo de la caña de azucar. Méxí co, Continental. $719 \mathrm{p}$. 
INFORZATO, R. e R. ALVAREZ, 1957. Distribuição do sistema radicular da cana-de-açúcar Var. Co290, em solo tipo ter ra-roxa-ligitima. Bragantia. Campinas, 16(1):1-13.

LARSON, W.E. e R.R. ALLMARAS, 1971. Management factors and natural forces as related to compaction. In: BARNES, $K$. K., CARLETON, W.M., TAYLOR, H.M., THROCKMORTON, R.I. e VANDEN BERG, G.E., Drg. Compaction of agricultural soils. Michigan, ASAE, P.367-427.

MARTINEZ, M.B. e M.A. LUGOZ-LOPEZ, 1953. Influence of subsoil shattering and fertilization on sugarcane production and soil infiltration capacity. Soil Science, 75(4):307315 .

MEADE, G.P., 1967. Manual del azúcar de caña. Barcelona, Montaner y Simon. $940 \mathrm{p}$.

MEREDITH, H.L. e W.H. PATRICK Jr., 1961. Effects of soil compaction on subsoil root penetration and physical properties of three soils in Louisiana. Agronomy Journal. $53: 163-167$.

MOBERLY, P.K., 1969. The effects on ratoon cane of subsoiling in a number of soils in the sugar belt. S. Afr. Sugar J.. $53(9): 688-689.691,693$.

NICHOLS, M.L. e C.A. REAVES, 1955. Soil structure and consis tency in tillage implement design. Agric. Engng., 36(8): $517-522$.

MONTEITH, N.H. e C.L. BANATH, 1965. The effects of soil strength on sugarcane root growth. Trop. Agr.. Trinidad, $42(4): 293-296$. 
OLIVEIRA, L.B., H.S.DANTAS, A.B. CAMPELD, S.J. GALVAO E I.F. GOMES, 1968. Caracterização de adensamento no subsolo de uma ărea de "Tabuleiro" da Estação Experimental do Curado, Recife. Pesq. agropec. bras., 3:207-214.

PASSIOURA, J.B. e G.W. LEEPER, 1963. Soil compacted and man ganese deficiency. Nature, 200(490i):29-30.

PLANALSUCAR, 1977. Relatório Anual; Estações Experimentais. Piracicaba. $100 \mathrm{p}$.

RUGAI, S. e J. ORLANDO F:, 1973. Cana-de-açūcar nos solos do Estado de São Paulo. Brasil Açucareiro. Rio de Janei ro, $82(3): 17-23$.

RICHARDS, S.J., L.V. WEEKS e J.E. WARNEKE, 1960. Comapcted bulk density and hydraulic conductivity for indicating the structural status of soils. Int. Congr. Soil Sci..Madi son, ( 7):249-255.

SHULKA, L.N. e E.J. RAVALO, 1976. Compactation del suelo en los campos de caña a causa de los carros de transporte. Sugar y Azucar, 71( 8$): 50-52$.

SoUSA, J.A.G.C., 1976. Efeito da tensão da água do solo na cultura da cana-de-açúcar (Saccharum spp). Limeira, FEL/ UNICAMP. $163 \mathrm{p}$. (Tese de Doutoramento).

TAYLOR, H.M. e E. BURNETT, 1963. Influence of soil strength on the root-growth habits of plants. Soil Science, 98:174180 .

TROUSE JT., A.C., 1967. Effects of soil compression on the development of sugarcane roots. In: CONGR. INT. SOC. SUG. TECH., 12., Puerto Rico. Proceedings. p. 137-152. 
TROUSE Jr., A.C., 1971. Soil condictions as they affect plant establishement, root development and yield. In: BAㅛ NES, K.K., CARLETON, W.M., TAYLOR, H.M., THROCKMORTON, R. I. e VANDEN BERG, G.E., Org., Compaction of agricultural. soil. Michigan, ASAE, P. 225-276.

TROUSE, Jr., A.C. e R.P. HUMBERT; 1961, Some effects of soil compaction on the development of sugarcane roots. Soil Science, $91(3): 208-217$.

TROUSE Jr., A.C. e L.D. BAVER, 1965. Tillage problems in the Hawaii-an sugar industry. III Vehicular traffic and soil compaction; tech suppl to soils. Rept. Exp. Sta. HSPA.

Van DILlewiJn, C., 1952. Botany of sugarcane. Waltham, Chronica Botanica. $371 \mathrm{p}$.

VEIHMEYER, F.J. e A.H. HENDRICKSON, 1948. Soil density and root penetration. Soil Science, 65:487-493.

VOMOCIL, J:A. e W.J. FLOCKER, 1961. Effect of soil compaction on storage and movement of soil air and water. Transctions of the ASAE, 4:242-246.

WIERSUM, L.K., 1957. The relationship of the size and struc tural rigidity of pores to the penetration by roots. Plant and Soil, $9(1): 75-85$.

YANG, S.J., 1977. Soil physical properties and the growth of rotoons cane as influenced by mechanical harvesting. In: CONGR. INT. SOC. SUG. CANE TECH., 16., São Paulo. Proceedings. p. 835-84J.

ZIMMERMAN, R.P. e L.T. KAROOS, 1961. Effect of bulk density on rotoon growth. Soil Science, 91:280-288. 


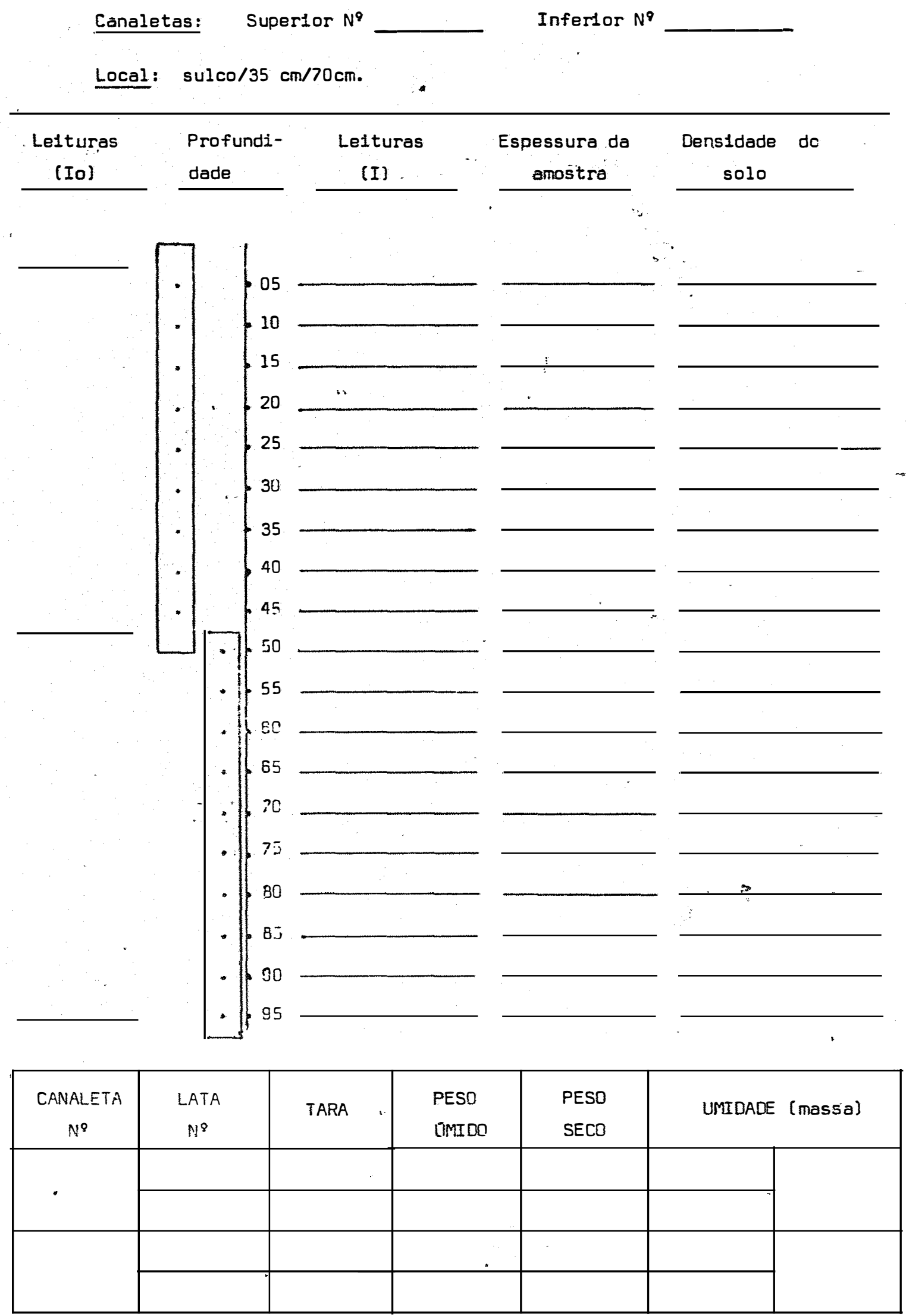

